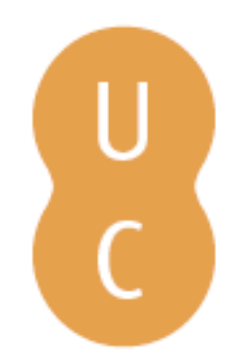

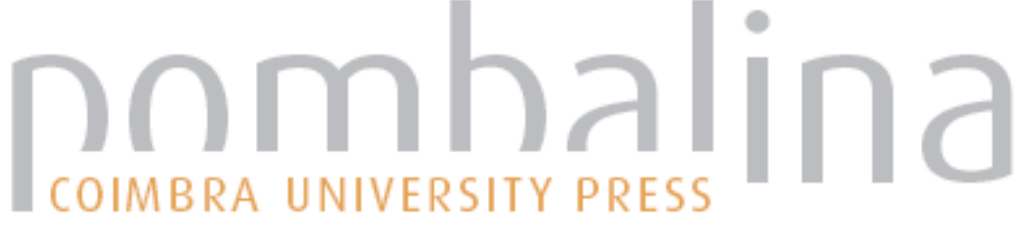

\section{Sic itur in urbem: iniciação ao Latim}

\author{
Autor(es): $\quad$ Fonseca, Carlos Alberto Louro \\ Publicado por: Imprensa da Universidade de Coimbra \\ URL \\ persistente: $\quad$ URI:http://hdl.handle.net/10316.2/38587 \\ DOI: $\quad$ DOI:http://dx.doi.org/10.14195/978-989-26-1162-4
}

Accessed : $\quad$ 26-Apr-2023 15:38:37

A navegação consulta e descarregamento dos títulos inseridos nas Bibliotecas Digitais UC Digitalis, UC Pombalina e UC Impactum, pressupõem a aceitação plena e sem reservas dos Termos e Condições de Uso destas Bibliotecas Digitais, disponíveis em https://digitalis.uc.pt/pt-pt/termos.

Conforme exposto nos referidos Termos e Condições de Uso, o descarregamento de títulos de acesso restrito requer uma licença válida de autorização devendo o utilizador aceder ao(s) documento(s) a partir de um endereço de IP da instituição detentora da supramencionada licença.

Ao utilizador é apenas permitido o descarregamento para uso pessoal, pelo que o emprego do(s) título(s) descarregado(s) para outro fim, designadamente comercial, carece de autorização do respetivo autor ou editor da obra.

Na medida em que todas as obras da UC Digitalis se encontram protegidas pelo Código do Direito de Autor e Direitos Conexos e demais legislação aplicável, toda a cópia, parcial ou total, deste documento, nos casos em que é legalmente admitida, deverá conter ou fazer-se acompanhar por este aviso.

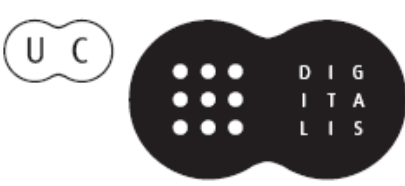




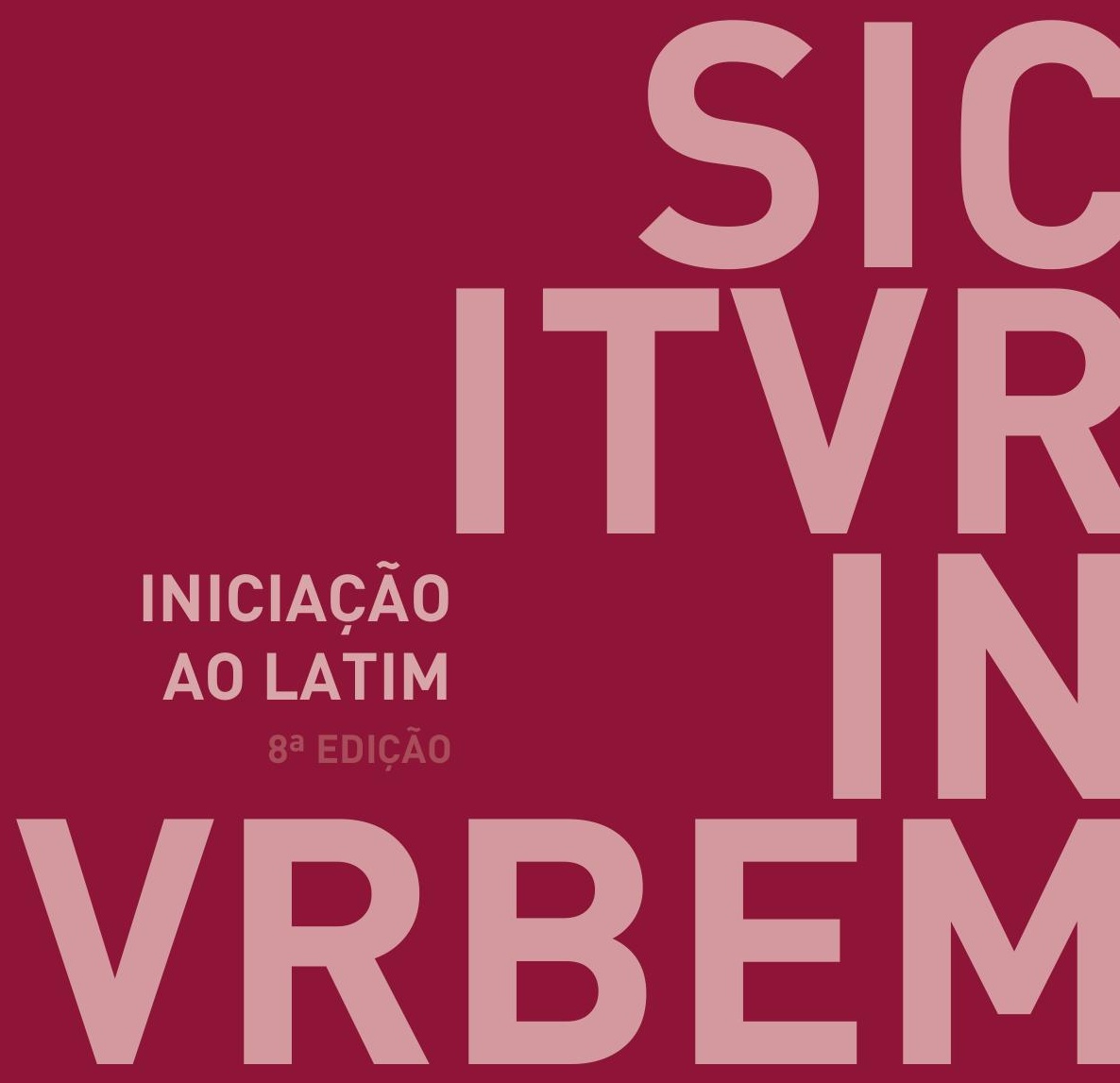

CARLOS ALBERTO LOURO FONSECA 
(Página deixada propositadamente em branco) 


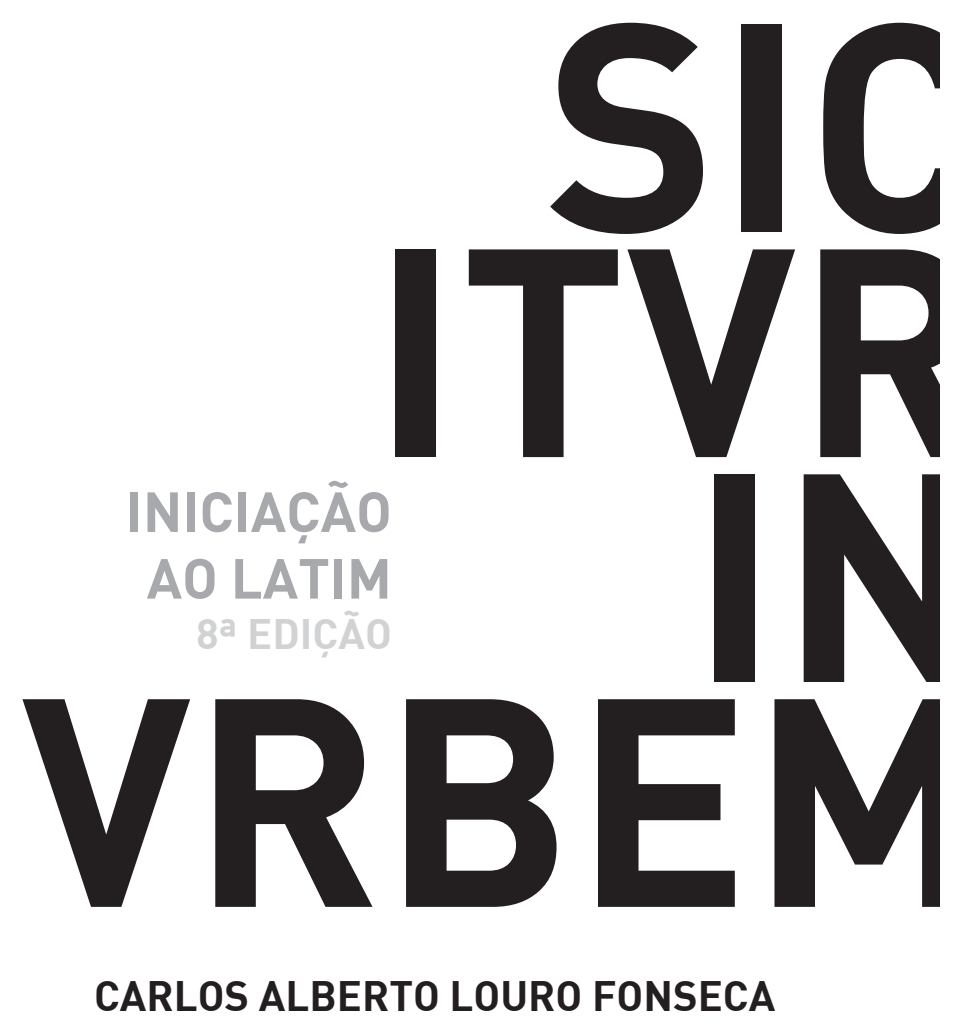

IMPRENSA DA

UNIVERSIDADE

DE COIMBRA

COIMBRA

UNIVERSI
PRESS 


\section{EDIĈ̃o}

Imprensa da Universidade de Coimbra

Email: imprensauc@ci.uc.pt

URL: http://www.uc.pt/imprensa_uc

Vendas online: http://www.livrariadaimprensa.com

\section{CONCEÇÃO GRÁFICA}

António Barros

INFOGRAFIA DA CAPA

Carlos Costa

\section{INFOGRAFIA}

Xavier Gonçalves

\section{EXECUCÃO GRÁFICA}

www.artipol.net

\section{ISBN}

978-989-26-0509-8

ISBN Digital

978-989-26-1162-4

\section{DOI}

http://dx.doi.org/10.14195/978-989-26-1162-4

\section{DEPÓSITO LEGAL}

350658/12

(C) OUTUBRO 2012

IMPRENSA DA UNIVERSIDADE DE COIMBRA

CARLOS ALBERTO LOURO FONSECA 
A necessidade de iniciar adultos no aprendizado das linguas comę̧ou nos idiomas modernos e atinge também já os antigos. Quer para uns, quer para outros, não se fez esperar o aparecimento de manuais adequados para responder a esta nova situação. Assim tem sucedido em França e em Inglaterra, com publicações para «grands débutants», que, principalmente no domínio do grego, são por vezes uma pequena obra-prima, possivel em paises com uma comprovada e sempre renovada preparação didáctica.

É um ensaio apenas o que neste livrinho apresentamos aos estudantes maiores do nosso País, com todas as limitações de quantidade e qualidade que uma primeira tentativa implica. Todo voltado à prática imediata da língua, recorrendo à imagem como auxiliar da memória e ao exercício contínuo, ora associando dados arqueológicos, ora movendo-se no contemporâneo, pretende mais fornecer sugestões para um ensino vivo e natural do que proporcionar um método rigorosamente construído. Aos mestres caberá desenvolver, ajustar, variar. Deles se espera e deseja uma crítica que contribua para o aperfeiçoamento de uma obra que a todos possa ser útil.

Coimbra, Dezembro de 1977.

Maria Helena da Rocha Pereira 
(Página deixada propositadamente em branco) 


\section{PREFACIO DA 4. ${ }^{a}$ EDIÇÃO}

Em dez anos, quatro edições de um manual para aprender Latim dizem já o suficiente da sua boa qualidade e da sua adequação às necessidades do ensino.

O Autor, porém, como todos os bons autores, não tem largado da mão a lima horaciana. Cada nova edição sai aperfeiçoada e ampliada. Esta agora divide-se em três partes, com orientação e finalidade distintas. A primeira mantém o essencial da morfologia e sintaxe, acrescentando-lhe, além de casos particulares e maior número de exemplos, uma parte muito importante sobre o conjuntivo. Os textos e exercícios de retroversão, intercalados na doutrina gramatical, aumentaram consideravelmente. A maior inovação está, todavia, na segunda parte, uma deliciosa paródia da «História Verdadeira» de Luciano, à mistura com outros hilariantes episódios (e sublinhe-se que o bom humor e a graça já afloram na seleç̧ão de "Carmina Burana» dispersos pelo corpo do livro).

$O$ perfeito dominio do Latim, que se evidencia por toda a obra, reaparece ainda na terceira parte, sob a forma de traduções a acompanhar os novos textos de Cícero e de Catulo. Estes dois autores, juntamente com Salústio e Horácio, fornecem a oportunidade para iniciar o estudante nos chamados temas de cultura. Finalmente, em apêndice, alinham-se as noções de métrica latina aplicáveis aos textos.

Uma visão da vida dos Romanos, a que não faltam pormenores arqueológicos, da sua cultura e ideais, é assim assimilada através da língua-mãe, tornada acessível graças a este método modelar.

Coimbra, Junho de 1987

Maria Helena da Rocha Pereira 
Força é que - por um simples dever de justiça e gratidão - aqui deixemos duas palavras, curtas $e$ singelas, do nosso mais profundo agradecimento.

A primeira é dirigida ao Prof. Doutor Walter de Sousa Medeiros pelo apoio, pronto e nunca recusado, que sempre nos tem concedido para a elaboração deste e de outros trabalhos. As suas sugestões e reparos muito contribuiram para que este libellum, quidquid, qualecumque tenha recebido o melhor acolhimento por parte não apenas do público, senão também da crítica.

A Imprensa de Coimbra-muito particularmente, nas pessoas dos Senhores Manuel Ferreira, Gilberto Gonçalves, António Escada, António Pires e Arménio Dinis - aqui deixamos o nosso sincero reconhecimento pela competência e gosto inegáveis, com que esta obra foi executada. A todos, o nosso cordial bem-haja!

$$
\text { C. A. L. F. }
$$


I PARTE 



\section{INTRODUÇÃO}

\section{A PRONÚNCIA RESTAURADA DO LATIM \\ (aspectos principais)}

\section{Vogais:}

- o sinal $v$ colocado sobre uma vogal indica que ela é breve;

- o sinal - colocado sobre uma vogal indica que ela é longa;

- o sinal c colocado sob uma vogal indica que ela é aberta;

- o sinal o colocado sob uma vogal indica que ela é fechada.

Assim :

$\breve{\mathrm{e}}=\mathrm{e}$ (como port. leve): lat. lěuis leve; lat. Rĕmus Remo (nome próprio);

$\overline{\mathrm{e}}=\mathrm{e}$ (como port. ledo): lat. lēuis liso; lat. rēmus remo;

$\check{\delta}=\mathrm{Q}$ (como port. pó): lat. pópŭlus povo; lat. sŏlum chão, solo;

$\overline{\mathbf{o}}=\mathbf{o}$ (como port. todo): lat. pốpŭlus choupo; lat. sōlum somente.

N. B. :

$\check{\mathbf{y}}, \overline{\mathbf{y}}=u$ francês em palavras como sur, mur: lat. dy̆nástēs príncipe; lat. ly̆ra lira; lat. Pýthia Pítia ou Pitonisa.

\section{Ditongos:}

ae $=$ ai $($ como port. pai): lat. caelum céu; lat. Caelius Célio;

$\mathbf{o e}=$ ói (como port. dói $):$ lat. poena castigo; lat. Poeni Cartagineses. 
Semivogais: en algumas edições escolares, representadas por $\mathbf{j}$ e $\mathbf{v}$ : estas grafias não devem ser usadas.

I, i: iam já, Áiax Ájax, máior maior;

V, u: uenit vem, ōuum ovo, uult quer, uita vida, Vēróna Verona.

\section{Consoantes:}

c : sempre com o valor de oclusiva velar surda: cacúmen cume, caecus cego, cécǐdi caí, Cícěrō Cícero.

g : sempre com o valor de oclusiva velar sonora: gábălus instrumento de tortura, gaesa dardos, gélĭdus gelado, ēgi conduzi, Vergílius Virgílio.

N.B.:

Nas abreviaturas dos nomes próprios, o $\mathrm{C}$ deve ser lido como G:

C. = Gaius Gaio, Cn. = Gnaeus Gneu.

$\mathbf{h}$ : pronunciado como o $h$ em inglês (high, hot, etc.):

homō homem, hic este, reprehéndĕre censurar, Homếrus Homero.

N.B.:

As consoantes aspiradas devem ser pronunciadas como uma oclusiva surda seguida de aspiração. Assim:

$$
\begin{aligned}
& \text { ph }=\mathrm{p}-\mathrm{h} \text { (como em inglês uphill) } \\
& \text { th }=\mathrm{t}-\mathrm{h}(" \text { " } " \text { anthill }) \\
& \text { ch }=\mathrm{c}-\mathrm{h}(" \text { " } " \text { packhorse })
\end{aligned}
$$

Exemplos: philósð̌phus, Philíppus, thěátrum, Theodōrus, chorus, Chaldäe. 
m e $\mathbf{n}$ : nunca nasalizam as vogais precedentes:

$$
\begin{array}{ll}
\text { rosam (= rosa-m) } & \text { Antōnius (= A-n-tōnius) } \\
\text { rēgem }(=\text { rēge-m) } & \text { nōmen (= nōme-n) }
\end{array}
$$

s : é sempre pronunciado como sibilante surda: semper sempre, causa causa, dómĭnus senhor, Caesar César.

t : é sempre pronunciado como oclusiva dental surda: rátiō cálculo, áctiō acção, hostis inimigo, Palátium (monte) Palatino (em Roma), amat ama, sunt são (eles).

$\mathbf{x}$ : é sempre pronunciado como consoante dupla (cs):

Xerxēs Xerxes (rei dos Persas), exérchtus exército, lēx lei.

\section{PRONÚNCIA DAS CONSOANTES GEMINADAS}

Os grupos constituídos por consoantes geminadas tinham, em latim, uma pronúncia semelhante à que hoje se verifica em italiano com as chamadas doppie. Desse facto, temos uma prova evidente em português. Assim, enquanto as consoantes simples intervocálicas estavam sujeitas a alterações várias na sua evolução para a nossa língua, as consoantes geminadas mantiveram-se, embora reduzidas a simples. Exemplos:

$$
\begin{aligned}
& \text { ripa - > riba } \\
& \text { habēre }>\text { haver } \\
& \text { mutu }->\text { mudo } \\
& \text { pede }->\text { pé } \\
& \text { pacāre }>\text { pagar } \\
& \text { filu - }>\text { fio } \\
& \text { lana - > lã }
\end{aligned}
$$

$$
\begin{array}{ll}
\text { cappa - } & >\text { capa } \\
\text { abbāte - } & >\text { abade } \\
\text { cattu - } & >\text { gato } \\
\text { amiddŭla }- & >\text { amêndoa } \\
\text { bucca - } & >\text { boca } \\
\text { capillu - } & >\text { cabelo } \\
\text { canna - } & >\text { cana }
\end{array}
$$




\section{EXERCÍCIO DE LEITURA}

Si quid est in mē ingéni, iúdicēs, quod séntiō quam sit Se eu tenho algum talento, ó juizes, o qual bem vejo como é exíguum, aut si qua exercitátiō dicéndi, in qua mē nōn infítior escasso, ou alguma prática da oratória, na qual não nego que mediócriter esse uersátum, aut si huiúsce rei rátiō áliqua sou medianamente versado, ou, ainda, algum conhecimento teórico des-

ab optimárum ártium stúdiis ac disciplína prōfécta, a qua ta matéria, derivado do estudo sistemático das artes liberais, do qual, ego nullum confíteor aetátis meae tempus abhorruísse, confesso, me não afastei em época alguma da minha vida, de tudo isso eárum rērum ómnium uel in primis hic Aulus Licínius é Aulo Licinio, aqui presente, quem deve, porventura mais do que fructum a mē repétere prope suō iure dēbet. Nam quoad ninguém, reclamar os frutos, quase por direito próprio. Com efeito, longíssimē potest mēns mea respícere spátium praetériti até onde a minha memória pode rever a tempo passado e recordar o témporis et puerítiae memóriam recordári últimam, inde mais distante periodo da minha infância, eu vejo, relembrando os facusque répetēns hunc uídeō mihi príncipem et ad suscitos desde então, que este meu constituinte foi quem mais concorreu, piéndam et ad ingrediéndam ratiốnem hōrum studiốrum não apenas para eu empreender, senão também para eu me iniciar neste exstitísse.

género de estudos.

(Cícero, Prō Árchia poēta, I, 1) 


\section{ACENTUAÇÃO}

Em latim não se empregavam sinais gráficos especiais para indicar a natureza ou a posição do acento. $O$ acento agudo usado nas primeiras liçoes deste livro, bem como os sinais - (vogal longa) e $\checkmark$ (vogal breve), destinam-se apenas a facilitar a leitura.

Regra de acentuação:

a) Pictû́ra:

b) Fábǔla:

Outros exemplos:

a) arēna arena; areia culina cozinha

illaesus ileso

Centaurus Centauro

cauerna gruta

magistra mestra

taberna loja

N.B.:

As sílabas podem ser longas ou breves. É longa a que contém uma vogal longa por natureza ou um ditongo ou uma vogal breve seguida de duas consoantes ou de uma consoante dupla $(\mathbf{z} ; \mathbf{x}$ : psalmizō 'eu canto salmos'; exxistímō 'eu considero').

b) amphorra ânfora discipŭla discípula audacia coragem ianŭa porta iniurĭa injustiça N.B.:

Uma vogal seguida de outra vogal é geralmente breve. 
EXERCÍCIO DE LEITURA:

\section{Imperium Rőmånum}

Rōma in Italǐa est. Italĭa in Euröpa est. Graecĭa in Eurōpa est. Italǐa et Graeč̌a in Eurōpa sunt. Hispanǐa in Eurōpa est. Hispanǐa et Italĭa et Graecĭa in Eurōpa sunt. Gallĭa et Germanĭa in Eurōpa quoque sunt.

Aegyptus in Eurōpa nōn est: Aegyptus in Afrǐca est. Syrră nōn est in Eurōpa, sed in Asĭa. Carthāgō in Afrǐca erat.

Imperĭum Rōmānum fuit magnum. Mediterraněum mare in medīō Imperīō Rōmānō erat: qua dē causa Mediterraněum mare lacus Rōmānus fuit.

PRIMEIRA DECLINAÇÃO: FEMININOS e masculinos

\begin{tabular}{|c|c|c|}
\hline Singular & & Plural \\
\hline Nominativo: & $-a ̆$ & $-a e$ \\
\hline Vocativo: & $-\breve{a}$ & $-a e$ \\
\hline Acusativo: & -ăm & -ās \\
\hline Genitivo: & $-a e$ & -ārum \\
\hline Dativo: & -ae & -ĩs \\
\hline Ablativo: & $-\bar{a}$ & -ĩs \\
\hline
\end{tabular}

Exemplos:

Feminino: insŭla, ae $a$ ilha

Masculino: poēta, ae o poeta

\section{Singular}

N. insŭlă

V. insǔl $\breve{a}$

Ac. insŭlăm

G. insǔlae

D. insŭlae

Ab. insǔla $\bar{a}$
Plural

N. insŭlae

V. insŭlae

Ac. insǔlās

G. insulārum

D. insŭlis

Ab. insǔlis 

N. poèta
N.
V.
V.
Ac.
Ac.
G.
G.
D.
D.

Ab.

Ab.

Decline:

$\begin{array}{ll}\text { cella, ae 'quarto pequeno' } & \text { ōra, ae 'litoral' } \\ \text { epistŭla, ae 'carta' } & \text { puella, ae 'menina' } \\ \text { era, ae 'patroa' } & \text { rēgina, ae 'rainha' } \\ \text { fera, ae 'animal feroz' } & \text { silua, ae 'floresta; mata' } \\ \text { flamma, ae 'chama' } & \text { superbia, ae 'orgulho; arrogância' } \\ \text { lacrima, ae 'lágrima' } & \text { uia, ae 'estrada; rua' }\end{array}$

N.B.:

1. Os nomes da $1 .^{\mathrm{a}}$ declinação são, na sua grande maioria, FEMININOS.

2. São masculinos, apenas, os nomes de homens, ou os que se referem às suas ocupações, como por exemplo:

Catilina: Catilina

aduěna: o estrangeiro

agricŏla: o agricultor collēga: o companheiro

nauta: o marinheiro

scriba: o copista; o escriba

\section{Declinação grega :}

N. Aenēās Eneias (herói troiano)

V. Aenēā

Ac. Aenēam

G. Aenēae

N.B.:

D. Aenēae

Os nomes próprios da $1 .^{\mathrm{a}} \mathrm{decl}$. imAb. Aenēā portados do grego diferem da declinação de insula no nominativo do singular.

A desinência -s deste caso explica-se pelo facto de, em grego, os masculinos correspondentes terminarem em sigma $(=\mathrm{s})$. 


\section{OBSERVAÇÃo}

Há palavras, nesta declinação, que só se usam no plural, como por exemplo: diuitiae, diuitiārum 'riqueza(s)', Athēnae, ärum 'Atenas', Syracūsae, ārum 'Siracusa'. Outras, como gratiae, gratiārum 'agradecimento(s)', podem apresentar um significado diferente no plural. Assim:

cōpia, ae abundância

gratia, ae benevolência

littěra, ae letra (do alfabeto) cōpiae, ārum tropas

gratiae, ārum agradecimento $(s)$

litterae, ārum carta; literatura

\section{ADJECTIVOS :}

\section{Singular}

N. magna cōp̆a uma grande abundância

V.

Ac.

G.

D.

Ab.

\section{Plural}

N. cōpiaae

$\mathrm{V}$. cōprae

Ac. cōpīās

G. cōpiārum

D. cōplīs

Ab. cōpris

\section{Singular}

N. fēmìna Graeca a mulher grega

V.

Ac.

G.

D.

Ab.

\section{Plural \\ $\mathrm{N}$. \\ V. \\ Ac. \\ G. \\ D.}

Ab. 
Decline:

mēnsa alta 'mesa alta' uita laeta 'vida alegre'

terra sicca 'terra seca'

culina ampla 'cozinha espaçosa'

discipũla bona 'boa aluna'

aqua turbìda 'água turva'

cella uinaria 'adega'

uia ardua 'caminho difícil'

\section{FUNÇÃO DOS CASOS:}

Nominativo: Magistra est bona:

Vocativo: Magistra, tu es bona:

Acusativo: Discipŭla amat magistram:

Genitivo: Villa agricŏlae est magna:

Dativo: Serua epistŭlam erae dat (entrega):

Ablativo: $\quad$ Magistra amatur (é amada) $\bar{a}$ discipŭlā:

Magistra est in scholā cum discipülā: 
EXERCíCIOS :

I - Ara sacra 'altar sagrado':

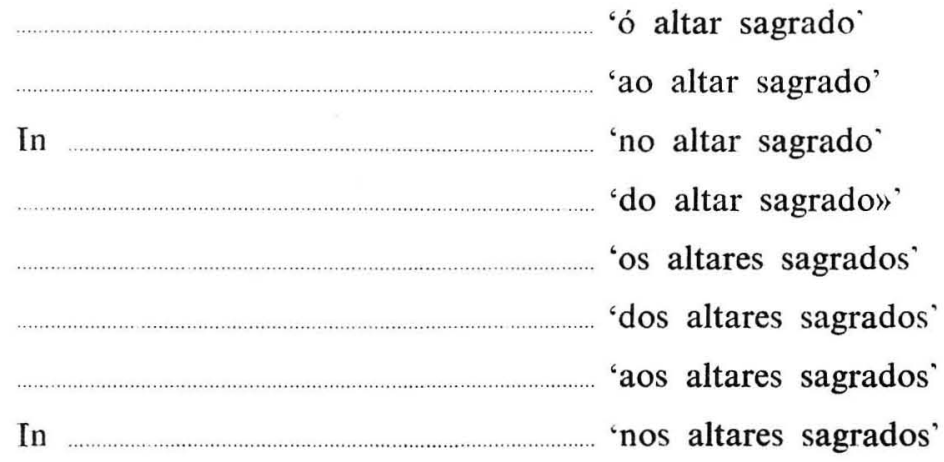

II - Iulia est puella.

Iulia et Paula sunt puell

Caecilia, es bona!

Caecilia et Aemilia, estis bon

Vrsŭla et Augusta sunt discipŭlae.

Vrsula et Augusta sunt in schola $\bar{a}$ cum magistr

Magistra narrat fabŭlam Vrsulae et Augustae.

Magistra fabulam narrat discipul.

Cypria (Cípria $=$ Vénus) erat dea.

Discipulae amant fabulas dē (acerca de) deā Cypri.

Aenēas filius (filho) Cypriae erat.

Cypria erat mater (mãe) Aenē.

III - Vbi (onde) sunt Vrsǔla et Augusta?

Quid (que coisa; o que é que) magistra discipulis narrat?

Quis (quem) erat Aenēas? 


\section{IV - Paula et Iulia}

Paula est puella Lusi-

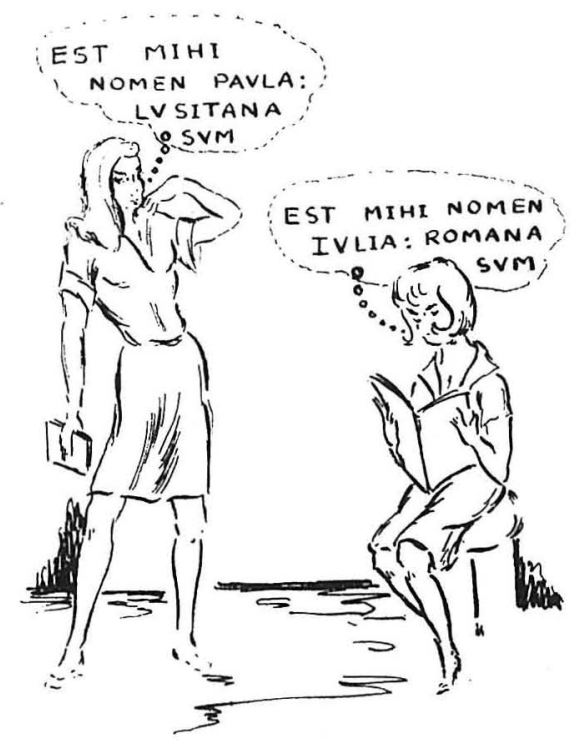

Paulam. Paula et Iulia

amicae sunt. Paulae familiă habet (tem) magnam uillam

(casa de campo) apud (junto de; nos arredores de) Conim-

brigam (Condeixa). Paula et Iulia iucundam (agradável)

uitam agunt (levam; passam); nam (com efeito) fēriae sunt.

Puellae autem (porém) pigrae (preguiçosas) nōn sunt: maně

(de manhã) enim (na verdade) puellae linguam Latinam dis- 
cunt (aprendem; estudam); post (depois de) prandium (almoço)

ludunt (brincam).

V - Paula e Júlia são amigas. Paula é portuguesa e mora numa (habitat + acusat.) grande casa de campo perto de

Condeixa. Júlia é de Roma (= romana). Paula escreve (scribit) uma carta e convida Júlia para (convida para: inuitat in + acusat.) [sua] casa: é que são férias.

Júlia vem (uenit) a Portugal: apesar de (quamuis) rapariga da cidade (urbana, ae), gosta da vida do campo (rustĭca, ae). Por isso (Qū̄ dē causā) observa atentamente (attentē spectat) as vacas (uacca, ae), as galinhas (gallina, ae) e os agricultores a cultivarem (colentēs) a terra. 
Paula e Júlia levam uma vida agradável. As meninas, porém, brincam e estudam latim. É que Paula e Júlia gostam de histórias (fabǔla, ae) acerca de Roma. Por isso, a professora conta belas (pulchra, ae) histórias às meninas: «Uma vez (Ōlim), Eneias, filho de Vénus (= da deusa Cípria), navegava (nauigābat) para (in + acusat.) Itália...» Paula e Júlia estão felizes (laeta, ae): que (quam) bela é a história de Eneias!

VI - Athēnae sunt pulchrae.

Syracūsae in ōris Siciliae sunt.

Scripsi (escrevi) magnas littĕras.

Cōpiae Rōmanae Alpēs transiērunt (atravessaram).

Diuitiae saepe (muitas vezes) causa superbiae sunt. 


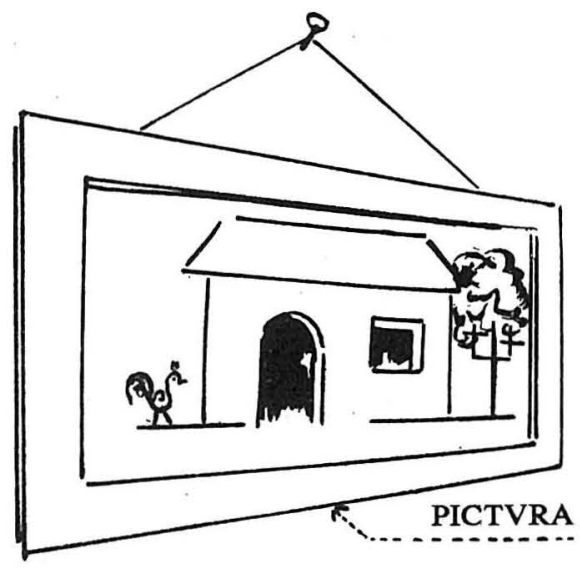

ORDEM DAS PALAVRAS NA FRASE LATINA:

Villă est in pictūrā.

Est uilla in pictura.

Est in pictura uilla.

In pictura est uilla.

In pictura uilla est.

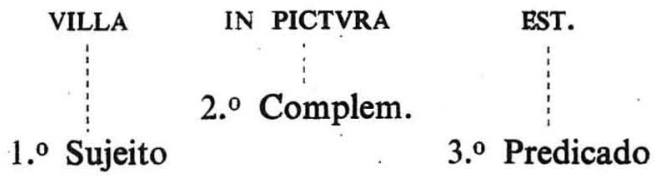

\section{Lusitania, patria nostra}

Lusitania nostra patria est. Habitāmus pulchram terram, ubi natūra splendĭda est, sed nōn semper fēcunda. Lusitaniae agricŏlae terram amant et magnā industriā contra miseriam pugnant. Nunc in Lusitania uita satis serēna est et aduěnae, qui nostram patriam uiš̌tant, laudant natūrae et ōrārum dēlicias. 


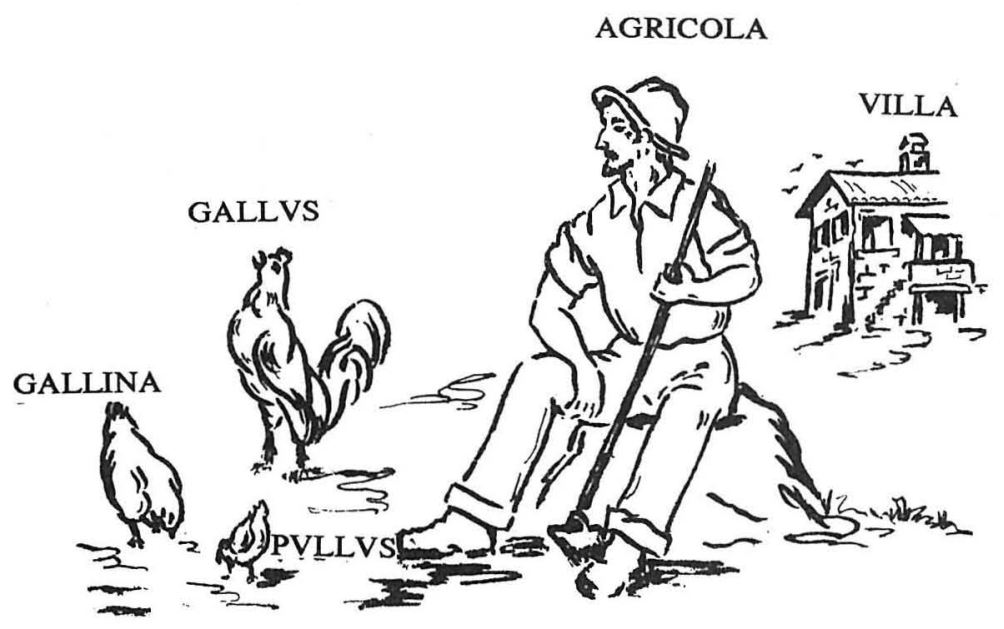

Hic (este) uir (homem) est agricŏla.

Agricola est uir qui agrōs (campos) colit (cultiva).

Agricola uitam rustǐcam amat.

Hŏc (este) aedificium est uilla.

Haec (esta) uilla nōn est magna.

Villa est aedificium in agris exstructum (construido).

Gallus, gallina et pullus in agrō sunt.

Gallus cantat; gallina et pullus ēscam (ēsca, ae comida) quaerunt (procuram). 
COMPLEMENTOS DE LUGAR

a) Agricǒla est in uillā.

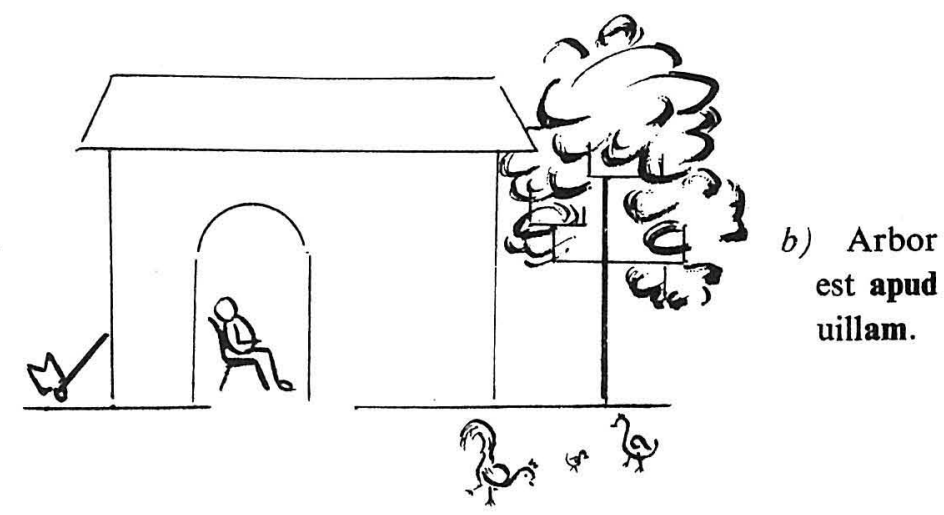

c) Gallus, gallina et pullus sunt circa uillam.
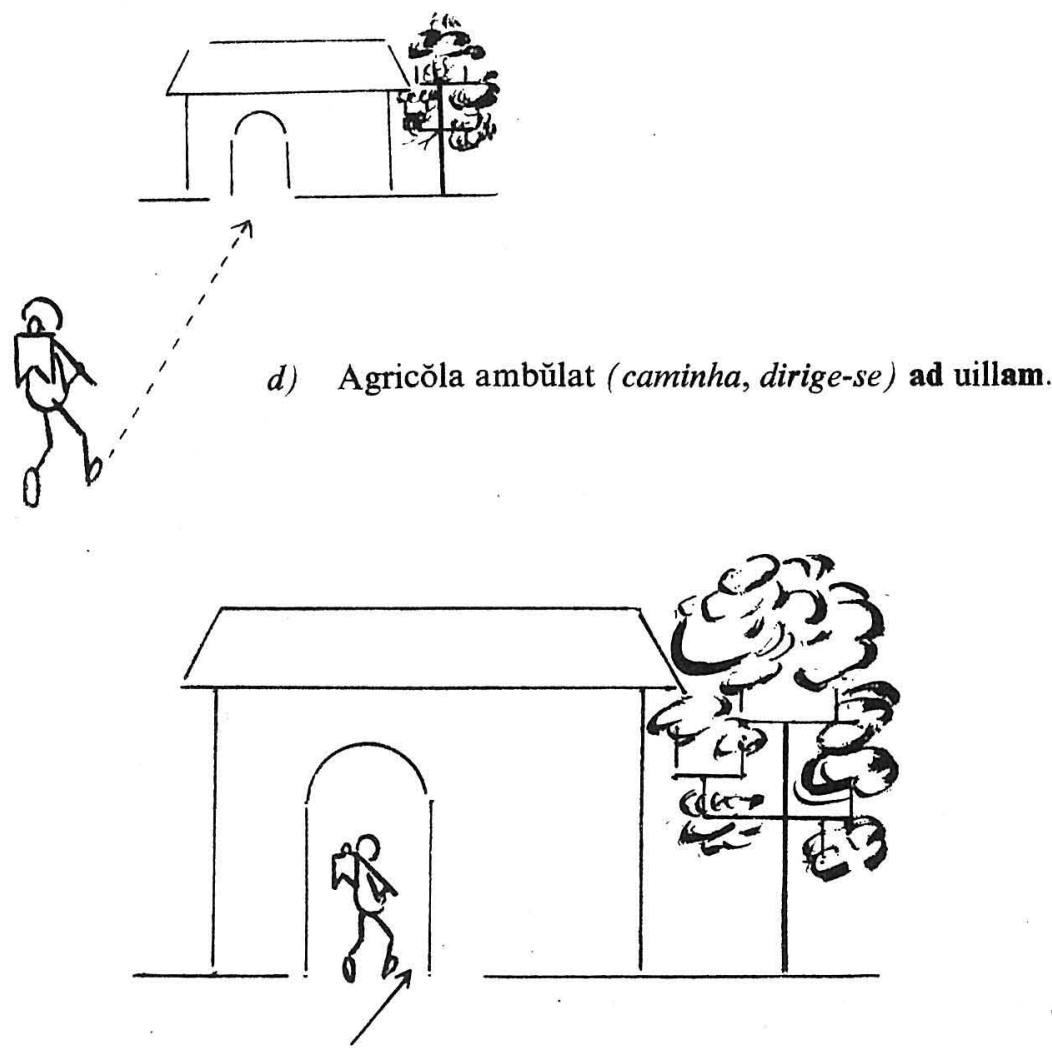

e) Agricŏla intrǒit (entra) in uillam. 


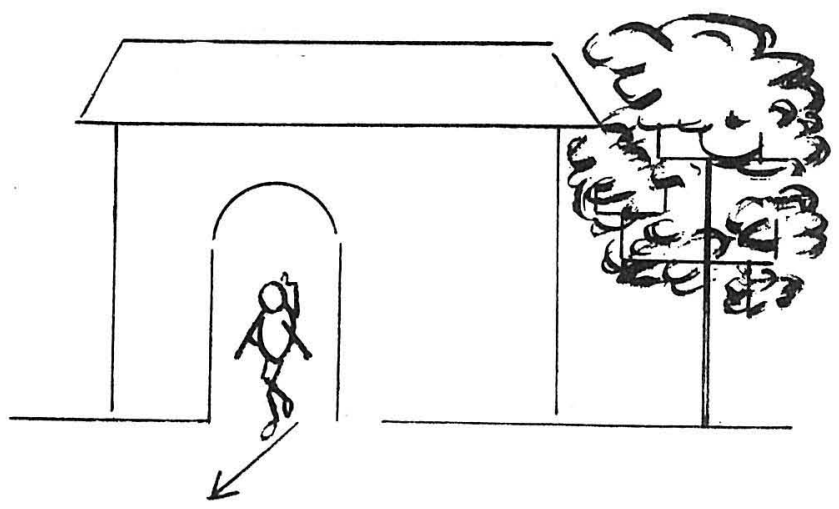

f) Agricǒla exit (sai) e(x) uillā

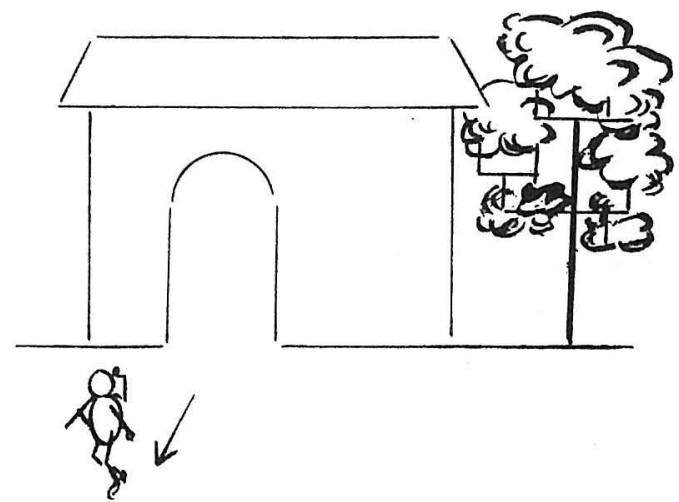

g) Agricŏla uěnit (vem) a(b) uillă.

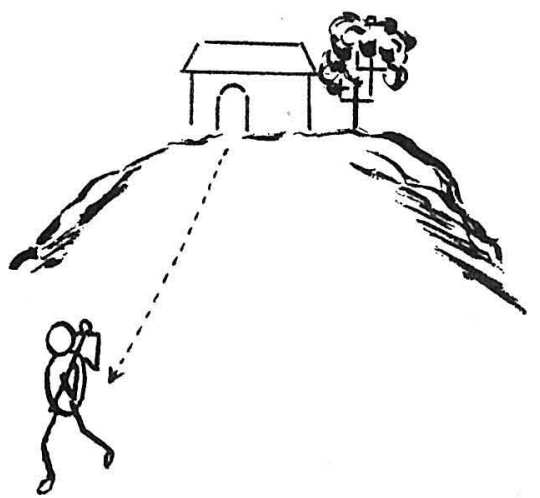

h) Agricŏla dēscendit (desce) dē uillā. 


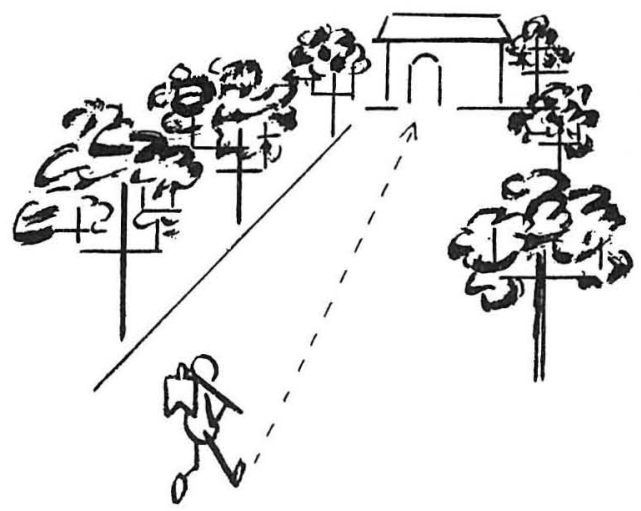

i) Agricŏla iter facit $(=f a z$ caminho $=$ caminha $)$ per siluam.

Lugar onde:

a) in + ablativo: em...

b) apud + acusativo: junto de...

c) circa + acusativo: à roda de; nas imediações de...

Lugar para onde:

d) ad + acusativo: para junto de...; em direcção a...

e) in + acusativo: para dentro de...

Lugar donde:

f) $e(x)+$ ablativo: de dentro de...

g) $a(b)+$ ablativo: de junto de...

h) $d \bar{e}+$ ablativo: de (cima para baixo)...

Lugar por onde:

i) per + acusativo: por...; através de... 


\section{QUESTIONÁRIO}

Vbi est agricǒla?

Vbi $?=$ Onde $?$

a)

Vbi est arbor?

b)

Vbi sunt gallus, gallina et pullus?

c)

Quō ambǔlat agricŏla?

Quō $?=$ Para onde?

d)

Vnde uenit agricŏla?

Vnde $?=$ De onde $?$

g)

Quã iter facit agricǒla?

Quā? = Por onde?

i) 


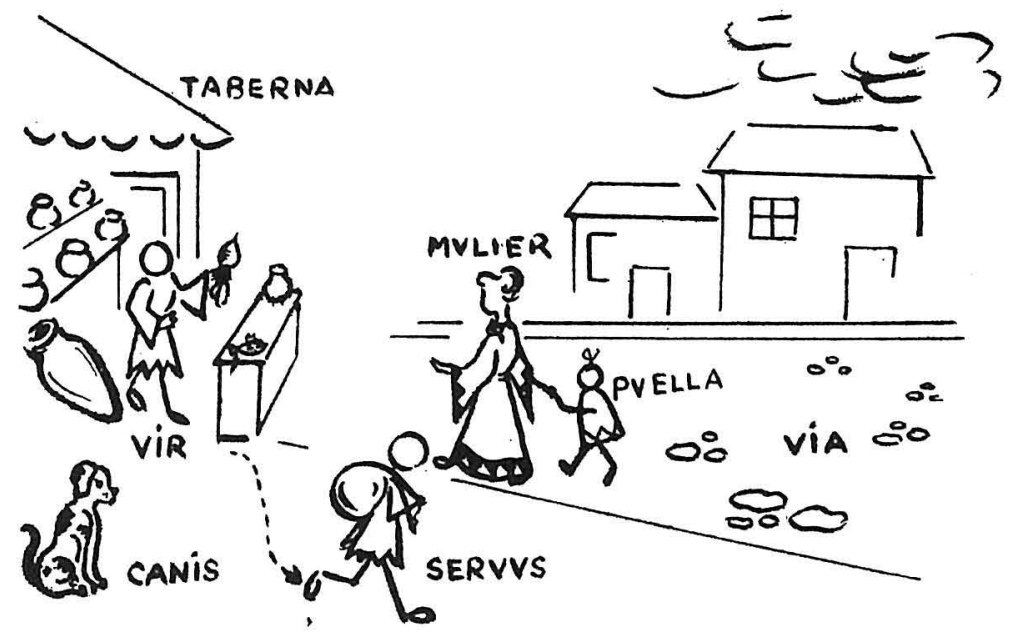

TABERNA RŌMĀNA EST IN PICTV̄RĀ.

Vir est in taberna: tabernarius est.

Mulier ambŭlat tabern

Puella quoque ambŭlat tabern.

Seruus uenit tabern......

Canis est tabern

Mulier et puella sunt ui.......

est mater; est filia.

Mater et filia iter faciunt urbem Rōmam. 


\section{QUESTIONÁRIO}

Quid est in pictūra?

In pictūra est

Quis est in taberna?

In taberna est

Quis est apud tabernam?

Apud tabernam est

Quis uěnit a taberna?

A taberna uĕnit

Vbi sunt mulier et puella?

Mulier et puella sunt

Quid est in amphŏra?

uinum.

Quid est in ampullis?

oleum.

Quid uir manu tenet?

napum.

Quid est super mēnsam?

et piscis.

Quid seruus uměrō portat?

saccum. 
Verta para latim (vd. p. 32):

A antiga cidade de Roma era grande e bela. Nas ruas de Roma havia muitas lojas. Os lojistas vendiam vinho, azeite e diversas mercadorias. O vinho estava nas ânforas; o azeite nos frascos (= nas ânforas pequenas) e nas garrafas. Nas garrafas também havia vinho.

$\mathrm{Na}$ gravura, o lojista está junto do balcão e segura um nabo. Sobre o balcão estão um peixe e uma garrafa. A senhora romana caminha, com a filha, para a loja. O escravo vem da loja e transporta um saco ao ombro. $\mathrm{O}$ cão guarda a loja.

\section{VOCABULÁRIO}

antiga: antiqua, ae bela: pulchra, ae diversa: diuersa, ae garrafa: lagoena, ae grande: magna, ae (ele) guarda: custōdit lojista: tabernarius; nom. pl. tabernarii mercadorias: ac. pl. mercēs muita: multa, ae senhora: matrōna, ae também: quoque vendiam: uendèbant 


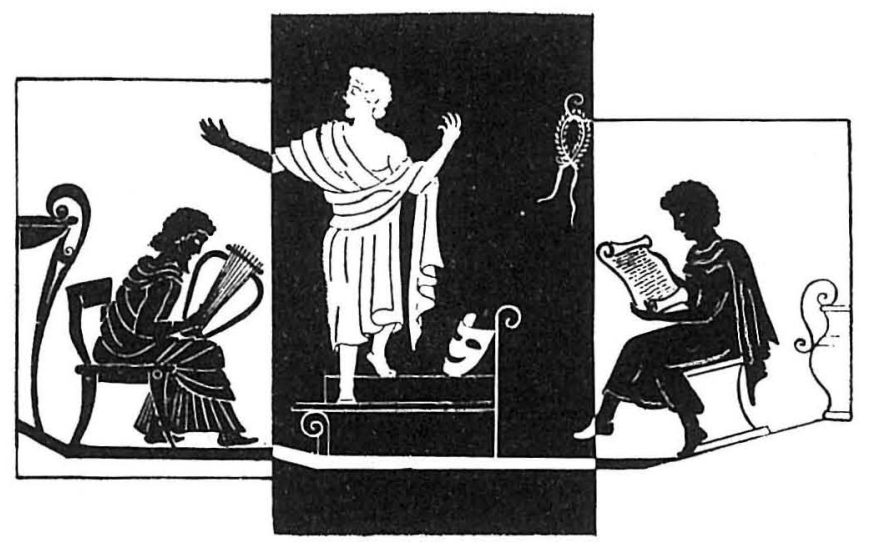

RECITAÇÃO

PASTORELA

Exit dilucǔlō

rustǐca puella

cum grege, cum bacǔlō,

cum lana nouella.

Sunt in grege paruǔlō

ouis et asella,

uitǔla cum uitǔlō,

caper et capella.

Conspexit in caespite scholārem sedēre:

- Quid tu facis, domine?

— Veni mēcum ludēre. *
Sai ao romper d'alva

a donzela aldeã

co cajado e o rebanho

de recente lã.

Há em seu rebanho

a ovelha e a burrinha,

a vitela e o vitelo,

$o$ bode e a cabrinha.

Viu em verde prado um estudante sentado:

- Que fazes, senhor?

- Vem brincar a meu lado.

\section{(dos Carminna Burāna)}

* Rigorosamente ludere; mas aqui ludëre por causa da rima. 


\section{CONJUGAÇÃO VERBAL}

Verbo ĚSSE 'ser; estar; existir; haver'

Presente do indicativo

sum

es

est

sumus

N.B.

estis

A 2. a pessoa do plural (cf. fr. êtes)

sunt foi substituída, no latim falado (latim vulgar) na Península Ibérica, por uma forma analógica de sumus/sunt que está na base do port. sois.

Assim:

*sŭtis $>$ sodes $>$ sois

Pretérito imperfeito do indicativo

eram
eras
erat
erāmus
erātis
erant
N.B.:

A acentuação das formas portuguesas éramos, éreis é analógica das restantes pessoas (todas elas acentuadas no radical).

OBSERVAÇÃO IMPORTANTE:

Como ESSE se conjugam os seguintes compostos:

$$
\begin{aligned}
& \text { abesse 'estar ausente'; } \\
& \text { adesse 'estar presente'; } \\
& \text { inesse 'estar em'; } \\
& \text { interesse 'estar entre'; } \\
& \text { obesse 'ser prejudicial'; } \\
& \text { praeesse 'estar à frente'; } \\
& \text { subesse 'estar debaixo'; } \\
& \text { superesse 'estar a mais'. }
\end{aligned}
$$




\section{EXERCÍCIOS DE APLICAÇÃO}

Estamos em Portugal, onde não só (nōn modo) há muitas

(multă, ae) tradições (memoriă, ae) e vestígios (reliquiae, ārum)

dos Romanos (Rōmanōrum), mas também (sed etiam) a língua

(lingua, ae) portuguesa é derivada da (dētortă $a+$ abl.) latina

(Latina, ae).

$\mathrm{Na}$ escola havia boas e más (mal̆a, ae) alunas.

Paula e Júlia, vocês são (= vós sois) amigas.

Eu estava na minha (mea, ae) casa de campo, nos arredores

de Condeixa, onde há muitos animais domésticos (pecūdēs:

feminino), como, por exemplo (uelut), galinhas, vacas, vitelas e cabras (capra, ae). 
1. ${ }^{a}$ conj.: infinitivo -āre: laudāre louvar

2. ${ }^{a}$ conj..: " -êre: monēre advertir

$3 .^{a}$ conj.: $\quad$-ĕre: rĕgěre governar ; capĕre capturar

$4 .^{a}$ conj.: " -ire: audire ouvir

\section{Presente do indicativo}

Voz activa

$\begin{array}{ll}\text { laudō } & (\text {-ō) } \\ \text { laudās } & \text { (-ās) } \\ \text { laudat } & \text { (-at) } \\ \text { laudāmus } & \text { (-āmus) } \\ \text { laudātis } & \text { (-ātis) } \\ \text { laudant } & \text { (-ant) }\end{array}$

moněō

monēs

monět

monēmus

monētis

monent

$\begin{array}{ll}\text { regō } & (-\bar{o}) \\ \text { regis } & (-i s) \\ \text { regit } & (-i t) \\ \text { regĭmus } & (-1 \text { mus) } \\ \text { regĭtis } & (- \text {-itis) } \\ \text { regunt } & (- \text { unt })\end{array}$

Voz passiva

(-or) laudor

(-āris) laudāris

(-ātur) laudātur

(-āmur) laudāmur

(-amǐni) laudamǐni

(-antur) laudantur

(-ěor) moněor

(-ëris) monēris

(-ētur) monētur

(-ēmur) monēmur

(-ēmǐni) monēmǐni

(-entur) monentur 
Voz activa

$\begin{array}{ll}\text { capiō } & \text { (-ī̄) } \\ \text { capis } & \text { (-is) } \\ \text { capit } & \text { (-it) } \\ \text { capĭmus } & \text { (-ĭmus) } \\ \text { cap̌rtis } & \text { (-ǐtis) } \\ \text { capiunt } & \text { (-iunt) }\end{array}$

audiō $\quad(-\mathrm{i} \bar{o})$

audis

audit

audimus

auditis

audiunt (-imus)

(-iunt)
Voz passiva

(-ior) capior

(-ěris) capěris

(-ĭtur) capitur

(-ĭmur) capĭmur

(-imĭni) capimĭni

(-iuntur) capiuntur

(-ior) audior

(-iris) audiris

(-itur) auditur

(-imur) audimur

(-imĭni) audiminni

(-iuntur) audiuntur

Outros verbos:

1. ${ }^{\mathrm{a}}$ conjugação

amāre

amar

cantāre

cantar

saltāre

dançar

$2 .^{a}$ conjugação

habēre ter; possuir (na pass.: ser considerado)

dēlēre destruir

tenēre ter; segurar

3. ${ }^{\mathrm{a}}$ conjugação

agĕre levar (à sua frente); acompanhar

dicěre dizer

legěre escolher; ler (como regěre)

facěre fazer (como capěre)

4. ${ }^{a}$ conjugação

reperīe descobrir

sentire sentir

sitire ter sede 


\section{Paulae in uillä}

Iulia Paulam uisistat. Iulia ad Paulae uillam uenit. Iulia ianuam pulsat. Ancilla ad ianuam uenit et apěrit. Iulia (in) uillam intrat. Iulia uillam circumspectat. Ancilla Iuliam ad exědram ducit. Paula ibi sedet. Paula Iuliam exspectat. Paula luliam uidet et surgit. Paula amicam salūtat:

- Saluē, Iulia!

- Saluē! - Iulia respondet. - Vbi sunt pater tuus et mater et frater?

- Pater meus - Paula inquit - in hortō labōrat; mater mea est in culina; frater pictūram pingit.

Paula ancillam uocat et dicit:

- Iulia, amica mea, èsŭrit.

Ancilla placentas appōnit. Iulia placentam gustat et exclānat:

- Haec placenta est optìma!

Puellae placentas consūmunt et rident.

Intěrim Paulae pater ad uillam reuĕnit et (in) exědram intrat. Marius puellas spectat et:

- Saluēte, puellae! - inquit - Cur laetae estis?

- Quia placentae sunt optǐmae! - puellae inquiunt.

Paulae mater è culīna exit et maritum ōsculātur, et Marius exclāmat:

- Ēsuriō! Iam est cēna parāta?

- Nōndum - inquit mulier.

Subĭtō clamōrem audiunt:

— Furcǐfer! Di tē perdant! — Paulae frater cum cane tumultuat. Nam canis apud picturam stat; picturam intentē spectat et ferōcǐter latrat.

Cur canis latrat?. Quia in pictura est... fëlēs! 


\section{VOCABULÁRIO}

ancilla, ae: criada, escrava

aperîre: abrir

appōnĕre: servir (à mesa)

audire: ouvir

canis, is: cão

cēna, ae: jantar

circumspectāre: observar em redor

clamor, oris: brado; barulho

consumerre: devorar; comer

cur?: por que motivo? porque

é que?

di tē perdant!: Que os deuses te

percam! Um rai's te parta!

Maldito sejas!

dicěre: dizer

ducěre: conduzir

essurire: estar com fome

exẽdra, ae: sala de visitas

exire: sair

exspectāre: estar à espera de

félēs, is: gato

ferōcüter: ferozmente

furcǐfer!: Patife!

gustāre: provar

hortus, $i$ : jardim; quintal

iam: já

ianua, ae: porta

ibi: aí; lá

inquit, inquiunt: diz, dizem intentē: atentamente

interrim: entretanto

intrāre $(+a c$. ou in $+a c$. $)$ : entrar

em

labōrāre: estar a trabalhar

latrāre: ladrar

maritus, $i$ : marido

nōndum: ainda não

ōsculāri (só forma pass.): beijar

parāta, ae: preparada; pronta

pictura, ae: quadro

pingerre: estar a pintar

placenta, ae: bolo

pulsāre $(+a c)$ : bater a

quia: porque; é que

reuĕnire: regressar

ridēe : rir

saluē, saluēte: bom dia!; olá!; viva $(\mathrm{m})$ !

salütāre: cumprimentar

sedēre: estar sentado

spectāre: observar

stāre: estar (de pé)

subǐtō: subitamente

surgĕre: levantar-se

tumultuāre: barafustar

uenire: vir; chegar a

uidēre: ver

uocāre: chamar 
AGENTE DA PASSIVA:

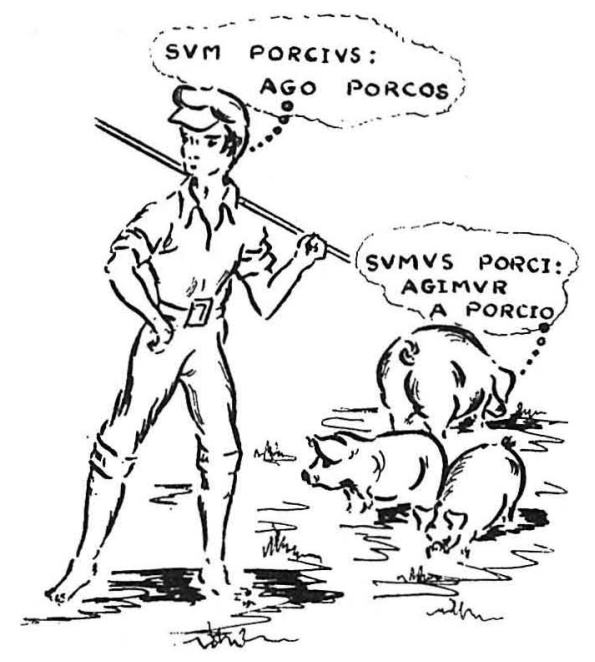

A professora louva as boas alunas.

Magistră bonas discipülas laudat.

As boas alunas são louvadas pela professora.

Bonae discipŭlae a magistrā laudantur.

O marinheiro adverte as filhas.

Nauta filias monet.

As filhas são advertidas pelo marinheiro.

Filiae a nautā monentur.

As tropas apoderam-se das riquezas.

Cōpiae diuitias capiunt.

As riquezas são tomadas pelas tropas.

Diuitiae a cōpiis capiuntur.

\section{MAS :}

Villa dēlētur flammis.

A casa de campo é destruida pelas chamas. 
I - PASSE PARA A VOZ PASSIVA:

Scriba littěras scribit.

Puellae linguam Latinam discunt.

Gallina ēscam quaerit.

Magistra discipŭlis fabŭlas narrat.

Discipŭlae fabŭlas dē deā Cypriā amant.

Iulia Paulam uisǐtat.

Paula et Iulia iucundam uitam agunt.

Iulia ianuam pulsat.

Ancilla ianuam apěrit.

Paula amicam exspectat.

Iulia Paulam salūtat.

Serua plạcentas appōnit.

Puellae placentas consūmunt.

Aduĕnae nostram patriam laudant.

Rustǐca puella asellam et capellas in agrum agit. 
II - PASSE PARA A VOZ ACTIVA:

N. B.:

O emprego do pronome pessoal sujeito não é muito usual em latim. É que em latim, ao contrário do que acontece em certas línguas modernas, como $o$ francês e $o$ inglês, as desinências pessoais, por serem suficientemente claras, bastavam para indicar a pessoa gramatical do sujeito.

Littěrae a mē scribuntur.

(Ego)

Epistŭla a nōbis leğtur.

(Nōs)

Vita rustǐca a tē amātur.

(Tu)

Placentae a uōbis consumuntur.

(Vōs)

A Paulā uillă apud Conimbrĭgam habitātur.

Pictură cane spectātur.

Nautae procellā terrentur.

Aquă $\mathrm{ab}$ ancillis in uillam portātur.

Discipŭlae a magistrā in scholam aguntur.

Maxĭmae gratiae Paulae ab Iuliā aguntur.

maximas gratias agěre $=$ dar os maiores agradecimentos = $=$ estar muito agradecido.

Multae diuitiae ab agricolā habentur. 


\section{EXERCÍCIOS SOBRE O ACUSATIVO}

a) Complemento directo:

Júlia visita (uisitāre) a [sua] amiga Paula.

As criadas trazem (portāre) ágıa.

b) Lugar para onde:

Júlia vem a (= para) Portugal.

Os marinheiros navegam (nauigāre) em direcção à ilha.

Os agricultores entram em casa (= para as casas: uilla, ae).

As criadas caminham em direcção à mata (silua, ae).

c) Lugar por onde:

Paula e Júlia caminham pelos bosques. 
1. APUD 'junto de; em casa de; na presença de; perante; na obra de': As meninas estão junto do bosque.

Júlia janta (cēnäre) em casa de Paula.

Os marinheiros estavam na presença da rainha.

No poeta Virgílio. (Vergilius: acusat. Vergilium) lê-se (= é lida) a história (historia, ae) de Eneias.

2. ANTE 'diante de; na presença de; antes de':

Paula e Júlia brincam em frente de casa.

Tu chegas (aduenire) antes da hora (höra, ae).

3. Cis e citra 'aquém de'.

Nós estávamos para cá (ou do lado de cá) da rua.

A casa de Paula está do lado de cá da mata. 
4. CONTRA 'em frente de':

A Grã-Bretanha (Britannia, ae) está situada (posita est) em frente da França (Gallia, ae).

5. INTER 'entre; no meio de; no número de':

Entre as alunas, Paula e Júlia são as mais aplicadas (studiōsissimma, ae).

6. INTRA 'no interior de; antes de (terminar)':

Nós chegamos antes do meio-dia (hōra sexta).

Eles estão escondidos (= escondem-se: se occultāre) nas matas.

7. IVXTA 'muito perto de; mesmo ao lado de':

Paula e Júlia estão a brincar (= brincam) pertinho de casa.

8. POST 'atrás de, depois de':

As casas estão atrás do bosque.

9. TRANS 'além de; do lado de lá':

Os agricultores estão do lado de lá dos bosques. 


\section{EXERCÍCIOS SOBRE O ABLATIVO}

a) Companhia:

Paulă est cum Iuliā.

b) Causa:

Puellă irā lacrĭmat.

c) Meio:

Agricŏlae filiă uillam ōrnat rosis.

d) Modo:

Seruă cum diligentiāa (= diligenter) labōrat.

Discipŭlae magnā cum curā student.

e) Agente da passiva:

Terră $a b$ agricolā arātur.

Siluă flammis dēlētur. 
1. CōRAM 'na presença de; perante':

Os marinheiros estavam na presença da rainha.

2. Svi 'debaixo de; no fundo de':

As formigas (formica, ae) habitam debaixo da terra (terra, ae).

3. PRAE 'à frente de':

As vacas caminham à frente do agricultor.

4. SVPER 'sobre; em cima de; por cima de':

As pombas (columba, ae) estavam (stäre) sobre as casas.

As águias (aquila, ae) voam (uolāre) sobre o bosque. 
1. ${ }^{0}$ tipo: nominativo -us: domĭnŭs o senhor.

2. ${ }^{\circ}$ tipo: $\quad$ (er e -ir: puĕr o rapaz; ager o campo; uĭr o homem.

3. ${ }^{\circ}$ tipo: $\quad$-um: templŭm o termplo.

Exemplos :

\begin{tabular}{|c|c|c|c|c|}
\hline $1 .{ }^{\circ}$ tipo & & $2 .^{\circ}$ tipo & & 3.0 tipo \\
\hline N. domǐnŭs & puěr & ager & uir & templŭm \\
\hline V. domĭně & puěr & ager & uir & templŭm \\
\hline Ac. domĭnŭm & puěrum & agrum & uirum & templŭm \\
\hline G. domĭni & puĕri & agri & uiri & templi \\
\hline D. dominnō & puěrō & agrō & uirō & templō \\
\hline Ab. domĭnō & puěrō & agrō & uirō & templō \\
\hline
\end{tabular}

Plural

$\begin{array}{lllll}\text { N. domĭni } & \text { puĕri } & \text { agri } & \text { uiri } & \text { templă } \\ \text { V. domĭni } & \text { puěri } & \text { agri } & \text { uiri } & \text { templă } \\ \text { Ac. domĭnōs } & \text { puěrōs } & \text { agrōs } & \text { uirōs } & \text { templă } \\ \text { G. dominōrum } & \text { puerōrum } & \text { agrōrum } & \text { uirōrum } & \text { templōrum } \\ \text { D. domĭnis } & \text { puĕris } & \text { agris } & \text { uiris } & \text { templis } \\ \text { Ab. dominis } & \text { puěris } & \text { agris } & \text { uiris } & \text { templis }\end{array}$

N.B. :

1. - São masculinos os substantivos terminados no nominativo do singular em -er e -ir, e a grande maioria dos terminados em -us.

2. - São femininos, entre outros, os nomes de árvores, como por exemplo:

pōpŭlus, i o choupo
pirus, i a pereira
mālus, i a macieira
persǐcus, i o pessegueiro 
3. - São neutros todos os substantivos terminados no nominativo do singular em -um, como por exemplo os nomes dos frutos:

pirum, i a pêra

mālum, i a maçã

perš̌cum, i o pêssego

\section{OBSERVAÇÃO}

Há palavras, nesta declinação, que só se usam no plural, como por exemplo:

arma, örum as armas

libĕri, ōrum os filhos (sem distinção de sexo)

Pompeii, örum Pompeios

Outras há que podem apresentar um significado diferente no plural. Assim:

auxilium, ii auxílio

castrum, i castelo

impedimentum, i obstáculo

ludus, i divertimento; escola auxilia, ōrum tropas auxiliares

castra, örum acampamento

impedimenta, ōrum bagagem do soldado

ludi, ōrum jogos (= espectáculos) públicos

\section{ADJECTIVOS DA PRIMEIRA CLASSE}

$1.0^{\circ}$ tipo:

Nominativo: -us, -a, -um: bonus, bona, bonum

2. ${ }^{\circ}$ tipo:

Nominativo: -er, -ĕra, -ěrum: liber, libĕra, liběrum

-er, -ra, -rum: pulcher, pulchra, pulchrum 


\section{DECLINAÇÃO}

\section{Singular}

N. bonus dominnus o bom senhor

$\mathrm{V}$. domine

Ac. dominum

G. domini

D. dominō

Ab. dominō

Plural

N domini

V. domini

Ac. dominōs

G. dominōrum

D. dominis

Ab. dominis

\section{Singular}

N. bonă seruă a boa escrava

V. serua

Ac. seruam

G. seruae

D. seruae

Ab. seruā

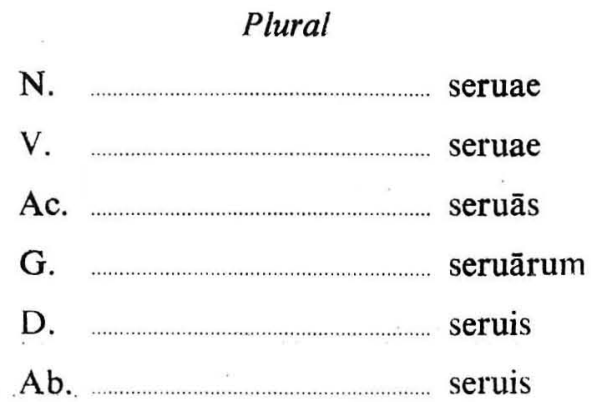




\section{Singular}

N. bonum mālum uma boa maçã

V. malum

Ac. malum

G. mali

D. malō

Ab. malō

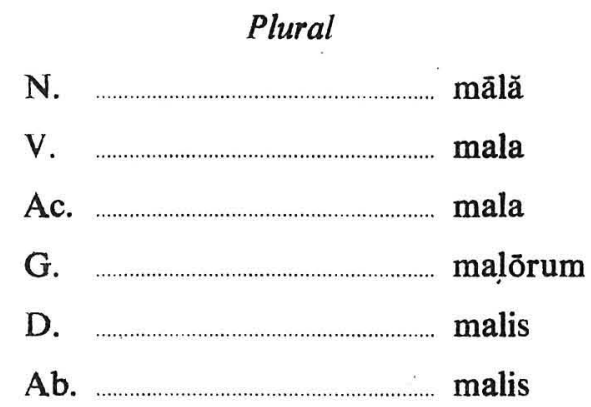

\section{Singular}

N. liber puer o rapaz (de condição) livre

V. puer

Ac. puĕrum

G. puĕri

D. puĕrō

Ab. puěrō

\section{Plural}

N.

puěri

V.

puěri

Ac.

puěrōs

G.

puerōrum

D. puěris

Ab. puěris 


\section{Singular}

N. liběră puellă a rapariga (de condição) livre.

V. puella

Ac. puellam

G. puellae

D. puellae

Ab. puellā

Plural

N.

puellae

V. puellae

Ac. puellās

G. puellārum

D. puellis

Ab. puellis

\section{Singular}

N. libĕrum uinum o vinho libertador (de cuidados)

V. uinum

Ac. uinum

G. uini

D. uinō

Ab. uinō

Plural

N uină

V. uina

Ac. uina

G. uinōrum

D. uinis

Ab. uinis 


\section{Singular}

N. pulcher ager um belo campo

V. ager

Ac.

agrum

G. agri

D. agrō

Ab. agrō

Plural

N. agri

V. agri

Ac. agrōs

G. agrōrum

D. agris

Ab. agris

\section{Singular}

N. pulchră uillă uma bela casa de campo

V. uilla

Ac. uillam

G. uillae

D. uillae

Ab. uillā

Plural

N.

uillae

V. uillae

Ac. uillās

G. uillārum

D. uillis

Ab. uillis 


\section{Singular}

N. pulchrum templum um belo templo

V. templum

Ac. templum

G. templi

D. templō

Ab. templō

\section{Plural}

N. templă

V. templa

Ac. templa

G. templōrum

D. templis

Ab. templis

\section{Singular}

N. mălus poēta o mau poeta

V.

Ac.

G.

D.

Ab.

\section{Plural}

N.

V.

Ac.

G.

D.

Ab. 


\section{Singular}

N. altă pōpŭlus um alto choupo.

V.

Ac.

G.

D.

Ab.

Plural

N.

V.

Ac.

G.

D.

Ab.

Outros exercicios:

1 - latus fluuius $o$ rio largo ignāuus nauta $o$ marinheiro cobarde impiger scriba $o$ escriba diligente declina-se como pulcher

2 - fēmInna barbăra uma mulher estrangeira sacra laurus o loureiro sagrado

3 - cruentum bellum uma guerra sangrenta atrum ōracŭlum $o$ oráculo sinistro 
I - POSSESSIvos:

Meus, mea, meum: meu, minha

Tuus, tua, tuum: teu, tua

Suus, sua, suum: seu, sua

Noster, nostra, nostrum: nosso, nossa

Vester, uestra, uestrum: vosso, vossa

\section{Claudius Rōmam ${ }^{1}$ aduěnit}

Claudius est Lusitānus et Lucius Rōmānus. Cum (quando) schola

nōn est, librōs legunt, per urbem ambǔlant aut in hortō ludunt.

Claudius et Lucius nōn sunt pigri. Nam diligenter studia colunt (estudam). Puěri autem amant

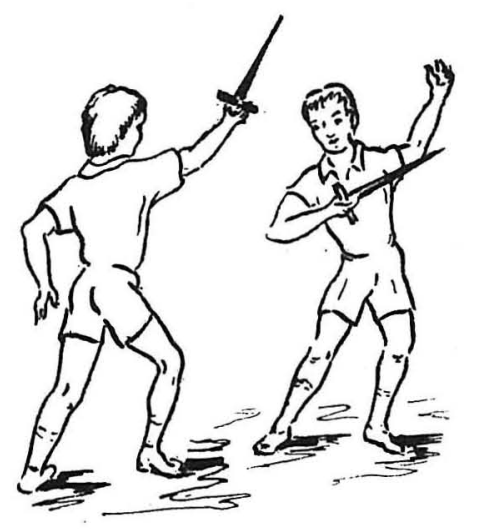

PVERI BELLA FINGVNT currẹ̆re et bella fingĕre (brincar às)

cum amicis. Studēre enim pul-

chrum est; sed ludĕre... magna

gaudia pueris dōnat (proporciona). 
Nunc fēriae sunt et ludi clausi sunt (estão encerradas). Quā dē causā (por essa razão) Claudius ab Aeminiō (Coimbra) Rōmam uēnit (veio) ad amicum suum Lucium, et apud eum (em casa dele) dēuertîtur (está hospedado). Claudiō et Luciō in sōle luděre ac per urbem ambulāre tōtō diē licet (é lícito; podem). Quarē (por esse motivo) Lucius amicum suum magnō cum gaudiō exč̣pit (recebe):

- Hauē, Claudi ${ }^{2}$, peropportunē (mesmo a propósito) aduĕnis: pater meus et mater mea tē exspectant (estão à tua espera). Iam cubiculum tibi paratum est: ueni et uidē!

Claudius autem - miser puer! - est dè uiā lassus (cansado).

Quam ob rem (por isso) Lucius amicum in atriō sedēre iubet (manda) et parumper (por uns instantes) quiēscĕre (descansar). Claudius:

- Luci 2, quam pulchra atque magna,» inquit ${ }^{3}$, «est domus tua! Tu magnificē habĭtas! 
Claudius et Lucius rident quod (porque) laeti sunt. Sed Lucius:

— Nunc (agora),» inquit ${ }^{3}$, «ad cubiculum tē ducam (vou levar-te).

1 Romam aduenit = chega a Roma.

Com nomes de cidades, o lugar para onde (ou aonde) exprime-se em acusativo sem preposição.

2 Claudi; Luci: vocativos.

Têm o vocativo do singular em -i (e não em -ie) os nomes próprios de origem latina em -Ius, e bem assim o substantivo comum filius.

Assim:

$$
\begin{aligned}
& \text { Antōnius } \longrightarrow \text { voc. Antōni } \\
& \text { Vergilius } \longrightarrow \text { voc. Vergili } \\
& \text { filius } \longrightarrow \text { voc. fili }
\end{aligned}
$$

Mas:

$$
\text { Darius } \longrightarrow \text { voc. Darie }
$$

3 inquit 'diz; disse' e inquiunt 'dizem; disseram' apenas são usados intercalados no discurso directo.

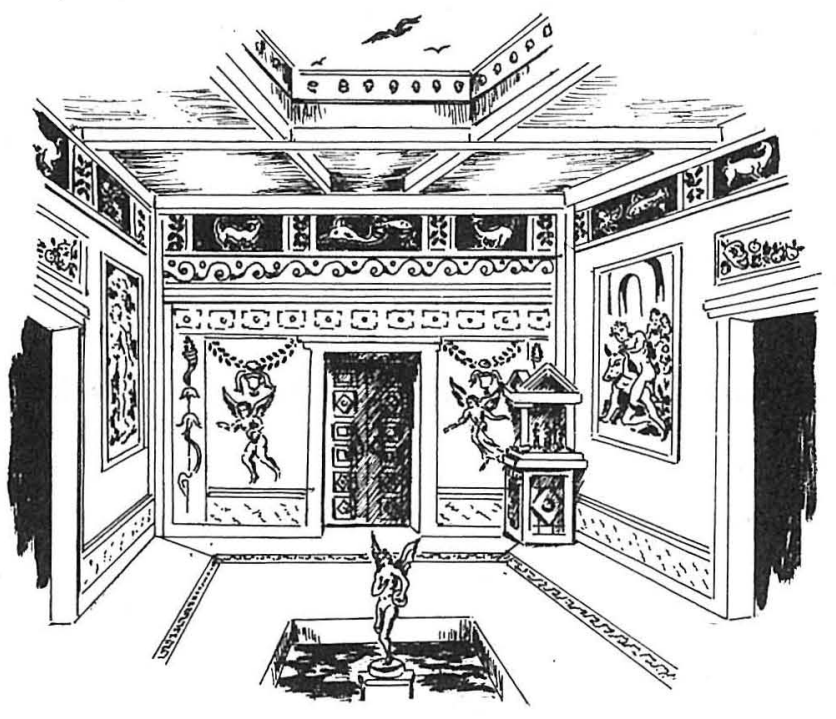




\section{QUESTIONÁRIO}

- Ex quã urbe Claudius uenit?

— Vbi est Aeminium? Et Rōma?

- Quis Claudium excĭpit?

— Quibus uerbis Lucius amicum salūtat?

- Vbi pueri sedent?

- Cur pueri sedent?

- Suntne pueri laeti? Cur?

\section{Verta para latim:}

O pai de Lúcio tem uma quinta (fundus, i) não longe de (nōn longē $a b+$ ablat.) Roma. Cláudio e Lúcio passeiam (ambulāre) pela quinta e observam (spectāre) os criados e as criadas a trabalhar (labōrantēs). $\mathrm{O}$ velho (uetus) criado Pedro (Petrus, $i)$ leva (agère) os touros (taurus, $i$ ) e as vacas para o prado (pratum, $i$ ).

Uma vez os animais (bestia, ae) espantam-se (trepidäre) e fogem (fugère: ind. do pres. fugio, como capio, p. 35) do prado para a mata. Pedro, com Lúcio e Cláudio, dirige-se apressadamente (properāre) para a mata. É que na mata havia lobos (lupus, $i$ ). Pedro e os rapazes encontram (inuenire) as vacas e os touros fugitivos (fugitiuus, $a, u m$ ) e reconduzem[-nos] (reducère) não sem custo (haud facile) para a quinta. 

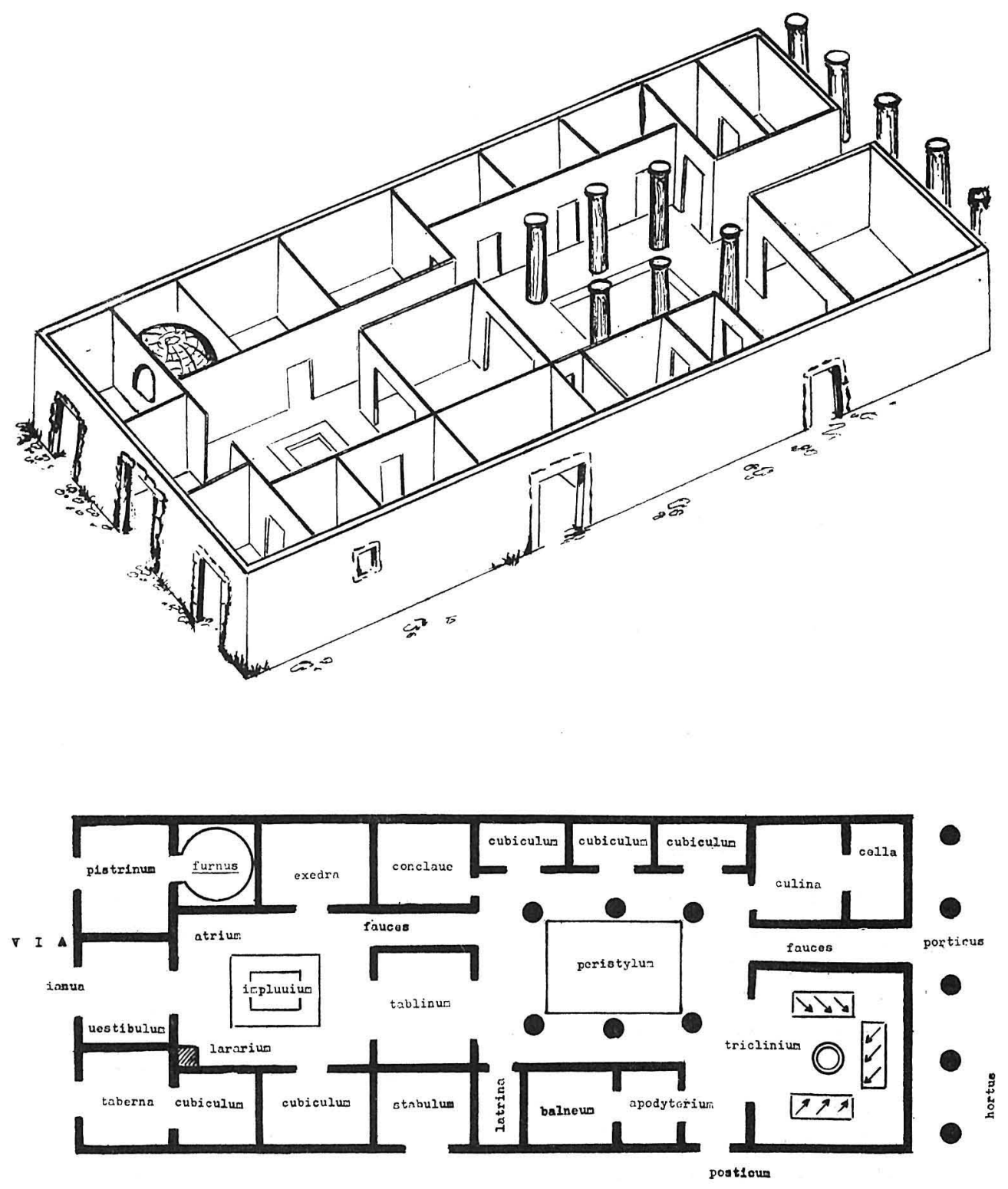


\section{VOCABULÁRIO}

$D O M V S, V S$ : casa; vivenda.

insŭla, ae: grande edifício com andares, habitado por famílias pobres.

ianua, ae: porta de casa.

fenestra, ae: janela.

uestibülum, $i$ : vestíbulo.

atrium, ii: átrio.

lararium, ii: altar consagrado aos

Lares.

impluuium, ii: implúvio.

compluuium, ii: complúvio.

exèdra, ae: sala de reunião ou recepção.

cubicŭlum, $i$ : quarto de dormir. conclāue, is: compartimento fechado à chave.

faucēs, ium (pl.): corredor.

tablinum, $i$ : escritório e biblioteca. stabũlum, $i$ : estábulo. peristȳlum, $i$ : peristilo. latrina, ae: latrina.

balneum, $i$ : quarto de banho. apodytērium, ii: vestiário.

frigidarium, ii: banhos frios. tepidarium, ii: banhos tépidos. caldarium, $i i$ : banhos quentes. culina, ae: cozinha.

cella (ae) uinaria (ae): adega. oecus, $i$ : salão.

triclinium, ii: triclínio; sala de jantar.

posticum, $i$ : porta traseira.

porticus, us: pórtico.

hortus, $i$ : quintal; jardim.

taberna, ae: loja.

pistrinum, $i$ : padaria (pastelaria). furnus, $i$ : forno.

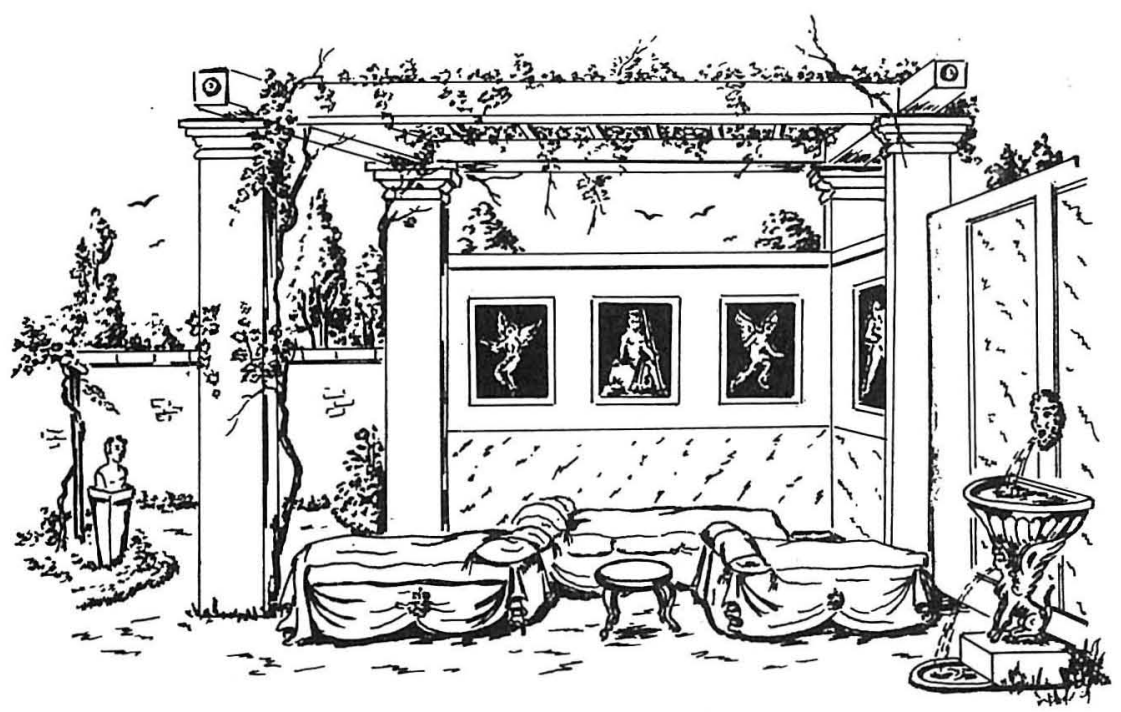

TRICLINIVM AESTIVVM 


\section{A FAMÍl IA ROMANA}

$\left.\begin{array}{l}\text { Canis } \\ \text { Pater } \\ \text { Ianĭtor } \\ \text { Mater } \\ \text { Filia } \\ \text { Filius }\end{array}\right\}$ uocātur $\left\{\begin{array}{ll}\text { Cerběrus } & \text { Seruua } \\ \text { Marcus Antōnius Fēlix } & \text { Coquus } \\ \text { Ianus } & \text { Seruus } \\ \text { Claudia } & \text { Auus } \\ \text { Antōnia } & \text { Auia } \\ \text { Gaius Antōnius Pulcher } & \text { Hortulānus }\end{array}\right\}$ uocātur $\begin{aligned} & \text { Seruilia } \\ & \text { Congriō } \\ & \text { Vinius } \\ & \text { Lucius A. Fēlix } \\ & \text { Cornēlia } \\ & \text { Hortēnsius }\end{aligned}$

Cerběrus est in uiā ante ianuam.

Marcus Antōnius Fēlix ē forō uěnit.

Canis dominnum uidet et alacríter latrat.

Antōnius ianuam pulsat.

Ianus est in uestibǔlō.

Ianı̌tor audit et ianuam apěrit.

Pater domum intrat et uxōrem uidet.

Mater in atriō apud lararium sedet. 
Antōnius Claudiam salūtat.

Filia in cubicưlō dormit.

Antōnia est pigra puella.

Filius in tablīnō legit et scribit.

Gaius Antōnius Pulcher est impigger puer.

Serua in tricliniō labōrat.

Seruilia triclinium lauat.

Coquus in culinā coquit.

Congriō congrum ad prandium parat.

Seruus in cellă uinariā est.

Vinius uinum merum clancŭlum bibit: ēbriősus est.

Auus et auia sunt senēs. 
Lucius auus et Cornēlia auia circa peristȳlum ambülant.

Hortulānus est in hortō.

Hortēnsius flōrēs in hortō colit.

Tabernarius est in taberna.

Tabernarius uinum et alias mercēs uendit.

Pistor in pistrinō labōrat.

Pistor panem et placentas uendit.

Marcus Antōnius Fēlix multōs equōs habet: nam est diues.

Equi sunt in stabǔlō.

In urbe Rōmā erant magna et alta aedificia, insũlae uocāta.

In insulis multae familiae erant.

Familiae paupĕrēs insŭlas habitābant. 


\section{QUESTIONÁRIO}

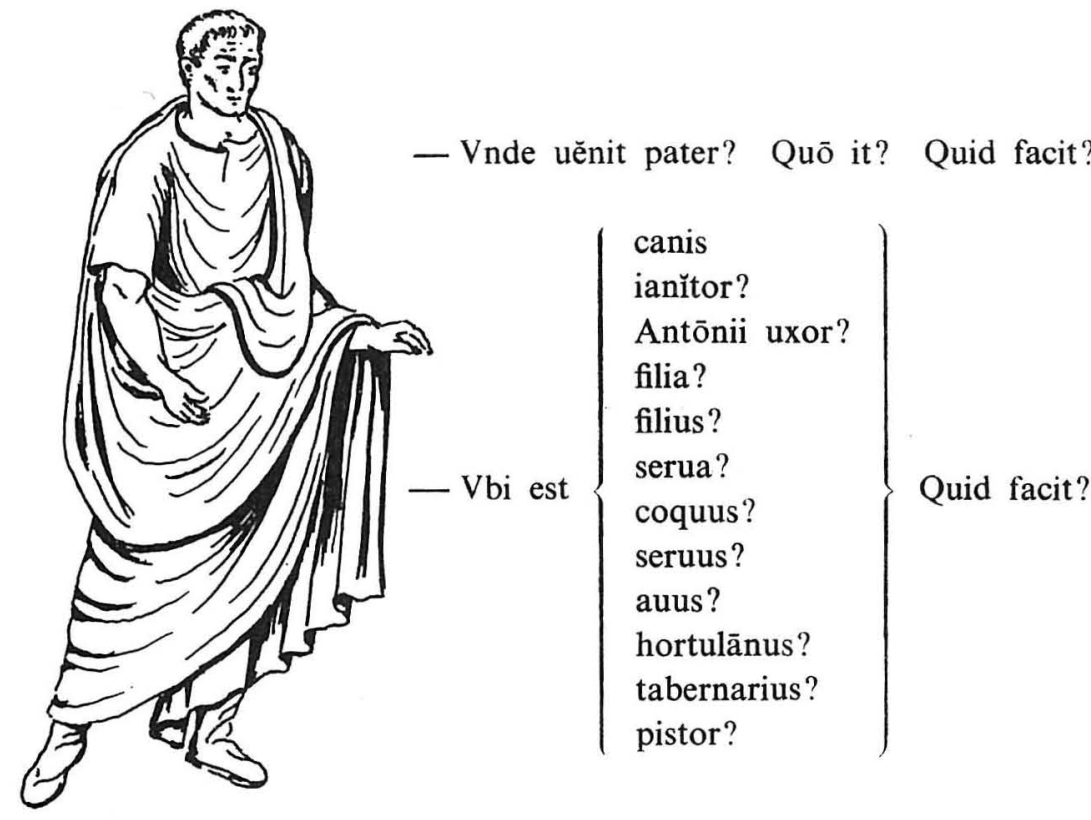

— Quid est in mediō atriō?

—Quis est $\left\{\begin{array}{l}\text { in uestibŭlō? } \\ \text { in tablinōo } \\ \text { in culīna? } \\ \text { in cella uinaria? } \\ \text { in hortō? }\end{array}\right.$

—Quod nōmen est $\left\{\begin{array}{l}\text { ianitōri? } \\ \text { seruae? } \\ \text { seruō? } \\ \text { coquō? } \\ \text { hortulānō? }\end{array}\right.$

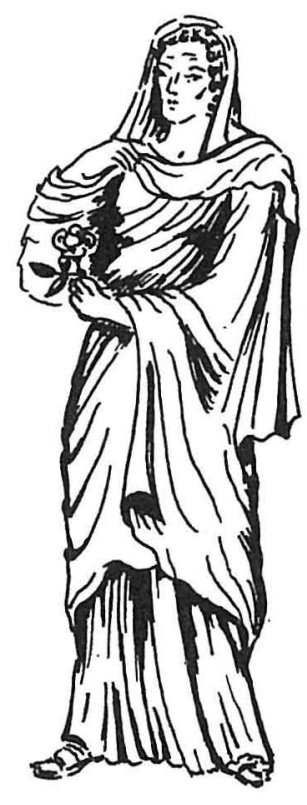




\section{DECLINAÇ ÃO PRONOMINAL \\ (continuação)}

II - DEMONSTRATIVOS :

Hic, haec, hŏc: este, esta, isto

Iste, ista, istud: esse, essa, isso

Ille, illa, illud: aquele, aquela, aquilo

Is, ea, id: aquele, ...; o, a; ele, ela

Idem, eădem, idem: o mesmo, a mesma, a mesma coisa

Ipse, ipsa, ipsum: o próprio, a própria, a própria coisa

DECLINAÇÃO

Singular

$\begin{array}{lll}\text { N. hic } & \text { haec } & \text { hŏc } \\ \text { Ac. hunc } & \text { hanc } & \text { hoc } \\ \text { G. } & \text { huius } & \\ \text { D. } & \text { huic } & \end{array}$

Ab. hōc hāc hōc

Singular

$\mathrm{N}$. iste ista istud

Ac. istum istam istud

G. istius

D. isti

Ab. istō istā istō

\section{Plural}

$\begin{array}{lll}\text { hì } & \text { hae } & \text { haec } \\ \text { hơs } & \text { hās } & \text { haec } \\ \text { hōrum } & \text { hārum } & \text { hōrum } \\ & \text { hīs } & \end{array}$

his 


\section{Singular}

N. ille illă illud

Ac.

G.

D.

Ab.

\section{Plural}

N. illī
Ac......$\cdots \ldots \ldots \ldots \ldots \ldots \ldots$
G. $\quad \ldots \ldots \ldots \ldots \ldots \ldots \ldots \ldots \ldots \ldots \ldots \ldots$
D.

Ab.

Singular

N. is eă. id

Ac. eum eam id

G. eius

D. ei

Ab. eō eā eō illae

illă

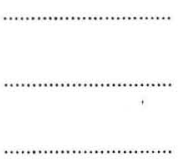

Plural

ii $(o u$ i $o u$ ei) eae eă

eōs eās ea

eōrum eārum eōrum

iis (ou is $o u$ eis)

iis (ou is $o u$ eis) 


\section{Singular}

N. idem eădem idem

Ac. eundem eandem idem

G.

D.

Ab.

Plural

N. idem eaedem eădem

Ac.

G.

D.

Ab.

Singular

$\begin{array}{lll}\text { N. ipse } & \text { ipsa } & \text { ipsum } \\ \text { Ac. ipsum } & \text { ipsam } & \text { ipsum } \\ \text { G. } & \text { ipsīus } & \\ \text { D. } & \text { ipsī } & \\ \text { Ab. ipsō } & \text { ipsā } & \text { ipsō }\end{array}$

\section{Plural}

N. ipsi ipsae ipsă

Ac.

G.

D.

Ab.

i 
III - ADJECTIVOS PRONOMINAIS:

Alius, alia, aliud: outro, outra (de vários)

Alter, altěra, altĕrum: outro, outra (de dois) (Vide NUMERAIS)

Vter, utra, utrum: qual (dos dois, das duas)

Neuter, neutra, neutrum : nem um nem outro; nem uma nem outra

Vterque, utrăque, utrumque: um e outro; uma e outra; ambos, -as

Vnus, a, um: um, um só; uma, uma só (Vide Numerais)

Vllus, a, um: algum, alguma

Nullus, nulla, nullum: nenhum, nenhuma

Nōnnullus, a, um: algum; alguma

Sơlus, a, um: só; sozinho

Tờtus, tōta, tōtum: todo inteiro (indivisível)

N.B.: Alius, alia, aliud declina-se como iste, ista, istud; os restantes (excepto no GENIT. e DAT. do singular, respectivamente em -ius e $-i$ ) declinam-se como os adjectivos da primeira classe dos tipos -us, -a, -um; -er, -ěra, -ĕrum; -er, -ra, -rum.

\section{Lucii nutrix fabŭlam mirabłlem narrat}

Apud Lucium erat anus nutrix quae fabŭlas multas dē strigis sciēbat. Post cēnam Lucius:

- Nutrix,» inquit, «sis nōbis fabŭlam narra.

- Date opěram: fabǔlam mirabĭlem narrābō: «Ōlim agricőla quidam per siluam ambulābat. Nox erat, sed luna lucēbat tanquam meridiē. Tertiā ferē uigiliā aduěnit ad sepulcrētum et, quia dē uiā erat fessus, cantabundus in monumentō sidit. Ecce repentē pedum crepitum silenti nocte audit, resp̌cit et umbram stantem inter stēlas uidet. Impaǔdus ad umbram appropinquat. Erat autem miles, fortis tanquam taurus.

- Quis tu es?» inquit agricŏla. Miles silentium tenet. Tum agricǒla irātus:

- Quid mē adspectas, stolĩde? Quid uis aut quis homō tu es? Miles uerbum nullum facit.

- Quid negōtii apud has stēlas tibi est, sceleste?» agricőla etiam atque etiam rogat; sed miles nihil dicēns inč̌pit sē exuěre et omnia ues- 
timenta super stēlam pönit. Nunc agricŏla stabat tanquam mortuus. At miles sub̌̌tō lupus factus est, ululāre incǐpit et in siluas fugit. Deinde agricǒla àd uestimenta accēdit: illa autem lapiděa facta sunt. Agricŏla rem intelligit: ille miles erat uersipellis.»

\section{VOCABULÁRIO}

accēdère: aproximar-se

adspectāre: observar

anus, us: velha

appropinquäre: aproximar-se

at: mas, porém

cantabundus, a, um: que canta;

a cantarolar

cēna, ae: jantar

däre: dar

date opěram: prestem atenção

deinde: em seguida

dicěre: dizer

nihil dicēns: sem nada dizer ecce!: eis!

etiam: também

etiam atque etiam rogāre: insis-

tir (perguntando)

exuëre: despir

facère: fazer

factus est: transformou-se

ferē: quase; cerca de

fessus, a um: cansado

fugẽre: fugir

homō, hominis: homem

Quis homō tu es?: Que espécie

de homem és tu?

impauıdus, a um: sem medo

inciperre: começar

intelligère: compreender

rem intelligère: compreender

um facto, o que se passa.

lapidèus, $a$, um: de pedra lucēere: brilhar

luna, ae: lua

lupus, $i$ : lobo

meridiēs, èi: meio-dia

meridiē: ao meio-dia

miles, miluttis: soldado

mirabülis, $e$ : admirável; singular

monumentum, $i$ : túmulo

mortuus, a, um: morto

narrāre: contar

narrabō: eu contarei; eu vou contar

negōtium, ii: negócio

Quid negōtii tibi est?: Que tens tu que fazer?

nox, noctis: noite

silenti nocte: no silêncio da noite

nutrix, icis: aquela que amamenta: ama

ōlim: era uma vez... que...

omnis, e: todo

pēs, pédis: pé

pedum crepitus: ruído de passos

pōnère: pôr

quidam: um certo

repentē: de repente

respicẽre: olhar para trás

scelestus, a, um: maldito

scire: saber

sepulcretum, $i$ : cemitério 
silentium, $i i$ : silêncio

silentium tenēre: guardar silêncio

silua, ae: mata; bosque

sis: vd. uelle

stāre: estar de pé

stans, stantis: que está imóvel stēla, ae: coluna tumular

stolidus, a, um: palerma

striga, ae: bruxa

subĭtō: subitamente

tanquam: como

uelle: querer

uis: tu queres

sis $=$ si uis: se te apraz; por

favor uerbum, $i$ : palavra

uerbum nullum facēre: não dizer palavra; não abrir bico

uersipellis, is: aquele que muda de pele; lobisomem

uestimentum, $i$ : vestuário; no pl. roupa

uigilia, ae: vigília (uma das quatro divisões da noite)

tertiā ferē uigiliāa: cerca da meia-noite

ululāre: uivar

umbra, ae: sombra; fantasma

ORAÇÕES INTERROGATIVAS DIRECTAS

I - Advérbios interrogativos (vide p. 27).

II - Partículas interrogativas:

1. Interrogativas simples:
a) -ne...?
b) Nōnne...?
c) Num...?
d) An...? 
EXEMPLOS:

a) Vidistine amicum tuum? $-\left\{\begin{array}{l}\text { Vidi. } \\ \text { Nōn uidi. }\end{array}\right.$

b) Nōnne amicum tuum uidisti? - Vidi.

c) Num amicum tuum uidisti? - Nōn uidi.

d) An amicum tuum uidisti? $-\left\{\begin{array}{l}\text { Vidi. } \\ \text { Nōn uidi. }\end{array}\right.$

Outros exemplos:

a) $-\mathrm{Tu}$ receias isso? $-\left\{\begin{array}{l}\text { Receio, pois. } \\ \text { Qual quê! }\end{array}\right.$

- Tune id uerēris? $-\left\{\begin{array}{l}\text { Vereor. } \\ \text { Nön uereor. }\end{array}\right.$

- Já estás a vê-lo $?-\left\{\begin{array}{l}\text { Estou, sim. } \\ \text { Ainda não. }\end{array}\right.$

- Eumne iam uidēs? $-\left\{\begin{array}{l}\text { Videō. } \\ \text { Nōn uideō. }\end{array}\right.$

- Mas eu cá sou um patife? $-\left\{\begin{array}{l}\text { És, és. } \\ \text { Não és nada. }\end{array}\right.$

- Egŏne uẹbĕrō sum? - $\left\{\begin{array}{l}\text { Es. } \\ \text { Nōn es. }\end{array}\right.$

b) - Então não receias isso? - Se receio!

- Nōnne id uerēris? - Vereor.

- Mas então não estás já a vê-lo? — Lá isso estou.

- Nōnne eum iam uidēs? - Videō.

- Mas então sou eu um patife? - Tu o dizes.

- Nōnne ego uerbĕrō sum? - Es. 
c) - Queres mais alguma coisa de mim? - Que te sumas!

- Num quid [=alǐquid $]$ mē uis? - Abi!

— Não receias isso, pois não? - É o receias!

- Num id uerēris? - Nōn uereor.

- Ainda não estás a vê-lo, pois não? - Não.

— Num eum iam uidēs? - Nōn uideō.

- Então eu sou um patife? - Claro que não.

- Num ego uerběrō sum? - Nōn es.

\section{EXERCícIOS :}

Lês o livro (liber, ri $) ?-\left\{\begin{array}{l}\text { Leio, sim. } \\ \text { Não, não leio. }\end{array}\right.$

a)

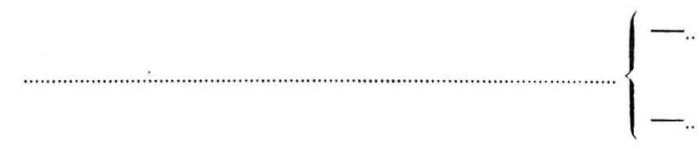

É verdade que lês o livro? - Leio, pois.

b)

Não lês o livro, pois não? - Não, não leio.

c)

Lês $\left\{\begin{array}{l}\text { por acaso } \\ \text { porventura }\end{array}\right\}$ o livro? $-\left\{\begin{array}{l}\text { Leio, sim. } \\ \text { Não, não leio. }\end{array}\right.$

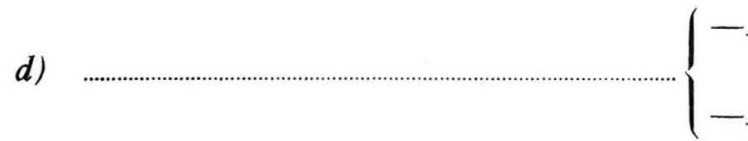


2. Interrogativas duplas:

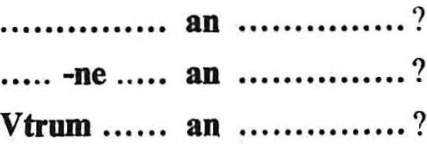

N. B.:

an nōn?

EXEMPLOS:

Venis an manēs?

Venisne an manēs?

Vtrum uenis an manēs? \{ Nōn eō.

$\left.\begin{array}{l}\text { Venis } \\ \text { Venisne } \\ \text { Vtrum uenis }\end{array}\right\}$ an nōn?

Outros exemplos:

— Mas então ele é um patife ou um homem de bem?

(-Verbèrō est an homō probus?

- Verbërōne est an homō probus?

- Vtrum uerberrō est an homo probus?

- Mas tu ai és homem ou mulher?

- Mas tu és homem ou não?

- Vir es an mulier?

- Vir es an nōn?

- Virne es an mulier?

- Virne es an nōn?

- Vtrum uir es an mulier?

- Vtrum uir es an nōn?

\section{EXERCÍCIOS :}

Lês o livro ou escreves a carta?

Lês o livro ou não?

N.B.: A resposta afirmativa pode também ser dada com os advérbios ITA, SANE ou SANE QVIDEM.

Exemplo:

$$
\text { Vidistine amicum tuum? }-\left\{\begin{array}{l}
\text { Ita. } \\
\text { Sane. } \\
\text { Sane quidem. }
\end{array}\right.
$$


Emprego dos advérbios nempe $e$ immō.

1. NEMPE:

- Nempe hic tuus seruus est? - Meus est.

Este aqui é teu escravo, não $\dot{e} ?-\mathrm{E}$, pois!

- Nempe pater tuus rēctē ualet? - Rēctē ualet.

- O teu pai está bom de saúde, não está? - Está, sim.

- Nempe librum lēgisti? - Lègi.

- Leste o livro, não é verdade? - $\mathrm{Li}$, sim.

2. IMMŌ:

- Hicne amicus tuus est? - Immō eius frater.

— Este aqui é o teu amigo? - Não, é o irmão.

— Quid apud has aedēs negōtii est tibi? — Immō quid tibi est?

- Que tens tu a cheirar nesta casa? - Homessa!

E tu?

- Silēbisne? - Immō uērō uerba faciam!

— Vais ficar calado? - Qual quê?! Hei-de falar!

- Nihilne pecuniae habēs? - Immō etiam!

- Não tens mesmo dinheiro? - Lá isso é que tenho!

Catilina tamen uiuit. Viuit? Immō uêrō etiam in senatum uenit!

$\mathrm{E}$, no entanto, Catilina está vivo. Vivo?! Ele aṭé vem ao Senado!

- Manēbisne domi? - Immō contra exibō!

- Vais ficar em casa? - Nem pensar nisso! Vou mas é sair! 


\section{CONJUGAÇÃO VERBAL}

Pretérito imperfeito do indicativo

Voz activa
laudā-ba-m
laudā-bā-s
laudā-ba-t
lauda-bā-mus
lauda-bā-tis
laudā-ba-nt

lauđā-ba-nt
Voz passiva

laudā-ba-r

lauda-bā-ris

lauda-bā-tur

lauda-bā-mur

lauda-bā-mĭni

lauda-ba-ntur monēbam

regēbam monēbar

regēbar 


\section{RECITAÇÃo}

\section{Carpe diem}

Omittāmus studia;

dulce est dēsipěre,

et carpāmus dulcia

iuuentutis tenĕrae;

rēs est apta senectūti

sēriis intenděre.

Vēlōx aetas praetěrit

studiō dētenta,

lasciuire suggěrit

tenĕra iuuenta.
Deixem-se de estudos;

doce é descansar;

colham-se as delícias

dos anos em flor;

da velhice é próprio

do sério cuidar.

Veloz passa a vida

levada a estudar;

nossos verdes anos

são só pra folgar.

(dos Carmina Burāna) 


\section{Lauatiō inuita.}

Olim sudum erat: nam summa erat aestas. Lucius et Claudius prandēre iuxta fluuium constituunt. Qua dē causa Lucii mater seruam ad ripam fluuii cibum et pōma portāre iubet. Pueri laeti ad fluuium cum serua properant. Dum serua prandium parat, Lucius et Claudius per ripam ambulābant. Subitō taurus ex agrō uicinō ad fluuium currit. Serua paữda exclāmat et pueri in aquam uestiti cadunt. Petrus seruus ad fluuium currit - nam taurum nōn timēbat - et cum nōnnullis aliis seruis taurum in agrum fugat. Tum pueri commadentēs in ripam ascendunt et, dum serua lacrimmas multas fundit, rident et libenter edunt: fluuii enim aqua famem irritat!

\section{VOCABULÁRIO}

aestas, ātis: verão

summa aestas: o pino do verão

ascenděre: subir; trepar

caděre: cair

cibus, i: comida; refeição

commadēre: estar todo molhado

commadentēs: (que estão) encharcados ou numa sopa

constituěre: decidir; resolver

currĕre: correr

dum: enquanto

edĕre: comer

exclamāre: gritar

famēs, is: fome

fugāre: afugentar; afastar

fundĕre: derramar

lacrĭmas multas funděre: debu-

lhar-se em lágrimas

inuitus, a, um: forçado irritāre: estimular

famem irritāre: abrir o apetite

iubēre: mandar; ordenar

lauatiō, ōnis: banho

libenter: com apetite

ōlim: certa vez

parāre: preparar

pauĭdus, a, um: assustado

pōmum, i: fruto; pl. fruta

portāre: levar

prandēre: almoçar

prandium, ii: almoço

ripa, ae: margem

subĭtō: de repente

sudus, a, um: seco; sem chuva

sudum, i: o tempo seco

sudum esse: estar bom. tempo

timēre: recear; ter medo

uestitus, a, um: vestido

uicinus, a, um: vizinho 
COMO EXPRIMIR A POSSE

1- Habēre + acusativo (= complemento directo) :

Agricŏla magnam uillam habet.

2-Esse + dativo (= dativo de possuidor):

Est agricolae magna uilla.

Tradução literal:

Tradução preferivel:

3-Esse + genitivo (= genitivo de possuidor):

Liber est magistri.

4 - Esse + in + ablativo :

Ingenium in Antōniō est.

Tradução literal:

Tradução preferível:

5 - Inesse + dativo (ou in + ablativo)

Ingenium Antōniō (ou in Antōniō) inest.

Tradução literal:

Tradução preferível: 
EXERCÍCIOS:

Paulo tem muitos amigos.

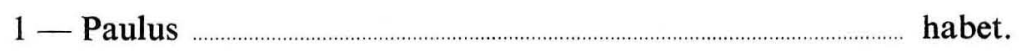

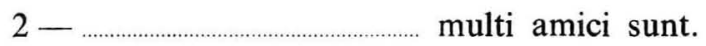

Estes livros são dos alunos.

3- Hi libri ......................................................................................... sunt.

Homens (uir, ri) e mulheres (fēminna, ae) são dotados de razão.
4 atque ratiō est.
$5-$ atque ratio inest.

N.B.:

As expressões chamar-se e chamado podem ser vertidas dos seguintes modos:

1. pelo dativo (de um pronome pessoal, demonstrativo ou relativo: dativo de possuidor $)+$ esse + nōmen $+\mathbf{o}$ nome próprio (a concordar em caso com nōmen, ou em dativo, a concordar, por atracção, com o pronome).

Exemplos:

Mihi est nōmen Carŏlus (ou Carŏlō).

Eu chamo-me Carlos.

Tibi est nōmen Antōnius (ou Antōniō).

Tu chamas-te António. 
Tibi est nömen Antōnia (ou Antōniae).

Tu chamas-te Antónia.

Illi est nōmen Claudius (ou Claudiō).

Ele chama-se Cláudio.

Illi est nōmen Claudia (ou Claudiae).

Ela chama-se Cláudia.

Huic puĕrō est nōmen Marcus (ou Marcō)

Este rapaz chama-se Marco.

Huic puellae est nōmen Marcia (ou Marciae)

Esta moça chama-se Márcia.

Seruus quidam (serua quaedam), cui (à letra 'para o qual; para a qual') nōmen erat Petrus (ou Petrō; Petra ou Petrae), ...

Certo criado (certa criada), que se chamava Pedro (Petra) ,...

2. pela voz passiva de uocăre acompanhado do nome próprio. Exemplos:

Vocor Carŏlus.

Vocāris Antōnius (Antōnia).

Vocātur Claudius (Claudia).

Hic puer uocātur Marcus.

Haec puella uocatur Marcia.

Seruus quidam, qui uocabātur Petrus, ...

Serua quaedam, quae uocabātur Petra, ...

3. pelo simples ablativo de nōmen (nōminne: ablat. de relação) acompanhado do nome próprio (no mesmo caso do possuidor.) Exemplos:

Puer quidam, nōmìne Marius, ...

Certo rapaz, chamado (ou de nome) Mário,... 
Puella quaedam, nờmine Lucia, ...

Certa rapariga, chamada (ou de nome) Lúcia,...

Video seruum, nōmĭne Petrum.

Estou a ver o criado, chamado Pedro.

Haec uilla est agricŏlae, nōmĭne Crassi.

Esta casa de campo é do agricultor, chamado Crasso.

Discipulae rosas dōnant magistrae, nōmĭne Iuliae.

As alunas oferecem rosas à professora, que se chama Júlia.

\section{EXERCíCIOS :}

Eu chamo-me António (Antónia).

1.

2.

Tu chamas-te Paulo (Paula).

1.

2.

Ele (ela) chama-se Júlio (Júlia).

1.

2.

O agricultor, chamado Pedro, é teu amigo.

3.

Eu estou a ver (= vejo) o agricultor, chamado Pedro, que é nosso amigo.

3.

Certo homem, que se chamava Luciano,...

1.

2. 
A senhora (domǐna, ae) repreende (uituperäre) a criada, chamada Lavínia.

1.

2.

3.

Os alunos ofereciam livros (liber, ri) e presentes (dōnum, i) ao professor (magister, ri), que se chamava Marco.

1.

2.

3.

N.B.: Para a expressão intitular (um livro; uma obra literária) usa-se o verbo inscribĕre.

Exemplos:

Hoc epos Aeneis inscribitur.

Este poema épico intitula-se Eneida.

Apud Cicerōnem in ōratiōne quae inscribŭtur Prō Archiā poētā, ...

Em Cícero, no discurso intitulado (= que se intitula) Defesa do poeta Árquias,...

EXERCÍCIO:

Em César (Caesar: acusat. Caesărem), na obra (liber, ri: masculino) intitulada Sobre a guerra gaulesa (Gallicus, $a$, um) lêem-se (= são lidas) as façanhas (vd. p. 84) das (=pelas) tropas romanas na Gália (Gallia, ae). 


\section{Pullus ad margaritam}

Aliquandō gallus et gallina et pullus ēscam quaerēbant ${ }^{1}$ : gallus aream perlustrans inuěnit granum triť̌ci, quod statim uorat; gallīna brassǐcam in hortō uellĭcans repěrit ērūcam, quam prōtŭnus glutit; pullus in sterquilīnō scabēns ēruit margarìtam et eam capiēns: « $\overline{0}$ margarīta,» inquit, "pulchra pretiōsissimaque es: mihi autem, cui cibus est multō potior, nihưli es!»

1 Vid. p. 23, última linha.

\section{VOCABULÁRIO}

aliquandō: certa vez

area, ae: eira

autem: contudo

brassǐca, ae: couve

capiēns, entis ( + acusat.): que

agarra (em); pegando (em)

cibus, i: comida

cui (dat. sing. do pron. relat.): para quem

ërūca, ae: lagarta

ēruěre: desenterrar

glutīre: engolir

granum, i: grão

inuenīe: achar

margarita, ae: pérola

mihi (dat. sing. do pron. pessoal

da $1 .{ }^{a}$ p. sing.): para mim

nihìlum, i: coisa nenhuma

nihŭli esse: não valer mesmo nada perlustrans, antis: que percorre, ao percorrer

potior, ius: mais poderoso multō potior: bem mais importante

pretiōsissimus, a, um: muito valioso; de grande valor

prōtǐnus: sem demora

quam (acusat. sing. fem. do pron. relat.): a qual; que

quod (acusat. sing. neutro do pron. relat.): o qual; que

reperīe: descobrir

scabēns, entis: que esgaravata;

ao esgaravatar

statim: imediatamente; logo

sterquilinum, i: estrumeira

tritǐcum, i: trigo

uellǐcans, antis: que debica; ao debicar

uorāre: tragar 


\section{CONCRETISMO E SEMÂNTICA}

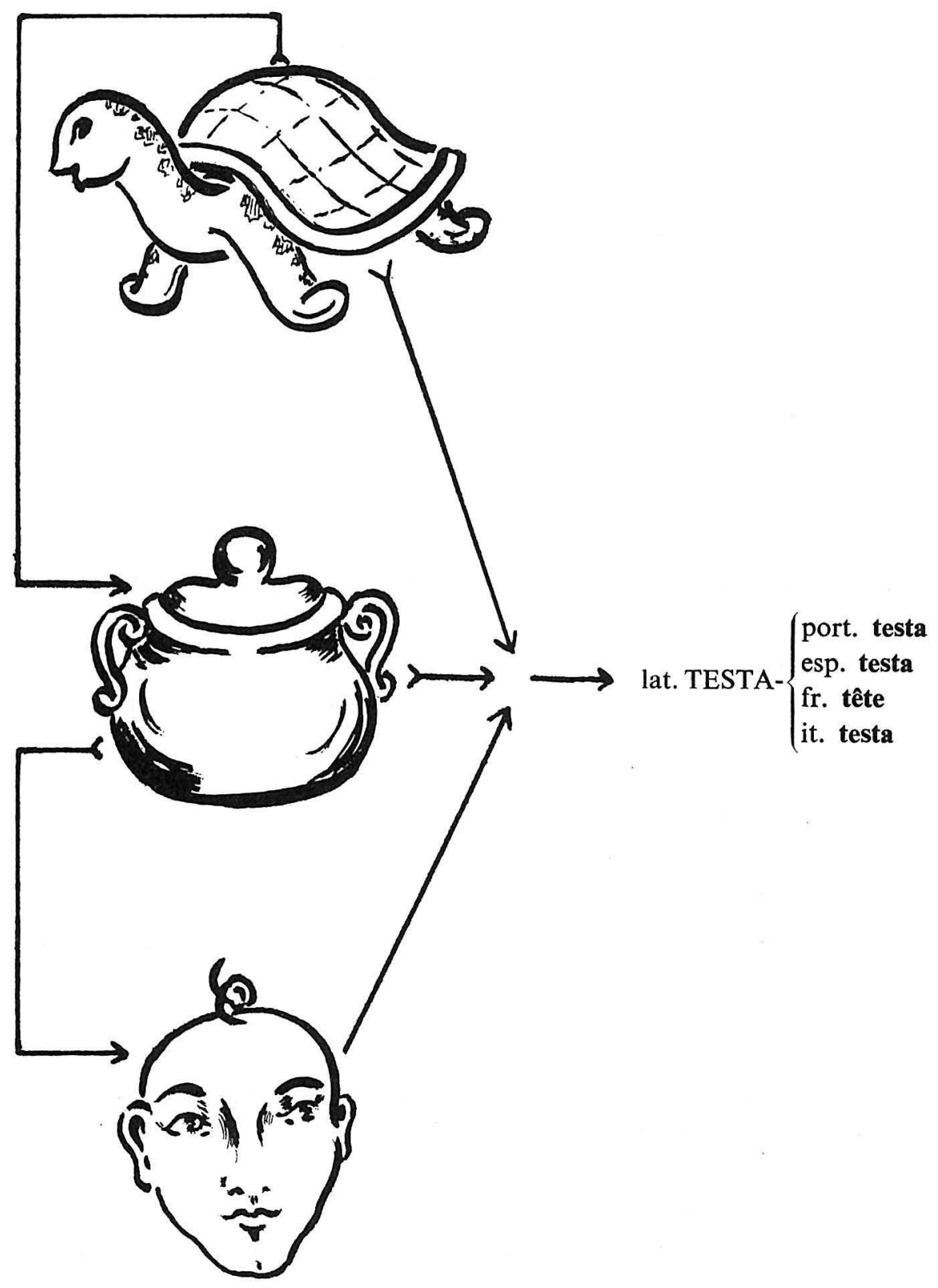


«A prendre les choses en gros, on est amené à reconnaître que l'aspect concret se manifeste surtout dans le langage des non-cultivés, des mentalement inférieurs, tandis que l'aspect abstrait caractérise plutôt celui des civilisés, des évolués, des favorisés de la culture.»

J. Marouzeau

\section{CONCRETO $\longrightarrow$ ABSTRACTO}

uita hominum $=\mathrm{a}$ vida dos homens $=\mathrm{a}$ vida HUMANA

dux Rōmanōrum $=\mathrm{o}$ general dos Romanos $=\mathrm{o}$ general ROMANO

cōnsuētūdō iudiciōrum $=\mathrm{o}$ costume dos tribunais $=\mathrm{a}$ praxe JUDICIÁRIA studia litterārum $=$ os estudos das letras $=$ os estudos LITERÁRIOS

rēs $\left\{\begin{array}{l}\text { nouae }=\text { as coisas novas }=\text { a REVOLUÇÃO } \\ \text { gestae }=\text { as coisas executadas = a HISTÓRIA } ; \text { as FAÇANHAS } \\ \text { diuinae }=\text { as coisas divinas }=\text { o CULTO RELIGIOSO } \\ \text { secundae }=\text { as coisas prósperas = a PROSPERIDADE; os êxITOS } \\ \text { aduersae }=\text { as coisas adversas }=\text { a ADVERSIDADE; OS INSUCESSOS }\end{array}\right.$

aes, aeris bronze:

aestimāre 'avaliar em bronze' > estimar (= avaliar, calcular, apreciar)

calcŭlus, i pequena pedra:

calculāre 'contar por meio de pequenas pedras' $>$ calcular (= contar, conjecturar)

pondus, ponděris peso (da balança):

ponderăre 'pesar' > ponderar (= pesar; avaliar maduramente; apreciar; reflectir, meditar) 
sidus, sidĕris astro:

considerāre 'contemplar os astros' > considerar (= examinar atentamente; apreciar; respeitar; calcular)

candĭdum, i branco brilhante:

candidātus 'concorrente a um cargo público, revestido de toga especialmente embranquecida a giz' > candidato

fiscus, i cesto para prensar uvas e azeitonas $\rightarrow$ cesto para guardar dinheiro $\rightarrow$ rendimentos do Estado destinados à manutenção do Imperador $\rightarrow$ tesouro público $>$ fisco (cf. fiscal, fiscalizar, etc.)

lira, ae sulco do arado:

dēlirāre 'sair do sulco da charrua' $>$ delirar

riuus, i ribeiro:

riuālis 'habitante das margens do mesmo curso de água' $>$ rival.

opportūnus (uentus) (vento) que impele para o porto $\rightarrow$ favorável $>$ oportuno.

prōmulgāre ordenhar; espremer; publicar > promulgar (uma lei)

\section{BIBLIOGRAFIA}

J. Marouzeau, Quelques aspects de la formation du latin littéraire. Paris, C. Klincksieck, 1949, pp. 107-124 («La conquête de l'abstrait»).

Id., «Naissance d'abstraits» in Humanitas, vol. V da nova série, 1956, pp. 148-150. 
EXERCÍCIOS DE RECAPITULAÇÃO

\section{Dei Rōmāni}

Antiqui Rōmāni multōs deōs et deas habēbant. Deōs enim in

caelō, in terra, in agris, in frumentō (nos cereais), in siluis, in undis

et in fluuiōrum aquā uidēbant. Erant magni et parui dei. Inter

magnōs deōs primus erat Iuppĭter, deōrum et deārum pater, qui in

caelō habitābat et fulmĭne (com o raio) malōs terrēbat. Erat

Neptūnō imperium aquārum, nōn sōlum Oceăni sed etiam fluuiōrum.

Iunō, Venus, Cerēs, Minerua et Diāna magnae deae erant; Mars,

Mercurius, Vulcānus, Apollo erant magni dei.

Iunō Iouis (de Júpiter) uxor (esposa) erat rēgīna et deōrum et

deārum. Matrimōniis praeĕrat (presidia) et a Rōmānis matrōnis 


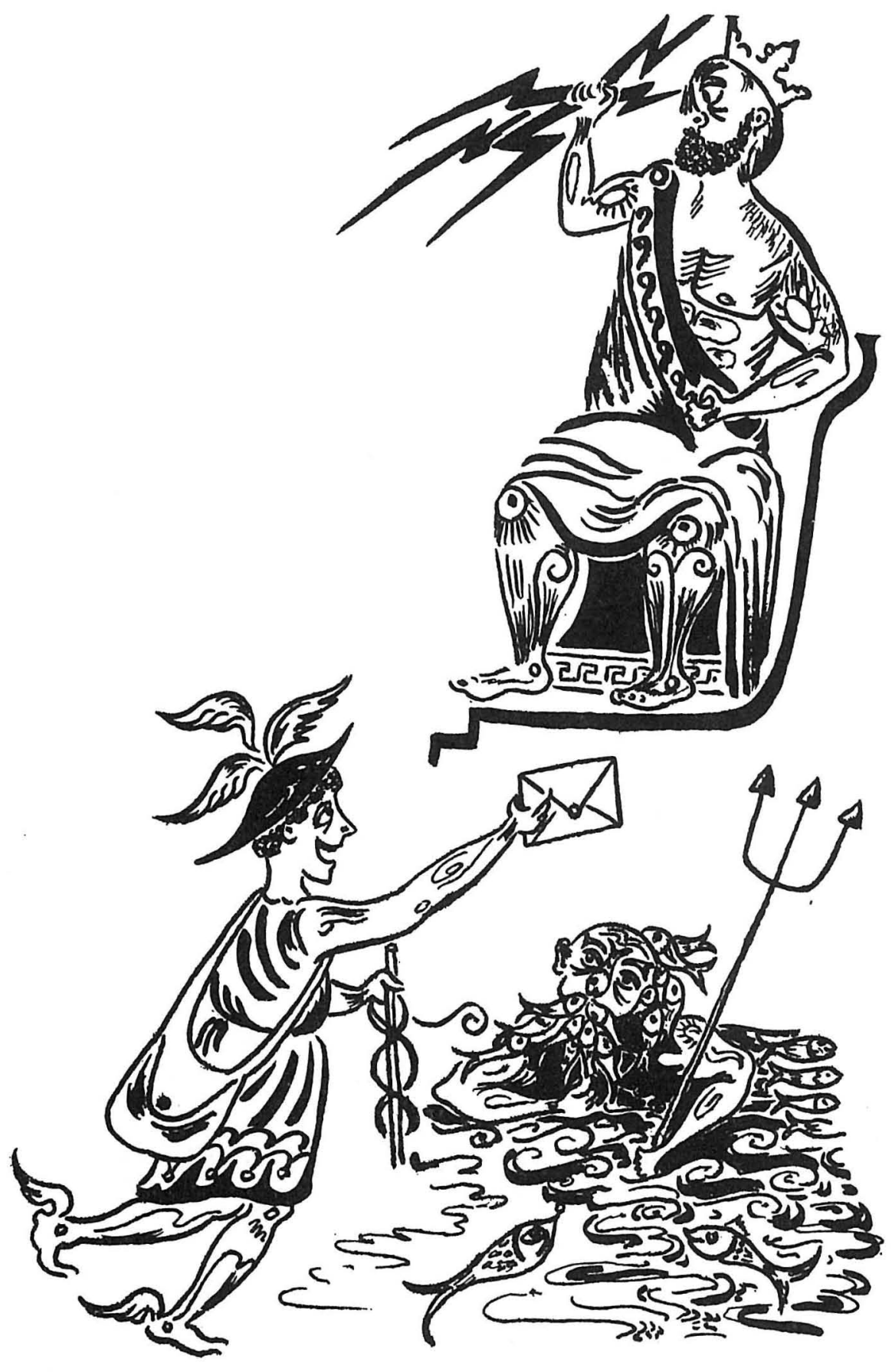




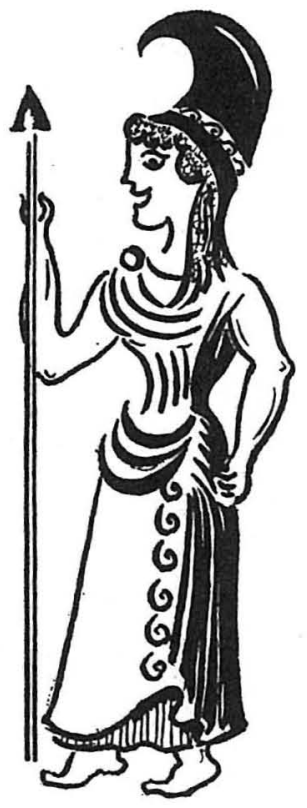

colēbātur. Venus erat deārum pul-

cherrı̌ma et a Marte, deō belli,

amabātur. Venus autem uxor Vulcā-

ni, dei ignis (do fogo), erat. Cerēs

dea frumenti erat, Minerua dea

sapientiae et Diāna dea siluārum.

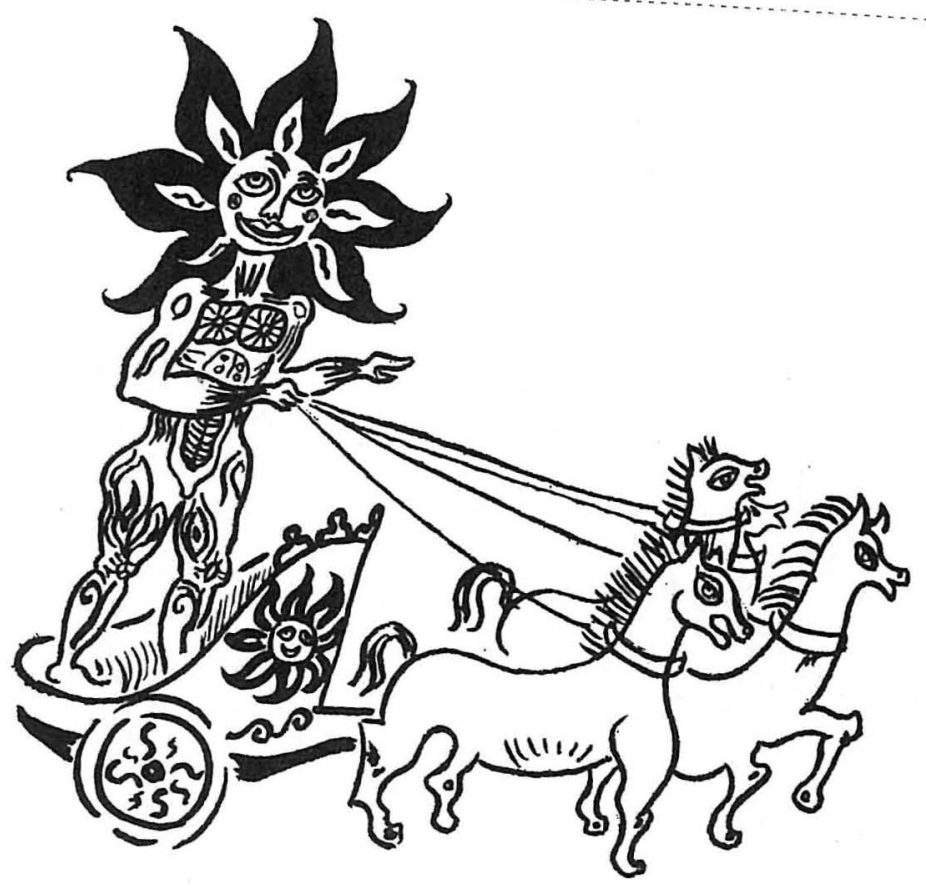


Mercurius erat celer (veloz) nuntius deōrum. Apollo, pulcher

deus, erat Iouis filius et medicinae ac musǐcae praeěrat; deus ōra-

culōrum quoque erat. Vinum dōnum Bacchi est. Nam Bacchus

deus uini erat. Aeŏlus uentōrum deus erat.

Erant etiam parui dei et paruae deae: Larēs, Penātēs, Vesta, etc.

In Graecia et in Italia magna templa deōrum atque deārum

erant. In templis pulchrae deōrum statuae erant.

\section{QUESTIONÁRIO}

- Vbi dei habitābant?

- Quis erat Iupprter?

- Erantne magni et parui dei?

- Neptunusne in caelō habitābat?

- Nōnne Iunō et Venus erant deae?

- Nōnne Iunō Iouis uxor erat?

- Num Mercurius erat tardus (lento) nuntius deōrum?

- Num Mars erat Venĕris uir?

- Minerua erat magna an parua dea?

- Iunō matrimōniis praeĕrat an nōn? 


\section{Verta para latim}

Os Gregos e os Romanos tinham (esse + dat.: vd. p. 77, 2) muitos deuses e deusas, que (qui) habitavam no Olimpo (Olympus, $i$ ), no Oceano, nos bosques, nas águas dos rios e nas profundezas da terra (sub + abl. de altă terră). Júpiter, deus supremo (summus, $a, u m$ ), tinha o domínio (imperāre + dat.) do céu, Neptuno, do Oceano, e Plutão (Plutō), dos Infernos (Inferni, ōrum).

Nos bosques habitavam Pã (Pan) e os Faunos (Faunus, $i$ ) também (quoque) chamados Silvanos (Siluānus, i) -, que protegiam (adesse + dat.) as pastagens (pascuum, i). Pã, divindade (= deus) travessa (lasciuus, a, um), gostava de perseguir (exagitāre) as Ninfas (nympha, qe) em pânico (pauidus, $a$, um): na verdade, ele tinha a feia aparência (turpem speciem habēre + genit.) de um bode (hircus, i).

Faune, Nympharum fugientium amator.

Horácio, Odes, III, xviii, 1.

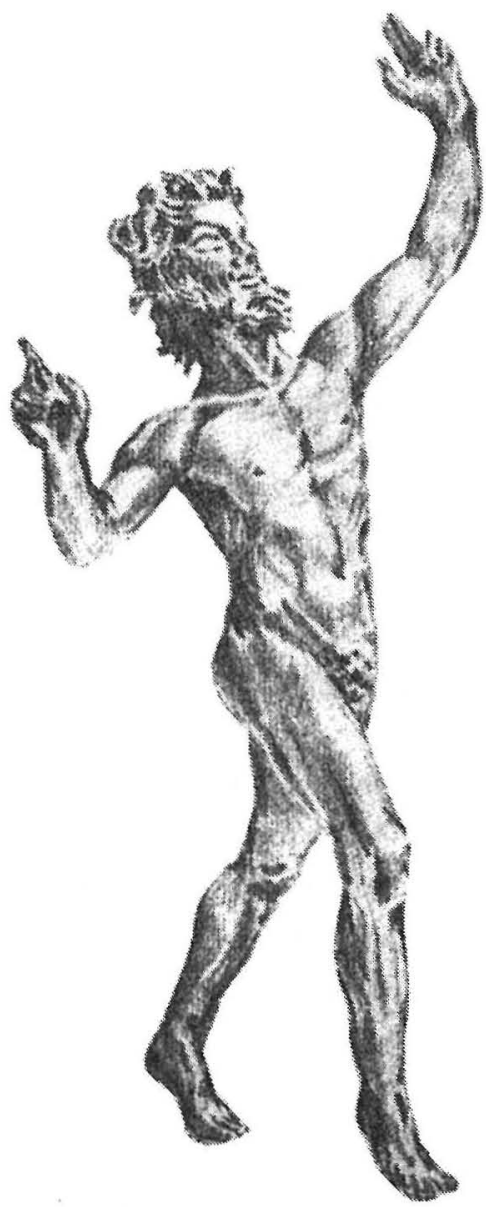


QUINTA DECLINAÇÃO: apenas substantivos, na quase totalidade FEMININOS

N.B.:

diēs 'o dia $\left\{\begin{array}{l}\text { no sing. - masculino ou feminino } \\ \text { no } p l \text { - - masculino }\end{array}\right.$

meridiēs 'o meio-dia' - masculino

Singular

N. rēs

V. rēs

Ac. rĕm

G. reī

D. reì

Ab. rē

\section{Plural}

N. rēs

V. rēs

Ac. rēs

G. rērum

D. rēbus

Ab. rēbus
Singular

N. diēs

V.

Ac.

G.

D.

Ab.

\section{Plural}

N.

$\mathrm{V}$.

Ac.

G.

D.

Ab. 
N.B.:

RES e DIES são os únicos substantivos de tema em $e$ que têm todos os casos do plural.

Usam-se apenas no nominativo e acusativo do plural:

aciēs, ei: o gume

effigiēs, ei : a imagem

faciēs, ei: $o$ rosto

speciēs, ei: a aparência

EXERCÍCIO:

Declinação de rēspublića, reipublićcae: 'a república; o estado; a política; o governo; o poder supremo'

Singular

N. rēspublǐca

V.

Ac.

G.

D.

Ab.

EXERCÍCIOS DE APLICAÇÃO

Rēs Rōmānae magnae erant.

Cōpiis Rōmanis magnus anı̌mus nōn sōlum in rēbus secundis, sed quoque in rēbus aduersis iněrat (vd. pp. 77, 5, e 84). 
Bella ciuilia reipublǐcae perniciōsa sunt.

Viri, qui in mediā rēpublǐcā uersantur aut rempublǐcam tenent, politǐci dicuntur.

Boni ciuēs, sicut bonae lēgēs, utîlēs rēbus suis publǐcis sunt.

Amīcus meus es, sed nōn consiliōrum in rēpublǐcā socius!

Hebdomădae diērum nōmǐna

Hebdomăda est Graecum uocabŭlum a Rōmānis dētortum

(importado); Lusitānum autem nōmen semana dē linguā Latinā

cadit (provém).

Apud antiquōs Rōmānōs nōmĭna diērum erant: diēs Sōlis, dies 
Lunae, dies Martis, dies Mercurii, dies Iouis, dies Veněris, dies

Saturni. Haec sunt pagāna nōmǐna.

Apud nōs, qui nunc in Lusitania habitāmus, diērum nōmǐna

sunt: domingo ( $<$ diēs dominǐcus), segunda-feira ( $<$ secunda fēria),

terça-feira ( $<$ tertia fēria), quarta-feira ( $<$ quarta fēria), quinta-

-feira $(<$ quinta fēria), sexta-feira $(<$ sexta fēria) et sábado ( $<$ sabbă-

tum). Primus igitur hebdomădae diēs dominǐcus dicĭtur; qui post

(a seguir) sequǐtur, secunda fēria; et sic deinceps (assim por diante).

Haec sunt uerba a catholĩcā ecclēsiā conficta (criados). Galli autem, cum hŏdiē dicunt lundi, mardi, etc., nōmĭna diērum dē diē Lunae, de die Martis, etc., dētorquent (derivam). Sic quoque faciunt Hispāni atque Ităli. 


\section{CONJUGAÇÃO VERBAL}

\section{Futuro imperfeito}

\section{Verbo ESSE:}
erō
eris
erit
erĭmus
eritis
erunt

Voz activa

laudā - bō

laudā - bi - s

laudā - bi - t

lauda - bŭ - mus

lauda - br̆ - tis

laudā - bu - nt
Voz passiva

laudā - bǒ - r

lauda - bě - ris

lauda - bi - tur

lauda - bì - mur

lauda - bi - minni

lauda - bu - ntur

monēbō

monēbŏr

$$
\begin{aligned}
& \text { reg - a - r } \\
& \text { reg - } \overline{\mathrm{e}}-\mathrm{ris} \\
& \text { reg - } \overline{\mathrm{e}}-\mathrm{tur} \\
& \text { reg - } \overline{\mathrm{e}}-\mathrm{mur} \\
& \text { reg - } \overline{\mathrm{e}}-\mathrm{minni} \\
& \text { reg - e - ntur }
\end{aligned}
$$


capiam

capiar

audiam

audiar

EXERCÍCIOS DE APLICAÇÃO: temas em $e$ e fut. imperfeito

O estado romano (pl. de rēs Rōmāna) há-de ser grande.

Tu terás (vd. p. 77, 2) êxitos e insucessos (vd. p. 84).

Os Faunos perseguirão as ninfas através dos bosques.

Vocês hão-de gostar da vida do campo e hão-de dedicar-se inteiramente (sē tötum dedère + dat.) à agricultura (rēs rustǐca).

António há-de aumentar (augēre) a sua fortuna (rēs). 
Os poetas hão-de cantar (canĕre) os feitos (pl. de rēs) das tropas romanas.

O advogado (patrōnus, i) há-de defender (dicĕre) a causa (rēs) perante (vd. p. 42,1) o povo.

Que (quam) governo teremos nós?

Havemos de seguir (studēre + dat.) o partido (pl. de rēs) de Gaio Pompeio (Gaius, ii; Pompeius, ii).

Catilina há-de lançar mão (caperre + acusat.) do poder supremo.

Vou escrever (scriberre) as façanhas (vd. p. 84) dos Gregos (N.B.: verta dos Gregos por um compl. agente da passiva).

\section{RECITAÇÃO}

Omnia uanitas

Iste mundus

furibundus

falsa praestat gaudia, quae dēfluunt 1

et dēcurrunt ceu ${ }^{2}$ campi lilia.

\section{Tudo é vão}

Este mundo,

furibundo, mostra-nos falsos delírios, que se esvaem e se escapam como dos campos os lírios.

\section{(dos Carmina Burāna)}

1 Leia-se com o acento na penúltima sílaba para rimar com decurrunt.

2 Pronuncie-se como dissílabo. 
TERCEIRA DECLINAÇÃO: masculinos, femininos e neutros

I - Temas em consoante.

II - Temas em -ii.

I - Temas em consoante: IMPARISSILÁBICOS (número desigual de sílabas no nominativo e genitivo do singular)

\section{Singular}

N. -s ou só o tema

V. " " " "

Ac. -ĕm

G. -is

D. $-i$

Ab. -ě

\section{Plural}

-ès

)>

)>

-um

-íbus

)

EX E M P L O S

a) Sigmáticos:

rēx, rēgis (tema rēg-) rei

\section{Singular}

N. $\operatorname{rēx}(<*$ rēg- + s $)$

V. rēx

Ac. rēgěm

G. rēgis

D. rēgì

Ab. rēgě
Plural

rēgēs

rēgēs

rēgēs

rēgum

rēgǐbus

rēgĭbus 
dux, ducis (tema duc-) condutor; guia; general

\section{Singular}

Plural

N. dux $(<*$ duc- $+s)$

V.

Ac.

G.

D.

Ab.

benignǐtas, benignitātis (tema benignitāt-) indulgência

Singular

Plural

$\mathrm{N}$. benignĭtas $(<*$ benignitat- $+s)$

V.

Ac.

G.

D.

Ab.

eques, equitis (tema equit-) cavaleiro

\section{Singular}

Plural

N.

V.

Ac.

G.

D.

Ab. 


\section{b) Assigmáticos:}

cōnsul, cōnsŭlis (tema cōnsŭl-) cônsul

\section{Singular}

Plural

N.

V.

Ac.

G.

D.

Ab.

leō, leōnis (tema leōn-) leão

N. leō $\left(<{ }^{*}\right.$ leōn $)$

V.

Ac.

G.

D.

Ab.

honōs ou honŏr, honōris (tema honōs-) honra

Em posição intervocálica, $\mathbf{s}>r$ (rotacismo). Seguidamente, o $\mathbf{r}$ resultante do $\mathbf{s}$ estendeu-se ao nominativo/vocativo do singular (analogia): daí as formas honōs (mais antiga) e honŏr (mais recente).

N.

V.

Ac.

G.

D.

Ab. 
Decline:

\section{a) Sigmáticos :}

apex, apĭcis ponta; cimo

auceps, aucĭpis passarinheiro

bonìtas, bonitātis bondade; ternura

carı̌tas, caritātis amor; afeição grex, gregis rebanho

iudex, iudǐcis juiz

lapis, lapĭdis pedra

lēx, lēgis lei nepōs, nepōtis neto

palus, palūdis pântano

pēs, pědis $p e ́$

piětas, pietātis devoção; piedade princeps, princǐpis o principal ( = chefe; soberano; principe; etc.)

uirtus, uirtūtis virtude; valor

\section{b) Assigmáticos :}

arbor, ŏris árvore

auctiō, auctiōnis leilão

factiō, factiōnis conduta; partido político

frater, fratris irmão

flōs, flōris flor

homō, hominnis homem

lectiō, lectiōnis escolha; eleição

mater, matris mãe

mulier, muliěris mulher pater, patris pai

soror, sorōris irmã

stupor, stupōris estupefaç̧ão;

pasmo; estupidez

tepor, tepōris calor tépido; tem-

peratura amena

timor, timōris receio; medo

uirgō, innis donzela; jovem $(=: m u-$ lher nova)

N.B.: Iuppĭter (ou Iūpĭter), Iouis Júpiter

$\mathrm{N}$. Iuppiter

V. »

Ac. Iouem

G. Iouis

D. Ioui

Ab. Ioue 


\section{Dè Ioue}

Saturnus Vrăni filius uxōrem habēbat Rhēam. Erat autem deus crudēlissĭmus: nam liběrōs uorābat, ubi primum Rhēa eōs ēdēbat. Quā dē causā Rhēa dolēbat et saepe liběrōs seruāre cōnātur. Iouem tandem ēdit et prō eō lapĭdem Saturnō dat. Saturnus nōn diffīdēns dolōsae uxōri auǐdus eam uorat. Rhēa ilǐcō Iouem occultat in insǔlā Crētā, ubi Curētēs, fidi Rhēae sacerdōtēs, circa paruŭlum deum stabant cantantēs ac cymbăla quatientēs: sic Saturnus eius uagitus nōn audiēbat.

\section{VOCABULÁRIO}

ac (antes de consoante; atque, lapis, İdis: pedra antes de vogal): $e$ occultāre: esconder auĭdus, a, um: ávido paruŭlus, a, um: pequenino cantans, antis: cantando; a cantar prō [+ ablat.]: em vez de cōnāri [só forma passiva]: tentar quatiēns, entis: que bate; a tocar Crēta, ae: Creta Rhēa, ae: Reia

Curētēs, um: Curetes sacerdōs, ōtis: sacerdote cymbălum, i: címbalo saepe: muitas vezes diffīdēns, entis [+ dat.]: que desSaturnus, i: Saturno confia de; nōn diffīdēns: sem desconfiar dolēre: sofrer dolōsus, a, um: manhoso seruāre: salvar stāre: estar (de pé); manter-se tandem: por fim uagitus, us: vagido ēdĕre: dar à luz ubi primum: assim que; mal fidus, a, um: fiel; leal uorāre: devorar; engolir ilǐcō: sem demora Vrănus, i: Úrano 
TERCEIRA DECLINAÇÃO (cont.):

Il - Temas em -i-: PARISSILÁBICOS (número igual de sílabas no nominativo e genitivo do singular)

ciuis, ciuis (tema ciui-) cidadão

$\begin{array}{ll}\text { Singular } & \text { Plural } \\ \text { N. ciuis } & \text { ciuēs } \\ \text { V. ciuis } & \text { ciuēs } \\ \text { Ac. ciuěm } & \text { ciuēs } \\ \text { G. ciuis } & \text { ciuium } \\ \text { D. ciui } & \text { ciū̌bus } \\ \text { Ab. ciuě } & \text { ciư̌bus }\end{array}$

aedēs (ou aedis), aedis (tema aedi-) templo; no pl. CASA

Singular

N.

V.

Ac.

G.

D.

Ab.
Plural

aedium 
N.B.:

Há alguns temas em -i- que são falsos imparissilábicos. Assim:

*gentis $>$ *gents $>$ gēns 'gente; estirpe; família; no pl. povos' *urbis > urbs 'cidade'

gēns, gentis (tema genti-)

Singular

Plural

N.

V.

Ac.

G.

D.

Ab.

urbs, urbis (tema urbi-)

Singular

Plural

N.

V.

Ac.

G.

D.

Ab. 
Decline:

aedilis, aedilis edil (magistrado linter, lintris canoa municipal) nauis, is barco; navio

auis, auis ave nubēs, nubis nuvem

caedēs, caedis corte; assassinio sēdēs, sēdis assento (banco, cacollis, collis outeiro deira, trono)

famēs, is fome ouis, ouis ovelha

finis, finis fronteira; fim uenter, uentris ventre imber, imbris chuva uter, utris odre

N.B.:

uis, uis a força

$\begin{array}{ll}\text { Singular } & \text { Plural } \\ \text { N. uis } & \text { uirēs } \\ \text { V. uis } & \text { uirēs } \\ \text { Ac. uim } & \text { uirēs } \\ \text { G. uis } & \text { uirium } \\ \text { D. ui } & \text { uirřbus } \\ \text { Ab. ui } & \text { uirřbus }\end{array}$

Este substantivo tem, no singular, o acusativo terminado em -im e o ablativo em -i.

Apresentam as mesmas particularidades alguns outros substantivos, como, p. ex., febris 'a febre', puppis 'a popa (de um navio)', sitis 'a sede', turris 'a torre', tussis 'a tosse', e ainda os nomes próprios Hispălis 'Híspalis (act. Sevilha)', Neapoolis 'Nápoles' e Tiberris 'Tibre (rio de Roma)'. 


\section{Dẽ Iouis pueritiã}

Iuppĭter capram habēbat nutrīcem ${ }^{1}$, Amalthēam nōmĭne. Apēs quoque ei dabant mel, et columbae ambrosiam ē deōrum conuiuiō dēlātam; aliquotiēns aqǔla immānis offerēbat nectar dē caelesti 2 fonte. Sic Iuppìter in insŭlā Crētā adolēscēbat.

Aliquandō puer Iuppĭter, dum pilā ludēbat, cornu 3 blandae Amalthēae rumpit. Tum paruŭlus deus maerēns cornu uocāuit CORNUCōPIAM ${ }^{4}$ et: «Si quis», inquit, «hoc cornu habēbit, longē ditissǐmus erit omnium homĭnum: nam cornu semper erit plēnum omnium fortūnae bonōrum.»

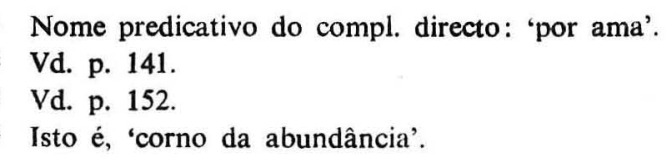

\section{VOCABULÁRIO}

adolēscēre: crescer

aliquandō: um dia; certa vez aliquotiēns: algumas vezes

Amalthēa, ae: Amalteia ambrosia, ae: ambrósia apis, is: abelha aquilla, ae: águia blandus, a, um: meigo bona, örum: bens caelestis, e: celeste capra, ae: cabra conuiuium, ii: festim dēlātus, a, um: trazido ditissimus, a, um: muito rico longẽ ditissimus: de longe o mais rico fōns, fontis: fonte immānis, e: gigantesco luděre: brincar pilā luděre: jogar à bola maerēns, entis: triste; aflito mel, mellis (neutro): mel nectar, ăris (neutro): néctar nutrix, icis: ama (=que amamenta) offerre: oferecer pila, ae: péla; bola pueritia, ae: infância rumpěre: quebrar si: se si quis: se alguém; todo aquele que uocåre: chamar 


\section{IV - DECLINAÇÃO PRONOMINAL \\ (continuação)}

a) PRonome relativo: qui, quae, quod 'que, quem, o qual, (aquele) que'

b) PRONOME INTERROGATIVO: quis ou qui, quae, quid ou quod 'quem? que? qual?'

c) PRONOMES INDEFINIDOS: quis ou qui, quae ou qua, quid ou quod 'alguém, algum'; quidam, quaedam, quiddam ou quoddam 'um certo; um tal'

\section{DECLINAÇÃO}

Singular

a) N. qui
A. quem quam quod
G.
cuius
D. cuì

\section{Plural}

qui quae quae

quōs quās quae

quōrum quārum quōrum quibus

quibus

\section{Singular}
b) N. quis ou qui
quae
quid $o u$ quod
A.
G.
D.

ou

Ab. 


\section{Plural}

N.
A.
G.
D.

Ab.

\section{Singular}

c) N. quis ou qui

quid ou quod

A.

ou

G.

D.

Ab.

\section{Plural}

N.

ou qua

A.

ou

G.

D.

Ab.

OBSERVAÇõEs:

a) O pronome relativo concorda com o seu antecedente em género e número, mas vai para o caso que a sua função sintáctica determinar. 
Exemplos:

Este é o homem que tu viste.

Hic est uir quem uidisti.

Este é o rapaz cujos livros encontrámos.

Hic est puer cuius librōs inuēnìmus.

Esta é a rapariga a quem dei a caneta.

Haec est puella cui calămum dōnāui.

Esta é a mulher que nos espancou (= por quem fomos espancados).

Haec est mulier a qua uerberāti sumus.

\section{Exercícios:}

Estas são as mulheres que tu viste.

Estas são as raparigas cujos livros encontrámos.

Estes são os rapazes aos quais dei as canetas.

Estes são os homens que nos espancaram (= pelos quais...).

b) Pronome interrogativo: as formas quis (nom. masc.) e quid (nom. neutro) são normalmente empregadas como substantivos; as formas qui e quod, como adjectivos.

Exemplos:

— Quis hic est?

- Quem está aqui?

—Quid metuis?

- Que receias?

- Qui deus?

- Que deus?

— Quod templum?

-Que templo? 
c) O pronome indefinido quidam, quaedam, quiddam ou quoddam declina-se como o relativo qui, ao qual se junta o elemento indeclinável -dam. Assim, por exemplo, acusat. do sing. quemdam, quamdam, quiddam ou quoddam.

N.B.:

A expressão Era uma vez... que pode ser vertida pelos advérbios ōlim, aliquandō ou quondam, e o indefinido quidam. Assim, por exemplo:

Ōlim uir quidam filiōs duōs habēbat...

Era uma vez um homem que tinha dois filhos...

Aliquandō mulier quaedam, nōmĭne Claudia, per siluam quamdam iter faciēbat...

Era uma vez uma mulher, chamada Cláudia, que ia através de um bosque...

Nautae quidam ad Crētam quondam nauigābant...

Era uma vez uns marinheiros que se dirigiam a Creta...

Ōlim rēgi cuidam (vd. p. 77, 2) trēs erant filiae...

Era uma vez um rei que tinha três filhas...

\section{Verta para latim:}

Era uma vez um leão que andava à caça (uēnāri: só forma passiva) num bosque...

Era uma vez um lobo que, compelido (compulsus, $a$, um) pela sede (vd. p. 105, N.B.), corria em direcção a um rio... 


\section{Iuppìter Saturnum ẽ rêgnō pellit}

Iuppiter, ut scimus, in insǔlā Crētā adolēscēbat habēns comìtēs ac lusus ${ }^{1}$ partič̄pēs nōn sōlum Amalthēam capram sed etiam Nymphas decentēs. Tandem iam deus ualǐdus ac pulcherrǐmus patrem Saturnum ex Olympō pellit et in eius locum succēdit.

Saturnus ex Olympō pulsus ad Tanum confũgit, qui in ltaliā rēgnābat, et in eius rēgnō sē occultat: quā dē causā Tani rēgnum postea Latium uocābǐtur.

Saturnus gratus, nōn sōlum Ianō dat potestātem tempus 2 praeterĭtum ac futūrum cognoscendi 3 , sed quoque ciuēs docet agrōrum colendōrum ${ }^{4}$ artem, et eius beneficiō cooř̌tur in terris aurea aetas.

1 Vid. p. 151.

2 Vid. p. seguinte.

3 cognoscendi 'de conhecer'.

+ agrorum colendorum 'de cultivar os campos'.

\section{VOCABULÁRIO}

aetas, ātis: idade

aureus, a, um: de ouro

beneficium, ii:favor; serviço (prestado a alguém)

alicuius beneficiō: por mercê de alguém; graças a alguém

comes, Ǐtis: companheiro

confugĕre: refugiar-se

ad alı̆quem confugĕre: refugiar-se junto de alguém cooriri [só forma passiva]: surgir decēns, entis: bem feito; formoso docēre [ + dois acusat.]: ensinar

(alguma coisa a alguém)

gratus, a, um: reconhecido

habēns, entis: que tem; tendo

Latium, ii: Lácio

(i.e., esconderijo; refúgio: cf. latēre 'esconder') locus, i: lugar

lusus, us: brincadeira

memor, ŏris [+ genit.]: lembrado

[de]

occultāre: esconder

partǐceps, ĭpis: participante

pellĕre. expulsar

postea: posteriormente

potestas, ātis: poder; faculdade

praeterĭtus, a, um: passado

pulcherrimus, a, um: muito belo

pulsus, a, um: expulso

scire: saber

succēděre: vir depois

in eius locum succēděre: suceder-lhe

tandem: por fim

ualìdus, a, um: forte; robusto ut: como 
TERCEIRA DECLINAÇÃO (cont.):

\author{
N E U T R O S
}

I - Temas em consoante (imparissilábicos):

$$
\begin{aligned}
& \text { corpus, corpŏris corpo } \\
& \text { tempus, tempŏris tempo } \\
& \text { caput, capǐtis cabeça } \\
& \text { nōmen, nōmǐnis nome }
\end{aligned}
$$

II - Temas em -i- (parissilábicos e falsos imparissilábicos):

$$
\begin{aligned}
& \left({ }^{*} \text { marĭ }>\right) \text { mare, maris mar } \\
& \left({ }^{*} \text { animalı̆ }>\right) \text { animal, animālis animal }
\end{aligned}
$$

N.B.:

Os neutros de tema em -i têm o ABLATIVO DO SINGULAR terminado em $\mathbf{i}$.

E X E M P L O S :

I - Temas em consoante:

\title{
Singular
}

N. corpus

caput

nōmen

V. corpus

Ac. corpus

G. corporris

D. corpŏri

Ab. corpŏre 


\section{Plural}

N. corpŏră

capǐtă

nōmĭnă

V. corpŏră

Ac. corpŏră

G. corpŏrum

D. corporǐbus

Ab. corporĭbus

II - Temas em -i-:

\section{Singular}

N. mare

animal

V. mare

Ac. mare

G. maris

D. mari

Ab, mari

Plural

N. mariă

V. mariă

Ac. mariă

G. marium

D. marǐbus

Ab. marǐbus 
OBSERVAÇÕES À TERCEIRA DECLINAÇÃO

1 - Alguns parissilábicos terminam em -um no genitivo do plural: pater, patris pai . . . . G. Pl. patrum mater, matris mãe . . . . " " matrum frater, fratris irmão . . . . . » $»$ fratrum iuuĕnis, iuuĕnis jovem . . . . " " iuuĕnum senex, senis ancião . . . . . ” » senum canis, canis cão . . . . . " " canum uatēs, uatis vate . . . . . »» uatum

2 - Declinam-se como gẽns, gentis (genitivo do plural em -ium), entre outros, os seguintes imparissilábicos (vide p. 103):
ars, artis arte ...... . G. Pl. artium
arx, arcis cidadela . . . . » $»$ arcium
crux, crucis cruz . . . . . . " » crucium
mōns, montis monte . . . . " " montium
mus, muris rato . . . . . " " murium
nix, niuis neve . . . . . . . » " niuium
nox, noctis noite . . . . . " " noctium

3-Há palavras, nesta declinação, que só se usam no plural, como por exemplo:

faucēs, faucium garganta; corredor

Manēs, Manium os (deuses) Manes

maiōrēs, maiōrum antepassados

Outras há que podem apresentar um significado diferente no plural. Assim:

aedēs, is templo

finis, is fim aedēs, ium casa

finēs, ium território; fronteira 
EXERCÍCIO :

Declinação de iusiurandum, iurisiurandi 'juramento':

\section{Singular}

N.

V.

Ac.

G.

D.

Ab.

Plural

N.

V.

Ac.

G.

D.

Ab.

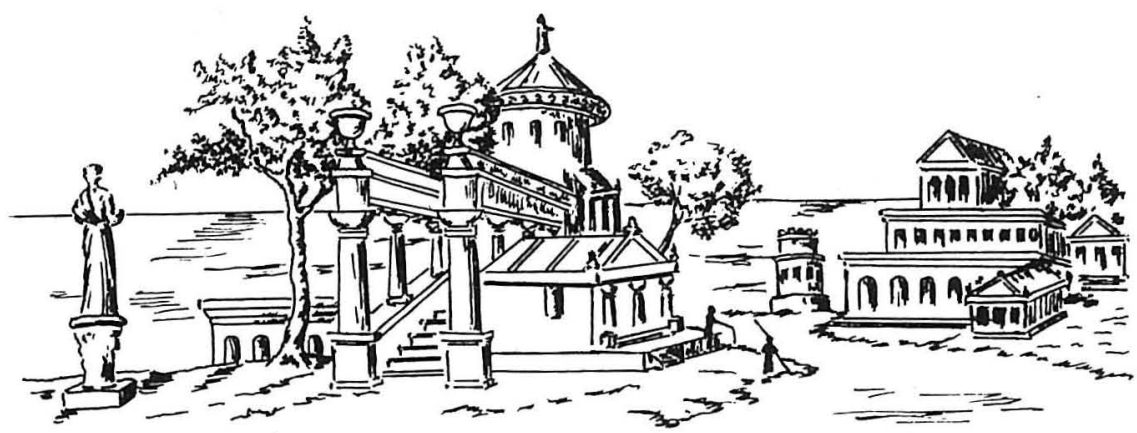

VILLA PROPE MARE

(Desenho inspirado numa pintura de Pompeios) 


\section{Dē aureã aetāte}

Saturni beneficiō, ut dictum est, omnēs homīnēs beatē uiuēbant ac pace fruēbantur, et agri grauĭdis aristis canēbant ${ }^{1}$. Nam uēr erat aeternum placidique ${ }^{2}$ Zephy̆ri ēgelĭdis auris flōrēs ${ }^{3}$ sine sēmǐne natōs mulcēbant; flumina et lactis et nectăris lēnia fluēbant; flauum mel dē arborĭbus stillābat; sine rei militāris usu ${ }^{4}$ gentēs sēcūrae mollia ōtia peragēbant.

Fēlicĭtas autem nunquam permănet. Nam post auream aetātem uita homǐnum ${ }^{5}$ gradātim corrumpitur et tandem in terris cooriuntur et malesuāda famēs et mortifĕri morbi et saeua bella.

Apud Ouidium, in librō qui inscribǐtur Metamorphōsēs, leğtur fabŭla aetātum quattuor: prima, ut supra dixi, fuit aurea; huic subiit argentea; post argenteam aetātem successit aēnea; ultı̆ma fuit ferrea, quae nōn sōlum pudōrem et uērum et fidem fugāuit, sed quoque in eōrum locum apportāuit fraudēs et dolōs et insidias et uim et amōrem scelerātum habendi. ${ }^{6}$ Qua dē causa Astraea, dea iustitiae, terras caede madentēs reliquit.

1 De canëre 'encanecer; branquear': não confundir com canère 'cantar'.

2 Note a enclítica -que 'e'. Outros exemplos:

pater et mater $=$ pater matérque

frater et soror $=$ frater sorórque

filius et filia $=$ filius filiá

puer et puella $=$ puer

seruus et serua $=$ seruus

dominus et domina $=$

dei et deae $=$

flörës... natōs: note o género de flōs.

4 Vd. p. 151.

5 uita hominum: vd. p. 84.

6 amorem scelerātum habendi 'a ânsia criminosa de posse'. 


\section{VOCABULÁRIO}

aēneus, a, um: de bronze

aetas, ātis: idade

aeternus, a, um: perpétuo

apportāre: trazer

argenteus, a, um: de prata

arista, ae: espiga

Astraea, ae: Astreia

aura, ae: brisa

aureus, a, um: de ouro

beatē: feliz ( $=$ com felicidade)

caedēs, is: sangue (derramado)

corrumpĕre: degradar

dicĕre: dizer; pret. perf. ind. dixi dictus, a, um: dito (=que se disse)

ut dictum est: como se disse

dolus, i: artimanha

ëgelǐdus, a, um: tépido

et: $e$

et... et... : não só... mas também...

fabŭla, ae: fábula; mito

fēlicĭtas, ātis: felicidade

ferreus, a, um: de ferro

fidēs, ei: lealdade

flauus, a, um: louro; dourado

fluĕre: fluir; correr (falando de líquidos)

flumen, ǐnis: rio

fraus, dis: fraude

frui (só forma passiva) [+ ablat.]: gozar (de)

fugāre: expulsar

gradātim: pouco a pouco

grauldus, a, um: gordo

insidiae, ārum: ciladas

lac, lactis (neutro): leite

lënis, e: calmo; lento

flumǐna lēnia fluēbant: os rios corriam suavemente locus, i: lugar

madēns, entis: impregnado

malesuādus, a, um: que é mau conselheiro

mollis, e: mole; agradável

molle ōtium: o prazer do ócio

morbus, i: doença

mortĭfer, ěra, ěrum: mortal

(=que causa a morte); fatal

mulcēre: acariciar; afagar

natus, a, um: nascido

nunquam: munca

ōtium, ii: ócio

Ouidius, ii: Ovídio

pax, pacis: paz

peragĕre: concluir

ōtium peragěre: gozar o ócio

permanēre: durar muito

placĭdus, a, um: brando

pudor, ōris: moralidade

quattuor: quatro

relinquĕre: deixar

pret. perf. ind. reliqui

saeuus, a, um: cruel; impiedoso

sēcūrus, a, um: seguro; que está

em segurança

sēmen, ĭnis: semente

sine [- ablat.]: sem

stillāre: gotejar

subire [ + dat.]: suceder (a)

succēdĕre: sobrevir

supra: em cima; antes

usus, us: uso

rei militaris usus: experiência da guerra

uër, uëris (neutro): primavera

uērum, i: verdade

uis, uis: violência 


\section{V - DECLINAÇÃO PRONOMINAL}

(continuação)

PRONOMES PESSOAIS

\section{Singular}

1. $^{a}$ pessoa

2. ${ }^{a}$ pessoa

3. ${ }^{a}$ pessoa

(reflexo)

N. ego

tu

V. -

A. $\mathrm{mē}$

tu

G. mei

tē

sē

tui

suī

D. mihi

tibi

sibi

Ab. mē

tē

sē

\section{Plural}

N. nōs

uōs

V. -

uōs

Como no singular
A. nōs
uōs
G. nostrum ou nostrī
uestrum ou uestri
D. nōbis
uōbis

Ab. nōbis

uōbis

N.B.:

$$
\begin{array}{cr}
\text { mēcum 'comigo' } & \text { nōbiscum 'connosco' } \\
\text { tēcum 'contigo' } & \text { uōbiscum 'convosco' } \\
\text { sēcum 'consigo mesmo' }
\end{array}
$$




\section{EXERCÍCIOS DE REVIS ÃO}

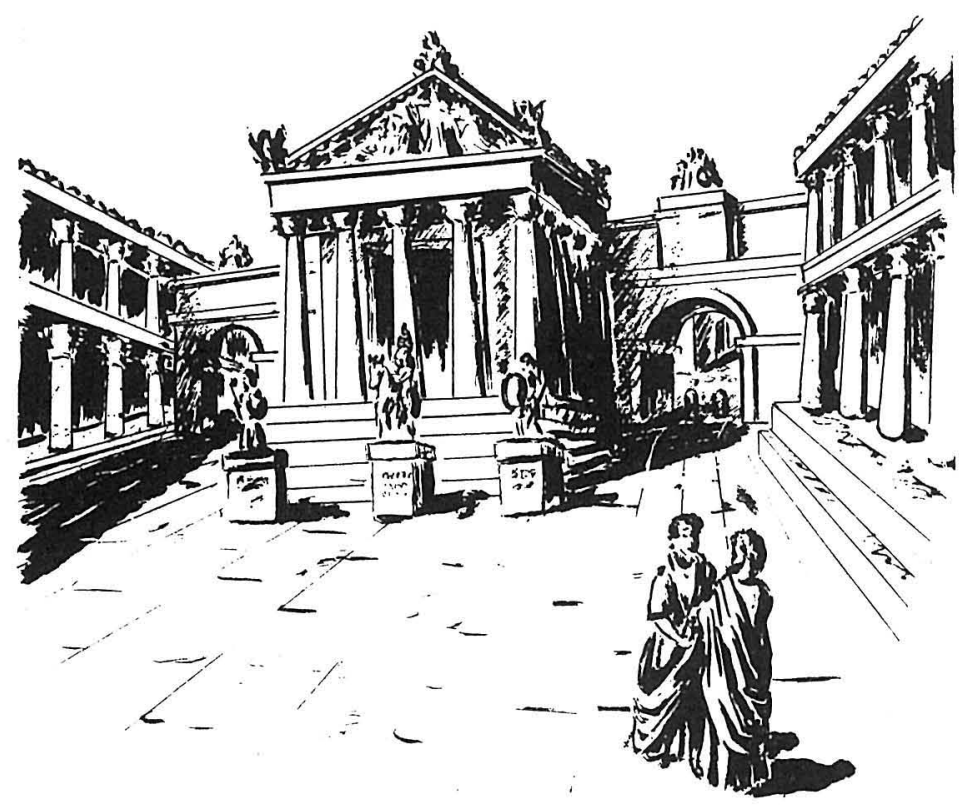

\section{I - In forō}

In urbe Rōmā et aliis oppǐdis semper erat forum, ampla platěa portĭcu circumdăta, ubi nōn erant currus, sed pedĭtēs tantum; ubi homĭnēs conueniēbant, negōtiabantur, litigābant; ubi comitia habēbantur, iudicia exercēbantur, ludi dabantur.

Homīnēs sub portǐcum deambulābant ad pluuiam atque sōlem uitandum, et cum amicis uerba faciēbant.

In forō erant templa, tabernae, thermae, basilǐca et statuae multae, pedestrēs et equestrēs, nōn sōlum Imperatōris, uērum etiam imperialis familiae atque adēō praeclarōrum uirōrum.

Mercatōrēs mercēs emēbant uel uendēbant; ciuēs ōratōrēs ōratiōnēs in rōstris habentēs audiēbant, in pergŭlis pictōrēs et tabŭlas pictas spectābant, in basilǐca litigābant aut negōtia agēbant. Nam forum erat sēdēs uitae urbanae, et ciuilis et commerciālis.

Ibi erant etiam argentarii et uenalicii: argentarii argentariam faciēbant; uenalicii seruōs seruāsque uendēbant.

In forō uictōirae et cladēs a nuntiis nuntiabantur, triumphi agēbantur et ciuēs nuntia dē aliis rēbus audiēbant. 


\section{VOCABULÁRIO}

adeō: até; também

amplus, a, um: vasto

argentaria, ae: casa bancária;

banco - argentariam facĕre:

exercer a profissão de banqueiro

argentarius, ii: banqueiro

basilǐca, ae: basílica (grande edi-

ficio onde funcionavam o tri-

bunal e a bolsa de comércio)

circumdăre: rodear

cladēs, is: desastre; derrota militar comitium, ii: comício

conuenire: reunir-se

currus, us: carro

deambulāre: passear

dare: dar; apresentar

eměre: comprar

etiam: também; ainda

exercēre: realizar

habēre: ter; celebrar; proferir

homō, ǐnis: homem

ibi: ai ; nesse lugar

imperator, ōris: imperador

iudicium, ii: julgamento; tribunal

litigāre: pleitear

mercātor, ōris: negociante

merx, mercis: mercadoria

negōtiāri (só forma passiva): negociar

negōtium, ii: negócio

negōtia agěre: tratar dos negócios

nuntiāre: anunciar

nuntium, ii: notícia

nuntius, ii: mensageiro

oppĭdum, i: cidade (fortificada)

ōratiō, ōnis: discurso

ōratiōnem habēre: discursar ōrātor, ōris: orador; advogado

pedes, ìtis: aquele que vai a pé;

peão

pergŭla, ae: oficina

pictor, ōris: pintor

platĕa, ae; praça pública

portǐcus, us: pórtico: passagem coberta por um tecto apoiado em colunas

praeclārus, a, um: notável, ilustre rōstrum, i: bico (de ave); esporão da proa do navio

pl. rōstra, ōrum: tribuna para os oradores, no foro, ornada de esporões de navios capturados ao inimigo

sēdēs, is: sede; centro

semper: sempre

sōl, sōlis: sol

spectāre: observar

statua, ae: estátua

tabŭla, ae: tábua

tabula picta: quadro (pintado)

tantum: somente, apenas

thermae, arum: banhos; balneário

triumphus, i: triunfo (entrada em

Roma, em solene cortejo, de um general vitorioso)

triumphum agěre: celebrar um triunfo

uenalicius, ii: vendedores de escravos

uerbum, i: palavra

uerba facĕre: falar; conversar uitāre: evitar

ad... uitandum: para se protegerem de...

urbānus, a, um: urbano; civil 


\section{II - Apud Antōnium}

(Vide pág. 58 e ss.)

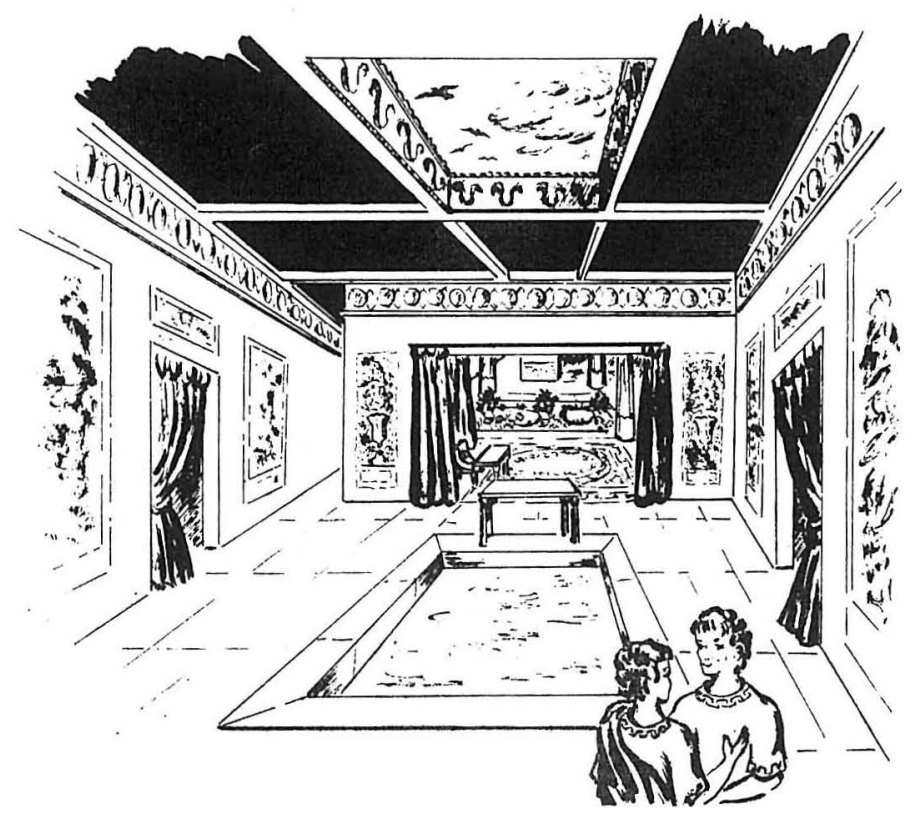

a) IN ATRIŌ

C. Antōnius Pulcher magnas aedēs in urbe Rōmā habĭtat; eius enim pater est diues argentarius qui in forō argentariam habet.

Antōnius, in atriō sedēns apud lararium, amicum suum, Lucium nōmĭne, qui a Pompeiis uenit, exspectat.

Cum Lucius ad Antōnii aedēs aduĕnit, ianuam pulsat. Canis est apud ianuam, sed nōn latrat: nam dormit. Quamquam Cerběrus uocātur, nōn est saeuus: canis est mitis. Ianus ianĭtor ianuam apĕrit. In uestibŭlo, ad sinistram intrantǐbus, canis ingens, catēnā uinctus, in pariěte erat pictus superque quadrātā littěrā scriptum: CAVE CANEM. Deinde Lucius in atrium intrat, ubi est impluuium aquā purā plēnum. Antōnius, ubi primum amīcum cōnspřcit, statim surgit et eum cum gaudiō salūtat: «Hauē, Luci, aduēnisti tandem! Nōn sōlum ego tē exspectābam, sed etiam familia tōta.» Sed Lucius, dē uiā lassus, ēsŭrit et sitit. Quarē Antōnius eum sedēre iubet et parumper quiēscěre. Deinde seruam uocat: «Seruilia, amicus meus ēsŭrit ac sitit: nōbis, amabō, nōnnullas placentas et aquam frigĭdam appōne.» Nunc 
pueri bibunt et omnēs placentas magnā edacitāte edunt. Et Antōnius: «Pater meus,» inquit, «est in forō et mater mea in hortō cum sorōre et hortulānō Hortēnsiō. Nunc ueni et uidē domum nostram. Primō tablinum ac bibliothēcam tibi mōnstrābō; deinde peristȳlum, oecum et triclinium.» Tunc pueri surgunt et per atrium ad bibliothēcam flectuntur.

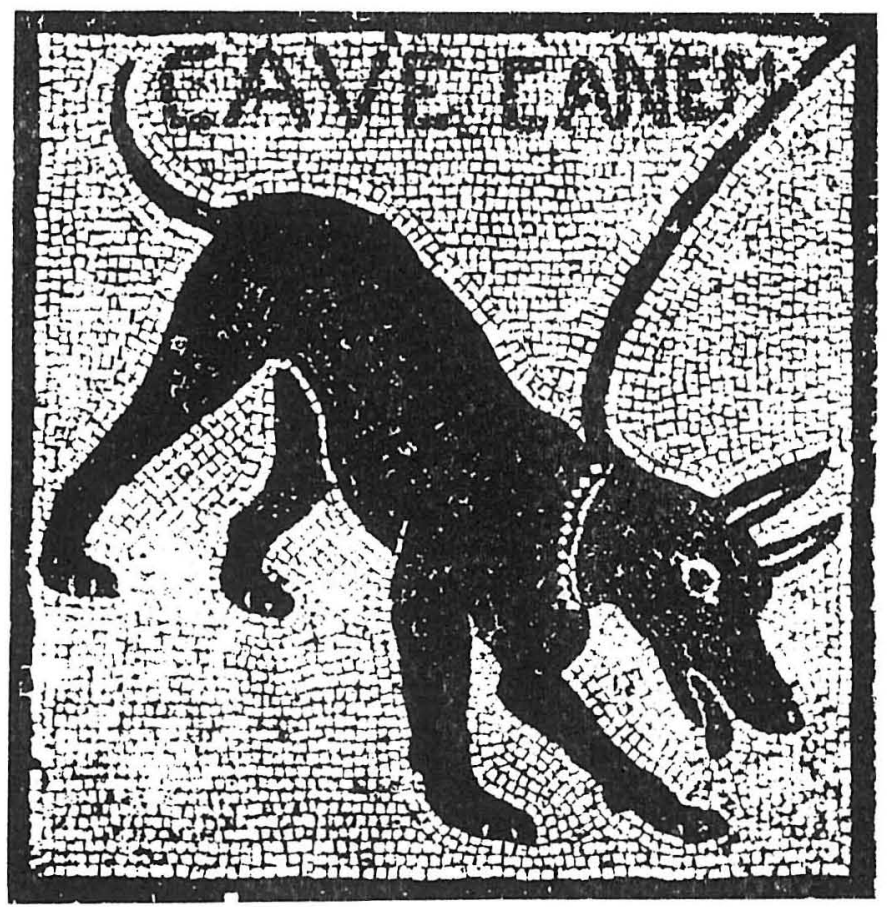

\section{b) IN TABLINŌ}

Ibi nidi tōtōs pariětēs uestiēbant. In singŭlis nidis erant multa uolumǐna chartea et pergamēna. Et Antōnius: «Ecce bibliothēca nostra,» inquit; «librōrum titŭli $\overline{\mathrm{e}}$ uoluminǐbus pendent. $\mathrm{Si}$ quis legĕre uult, librum optātum inuenire faç̌lĕ potest.» Et Lucius: «Hìcne sunt libri tui, Antōni?» «Sunt; in his nidis, laeuā parte, poētas uidēs: Plauti et Terentii comoedias, Catulli epigrammăta uel nugas, Vergilii epos, Horatii carmǐna; in illis nidis, dextrā parte, sunt libri prōsa ōratiōne scripti: Cicerōnis ōratiōnēs, Caesăris libri DĒ Bellō Gallǐcō, Salustii de Coniuratiōne Catilinae, Titi Liuii 
AB VRBE CONDĭTA multaque alia.» Tum Lucius: «Ego librōs prōsā ōratiōne scriptōs libentius legō.» «Ego,» Antōnius inquit, "carmĭna libentius legō: nōs ergō eōsdem librōs nōn amāmus. Nunc tē ducam ad peristȳlum.» Intěrim M. Antōnius Fēlix, Antōnii pater, in tablinum intrat, et Antōnius: «Hauē,» inquit, "pater, hŏdiē sērō ē forō uēnisti!» «Ita est; nam senātum frequentem habuĭmus.» Sed Antōnius Fēlix Lucium animaduertit et eum salūtat et amplectǐtur: "Hauē, Luci, peropportūnē aduěnis: nam in ultimis diēbus huius mēnsis rus proficiscēmur, ad uillam quam Arpini habeō; aestāte Rōma, sicut Pompeii, nōn est amoena!» Et ad filium: «Vbi est mater tua?» «In hortō, crēdō, cum sorōre meā et hortulānō.» Antōnius Fēlix seruum uocat: «Vini, huc ueni.» Vinius nōn uenit: prō eō uenit Seruilia. Tunc dominus: «Tē nōn uocāui, Seruilia. Vbi est Vinius?» «In cella uinaria, ut solet: ēbrius stertit.» «Furcǐfer! Seruilia, domǐnam ad cēnam ēuǒca, nam omnēs ēsurĭmus. Ei dic Lucium iam hīc esse. Dē Viniō post cēnam uidēbō...» Antōnius Fêlix cum filiō et Luciō per peristȳlum, columnis circumdătum, in triclinium sē cōnfert.

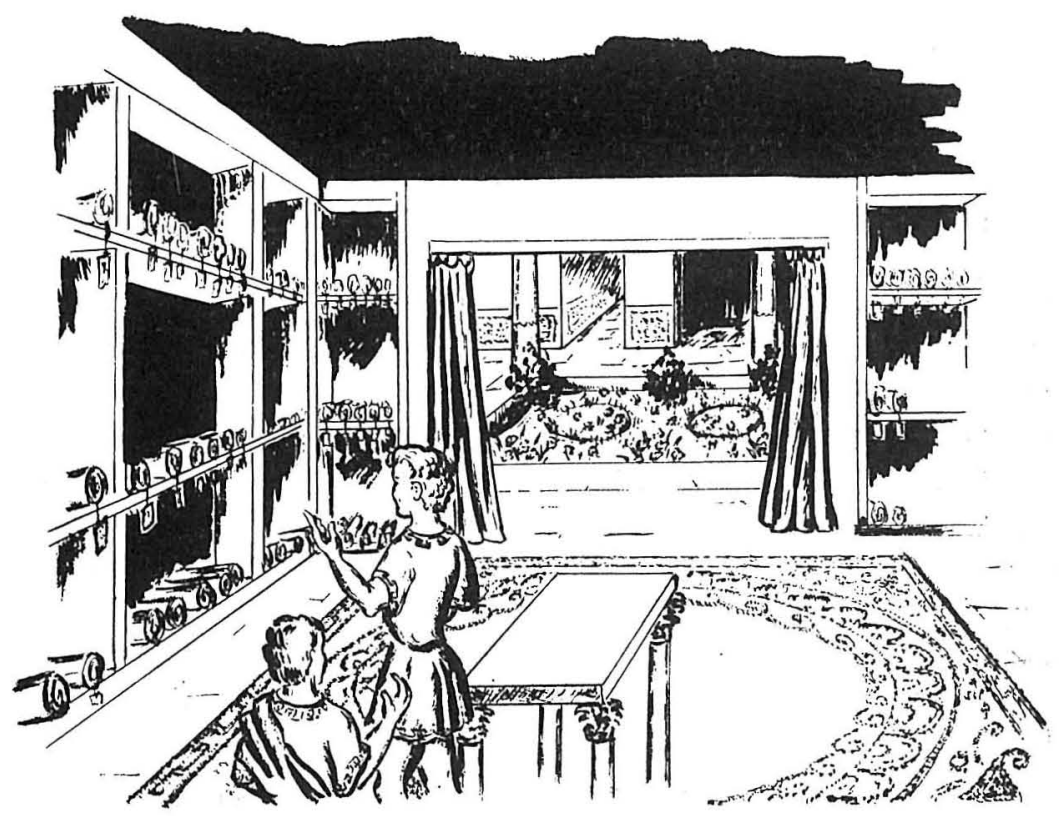




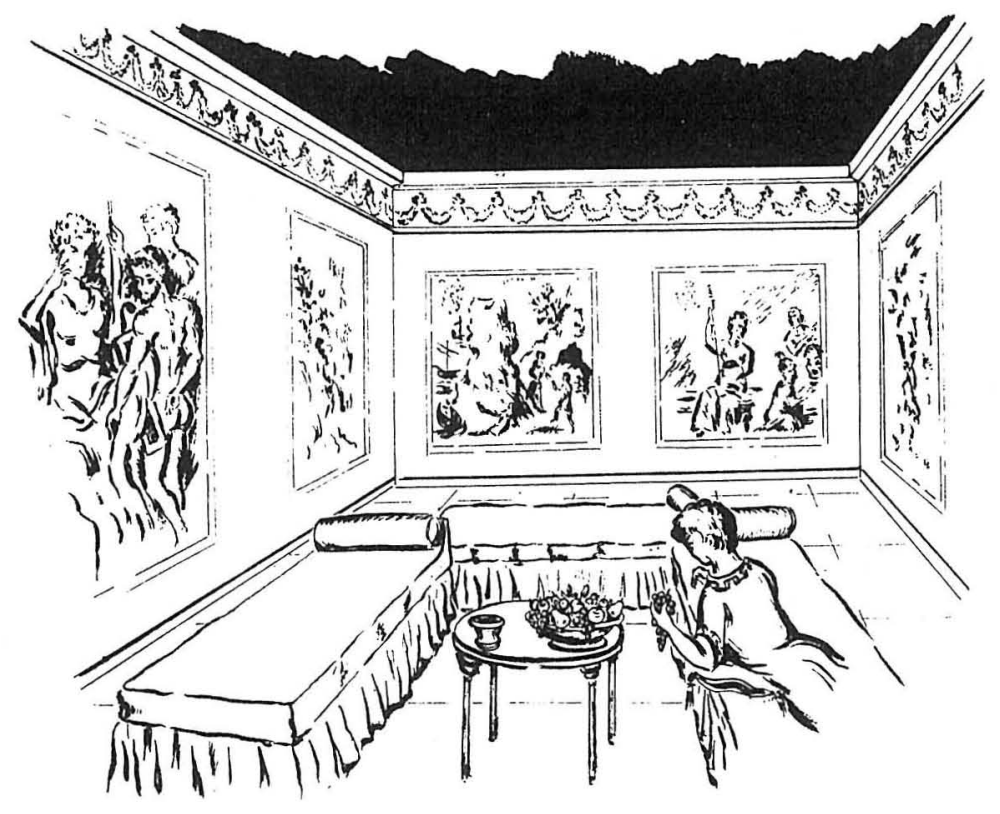

\section{c) IN TRICLINIŌ}

Nunc familia tōta in triclinium conuěnit. Auus et auia in summō lectō discumbunt, pater et mater in mediō, liběri et Lucius in imō. Domĭnus autem seruōrum opěrā nōn est laetus: Vinius crēbrō pōcŭlum tangit; Seruilia est garrŭla; Congriō coquus, edax atque tardus; hortulănus, piger. "At uōbis male sit, mali serui!» domĭnus muttit, et, dum cēnam exspectat, uinum gustat: «Hercle, hoc nōn est uinum, sed pōsca!» Ecce Seruilia apportat uini cadum et: «Vicīnus noster,» inquit, «tibi mittit hunc cadum uini in aetāte pretiōsi!»

Congriō tandem in triclinium intrat duo maxıma fercŭla portāns: in altěrō erat conger oliuis decorātus, in altěrō pauō fartus. Domǐnus irātus Congriōnem uitupěrat: «Sceleste, homō es tardus!» Domǐna autem congrum gustat et exclāmat: «Hic conger est bonus!» Auia pauōnem gustat et exclāmat: «Hic pauō est optřmus». Tunc auus: "Congriō,» inquit, "coquus est arte praestantissimmus.» Congriō hoc audit et rubēscit.

Nunc omnēs rident et loquuntur, dum cibum absūmunt. Marcus Antōnius Fēlix circumspǐcit et, omnēs laetōs uidēns, est quidem fēlix. 


\section{VOCABULÁRIO}

absumĕre: comer; devorar

ac (antes de consoante): $v d$. atque

aduenire: chegar

aedēs, is: $v d . p .114,3$

aestas, ātis: verão

aestate: no verão

alter... alter...: um... outro (vd.p. 67)

amāre: amar

amābō: por favor

amoenus, a, um: agradável

amplecti (só forma passiva): abraçar

animaduertěre: reconhecer

appōněre: servir (uma refeição)

apportāre: trazer

Arpinum, i: Arpino

locativo Arpini: em Arpino

ars, artis: arte

arte praestantissimus: um excelente profissional

atque (antes de vogal); e sobretudo; e ainda

biběre: beber

cadus, i: jarro

Caesar, ăris: César

carmen, innis: poesia

catēna, ae: corrente

Catullus, i: Catulo

cauēre [+acusat.]: acautelar-se com

imperat. caue: cautela com

charteus, ea, eum: de papiro

cibus, i: comida; refeição

Cicěrō, ōnis: Cícero

circumspicĕre: olhar d̀ volta

conditus, a, um: fundado

ab Vrbe condĭtā: desde a fundação da Cidade (= de Roma) conferre (sē): dirigir-se

conger, ri: congro

coniuratiō, ōnis: conjuração ;

conspiração

cōnspicěre: avistar; ver

conuenire: reunir-se

crēbrō: frequentemente

crēděre: crer; julgar

cum [ + indicativo]: quando

decorātus, a, um: decorado

deinde: em seguida

dexter, ra, rum: direito

dextrā parte: do lado direito

dicěre: dizer

imperat. dic: diz (que)

discumberre: instalar-se ou estar

à mesa

diues, rtis: rico

ducěre: conduzir; levar

dum: enquanto

ēbrius, a, um: embriagado

ecce: eis (que)! aqui está!

edacitas, ātis: apetite devorador

edax, ācis: comilão

eděre: comer

epigramma, ătis: epigrama

epos (indeclinável): epopeia

ergō: portanto

ēsurire: estar com fome

ēuocāre: chamar

exclamāre: exclamar

exspectāre: estar à espera

facile: facilmente

fartus, a, um: recheado

fercŭlum, i: prato; bandeja ; travessa

flecti (só forma passiva): dirigir-se 
frequêns, entis: numeroso senātus frequēns: sessão plenária do Senado

furč̌fer, ěri: velhaco; patife

garrǔlus, a, um: falador; tagarela; linguarudo

gaudium, ii: alegria

gustāre: provar (uma comida)

hauē: olá! bom dia! viva!

hercle: por Hércules! palavra de honra! caramba!

hīc: aqui

hodiē: hoje

huc: para aqui; cá

ingēns, entis: enorme

intěrim: entretanto

intrans, antis: aquele que entra

intrāre [+acusat. ou in-acusat.]: entrar em

inuenire: encontrar

ita: assim

ita est: é verdade!

iubēre: ordenar; mandar

laeuus, a, um: esquerdo

laeuā parte: do lado esquerdo lassus, a, um: cansado

dē uiā lassus: cansado $d a$ viagem

lectus, i: leito

summus ) lectus (os três leitos

medius imus

libentius: com agrado

libentius legere: gostar de ler

Liuius, ii: Livio

loqui (só forma passiva): falar malě (advérbio): mal

At uōbis male sit: malditos sejam (= sejais)!

malus, a, um: mau; maldito mênsis, is: mês

mitis, e: doce; manso

mittěre: enviar; mandar

mōnstrāre: mostrar

muttire: resmungar

nidus, i: ninho; estante ou prate-

leira para livros

nōnnullus, a, um: algum

nunc: agora

nugae, ārum: ninharias; pequenas

composições poéticas

oecus, i: grande sala; salão

oliua, ae: azeitona

opěra, ae: obra

opĕrā [+ genit.]: por causa de

optātus, a, um: desejado

ōratiō, ōnis: linguagem; discurso

ōratiō prōsa: prosa

pariēs, ětis: parede

pars, partis: parte; lado

parumper: durante algum tempo

pauō, ōnis: pavão

penděre: estar dependurado; pender

pergamēnus, a, um: de pergaminho

peropportūnē: muito a propósito; mesmo a matar

pictus, a, um: pintado

piger, ra, rum: preguiçoso

placenta, ae: bolo

Plautus, i: Plauto.

plēnus, a, um: cheio

pōcŭlum, i: copo

pōcŭlum tangĕre: tocar nos

copos; embebedar-se

Pompeii, ōrum: vd. p. 47

portans, antis: que traz; trazendo

pōsca, ae: mistura de água com

vinagre; zurrapa 
posse: poder

potest: (ele) pode

praestans, antis: excelente

arte praestantissimus: um excelente profissional

pretiōsus, a, um: precioso

uinum in aetāte pretiōsum:

vinho velho de marca

primō: primeiramente; primeiro prō [+ ablat.]: em vez de

proficisci (só forma passiva) : par-

tir ; dirigir-se

pulsāre [+ acusat.]: bater (a)

quadrātus, a um: quadrado

quadrāta littěra: letria maiúscula

quamquam: embora

quidem: de facto; realmente

quiēscěre: descansar

quis ou qui, quae ou qua, quid ou quod: algum; alguém

quod: porque

rubēscěre: corar (de vergonha ou modéstia)

rus, ruris: (neutro) campo

acusat. rus: para o campo

saeuus, a, um: feroz; bravo

Salustius, ii: Salústio

salutāre: cumprimentar

scelestus, a, um: malvado

scriptus, a, um: escrito

sedēns, entis: que está sentado

sedēre: sentar-se

sērō: tarde

sicut: tal como

singŭli, ae, a: cada um sinister, ra, rum: esquerdo ad sinistram: à esquerda

sitire: estar com sede

solēre: costumar

ut solet: como é seu costume;

como de costume

soror, ōris: irmã

statim: imediatamente; logo

stertěre: ressonar

super: por cima

surgĕre: levantar-se

tandem: por fim

aduēnisti tandem: até que enfim que chegaste!

tangĕre: tocar

tardus, a, um: indolente

tardus homo: molengão

Terentius, ii: Terêncio

titǔlus, i: título

Titus, i: Tito

tunc: então

ubi primum: assim que; logo que;

mal; apenas

uel: ou

uelle: querer

uult: (ele) quer

uenire: vir

Vergilius, ii: Virgílio

uestibŭlum, i: vestíbulo

uestire: vestir; revestir; cobrir

uicinus, i: vizinho

uidēns, entis: que vê; vendo

uinctus, a, um: amarrado; preso

uituperāre: censurar; ralhar com

uolūmen, Ǐnis: volume 
Verta para latim:

\section{I - Acerca da casa de Marco António}

A casa de Marco António, na cidade de Roma, era grande e bela. Na verdade, nela (= naquela: is, ea, id) havia um amplo átrio, um tablino com muitos livros colocados em estantes, e um triclínio, onde se viam (= eram vistos) três leitos e magníficas pinturas. No meio do átrio estava uma artística mesa, junto a um tanque chamado implúvio; por cima deste encontrava-se (= estava) o complúvio. Para o implúvio corriam as águas da chuva através de gárgulas. No centro do peristilo havia um pequeno jardim. Aí Cláudia, mulher de Marco António, com o jardineiro Hortênsio, cultivava rosas, violetas, narcisos e outras flores. Brancas pombas voavam por toda a parte e iam pousar (= pousavam) nas estátuas dos deuses que decoravam o jardim.

No verão, Marco António habitava, com a família, (n)uma casa (de campo) não longe da cidade de Roma, porque não apenas esta cidade era muito quente, mas também (porque) Marco António gostava da vida do campo.

\section{VOCABULÁRIO}

amplo: amplus, a, um

aí: $i b i$

artística: artificiōsus, $a$, um

branco: albus, a, um

chamado: nuncupātus, a, um

chuva: pluuia, ae

colocado: positus, a, um

correr (um líquido): fluere

cultivar: colère

decorar: örnāre

estátua: statua, ae

flor: flōs, flōris (masc.)

gárgula: fistŭla, ae

livro: uolümen, inis

longe (não... de): nōn longē $a(b)$

(+ abl.)

magnífico: magnificus, $a, u m$ mesa (de átrio): cartibǔlum, $i$

muito: multus, a, um

mulher: uxor, öris

narciso: narcissus, $i$

parte (por toda a...): undique

pequeno: paruus, $a$, un

pomba: columba, ae

pousar: considerre $(+$ in + abl. $)$

quente (ser muito...): calēre

tanque: stagnum, $i$

três: trēs (masc. e fem.), tria

(neutro)

verão: aestas, ātis

no verão: aestāte

violeta: uiōla, ae

voar: uolāre 
II - Sobre os filhos (isto é, o filho e a filha) de Marco António

$\mathrm{O}$ banqueiro Marco António era um homem muito rico: por isso tinha ainda uma outra (N.B.: outra de três: vd. p. 67) casa situada no litoral, perto de Óstia. A Gaio Púlquer e a Antónia, filhos de Marco, agradava mais viver no litoral do que na cidade. Mas seu pai (= o pai daqueles: $i s, e a, i d$ ) tinha o banco no foro de Roma (= no foro romano) e o mar estava bastante longe da Cidade. Por esse motivo, raramente lhes (= àqueles) era possível correr na areia da praia ou nadar nas ondas salgadas. Além disso, era preciso estudar e só na cidade havia grandes escolas e bons mestres. Contudo, quando o pai tinha vagar e o tempo estava bom, recuperavam os dias perdidos.

\section{VOCABULÁRIO}

agradar: placēre

ainda: etiam

além disso: praeter

areia: harēna, ae

a. da praia: ha. mariť̌ma

banco: argentaria, ae

banqueiro: argentarius, ii

bastante longe de: satis longē $a(b)$

[+ abl.]

contudo: autem (em 2.0 lugar da frase)

correr: currère

do que: quam

então: tunc

estudar: studēre

litoral: ōra(ae) maritüma(ae)

mais: magis

mar: mare, ris (neutro)

mestre: magister, $r i$

nadar: natāre

onda: unda, ae
Óstia (porto na foz do Tibre): Ostia, ae perdido: amissus, a, um

possível (ser...): licēere $(+$ dat. + + infinit.)

preciso (ser...): opus esse (+ infinit.)

que (do...): quam

quando: cum

raramente: rarō

recuperar: recuperāre

rico (muito...): ditissĭmus, a, um

salgado: salsus, $a$, um

situado. posǐtus, a, um

só (= somente): tantum

tempo (atmosférico): tempestas, ātis (fem.)

vagar (ter...): uacāre

viver (= passar a vida): uitam dēgěre 


\section{III - A respeito dos criados de Marco António}

Marco António tinha (vd. pp. 77-78) três criados e uma criada: Vínio, Congrião, Hortênsio e Servília. Contudo, o patrão não andava (= estava) contente. É que Vínio gostava de beber; Congrião, apesar de excelente cozinheiro, era comilão; Hortênsio (era) molengão; Servília (era) linguareira. Até o cão, embora se chamasse (= chamado) Cérbero, era manso e não guardava a casa.

Quando Marco António entrava em casa, Cérbero estava sempre a dormir (= dormia sempre), estiraçado no vestíbulo, onde se lia (= era lido) «Cautela com o cão»; Servília ou cantava ou dava à língua com os outros criados; Vínio ressonava na adega, bêbado como um cacho; na cozinha, Congrião estava a ser (=era) repreendido por Cláudia: «Maldito,» vociferava a mulher, «onde está o congro para o almoço?»; no jardim, as flores murchavam: é que Hortênsio, sempre cansado, não as regava diariamente. "Oh, que desgraça a minha!», resmungava Marco António, enquanto se dirigia para o tablino.

\section{VOCABULÁRIO}

adega: cella(ae) uinaria(ae)

almoço: prandium, ii

apesar de: quamquam

atê: etiam

bêbado: èbrius, $a$, um

b. como um cacho: plēnus uini

cansado: lassus, a, um

chamado: uocātus, a, um

comilão: edax, ācis

congro: conger, $r i$

contente: laetus, a, um

dar à língua: garrire

desgraça: miseria, ae

$\mathrm{Oh}$, que desgraça a minha!:

Vae misěrō mihi!

diariamente: quotidie

dirigir-se para: tenděre ad ( + ac.)

dormir: dormire

embora: quamquam enquanto: dum

estiraçado: porrectus, a, um

excelente: optimus, $a$, um

guardar: custōdire

linguareiro: garrülus, a, um

maldito: scelestus, $a$, um

manso: mitis (masc. e fem.) mite (n.)

molengão: tardus, $a$, um

murchar: marcēscère

ou... ou: uel... uel...

patrão: dominus, $i$

regar: rigāre

resmungar: muttire

repreender: obiurgāre

ressonar: stertẽre

sempre: semper

um (numeral): unus, $a$, um

vociferar: clamitāre 


\section{THERMAE}

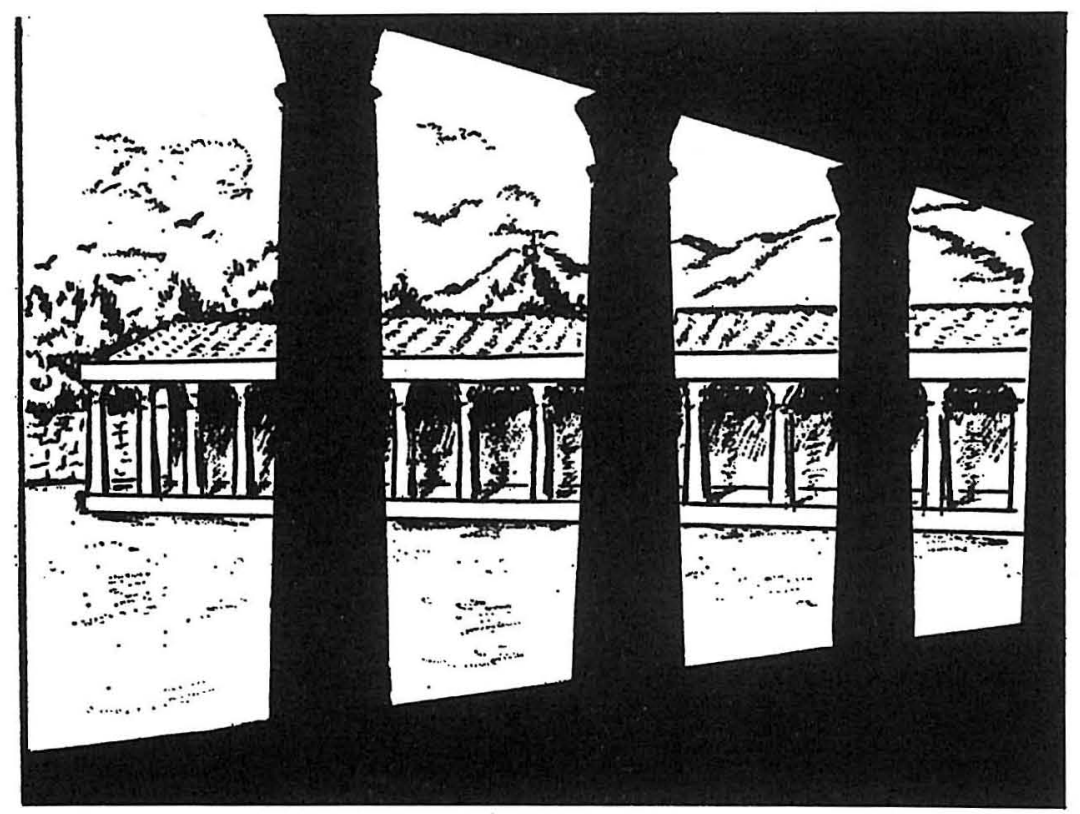

POMPEIOs: Palaestra

\section{I - In palæstră}

Ante cēnam M. Antōnius Fēlix thermas frequentābat, quod nōn sōlum corpus exercēre amābat, sed etiam ibi amīcōs inueniēbat cum quibus garriēbat. Cum ad thermas adueniēbat, ōstiariō pecuniam dabat; deinde thermas intrābat. In porť̌cu paulisper siděre solēbat, dum athlētas spectābat et seruus ei uinum offerēbat.

Palaestra frequentissimma semper erat: ibi enim uiri uel saliēbant uel currēbant uel discōs ac têla ēmittēbant uel pugnābant uel in amplā piscīnā natābant; in dēstrictariō serui oleō et strigilǐbus dominōrum corpǒra dēstringēbant.

Hodiē autem Antōnius erat fessus, quia ab ortō sōle ad meridiem in forō labōrauěrat: «Nimia est miseria nimis diư̌tem mē esse! Omnēs hominēs mutuas pecunias a mē petunt: mē ōrant, ambiunt, exobsěcrant. Nē illi molesti sunt! Meō negōtiō nōn licet mẽ opěram dare. $\overline{\mathrm{O}} \mathrm{mē}$ infēlicem!» Fēlix mussitābat, dum apodytērium intrābat. 


\section{II - In apodytêrio}

Postquam apodytērium intrāuit, Antōnius Fēlix se exuit. Ei in anĭmō erat paulisper siděre, quia ibi nunquam erant multi homǐnēs. Nam uiri garrientēs, poētae recitantēs, cantōrēs cantantēs et ōratōrēs ōratiōnēs habentēs in caldariō semper erant. Dum sē exuēbat, Antōnius: «Mehercle», inquiēbat, «nē ego fessus sum! Argentaria mē confícit». Subð̌tō magnus tumultus fit: «Fur! Fur! Fur!» conclāmant serui uirum, qui togas in apodytēriō surripiēbat, tenentēs; $\overline{\mathrm{e}}$ frigidarii alueō ac tepidarii uapōre uiri nudi concurrunt: «Furç̌fer! Sceleste! Verběrō!» alii et alii uōciferantur; omnia tumultu miscentur. Marcus Fēlix autem in angŭlō stans ingemiscit: «Hei mihi! Apud mē serui sunt pessimmi; in forō omnēs homǐnēs odiōsi; hic tantum furēs ac garrŭli. Vbǐnam gentium mihi erit alǐquid tranquillitātis?!»

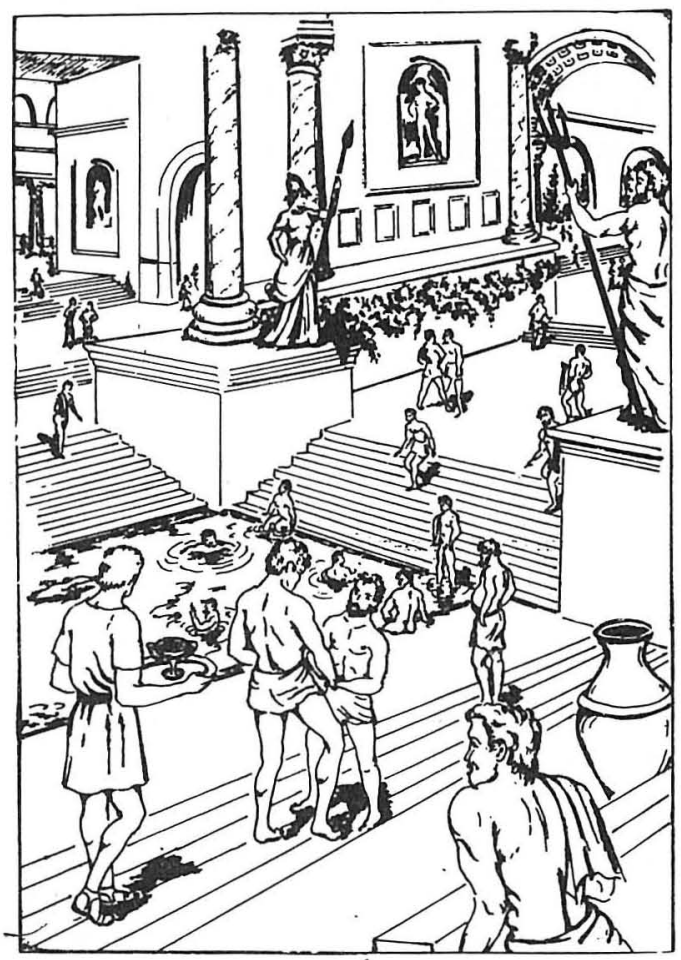

FRIGIDARIVM 


\section{VOCABULÁRIO}

aduenire: chegar

alueus, $i$ : tina, banheira

ambire: fazer rodeios; assediar

angülus, $i$ : canto (de sala)

animus, $i$ : espírito; intenção

in animō esse ( + dat. + inf.):

ter a intenção de

ante $(+\mathrm{ac}$.$) : antes de$

apodytērium, ii: vestiário

caldarium, ii: caldário (sala de

banhos quentes)

cēna, ae: jantar (refeição)

conclamāre: gritar à uma

concurrère: acorrer

conficère: matar; dar cabo de

currère: correr

dare: dar

operram dare: prestar atenção

deinde: em seguida

dêstrictarium, ii: destrictário (local

dos balneários destinado à lim-

peza da pele)

dēstringère: limpar (raspando)

discus, $i$ : disco

diues, ¿̌tis: rico

dum: enquanto

èmittěre: lançar

exercēere: exercitar

exobsecrāre: suplicar

exuěre: despir

pret. perf. do ind. exui

fessus, a, um: cansado

fiëri: fazer-se (= ser feito)

magnus tumultus fit: arma-se grande confusão frequēns, tis: frequentado

frequentissimus, $a$, um: que está à cunha

frigidarium, ii: frigidário (sala de banhos frios)

fur, furis: ladrão

garrire: palrar; cavaquear

garriēns, entis: aquele que tagarela; a tagarelar

hei! (interj.): ai!

hei mihi!: ai de mim!

hic (advérbio; não confundir com

hic 'este'): aqui

infēlix, icis: infeliz

$\bar{o}$ mē infélicem! (acusat. exclamativo): oh, que infeliz eu sou!

ingemiscěre: gemer; lamentar-se inuenire: encontrar

labōrauërat: pret. m.-q.-p.

do ind. de labōrāre 'trabalhar'

licet (verbo impessoal): é permitido

mehercle! (interj.): por Hércules! caramba!

miscēre: misturar

omnia tumultu miscentur: a confusão é geral

miseria, ae: desgraça

molestus, a, um: importuno; chato mussitāre: dizer entre dentes

$n \bar{e}$ : certamente

$N \bar{e}$ ego...!: Mas quẹ... eu...!

$N \bar{e}$ illi...!: Mas que... eles...!

nimis: excessivamente

nimis diues: assim tão rico 


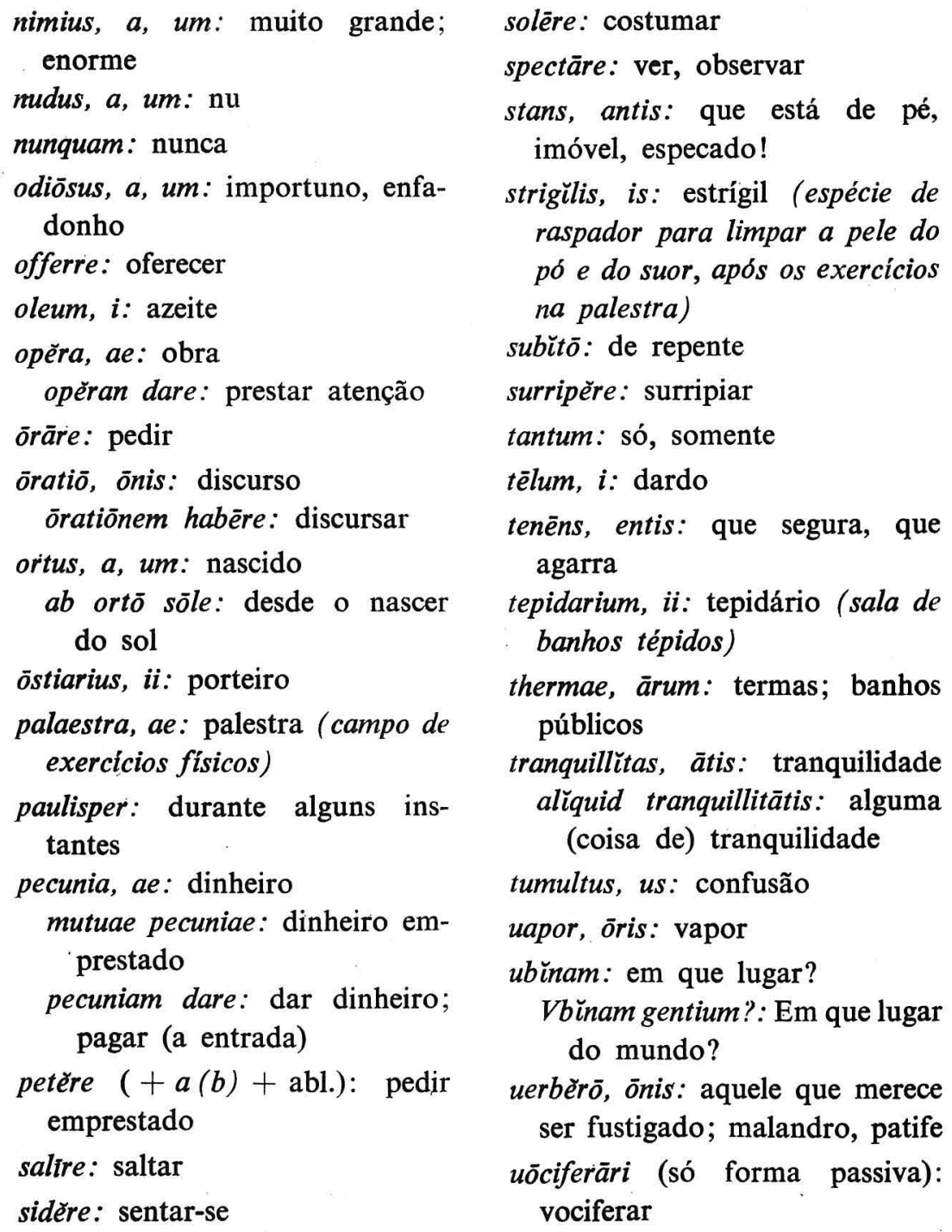


Na cidade de Roma havia muitas termas. À tarde, os Romanos costumavam frequentá-las, porque aí não apenas lhes era possível praticar desporto na palestra, como ainda cavaquear com os amigos e informar-se da política. No caldário, banhavam-se em água quente; no frigidário, em água fria. $\mathrm{Na}$ banheira do caldário havia sempre muita gente, principalmente no inverno; no verão, porém, os Romanos preferiam nadar na ampla piscina da palestra.

Nas termas havia muitos escravos: uns guardavam o apoditério, outros trabalhavam no destrictário e na palestra, outros tomavam conta do aquecimento, outros desempenhavam outras funçб̃es.

As termas não eram um lugar sossegado. Na verdade, até por vezes eram apanhados ladróes que surripiavam (= surripiando) as togas no apoditério. Quando tal acontecia, então a confusão era geral.

\section{VOCABULÁRIO}

acontecer: acciderre

aquecimento: praefurnium, ii apanhar: capere

até: etiam

banhar-se: v. pass. de lauäre

desempenhar outras funçб̃es: alia curāre

desporto (praticar...): sē exercēre então: tum

frio: frigìdus, $a$, um

gente: pl. de homō, innis

guardar: custōdire

informar-se (= ser informado): certiōrem fièri ( + dēe-ablativo)

inverno: hiems, hiěmis

No inverno: hiěme

lugar: locus, $i$

política: rēspublica, reipublǐcae possível $($ ser...): licēre $[+$ dat. + + infinit.]

preferir: malle (pret. imp. do ind. malēbam, etc.)

principalmente: imprimis

quente: calidus, $a$, um

sossegado: tranquillus, $a$, um

surripiando (= que surripia): surripians, antis

tal (coisa): tale, is (neutro de talis, e)

tarde: postmeridiānum tempus

à tarde: postmeridiānō tempòre

tomar conta de: uidēre ( + acusativo)

verão: aestas, ätis

no verão: aestāte

vezes (por...): aliquandō

até por vezes: aliquandō etiam 


\section{IN THEATRŌ}

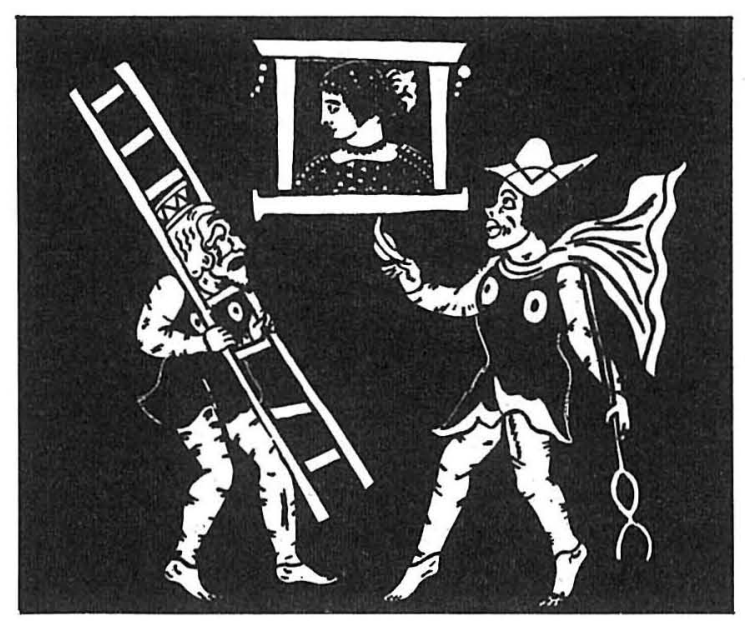

Illā diē theatrum celebritāte refertissĭmum erat. Matūrē enim uiri et muliěrēs et puěri caueam tōtam explēuěrant. Erat in uniuersō consessu maxĭma exspectatiō: nam optŭmus grex acturus erat Plauti comoediam Amphitryōnem.

Marcus Antōnius Fēlix cum uxōre et libĕris et Luciō in mediā spectatōrum turbā sedēbat et, dum initium fabǔlae exspectābant, carǐcas et nucēs edēbant. Interea uiri dē rēpublǐcā loquēbantur, muliěrēs garriēbant et puěri somni plēni flēbant.

In huiusmǒdi trepidatiōne rērum, comoedus Mercurii agēns partēs in scēnam prōdit et prolŏgum dēclāmat. Consessus autem studiōsē nōn audit captatiōnem beneuolentiae. Quā dē causā Mercurius argumentum comoediae magnā uōce ēloqưtur:

«Haec urbs est Thēbae; in illisce hab̌rtat aedřbus

Amphitryō, natus Argis ex Argō patre, quicum Alcumēna est nupta, Ēlectri filia...»

Nunc spectatōrēs iam anĭmō adsunt: nam opĕrae pretium erit Iouem et Mercurium histriōniam facĕre.

Fabŭla inç̌pit: primā luce Sōsia, Amphitryōnis seruus, portans lucernam domĭni aedēs petit. Ecce uidet... altěrum Sōsiam in limǐne stantem! Ridet omnis consessus: nam Mercurius sibi sumpsĕrat Sōsiae imağnem, sicut Iupp̆̌ter sē uertěrat in Amphitryōnis imağnem. 


\section{VOCABULÁRIO}

actūrus, a, um: que vai representar actūrus eram: eu ia representar adesse: estar presente

anĭmō adesse: prestar atenção agēns, entis: que desempenha um papel (numa peça de teatro) Alcumēna $=$ Alcmēna, ae: $A l c-$ mena

Amphitryō, ōnis: Anfitrião

Argi, ōrum: Argos

Argus, a, um: argivo (= natural de Argos)

captatiō, ōnis: captação

captatiō beneuolentiae: aç̧ão de captar a benevolência; pedido de benevolência

carǐca, ae: figo seco

cauea, ae: parte do teatro reservada aos espectadores; bancada celebrĭtas, ātis: grande multidão; afluência

comoedus, i: actor (de comédia) consessus, us: multidão sentada; assistência

$a b l$. sing. consessu

Ëlectrus, i: Electro

ēlŏqui (só forma passiva): expor explëre: encher completamente pret. m.-q.-perf. ind.: explēuěram

exspectāre: aguardar

exspectatiō, ōnis: expectativa

fabŭla, ae: peça de teatro; enredo flēre: chorar

garrire: palrar; tagarelar

grex, gregis: rebanho; companhia (de teatro) histriōnia, ae: profissão de actor histriōniam facĕre: desempenhar um papel; fazer comédia huiusmŏdi: deste modo

illisce (ablat. pl. arcaico) = illis, de ille, illa, illud

imāgō, Ĭnis: imagem; aparência incipĕre: começar

interea: entretanto

limen, İnis: limiar ; soleira da porta loqui (só forma passiva): falar dē rēpublīca loqui: falar de ou discutir politica

lucerna, ae: candeia

lux, lucis: luz

primā luce: ao romper do dia matūrē: muito antes da hora natus, a, um: nascido

Argis natus: nascido em Argos; natural de Argos

nuběre: casar (N.B.: este verbo tem sempre por sujeito a mulher)

est nupta: (ela) está casada nux, nucis: noz opĕra, ae: trabalho opĕrae pretium est: vale a pena (observar)

pars, partis: parte; no pl. papel (de um actor)

petĕre [+ acusat.]: dirigir-se para plēnus, a, um: cheio portans, antis: que transporta lucernam portans: com uma candeia na mão

prōdire: aparecer; in scēnam prödire: aparecer em cena 
puer, puĕri: menino; criança quicum (ablat. arcaico) $=$ cum quō: com o qual

refertus, a um: cheio; atulhado theatrum celebritāte refertisšrmum: teatro à cunha scēna, ae: cena; palco Sōsia, ae: Sósia spectātor, ōris: espectador stans, antis: que está especado studiōsē: atentamente; studiōsē audire: escutar com atenção sumĕre: tomar; assumir pret. m.-q.-perf. ind.: sumpsěram sibi suměre imaginem: tomar $a$ aparência (de)

Thēbae, ārum: Tebas

trepidatiō, ōnis: desordem

in huiusmŏdi trepidatiōne rērum: no meio de uma tal confusão

uertěre: voltar

pret. m.-q.-perf. ind.: uertěram sē uertěre in imagǐnem alicuius: transformar-se na figura de alguém

uniuersus, a, um: todo inteiro uōx, uōcis: voz

magnā uōce: com voz forte

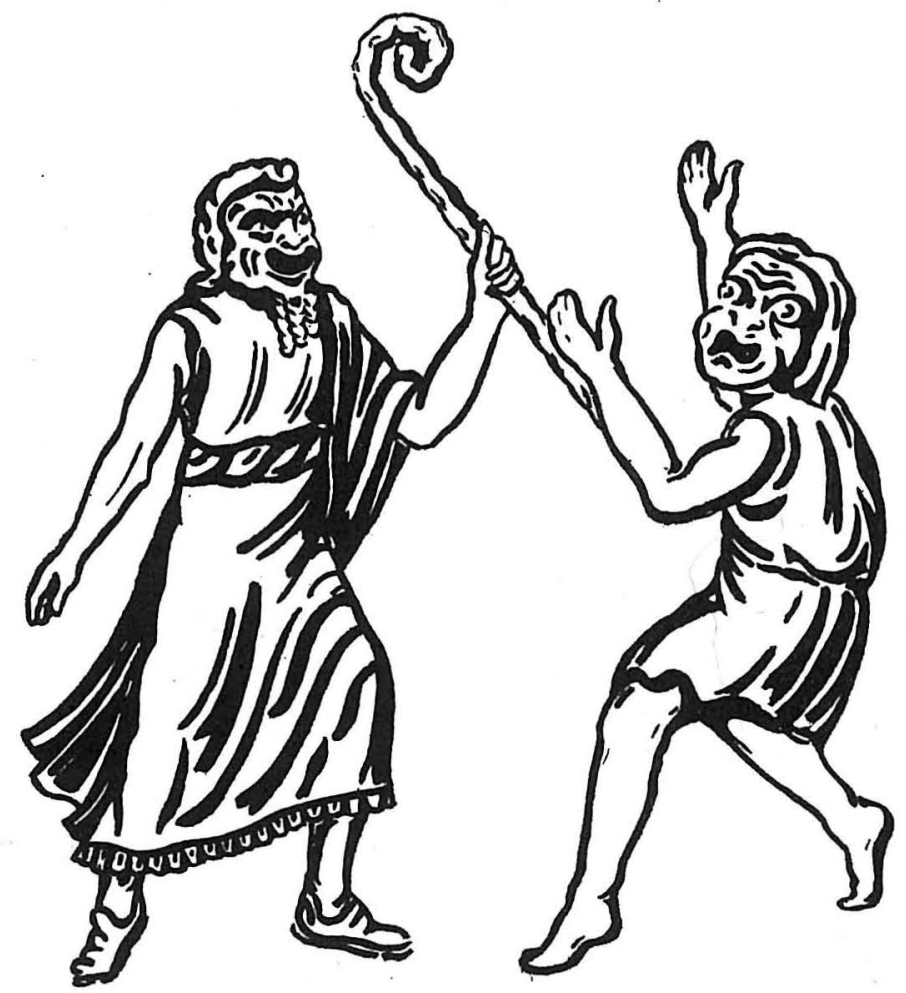

Scelědrus seruus a Periplectomènō sene tapŭlat. 
Verta para latim:

\section{António e Lúcio representam uma comédia de Plauto}

Chovia há (= durante) já alguns dias em Roma. Por esse motivo António e Lúcio não podiam brincar no jardim, como costumavam. Retidos em casa, os rapazes resolvem representar, no tablino, uma comédia de Plauto. Após longa discussão, escolhem a peça do soldado fanfarrão. «Eu [cá] vou ser (= serei) o velho Periplectómeno,» diz António; «tu, Lúcio, desempenhas (= desempenharás) o papel do escravo Céledro.»

Rindo às gargalhadas, os rapazes estavam a representar (= representavam) os [seus] papéis, quando os pais de António entram no tablino. Então Lúcio, como um autêntico actor de comédia no fim da peça, exclama: - Agora, espectadores, batam (= batei) palmas.

\section{VOCABULLÁRIO}

agora: nunc

alguns: aliquot (indeclinável)

após: post [+ acusat.]

autêntico: germānus, $a$, um

bater palmas: plaudère

imperat. plaude, plaudite

brincar: ludère

casa: domus, us

em casa: domi (locativo)

Céledro: Scelědrus, $i$

chover: pluěre

como: $u t$

costumar: solēre

desempenhar o papel: sustinēre partēs

discussão: disceptatiō, ōnis

durante: per [+ acusat.]

escolher: dēligerre

fanfarrão: glōriōsus, $a$, um fim: finis, is

gargalhada: cachinnus, $i$

que riem às gargalhadas:

cachinnōs tollentēs

já: iam

jardim: hortus, $i$

longo: longus, a, um

pais (= pai e mãe): parentēs, um peça (de teatro): fabũla, ae

Periplectómeno: Periplectomènus, $i$ poder: posse

pret. imperf. ind. potěram

representar: agère

resolver: statuerie

retido: retentus, $a$, um

Roma: Röma, ae

em Roma: Rōmae (locativo)

soldado: miles, ǐtis

velho: senex, senis 
N.B. :

Os adjectivos da $2 .^{a}$ classe são todos de tema em -i-

\section{I - UNIFORMES :}

$\begin{array}{lll}\text { Masculino } & \text { Feminino } & \text { Neutro } \\ \text { prudēns } & \text { prudēns } & \text { prudēns }\end{array}$

\section{Singular}

$\begin{array}{lll}\text { N. } & \text { prudēns } \\ \text { V. } & \text { prudēns } \\ \text { Ac. } & \text { prudentem } & \\ \text { G. } & \text { prudentis } \\ \text { D. } & \text { prudenti }\end{array}$
Ab. prudenti
prudenti

ou

prudente

\section{Plural}

\begin{tabular}{|c|c|c|}
\hline N. & prudentēs & prudentiă \\
\hline V. & prudentēs & prudentiă \\
\hline Ac. & prudentēs & prudentiă \\
\hline 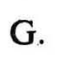 & & prudentium \\
\hline & & prudentǐbus \\
\hline b & & prudentǐbus \\
\hline
\end{tabular}


II - BIFORMES :

Masculino

fortis

Singular

N. fortis

V. fortis

Ac. fortem

G.

D.

Ab.

Plural

N. fortēs

V. fortēs

Ac. fortēs

G.

D.

Ab.

\section{III - TRIFORMES :}

Feminino

fortis

Neutro

forte forte

forte

forte

fortis

forti

forti fortiă

fortiă

fortiă fortium

fortybus

fortybus
Feminino

acris
Neutro

acre

\section{Singular}

N. acer

V. acer

Ac. acrem

G.

D.

Ab.

acris

acre

acris

acre

acrem

acre

acris

acri

acri 
Plural

$\begin{array}{llll}\text { N. } & \text { acrēs } & & \text { acriă } \\ \text { V. } & \text { acrēs } & & \text { acriă } \\ \text { Ac. } & \text { acrēs } & & \text { acriă } \\ \text { G. } & & \text { acrium } & \\ \text { D. } & & \text { acrǐbus } & \\ \text { Ab. } & & \text { acrǐbus } & \end{array}$

EXERCICIOS :

I - Decline :

amăns, amantis aquele, aquela, aquilo que ama grandis, grande grande celer, celěris, celĕre rápido

II - Decline :

homō sapiēns homem sábio gēns nōbīlis familia nobre respōnsum celĕre resposta pronta

N. homō sapiēns

V.

Ac.

G. homĭnis

D.

Ab. 
N. gēns nōbīlis

V.

Ac.

G. gentis

D.

Ab.

N. respōnsum celĕre

V.

Ac.

G.

D.

Ab.

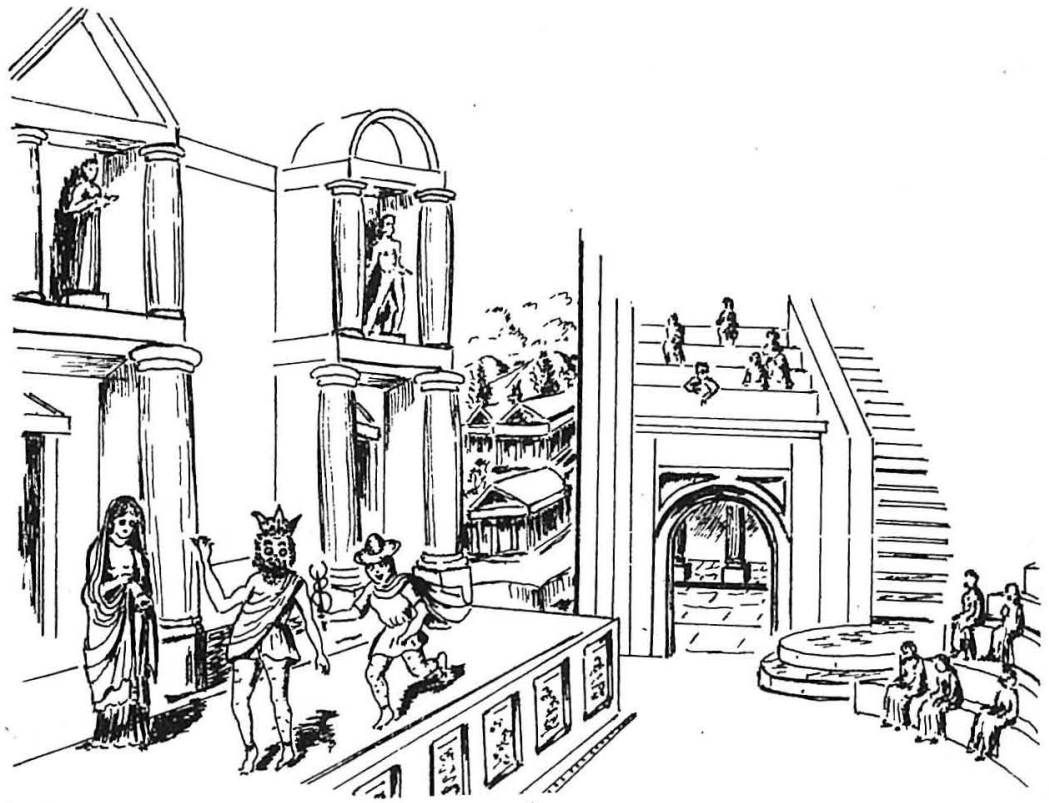




\section{Dê mulierřbus a Ioue amãtis}

\section{Dē Eurōpae raptu ${ }^{1}$}

Iuppriter uxōrem habēbat Iunōnem. Deus autem aliquandō uidet pulcherrĭmam Eurōpam, Agēnǒris rēgis Phoenīcae filiam, et amōre captus cōnsilium eam rapěre capit. Aliquandō, cum Eurōpa cum aliis puellis in pratō ludēbat, Iuppĭter in figüram mitis tauri conuersus in cōnspectum eārum uenit. Omnēs uirginēs pauentēs fugam capiunt; Eurōpa sōla nihil metuēns ad taurum appropinquat et serta in cornǐbus 2 intēxit. Taurus genua 2 flectit ac lēnǔter mugit, et incauta puella eum inscendit. Tum in mare currit taurus et pedǐbus incitātis super undas aduŏlat. Eurōpa maximam uim lacrimārum profundēns inclāmat, sed taurus, continuātō et die et nocte itiněre, aduěnit in insulam Crētam. Ibi Iuppĭter fōrmam diuinam resūmēns Eurōpam sibi coniungit, quae interposîtō tempore filiōs duōs, Minōem et Rhadamanthum, gignit.

1 Vd. p. 151.

2 Vd. p. 152.

\section{Dē Alcmēnā, Hercŭlis matre}

(Vd. p. 136)

Ōlim erat in Boeōtiā urbs, nōmǐne Thēbae. Ibi uitam agēbat Amphitryō, Argis natus, qui uxōrem habēbat Alcmēnam, Ēlectri filiam. Iuppĭter autem, Alcmēnae amōre captus, sē uertit in Amphitryōnis imaginem et clam maritum eam occĭpit amāre. Sic pudica Alcmēna, Iouis dolum ignōrans, utrimque graữda fuit, et ex uirō et ex Ioue. Bellō Telebois a Thēbānis indictō 1 , Amphitryō praefectus legiōnǐbus in exercìtum abit. Dum prō patriā cum hostǐbus dēcernit, Iuppitter, in faciem eius uersus, hab̆tat cum Alcmēnā. Omnēs qui apud Amphitryōnem uidēbant Iouem, Alcmēnae maritum esse cēnșēbant: ita summus deus uersipellem sē faciēbat quotiēscumque libēbat! Vbi primum uērus Amphitryō ab exerč̌tu 2 redit, Alcmēna unō partu 3 filiōs geminōs duōs parit, altěrum ${ }^{4}$ Amphitryōnis, altěrum Iouis. Sed dei filius, cui postea fuit nōmen Hercŭlēs 5, quamuis modo natus, erat magnus ac ualidisšmmus: nam nutrix colligāre eum incunabŭlis nōn quiēbat! Cum puěri in cunis iam erant, duo maxymae anguēs a 
zêloty̆pā Iunōne missae dē tèctō dëuơlant et ad cunas pergunt. Tum puer ille, qui maior atque ualidior erat, citus ē cunis exš̌lit, facit rēctã in anguēs impětum et pernič̌ter eas prehendēns altěram altěrā manu 6 ēněcat. Hoc fuit primum Herculis fačnus.

1 Bellö ... indictō «declarada a guerra...»: esta expressão, constituída por subst. + participio, ambos em ablativo, tem um valor temporal-causal (ABLATrvo ABSOLUTO OU ORACIONAL).

2 ab exerč̀tu «da tropa; da guerra»: Vd. p. 151.

3 unó partu «de um só parto»: Vd. p. 151.

4 altěrum ... altěrum «un ... o outro»: Vd. p. 67.

5 Vd. p. $78, N . B$.

6 altèram altěrā manu «uma em cada mão»: Vd., supra, nota 4.

\section{Dē loue, in fōrmam cycni mutātō, et Lèdā}

Inter plurimmas muliěrēs ab Ioue amātas erat Lēda, rēgis cuiusdam Aetōlōrum ${ }^{1}$ filia ac Tyndarěi uxor.

Aliquandō Lēda, cum in flumǐne Eurōtā lauabātur, uidet pulchrum ac candǐdum cycnum, qui ad eam adnătans alis complexus est. Breui post Lēda duo ouna gignit: ex altěrō 2 nati sunt Castor et Pollux, ex altěrō Helěna et Clytaemnestra.

Castor et Pollux, Dioscūri uel Tyndarĭdae quoque uocāti, germāni Iouis filii erant: quarē immortalĭtas eis dōnāta est. Amici fidisš̌mi nōn sōlum rēs maxĭmas gerunt, sed quoque praeš̃dēs sunt nautārum hospitumque 3. Dioscūri postea mutāti sunt in Gemǐnōs quōs etiam nunc in caelō uidēmus.

Helěna et Clytaemnestra autem aliis dē causis praeclarissimae sunt: nam Helěna, Menelāō Lacedaemōniōrum rēgi nupta atque a Trōiānō Parĭde abducta, fuit belli Trōiāni causa; Clytaemnestra, uxor Agamemnonis Mycenārum rēgis fratrisque Menelāi, marîtum Trōiā ${ }^{4}$ aduenientem, adultěrō Aegisthō adiutōre 5, trucidāuit.

1 rēgis cuiusdam Aetōlörum «de um rei da Etólia»: Vd. p. 84.

2 Vd. nota 4 do texto anterior.

3 Vd. p. 84.

4 «de Tróia»: compl. circ. de lugar donde: note que os nomes de cidade não levam preposição.

5 adultèrō ...... adiutōre "com a ajuda de Egisto, seu amante»: vd. nota 1 do texto anterior. 


\section{VOCABULÁRIO}

abductus, a, um: raptado

abire: ir-se embora; partir

in exercitum abire: partir para

a guerra

adnatāre: nadar (em direç̧ão a) adueniēns, entis: que chega; ao chegar

aduenire: chegar

adulter, ěri: amante

aduolāre: precipitar-se (para)

Aegisthus, i: Egisto

Aetōli, ōrum: Etolos

Agamemnōn, ŏnis: Agamémnon

Agēnōr, ŏris: Agenor

agěre: conduzir; levar

uitam agere: viver

ala, ae: asa

autem: porém

Alcmēna, ae: Alcmena

amātus, a, um: artado

Amphitryō, ōnis: Anfitrião

anguis, is: serpente

Argi, ōrum: Argos

Argis natus: nascido em Argos;

natural de Argos

Boeōtia, ae: Beócia

breui: brevemente

breui post: pouco tempo depois

candìdus, a, um: branco (brilhante)

captus, a, um: seduzido

amōre captus: perdido de amores

Castor, ŏris: Castor

causa, ae: causa; motivo

aliis dẽ causis: por motivos bem diversos censēre: pensar; cuidar

marītum esse censēre: cuidar que se tratava do marido (= que era o marido)

citus, a, um: ágil; ligeiro clam [+ acusat.]: às escondidas de Clytaemnestra, ae: Clitemnestra colligāre: atar; apertar complexus, a, um: abraçado complexus est: ele abraçou coniungĕre: unir

alĭquam sibi coniungěre: unir-se a alguma mulher cōnsilium, ii: decisão cōnspectus, us: aspecto; presença in cōnspectum alicuius uenire: ir ter com alguém continuātus, a, um: contínuo conuersus, a, um: transformado cunae, ārum: berço cycnus, i: cisne dēcernĕre: combater; bater-se dēuolāre: lançar-se em voo Dioscūri, ōrum: Dioscuros ( $=f i-$ lhos de Zeus/Júpiter) dolum, i: ardil dōnāre: dar de presente dōnāta est: foi concedida Ëlectrus, i: Electro ēnecāre: matar; estrangular etiam: ainda

Eurōtas, ae: Eurotas exsilire: saltar (para fora) fač̌nus, ŏris: façanha fidissimus, a, um: muito fiel; inseparável

flectěre: dobrar 
förma, ae: forma; molde in förmam mutatus [+ genit.]: metamorfoseado em

fuga, ae: fuga

fugam capěre: pôr-se em fuga

Gemini, ōrum: Gémeos (constelação do Zodíaco)

gerěre: realizar

rēs maxĭmas gerĕre: cometer as maiores façanhas

germānus, a, um: que é da mesma raça; verdadeiro

gignĕre: gerar; dar à luz

Helěna, ae: Helena

Hercŭlēs, is: Hércules

hospes, ittis: hospedeiro; hóspede praesĩdēs hosprtum: deuses tute-

lares da hospitalidade

hostēs, ium: inimigos

imāgō, ĭnis: figura

immortalĭtas, ātis: imortalidade

impětus, us: ataque

impětum facěre in alĭquem: arremeter contra alguém

incitātus, a, um: rápido; acelerado pedřbus incitātis: a todo o galope

inclamāre: pedir socorro

incunabŭla, ōrum: fraldas alĭquem incunabŭlis colligāre: apertar as fraldas a alguém indicĕre: declarar

bellum alicui indicěre: declarar guerra a alguém

inscenděre [ + -acusat.]: subir ; montar em

interposǐtus, a, um: intercalado interposítō tempǒre: algum tempo depois intexĕre: entrelaçar

ita: $t a l$

ita uersipellem sē faciēbat: de tal modo ele era hábil em mudar de pele

iter, itiněris (neutro): caminho continuātō itiněre: (correndo) sem parar

Lacedaemōnii, ōrum: Lacedemónios (= Espartanos)

lauāre: lavar; na pass. banhar-se Lēda, ae: Leda

lēnirter: docemente; com mansidão libēre [ + dat.]: agradar[-lhe]; dar[-lhe] prazer; dar[-lhe] na real gana

maxĭmus, a, um: enorme

Menelāus, āi: Menelau

metuēns, entis: que tem receio

nihil metuēns: sem nada recear; sem qualquer receio

Minōs, ōis: Minos

missus, a, um: enviado

mitis, e: manso

modo: há pouco

modo natus: recém-nascido

mugīe: mugir

mutātus, a, um: transformado mutati sunt: foram transformados (= transformaram-se)

Mycēnae, ārum: Micenas

natus, a, um: nascido

nati sunt: nasceram

nunc: agora

etiam nunc: ainda hoje

nupta, ae [+ dat.]: casada (com)

nutrix, icis: ama (=que amamenta)

occipĕre: começar 
alĭquam occipěre amāre: começar de amores com uma mulher

ouum, i: ovo

parīre: dar à luz

Paris, ídis: Páris

pauēns, entis: espavorido

pergĕre: dirigir-se

pernicǐter: com ligeireza; num

abrir e fechar de olhos

Phoenica, ae: Fenícia

plurimus, a, um: numeroso ; diverso

Pollux, ūcis: Pólux

postea: posteriormente; depois

praeclarissimus, a, um: muito conhecido

praeclarissimae sunt: notabilizaram-se

praefectus, a, um [ + dat.]: (que está) à frente; (que vai) à frente

praeses, Iddis: presidente; patrono praeš̃dēs nautārum: deuses tutelares da navegação

prehendēns, entis: que agarra; agarrando

prō [+ abl.]: por; em defesa de profundēns, entis: que derrama maximam uim lacrimārum profundēns: desfeito em lágrimas pudicus, a, um: casto

quamuis: apesar de

quire: ser capaz (em frases negativas) quoque: também

quotiēscumque: todas as vezes

que; sempre que

rapěre: raptar

rēctā: directamente; a direito

redĩre: regressar

resūmēns, entis: que retoma;

retomando

Rhadamanthus, i: Radamanto

serta, ōrum: grinalda $(s)$

sōlus, a, um: só; sozinho

Eurōpa sōla: Europa é a única que

tēctum, i: tecto; casa

Teleboae, ārum: Teléboas

Thēbae, ārum: Tebas

trucidāre: assassinar

Tyndarĕus, èi: Tíndaro

Tyndarĭdae, ārum: Tindáridas

(=filhos de Tíndaro)

ualidior, ōris: mais forte

ualidissimus, a, um: muito forte uel: ou

uersipellis, e: que muda de pele ou de aparência

uersus, a, um: mudado

in faciem alicuius uersus: metamorfoseado na figura de alguém

uertěre: transformar

uērus, a, um: verdadeiro

uocātus, a, um: chamado

utrimque: duplamente; de um $e$ de outro

zēloty̆pa, ae: ciumenta 


\section{COMPOSTOS DE ESSE}

(Vid. p. 32)

absum, abes, abesse, afui:

estar ausente; distar

adsum, ades, adesse, affui:

estar presente; assistir

dēsum, dees, deesse, dēfui:

faltar

insum, ines, inesse, infui:

existir em

intersum, intěres, interesse, interfui:

estar entre; assistir

obsum, obes, obesse, obfui:

ser prejudicial

possum, potes, posse, potui:

poder; ser capaz

prōsum, prōdes, prōdesse, prōfui:

ser útil

subsum, subes, subesse, infui:

estar debaixo

supersum, supĕres, superesse, superfui :

restar

\section{SINTAXE DOS COMPOSTOS DE ESSE}

\section{1 - Abesse + a (ab) + ablativo :}

Antōnius a patriā abest.

Castra $a b$ urbe decem milia passuum aběrant.

\section{2 - Posse + infinitivo:}

Timor a militibus animum potuit repellère.

3 -Inesse: vide página 77, n. ${ }^{0} 5$. 
N.B. :

Os restantes compostos regem normalmente dativo.

EXERCÍCIOS :

Vénus era favorável (= assistia) aos Romanos.

Tu nunca (nunquam) faltas à escola.

Os Sabinos estavam a assistir (= assistiam) aos jogos, quando (cum) os Romanos raptaram (rapuërunt) as [suas] mulheres.

O frio (frigus, ŏris) e o vento são prejudiciais à agricultura.

É-me útil a tua amizade.

O livro estava debaixo da mesa.

Nenhum dos (de $+a b l$.) amigos te resta. 


\section{QUARTA DECLINAÇÃO: apenas SUBSTANTIVOS \\ dos três géneros}

I - Masculinos e femininos:

$$
\begin{aligned}
& \text { raptus, us rapto } \\
& \text { manus, us mão }
\end{aligned}
$$

Singular

N. raptus

V. raptus

Ac. raptum

G. raptus

D. raptui

Ab. raptu
Plural

raptus

raptus

raptus

raptuum

raptǐbus

raptǐbus

N. manus

V.

Ac.

G.

D.

Ab.

Decline:

maxĭmus exercitus um exército enorme

diuina quercus o carvalho profético 
II -- Neutros :

genu, genus joelho

cornu, cornus chifre

Singular

Plural

N. genu

genuă

V. genu

genuă

Ac. genu

genuă

G. genus

genuum

D. genui ou genu

genǐbus

Ab. genu

genǐbus

N. cornu

V.

Ac.

G.

D.

Ab.

\section{OBSERVAÇÃO}

O substantivo domus 'casa' apresenta a seguinte declinação:

\section{Singular}

N. domus

V. domus

Ac. domum

G. domus $o u$ domi

D. domui ou domō

Ab. domu ou domō
Plural

domus

domus

domus ou domōs

domuum ou domōrum

domíbus

domı̌bus

N.B. :

domi 'em casa; na pátria'

domi meae 'em minha casa'

domi bellique 'na paz e na guerra'

domi militiaeque 'na paz e na guerra' 


\section{RECITAÇÃO}

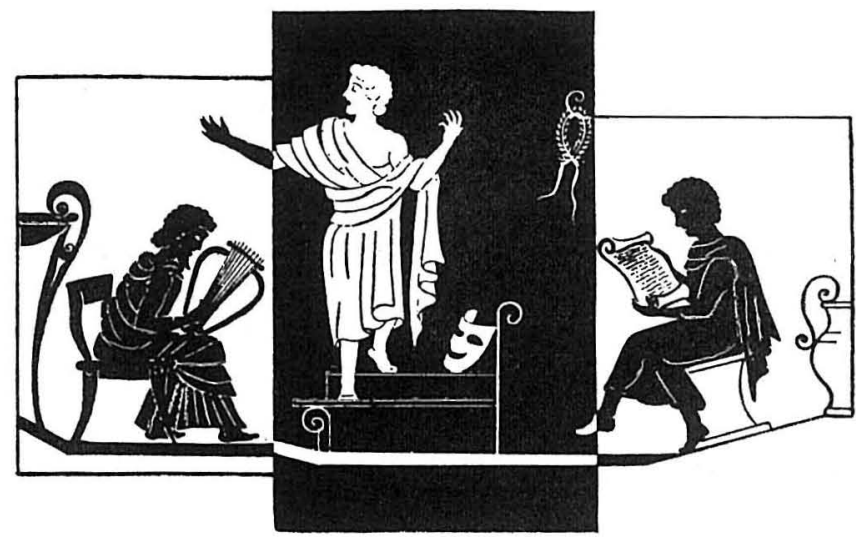

In tabernā quandō sumus ...

Bibit era, bibit erus, bibit miles, bibit clērus, bibit ille, bibit illa, bibit seruus cum ancilla, bibit uēlōx, bibit piger, bibit albus, bibit niger, bibit cōnstans, bibit uagus, bibit rudis, bibit magus,

bibit pauper et aegrōtus, bibit exul et ignōtus, bibit puer, bibit canus, bibit praesul et decānus, bibit soror, bibit frater, bibit anus, bibit mater, bibit ista, bibit ille, bibunt centum, bibunt mille. 


\section{CONJUGAÇÃO VERBAL}

Pretérito perfeito do indicativo

\section{Verbo ESSE:}

fuì eu fui ou tenho sido; eu estive ou tenho estado fuisti

fuit

fuĭmus

fuistis

fuērunt (ou fuēre)

I - vOZ ACTIVA:

Singular $\left\{\begin{array}{l}-(\mathrm{u}) \mathrm{i} \\ -(\mathrm{u}) \mathrm{ist} \\ -(\mathrm{u}) \mathrm{it}\end{array}\right.$

Plural $\left\{\begin{array}{l}-(\mathrm{u}) \breve{I m u s} \\ -(\mathrm{u}) \text { istis } \\ -(\mathrm{u}) \overline{\text { ërunt }} \text { ou }-(\mathrm{u}) \overline{\mathrm{r}} \mathrm{re}\end{array}\right.$

N.B.:

Sabido o enunciado do verbo (veja-se, para isso, um dicionário de latim-português), fácil se torna conjugar qualquer verbo neste tempo.

Assim, por exemplo:

laudō, laudās, laudāre, laudāuī, laudātum

pres. indicativo inf. pret. perf. supino

Do mesmo modo:

dèleō, dèlās, dèlère, dèlēuí, dèlètum moneō, monēs, monēre, monui, monìtum

legō, legis, legère, lēgi, lēctum

regōo, regis, regère, rēxi, rēctum

capiō, capis, capère, cēpi, captum

audiō, audis, audire, audiui, auditum 
laudāui

laudauisti

laudāuit

laudauŭmus

laudauistis

$\left\{\begin{array}{c}\text { laudauērunt } \\ \text { ou } \\ \text { laudauēre }\end{array}\right.$

lēgi

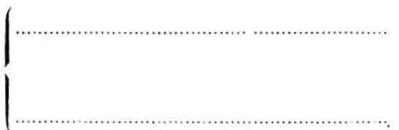

audiūi

\{ dēlēuì

monǔi
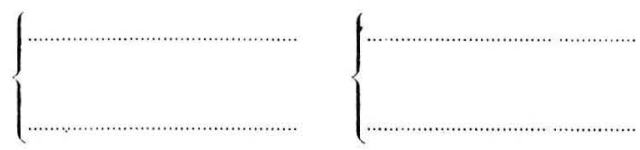

rēxi

cēpi

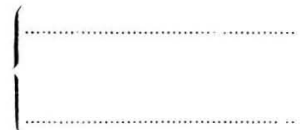


II - VOZ PASSIVA :

Particípio passado + pres. ind. de ESSE

N.B. :

SUPINO $\left\{\begin{array}{llccc}\text { laudātum } & \rightarrow & \text { part. pass. : laudātus, a, um } \\ \text { dēlētum } & \rightarrow & » & » & \text { dēlētus, a, um } \\ \text { monĭtum } & \rightarrow & » & » & \text { monĭtus, a, um } \\ \text { lēctum } & \rightarrow & » & » & \text { lēctus, a, um } \\ \text { rēctum } & \rightarrow & » & » & \text { rẽctus, a, um } \\ \text { captum } & \rightarrow & » & » & \text { captus, a, um } \\ \text { auditum } & \rightarrow & » & \gg & \text { auditus, a, um }\end{array}\right.$

CONJUGAÇÃO:

laudātus, laudāta, laudātum sum

$\begin{array}{llll}\gg & \gg & \gg & \text { es } \\ \gg & \gg & \gg & \text { est }\end{array}$

laudātî, laudātae, laudāta sumus

$\begin{array}{llll}\gg & » & \text { estis } \\ \gg & \gg & \gg & \text { sunt }\end{array}$

N.B. :

laudātus sum $=$ eu FUI louvado 


\section{Dē Ganymēdis raptu}

\section{Ganymēèes, deörum pincerna}

Olim erat in Phrygiã adulescentŭlus fōrmōsissǐmus, nơmǐne Ganymēdēs, qui Trōis rēgis erat filius. Aliquandō, dum ouēs in monte Idā unā cum aequalîbus pascēbat, raptus est a Ioue in aquîlam mutātō atque in Olympum subductus. Ibi Ganymēdēs in deōrum symposiō uinum temperābat ${ }^{1}$ et nectar ministrābat et curam gerēbat conuiuii. Nam Hēbē, Iunōnis filia, quae biběre dis ministrābat, ante omnēs ridicŭlē lapsa, eōrum risum mōuit. Ităque ērubēscēns nōn sōlum ē symposiō discessit, sed etiam in perpetuum sē muněre abdicāuit.

\section{Iunō, zēloty̆pa uxor}

In Olympō igĭtur Ganymēdēs in sē admiratiōnem omnium deōrum dearumque statim traduxit. Iunō autem, quae odium in Trōiānōs habēbat, Ganymēdem aemŭlans furēbat atque Iouem saepe obiurgābat: "Cur, impŭdēns, puĕrum istum ${ }^{2} \mathrm{ab}$ Ida monte raptum huc subduxisti? Nōn satis habēs, si in terram, moeche, descendis moechatūrus in taurum ${ }^{3}$ uel cycnum ${ }^{4}$ mutātus? Attămen Eurōpa et Lēda in terrā manent: sed puěrum istum rapuisti et huc ēuolauisti; et nōbiscum nunc habĭtat. Tantane 5 tibi 6 erat pincernārum penuria? Vulcānus, filius noster, idōneus est ad uinum tibi ministrandum ${ }^{7 . »}$ Tum Iuppĭter: «Nihil aliud oportēbat, mōrōsa, nisi Vulcānum filium tuum uinum nōbis ministrāre claudicantem ${ }^{8}$, a fornāce uenientem, strictūris adhuc opertum ac fuligĭne nigrā infectum faciem 9 !»

1 Era de boa norma servir aos convivas, num banquete, o vinho misturado com água, numa proporção previamente determinada pelo presidente do festim (rēx conuiuii).

$2 \mathrm{O}$ pronome iste, ista, istud tem frequentemente um valor depreciativo.

3 Vd. p. 144.

4 Vd. p. 145.

5 Vd. pp. 69-71.

6 Vd. p. 77, 2.

7 idoneus ad uinum ... ministrandum "capaz de servir o vinho».

8 Vulcano era o único deus a quem faltava o apanágio da beleza. Manco e disforme, instalou na ilha de Lemnos uma grande forja, onde, com a ajuda dos Ciclopes, trabalhava os metais e fabricava toda a sorte de jóias e armas para os deuses.

9 infectum faciem "sujo quanto à face; com a cara toda suja»: faciem é um acusativo de relação. 


\section{VOCABULÁRIO}

abdicāre: renunciar

sē abdicāre [ + abl.]: renunciar

a; demitir-se de

adhuc: ainda

admiratiō, ōnis: admiração

adulescentŭlus, i: jovem

aemŭlans, antis [+ acusat.]: que tem inveja ou ciúmes de; com ciúmes de

aequālēs, ium: companheiros ( $d a$ mesma idade)

attămen: pelo menos

claudicans, antis: que é manco;

a coxear

cur: por que motivo?

cura, ae: cuidado

curam gerĕre: tomar a direcção

dēscendĕre: descer

discēděre: retirar-se

pret. perf. ind. discessi

èrubēscēns, entis: que cora de vergonha

ēuolāre: voar

fornax, ācis: forja

fuligō, ĭnis: fuligem

furĕre: estar ou andar furioso

Ganymēdēs, is: Ganimedes

Hēbē, ès: Hebe

huc: para aqui

Ida, ae: Ida

igitur: portanto

impǔdēns, entis: desavergonhado voc. impŭdens: ó meu descarado!

infectus, a, um: sujo

ităque: por isso

lapsus, a, um: que escorregou manēre: permanecer; continuar ministrāre: servir (como criado) bibere ministrāre: servir de beber; desempenhar as funções de escanção

moechatūrus, a, um: que vai cometer adultério; para a devassidão

moechus, i: adúltero

voc. moeche: ó meu devasso!

mōrōsus, a, um: rabugento

voc. mōrōsa: ó minha chata!

mouēre: provocar

pret. perf. ind. mōui

munus, ěris: cargo

niger, ra, rum: negro

nisi: a não ser; senão (vd. oportēre)

obiurgāre: censurar

odium, ii: ódio

odium in alǐquem habēre: odiar alguém

opertus, a, um: coberto

oportēre: convir; ser necessário nihil aliud oportēbat nisi: não faltava mais nada, senão...; era só o que faltava, que...

pascěre: apascentar

penuria, ae: escassez

tanta penuria: tanta falta

perpetuus, a, um: contínuo

in perpetuum: para sempre

Phrygia, ae: Frígia

pincerna, ae: copeiro; escanção

rapěre: raptar

pret. perf. ind. rapui 
raptus, a, um: raptado

ridicǔlē: de maneira ridicula

risus, us: riso; risada

saepe: frequentemente

satis: bastante

satis habēre: bastar

nōn satis habēs: não te basta

statim: imediatamente; logo

strictūra, ae: escória (pequeno pedaço de metal em brasa)

subducěre: trazer ou levar; part. pass. subductus, a, um

symposium, ii: banquete; festim tantus, a, um: tâo grande; tamanho

temperāre: misturar

uinum temperāre: fazer a mistura de vinho com água

traducĕre: fazer passar através de in sē admiratiōnem traducěre: atrair a si a admiração

Trōs, ōis: Trós

ueniēns, entis: que vem; vindo

unā: juntamente

unā cum [+ abl.]: na companhia de

zēloty̆pa, ae: ciumenta

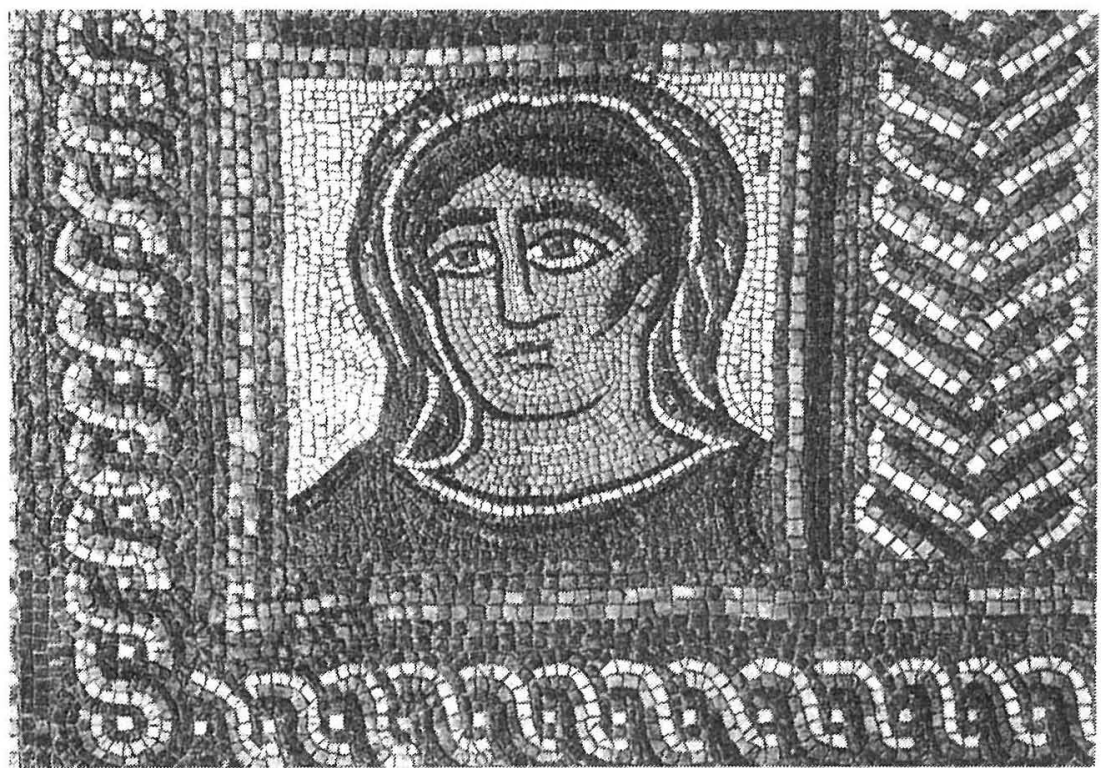

CONÍMBRIGA - O Inverno 


\section{CONJUGAÇÃO VERBAL}

Pretérito mais-que-perfeito do indicativo

Verbo ESSE:

$\begin{array}{ll}\text { fu - ĕram } & f u \text { - erāmus } \\ \mathrm{fu} \text { - ĕras } & \mathrm{fu} \text { - erātis } \\ \mathrm{fu} \text { - ĕrat } & \mathrm{fu} \text { - ĕrant }\end{array}$

] - VOZ ACTIVA:

$\begin{array}{ll}\text { laudau - ĕram } & \text { laudau - erāmus } \\ \text { laudau - ĕras } & \text { laudau - erātis } \\ \text { laudau - ěrat } & \text { laudau - ěrant }\end{array}$

dēlēuěram

monuěram

lēgěram

rēxěram 
II - vOZ PASSIVA :

Particípio passado + pret. imperf. ind. de ESSE Vd. p. 156.

CONJUGAÇÃO:

$\begin{array}{ccc}\text { laudātus, a, um } & \text { eram } \\ » \quad \text { " } & \text { eras } \\ » \quad » \quad \text { erat }\end{array}$

laudāti, ae, a erāmus

$\begin{array}{lll}» \quad » & \text { erātis } \\ » \quad » & \text { erant }\end{array}$




\section{ABLATIVO ABSOLUTO ou ORACIONAL}

O ablativo absoluto é uma construção em que os principais elementos se encontram em ablativo, e que, por ser independente, pode ser eliminada sem alterar o sentido da frase ou perturbar a sua sintaxe.

Também se chama oracional, por ser resolúvel numa oração circunstancial, nomeadamente, temporal, causal, temporal-causal, concessiva, etc., conforme o contexto em que vem inserido.

EXEMPLOS:

Caesăre duce, ... «Sendo César o comandante; sob o comando de César, ...»

Mē puèrō, ... «Sendo eu criança; quando eu era criança; na minha infância; visto eu ser uma criança; apesar de eu ser criança, ...»

$T \bar{e}$ aegrō,$\ldots$ «Estando tu doente; quando estavas doente; visto estares doente; embora estejas doente, ...»

Serēnō caelō, ... «Estando o céu sereno; com bom tempo, ...»

Pace factā, ... «Feita a paz; quando ou visto que a paz foi feita; embora a paz tivesse sido feita, ...»

Patre absente, ... «Estando o pai ausente; na ausência do pai, ...»

Hāc ōratiōne habĭtā, ... «Proferido este discurso; etc.»

Quibus (=illis) rēbus omissis, ... «Omitidas essas coisas (= omitidos esses factos); com a omissão desses factos; etc.» 
E X E R C Í C I O S :

\section{Traduza:}

Të sene, ...

Nōbis iudič̌bus, ...

Cicerōne cōnsǔle, ...

L. (=Luciō) Domitiō, Ap. (=Apiō) Claudiō cōss. (=cōnsulibus), ...

Littěris scriptis,

Vrbe captā, ...

Tarquiniō Superbō rēgnante, ...

Rēgǐbus ab Vrbe (= Rōmā) exactis, ...

Hōc proeliō factō, ... 
His rēbus cognŭtis, ...

Quibus rēbus confectis, ...

Quō consiliō dimisssō, ...

His uerbis a iudice auditis, ...

Eōrum satisfactiōnibus acceptis, ...

\section{VOCABULÁRIO}

acceptus, a, um: aceite auditus, a, um: ouvido

captus, a, um: capturado; tomado cognitus, a, um: conhecido confectus, a, um: realizado cōnsilium, ii: assembleia dimissus, a, um: dissolvido; encerrado

exactus, a, um: expulso factus, a, um: feito; travado iudex, Icis: juiz proelium, ii: combate rēgnans, antis: que reina; reinando satisfactiō, ōnis: desculpa scriptus, a, um: escrito senex, senis: velho uerbum, i: palavra 


\section{Verta para latim:}

a)

Sob o teu comando (= sendo tu o comandante), ...

No reinado de Tibério (= reinando Tibério: Tiberius, ii), ...

Durante o governo de Augusto (imperrans, antis; Augustus, i), ...

Sem o pai saber (ignārus, a, um), ...

No consulado de César (= sendo César cônsul), ...

Com a proteç̧ão de Deus (= sendo Deus propício: propitius, $a, u m), \ldots$

Escutado (praeceptus, a, um) o seu (= dele) discurso, ...

Tomadas estas decisões (= resolvidas estas coisas: constitūtus, $a, u m), \ldots$ 
Conhecido esse facto ( $=$ a qual coisa conhecida), ...

Cometidas estas façanhas (= as quais coisas cometidas: gestus, $a$, um; vd. p. 84) ...

b)

Com a doença do pai (= estando o pai doente), os filhos faltaram (vd. pp. 149-150) à escola (vd. p. 47, OBSERVAÇÃo).

Raptadas (raptus, $a$, um) as Sabinas (= mulheres sabinas), quando assistiam (vd. pp. 149-150) aos Jogos (vd. p. 47, obSERVAÇÃo), os pais e os maridos (marïtus, i) declararam (indicěre: pret. perf. indixi) guerra aos Romanos.

Após a tomada e o incêndio de Tróia (=tomada e incendiada Tróia: captus, a, um; incēnsus, $a, u m$ ), Eneias navegou (nauigāre) para Itália, na companhia do (una cum + abl.) pai, do filho e de alguns (nōnnullus, a, um) companheiros (socius, ii). 
Conhecido o plano (cōnsilium, ii) dos inimigos (hostēs, ium), o comandante conduziu (ducĕre: pret. perf. duxi) as tropas (vd. p. 16) para a cidade. Em seguida (deinde), vencidos (uictus, $a$, um) os inimigos e recebidos (acceptus, $a, u m$ ) os reféns (obses, ìdis), reconduziu (reducère) o exército (exerč̆tus, us) para o mar.

Reparados (refectus, $a, u m$ ) e lançados à água (dēductus, $a, u m$ ) os navios (nauis, is: feminino), navegou em direcção à pátria.

Desencadeada (coortus, $a$, um) uma violenta (maximus, $a, u m$ ) tempestade (tempestas, ātis), quase (prope) toda a frota (classis, is) foi destruída (affligěre: part. pass. afflictus, a, um) pelas ondas (vd. p. 38, ao fundo).

Levadas (allātus, a, um) as notícias (nuntium, ii) do desastre (cladēs, is) para Roma (note que com o nome de cidades não deve usar preposição), foi enorme (maximus, a, um) a aflição (maestitia, ae) de todos. 


\section{A EXPRESSÃO casar com}

Verte-se para latim das duas maneiras seguintes:

1. (quando o sujeito é o homem) ducĕre uxōrem ou ducëre in matrimōnium + nome da mulher em acusativo;

2. (quando o sujeito é a mulher) nubĕre + dativo do nome do homem.

EXEMPLOS:

1. O célebre orador Cícero casou com Terência.

Cicěrō ille ōrātor uxōrem Terentiam duxit.

Ou:

Cicěrō ille ōrātor in matrimōnium Terentiam duxit.

2. Terência casou com o célebre orador Cícero.

Terentia Cicerōni illi ōratōri nupsit.

1. O filósofo Sócrates tinha casado com Xantipa.

Sōcrătēs philosŏphus Xanthippēn 1 duxĕrat uxōrem.

$\mathrm{Ou}$ :

Sōcrătēs philosǒphus Xanthippēn in matrimōnium duxěrat.

2. Xantipa casara com o filósofo Sócrates.

Xanthippē Sōcrăti philosǒphō nupsĕrat.

1 Note a desinência de ac. sing. -ẽn, de origem grega (= lat. -ăm). 
E X E R C í C I O S :

$\mathrm{Eu}$ caso contigo.

1.

\section{$\mathrm{Ou}$ :}

2.

Tu casas comigo.

1.

Ou:

2.

Paulo casava com Lúcia.

1.

Ou:

Lúcia vai casar (= casará) com Paulo.

2.

Júlio tinha casado com Cláudia.

1.

$\mathrm{Ou}$ : 
Cláudia tinha casado com Júlio.

2.

Marco (Marcus) António casou com Cleópatra (Cleopătra, ae), rainha do Egipto (= dos Egípcios: Aegyptii, ōrum).

1.

\section{$\mathrm{Ou}$ :}

Cleópatra, rainha do Egipto, casou com Marco António.

2.

Os teus dois (duo) filhos casaram com as filhas de meu amigo Paulo.

1.

$\mathrm{Ou}$ :

As duas (duae) filhas de meu amigo Paulo casaram com teus filhos.

2. 


\section{I — Dē Parĭde, Priămi et Hecŭbae filiō}

In Asia ōlim erat praeclārum oppĭdum Trōia, cuius rēx, nōmǐne Priămus, in matrimōnium duxěrat Hecŭbam. Priămō et Hecŭbae libĕri multi atque clari fuērunt. Inter filiōs erat Paris, cui Alexander nōmen quoque erat. Dei autem Priămō Trōiae exscidium dēnuntiauērunt: $« \overline{\mathrm{O}}$ Priăme, filius tuus paruus Alexander Trōiae erit exscidiō 2. Quarē tē iubēmus ex oppĭdō eum expellĕre ${ }^{3}$.» Verbis deōrum exterrĭtus et uxōris lacrŭmis resistēns, Priămus seruum fidum uocat et: «Filium meum Parǐdem», inquit, «ex oppǐdō porta et in locō dēsertō relinque ${ }^{4}$, quia

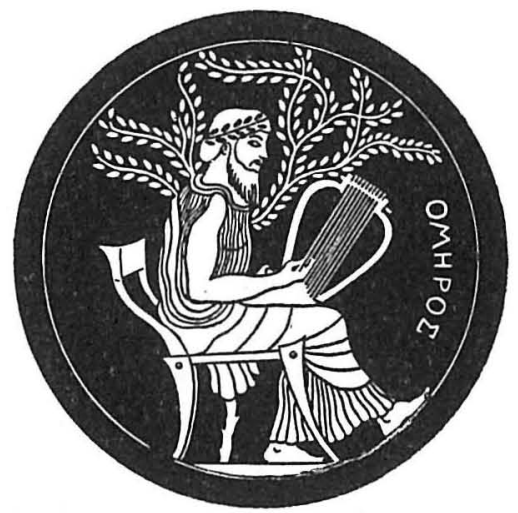
Trōiae erit periculōsus.» Seruus sic fēcit, sed - mirabǐle audìtu! ${ }^{5}$ puer nōn sōlum bēstiis nōn dēuorātus est, sed etiam inuentus est ab agricŏlā quōdam qui in casam suam eum portāuit. Ibi agricŏlae uxor Alexandrum magnā cum curā èducāuit. Ităque omnēs Trōiāni Parǐdem mortuum existimauērunt et Priămi cōnsilium oppĭdum Trōiam nōn seruāuit. Nam multis post annis Alexander, iam uir pulcher et ualīdus, belli Trōiāni causa erit.

\section{II - Dē Pēlĕi Thetidisque nuptiis ac Discordiae pōmō}

In Thessalia habitābat Pēlěus quem Iuppǐter iussit in matrimōnium ducĕre marīnam nympham Theť̃dem. Nuptiae celebrantur. apud Pēlěum: Thessalia tōta domum frequentat; ex Olympō dēscendunt dei deaeque; undǐque dōna feruntur; rēgia fulgenti aurō atque argentō splendet; candet ebur in soliis; - mēnsae pōcŭlis collūcent; omnēs dei et mortālēs nuptiis gaudent. Dea Discordia autem ad conuiuium nōn 
inuitāta erat ${ }^{6}$, nam in nuptiis discordia esse nōn dēbet. Cum omnēs conuīuae discumbēbant, Discordia repentē compāret et irāta in medium conuiuium iactat aureum pōmum et: «Dētur 7», inquit, «pulcherrĭmae.» Sic Discordia tumultum in conuiuuas intǔlit, nam deae omnēs conclamābant: «Ego pulcherrǐma sum, quamŏbrem aureum pōmum mihi erit.» Tandem pulcherrĭmae deae, Iunō et Minerua et Venus, ad Iouem ueniunt et: «Iuppǐter», inquiunt, "Discordia in rixam nōs concitāuit: tu in hanc rem arbǐter eris. Nōbis dic 8 : Quae nostrum est pulcherrĭma?» Iuppĭter autem deārum iram timēns illis subrīdet uultu quō caelum tempestatēsque serēnābat et: «In hanc rixam», inquit, «arbǐter nōn erō, sed Paris, Priămi filius; ad eum mittam nuntium meum: per Mercurium iubēbō Parĭdem dēligěre pulcherrǐmam deam cui aureum pōmum dōnabitur.»

\section{III - Dē Parìdis iudiciō}

His uerbis audìtis, Iunō et Minerua et Venus cum Mercuriō ex Olympō statim dēscendunt ad Parǐdem qui forte in Idā monte ouēs lentus ${ }^{9}$ pascēbat. «Paris», deae inquiunt, «ab Ioue arbĭter rixae nostrae dēlēctus es. Nam hoc aureum pōmum erit pulcherrìmae. Dic: Cui nostrum id das?» Deinde Iunō et Minerua ei maria montēsque pollicentur: «Tibi», Iunō inquit, «magnam potentiam prōmittō»; et Minerua exclāmat: «Meā opĕrā omnium homǐnum sapientissŭmus eris!» Venus autem ad dōnandum 10 nihil habēns: «Si aureum pōmum mihi dabis», inquit, «tibi ōlim dabō pulcherrǐmae muliěris amōrem.» His uerbis dictis, Paris Venĕri aureum pōmum haud cunctanter dat. Iunō et Minerua iratissĭmae fuērunt et ex eō tempǒre odium in Parĭdem atque omnēs Trōiānōs habuērunt. Nam in altā Iunōnis mente semper mansit repostum ${ }^{11}$ Parĭdis iudicium sprētaeque fōrmae iniuria 12.

\section{IV - Dē Parìdis agnitiōne}

Paris autem a pueritiā in agris habitāuit oriğnem suam ignōrans. Cum iam uir pulcher et ualĭdus erat, eius pater, Priămus rēx, ludōs magnōs parāuit et ad eōs agricŏlas inuitāuit. Paris ex agris in oppǐdum Trōiam uēnit. Tum Venus, erga Parřdem semper grata atque prōmissi sui memor, Priămi oculōs ad Pař̃dem in media turba stantem uertit. Senex rēx filium agnōscit et magnō cum gaudiō/exclāmat: «Hecŭba, filius, quem mortuum existimabāmus, uiuus est. Ecce Paris noster!» 
Sic Paris in oppĩdō Trōiā cum parentǐbus, fratrĭbus sorōribusque laetus itěrum habitāuit. In Olympō autem Iunō aeternum uulnus sub pectŏre seruābat, nam Parīdis iudicium sprētaeque fōrmae iniuria ex anı̌mō suō nōndum ceciděrant. His accensa, haec sēcum uoluēbat: «Mēne et deōrum rēgīnam et Iouis uxōrem Venus irridēbit? An ego dē odiō in Parǐdem istum ${ }^{13}$ uicta dēsistam? Bellum ingēns cum Trōiānis geram: per mē genus inuisum ēuertētur et alta Trōia a fundamentis fumābit.»

\section{V - Dẽ Helěnae, Menelāi uxōris, raptu}

Hōc tempŏre erat in Graeciā clarum oppĭdum, nōmǐne Spartă, ubi rēgnābat Menelāus, frater Agamemnŏnis Mycēnārum rēgis. Menelāus in matrimōnium duxĕrat pulcherrĭmam Helěnam; Agamemnōn uxōrem habēbat Clytaemnēstram, Helěnae sorōrem.

Graeci ad ōras Trōiae saepe nauigābant, sed Trōiānōs nōn amābant, quod rēx Priămus nautas Graecōs iubēbat tribūta Trōiānis penděre. Sed, quia oppǐdum Trōia erat ualǐdum atque potēns, Priămus Graecōs nōn timēbat et eōrum inuidiam parui faciēbat 14 .

Paris aliquandō ad Graeciam nauigāuit: ibi, postquam multas urbēs uisitāuit, ad Spartanōrum oppǐdum aduēnit et a Menelāō honorifícē acceptus est. In Menelāi rēgiā Helěnam uidet et Veněris opěrā fōrmă paene diuīnă rēginae eius anı̌mum uehementer mōuit. Menelāō absente Paris rēginnae persuādet ut sēcum ad Trōiam fugiat 15. Tandem Helĕna, amōre Parĭdis capta, cum Trōiānis ex Graecia in Asiam nauigāuit. Interea Menelāus dē iniuriā irātus ad arma uocāuit Graecōrum princīpēs inter quōs erant Agamemnōn, Menelāi frater, et Achilles, Pēlēi Thetidisque filius, et dolōsus Ulixes, paruae insŭlae Ithăcae rēx. Sic nōn sōlum Pēlèi nuptiae et aureum pōmum, sed etiam Parĭdis iudicium et Iunōnis Mineruaeque odium in Trōiānōs et Venĕris prōmissum exscidii Trōiae causa fuērunt, postquam Graeci et Trōiāni decem annōs 16 apud misěrum oppidum pugnauērunt.

\section{VI - Dē Iphigenia}

Graeci in urbe Aulīde congregāti multas nauēs parant et Agamemnŏna 17 ducem legunt. Tamen Graecōrum classis iam ad nauigandum 18 parātă uentis aduersis retinēbātur. Nam dux Agamemnōn in siluā ceruam 
Diānae sacram imprudenter necauěrat. Quä dê causā dea irăta uentôs aduersōs concitauĕrat. Interea in Graecōrum castris iam magna cibi inopia erat et milĭtēs, duci offensi, eum ob moram culpābant. Tum Calchas uatēs, a Graecis interrogātus, causam morae patefēcit. «Diāna», inquit, «prō ceruā necātā uitam Iphigenīae, Agamemnŏnis filiae, postǔlat: puella in arā deae immolāri dēbet.» Hoc audiens Agamemnōn lacrǐmis multis frustra sacrificium iustum esse negat 19: nam Iphigeniam ualdē amābat. Vniuersi Graeci autem sacrificium postǔlant. Tandem pater filiam ad castra uenire iubet et inuïtus immŏlat. Statim uentus secundus flauit et Graeci ad Trōiam nauigāre potuērunt.

(Continua.)

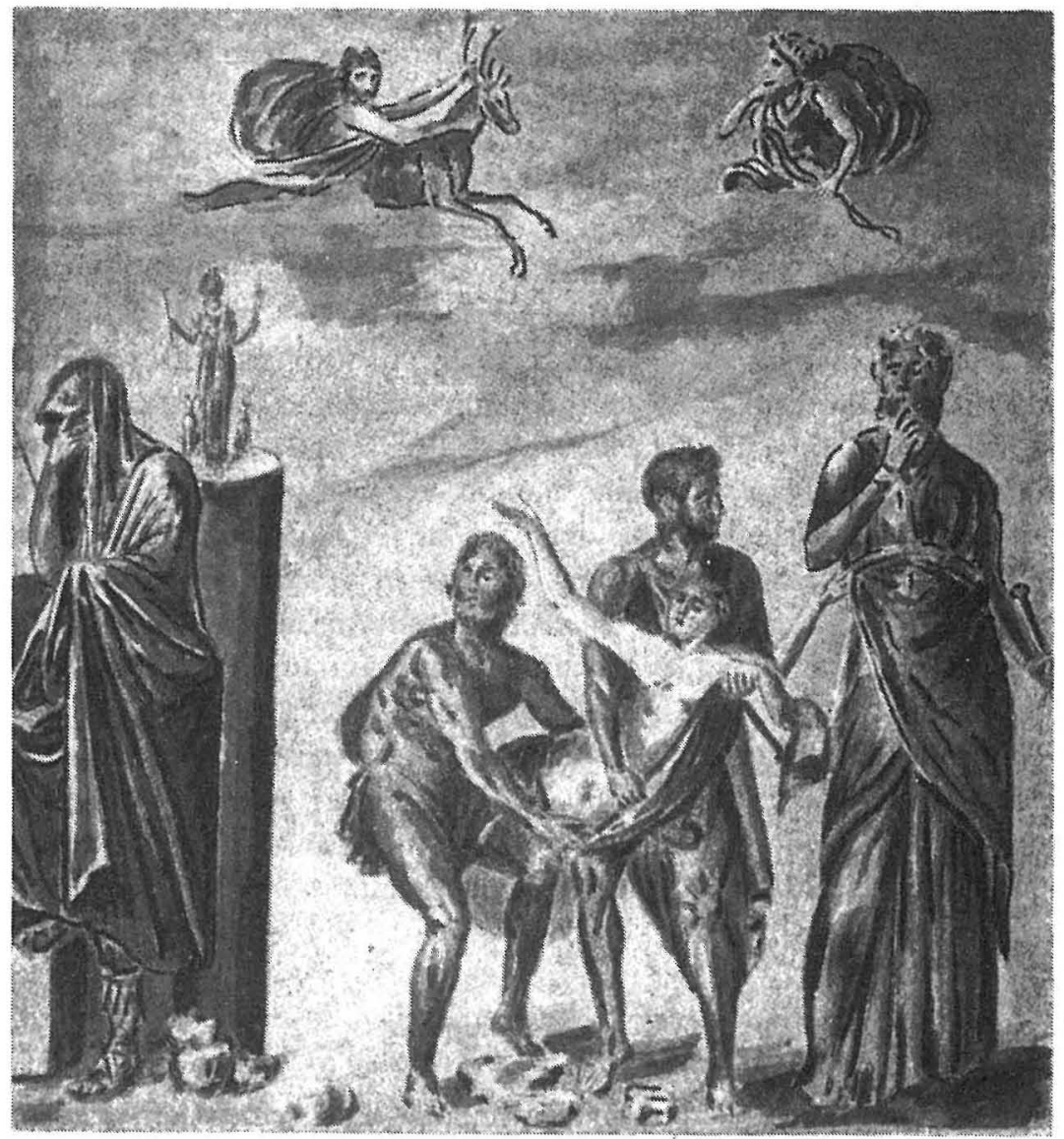

POMPEIOS: Sacrifício de Ifigénia. 


\section{NOTAS}

1 ab ōuõ 'desde o ovo; desde o princípio': vd., no final deste livro, Horácio, Dè arte poètica, vv. 136-152 ('A epopeia'), em especial v. 147 e respectivo comentário (nota iii).

2 vd. p. 181, 3.

3 tē iubēmus... expellère 'ordenamos-te que expulses': o verbo iubēre 'ordenar' constrói-se com oração infinitiva (predicado no infinit. e suj. em acusativo).

4 porta et... relinque: imperativos de portäre e relinquère. vilha!'.

5 mirabile auditu 'Oh, (que) coisa maravilhosa de se ouvir! Oh, (que) mara-

6 nonn inuitāta erat 'não tinha sido convidada'.

7 dētur 'que seja dada': pres. do conj. passivo de dare.

8 nōbis dic 'diz-nos': dic imperativo de dicĕre.

9 lentus 'descuidoso; calmo': este adj. poderá ser traduzido por um advérbio.

10 ad dōnandum 'para oferecer': expressão de fim.

11 in altā... mente semper mansit repostum 'ficou sempre profundamente gravado no espírito'.

12 sprētae... förmae iniuria 'a ofensa à sua beleza desprezada'.

13 istum: o pron. iste 'esse' é frequentemente usado com valor depreciativo.

14 parui facère 'fazer pouco caso de': parui é genitivo de preço.

15 persuadère + dativo $+u t \ldots$ conjuntivo 'persuadir alguém a que...'

16 note o acusativo de duração decem annōs.

17 Agamemnŏna: acusativo do singular com desinência grega (-ă = lat. -em).

18 ad nauigandum 'para navegar; para se fazer ao mar': vide supra, n. 10.

19 negat 'afirma que... não...'

\section{VOCABULÁRIO}

absēns, entis: que está ausente accēnsus, a, um: inflamado; irritado

acceptus, a; um: vd. accipěre accipěre: acolher; receber part. pass. acceptus aduenire: chegar agnitiō, ōnis: reconhecimento 
agnöscëre: reconhecer

Alexander, ri: Alexandre

altus, a, um: alto; poderoso; altivo

anǐmus, i: alma

annus, i: ano

multis post annis: muitos anos depois

ara, ae: altar

arbitter, tri: árbitro; juiz

argentum, i: prata

arma, ōrum: armas

ad arma uocāre: convocar para a luta

audiēns, entis: que ouve; ao ouvir Aulis, İdis: Aulida

aureus, a, um: dourado; de ouro aurum, i: ouro

autem: ora; porém

bēstia, ae: fera; animal feroz

caděre: cair

pret. m.-q.-perf. do ind. cecidĕram; ex anĭmō cadĕre: ser

, esquecido

Calchas, antis: Calcas

candēre: brilhar (como a neve)

captus, a, um: dominado

casa, ae: cabana

cecidĕrant: $v d$. cadĕre

celebrāre: celebrar

cerua, ae: corça

cibus, i: alimento; mantimento(s)

collucēre: resplandecer

comparēre: aparecer; surgir

concitāre: provocar; fazer surgir ;

desencadear

in rixam alíquem concitāre:

lançar alguém numa disputa

conclamāre: gritar d̀ uma

congregātus, a, um: reunido cơnsilium, ii: decisão

conuiua, ae: conviva; convidado

conuiuium, ii: banquete

in medium conuiuium: para $o$

meio do banquete

cum [+ ind.]: quando

cunctanter: com hesitação

haud cunctanter: sem hesitar

cura, ae: cuidado(s)

dēbēre: dever

deinde: seguidamente

dēligĕre: escolher

dēnuntiāre: anunciar; dar a conhecer

dēscenděre: descer

dēsistĕre: desistir

dēuorāre: devorar

part. pass. dēuorātus, a, um dictus, a, um: dito

discordia, ae: discórdia

discumběre: deitar-se; tomar lugar

à mesa; estar à mesa

dolōsus, a, um: ardiloso; astuto

dōnāre: oferecer

dōnum, i: presente; oferta

ebur, ŏris: marfim

ecce: eis!

ēducāre: criar

erga [+ acusat.]: com respeito $a$; relativamente; para com

existimāre: julgar; considerar

exscidium, ii: destruição

exterritus, a, um: aterrado; apavorado

ēuertĕre: derrubar; aniquilar

facěre: fazer

pret. perf. do ind. fëci

ferre: trazer

3. ${ }^{a} \mathrm{p}$. pl. do ind. do pres. ferunt fidus, a, um: fiel; de confiança 
flāre: soprar

fōrma, ae: formosura

forte: por acaso

frequentāre: encher; apinhar

frustra: em vão

fulgēns, entis: fulgente; brilhante

fulgenti auro: com o fulgor do ouro

fumāre: fumegar

fundamentum, i: base; no $\mathrm{pl}$. alicerces

gaudēre: regozijar-se

gaudium, ii: regozijo; alegria

genus, ěris: raça

gerěre: levar; fazer

bellum cum alĭquō gerěre: fazer

uma guerra contra alguém

habēns, entis: que tem; tendo

haud [+ adj. ou advérbio]: não

Hecŭba, ae: Hécuba

Helěna, ae: Helena (note a acentuação proparoxítona do vocábulo latino)

honorificē: com distinção; com deferência

iactāre: lançar; arremessar

Ida, ae: Ida

ignorans antis: que ignora; ignorando

immolāre: imolar; sacrificar

inf. pres. pass. immolāri

imprudenter: por ignorância; sem saber

in [ + acusat. de pessoa]: contra inuitāre: convidar

inferre: levar

pret. perf. ind. intŭli

tumultum in conuiuas inferre:

lançar a confusão entre os convidados ingèns, entis: enorme

bellum ingēns: guerra terrivel

iniuria, ae: ofensa; ultraje

inopia, ae: falta; carência

interea: entretanto

intŭlit: $v d$. inferre

inuenire: encontrar

part. pass. inuentus, a, um

inuidia, ae: inveja; hostilidade

inuīsus, a, um: odioso

inuitus, a, um; constrangido ; contrariado; à força

Iphigenia, ae: Ifigénia (note a acentuação do vocábulo latino) ira, ae: cólera iratisšmus, a, um: muito zangado ităque: assim; deste modo itěrum: de novo; novamente Ithăca, ae: Ítaca iudicium, ii: julgamento laetus, a, um: alegre, feliz legĕre: escolher marinus, a, um: marinho memor, ŏris: que se lembra; recordado

Menelāus, āi: Menelau miser, èra, um: infeliz mora, ae: demora mittěre: mandar; enviar mortālēs. ium: os mortais; os homens

mortuus, ua, uum: morto

mouēre: perturbar

narrāre: contar

necāre: matar

nihil: nada

nōndum: ainda não

nuntius, ii: mensageiro

nuptiae, ārum: núpcias; bodas nupciais 
ob [+ acusat.]: por causa de ocŭlus, i: olho

odium, ii: ódio odium in alĭquem habēre: odiar alguém

offensus, a, um: ofendido

alicui offensus: ofendido com alguém

ōlim: um dia (no passado ou no futuro)

opěra, ae: trabalho; serviço meā opĕrā: graças a mim

alicuius opěrā: graças a alguém oppǐdum, i: fortaleza; cidade

ōra, ae: costa (marítima)

orīgō, ĭnis: origem

paene: quase

parāre: preparar; aprontar; organizar

parentēs, um: pais (= pai e mãe)

Paris, ídis: Páris

paruus, a, um: pequeno

pascěre: apascentar

patêfacěre: revelar

pret. pert. ind. patēfēci

pectus, ŏris: peito

sub pectŏre: no fundo do coração; no íntimo

Pēleus, èi: Peleu

pendĕre: pagar

per [ + acusat. de pessoa]: por intermédio de

periculōsus, a, um: perigoso

pōcŭlum, i: copo; taça

pollicēri (só forma passiva): pro-

meter

maria montēsque pollicēri:

prometer mundos e fundos;

prometer este mundo $e$ o outro (à letra: prometer montes e mares)

pōmum, i: fruto; pomo

portāre: levar

posse: poder

pret. perf. ind. potui

postulāre: exigir

potēns, entis: poderoso

potentia, ae: poder; poderio; força

potueerunt: $v d$. posse

praeclārus, a, um: famoso; rico

Priămus, i: Príamo

princeps, ĭpis: chefe

prō [+ ablat.]: em troca de

prōmissum, i: promessa

prōmittěre: prometer

pueritia, ae: infância

pulcher, ra, rum: belo

pulcherrimus, a, um: muito belo;

o mais belo

quia: porque

quod: porque

quoque: também

raptus, us: rapto

rēgia, ae: palácio real

relinquĕre: abandonar

repentē: subitamente

resistēns, entis: resistindo

retinēre: reter

rixa, ae: contenda; disputa

sacer, ra, rum: sagrado; consagrado

sapientissimus, a, um: muito sábio; o mais sábio

secundus, a, um: favorável; de feição

senex, senis: velho; idoso

serēnāre: serenar

seruāre: conservar

sic: assim; deste modo 
solium, ii: assento; trono

splendēre: cintilar; brilhar; reluzir stans, antis: que está (de pé)

statim: imediatamente; logo

subridēe: sorrir

tamen: todavia

tandem: por fim

tempestas, ātis: tempestade

tempus, orris: tempo

hōc tempŏre; nesta ocasião; por esta altura

Thessalia, ae: Tessália

Thetis, îdis: Tétis

timēns, entis: que teme; temendo timēre: recear

tōtus, a, um: todo; inteiro ; em peso

tribūtum, i: imposto

Trōiānus, a, um: troiano; de Tróia tumultus, us: desordem; confusão turba, ae: multidão

in mediā turbā: no meio da multidão

ualdē: muito; particularmente

ualidus, a, um: forte

uatēs, is: adivinho uehementer: com violência; profundamente

Venus, ěris: Vénus

uerbum, i: palavra

uertěre: voltar; virar

ocǔlōs uertěre: dirigir o olhar

uictus, a, um: vencido

uiuus, a, um: vivo

undique: de todos os lados

uniuersus, a, um: todo inteiro; no

pl. todos juntos; todos sem excepção

uocāre: chamar; mandar vir

uoluěre: revolver

haec sēcum uoluĕre: revolver estes pensamentos consigo mesmo

uulnus, ěris: ferida

aeternum uulnus: ferida que não sara

uultus, us: expressão do rosto; rosto

uultu quō: com aquela expressão com que

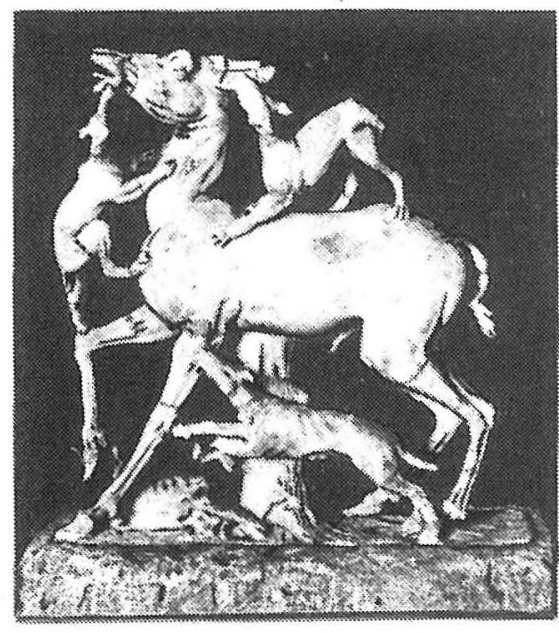

HERCULANO (Itália)

Veado

atacado por cães 
1 - Esse + dativo «existir para... = ter»: vide página 77,2

Eu tenho um livro.

$\downarrow$
Existe para mim um livro.

Est mihi liber.

$\frac{\text { Meu pai tem uma casa. }}{\downarrow}$

Est patri meō domus.

2-Esse + genitivo «a) ser de; b) ser próprio de; ser dever de»: vide página 77,3 .

a) O livro é do professor.

Liber est magistri.

Esta casa é de meu pai.

Haec domus est patris mei.

b) É dever do professor ensinar.

Est magistri docēre.

É próprio do bom estudante estudar.

Est boni discipüli studēre. 
3 - Esse + dativo de pessoa + dativo de coisa «ser causa de; causar».

Teu filho dá-te as maiores preocupações.

Filius tuus maximis curis tibi est.

Este facto trouxe-nos uma grande desgraça.

Haec rēs nōbis fuit magnō malo.

4 - Esse + in + ablativo de pessoa «existir em... = ter (qualidades morais)》: vide página 77,4 .

Teu irmão teve sangue-frio.

Fuit in fratre tuō animus impauìdus.

Os militares davam provas de valentia.

Virtus in militibus erat.

N.B.:

Recorde a sintaxe dos compostos de ESSE: pp. 149-150. 
E X E R C Í C I O S

1. Vocês têm (= vós tendes) muitos amigos e amigas.

Nós tinhamos uma bela casa.

Príamo (Priămus, $i$ ), rei de Tróia, e sua (= daquele) esposa Hécuba (Hecǔba, ae) tiveram muitos filhos (= filhos e filhas: vd. p. 47)

Eles hão-de ter (= terão) muitas (magnus, a, um) riquezas (pecunia, ae).

Tu tiveras uma enorme (maximus, a, um) quinta (fundus, i).

2. É dever do bom comandante recompensar (praemium tribuěre + dat.) os soldados valentes (strēnuus, $a, u m$ ). 
É dever dos professores castigar (castigāre) os alunos preguiçosos (piger, ra, rum).

3. Esta notícia (nuntia, örum) causou-vos uma grande aflição (luctus, us: masculino).

Os filhos (= filhos e filhas: vd. p. 47) davam-lhes (=a eles $=$ = àqueles) uma grande alegria (gaudium, ii).

A tua felicidade (félič̆tas, ātis) dá-nos uma enorme (summus, $a$, um) satisfação (laetitia, ae).

4. Cícero (Cicèrōōonis) tinha um grande talento (ingenium, ii).

As tropas romanas tiveram a maior coragem (fortis animus) contra (in + acusat.) os inimigos (hostēs, ium). 


\section{GRAUS DOS ADJECTIVOS}

\section{Comparativo:}

a) de igualdade: tam + positivo ... quam.

Ex.:

Frater meus est tam altus quam tuus.

b) de inferioridade: minus + positivo ... quam.

Ex.:

Soror tuă est minus altă quam meă.

c) de superioridade: radical do positivo + -ior (masc. e fem.), -ius (neutro).

Assim:

$$
\begin{array}{ll}
\text { alt } \text {-us } \longrightarrow & \text { altior, altius } \\
\text { liber } \longrightarrow & \text { liberior, liberius } \\
\text { pulcher } \longrightarrow & \text { pulchrior, pulchrius } \\
\text { amans, amant-is } \rightarrow & \text { amantior, amantius } \\
\text { fort-is } \longrightarrow & \text { fortior, fortius } \\
\text { celer } \longrightarrow & \text { celerior, celerius }
\end{array}
$$

DECLINAÇÃO

Singular

Plural

N. -iŏr

-ius

-iōrēs

-iōră

V. $\gg$

$\gg$

》)

》)

Ac. -iōrem

$»$

G. -iōris

》

»

D. -iōri

-iōrum

-iōrǐbus

Ab. -iōre

) 
Exemplos:

Singular

N. altiŏr

V. altiŏr

altius

altius

Ac. altiōrem

altius

G.

altiōris

D.

Ab.

altiōri

altiōre
Plural

altiōrēs

altiōră

altiōrēs

altiōră

altiōres

altiōră

altiōrum

altiōrǐbus

altiōribus
N. amantiŏr

V.

Ac.

G.

D.

Ab.

N. fortiǒr

fortius

V.

Ac.

G.

D.

Ab. amantius

amantius

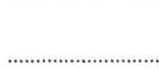


SEGUNDO TERMO DE COMPARAÇÃO

O segundo termo de comparação do comparativo de superioridade exprime-se de dois modos:

1 - no mesmo caso do primeiro termo, precedido de quam:

Frater meus est altior quam tuus.

Soror meă est altior quam tuă.

Mare est altius quam flumen.

2 - em simples ablativo:

Frater meus est altior tuō.

Soror meă est altior tuā.

Mare est altius flumine.

\section{EXERCÍCIOS DE APLICAÇÃO}

$\mathrm{I}$ - O som (sonus, $i$ ) é menos veloz (uēlōx, ōcis) do que a luz (lux, cis).

A luz é mais veloz do que o som.

(ou:

A clemência (clementia, ae) não é menos útil (uť̌lis, e) ao vencedor (uictŏr, öris) do que ao vencido (uictus, i).

O homem piedoso (pius, a, um) reza (ōrāre + acusativo) a Deus tanto na prosperidade como na adversidade (vd. p. 84). 
As tempestades (procella, ae) marítimas (maritimus, a, um) são mais frequentes (creber, bra, brum) no inverno (hiems, hiěmis) do que no verão (aestas, ātis).

Il - Paulus est sapientior quam Iulius.

Antōnius est pigrior Luciō.

Nulla auis uolat altius (comparativo do adv.: vd. pág. 232) aquilā.

Facilius est dicĕre quam facĕre.

Claudius sapientior quam prudentior fuit.

Animi lineamenta sunt pulchriōra quam corporris.

Homērum dilĭgō magis quam Vergilium.

Nihil est morte certius, mortis hōrā nihil incertius. 
Fulgētrum et tonĭtrus simul fiunt: sed fulgētrum prius cernĭtur quam tonı̌trus auditur, quoniam lux sonitu uēlōcior est.

Elephanti, quamquam uirǐbus, magnitudĭne, uēlōitāte praestantiōrēs homǐne, ipsīus conspectum pauent.

Nihil ineptius quam risus ineptus est.

Nihil suauius est quam studēre linguae Latinae.

Domi uita beatior quam militiae est (vd. p. 152, OBSERVAÇÃo).

Paulae aedēs pulchriōrēs sunt quam Iuliae. 
N.B.:

O comparativo de superioridade sem segundo termo de comparação deve traduzir-se por um tanto, bastante, demasiado, particularmente.

Exemplos:

Senectus est loquacior.

Boni libri, tamquam amici boni, pretiōsiōrēs sunt.

Hiěme procellae maritȳmae crebriōrēs sunt.

Aedēs tuae pulchriōrēs sunt.

Cōnsilium tuum utilius est.

Aeminium pulchrius est.

Linguae latinae studēre suauius est. 


\section{Liberi, pulcherrìma matris ởrnamenta}

Cornēlia summō geněre nata (nam Publii Cornēlii Scipiōnis erat filia) habēbat filiōs duōs, Tiberium et Gaium Gracchum.

Ōlim matrōna quaedam, apud eam hospǐta, ōrnamenta sua pulcherrǐma illius saecǔli ei ostendēbat laudans eōrum pretium atque èlegantiam. Cornēlia traxit eam sermōne et, filiis domum ${ }^{1}$ è scholā redĭtis, ad eōs diğ̌tum intendit et «Haec», inquit, «mihi sunt pulcherrĭma ōrnamenta.»

1 Note a ausência da preposição (in).

\section{VOCABULÁRIO}

Cornēlia, ae: Cornélia

Cornēlius, ii: Cornélio

dightus, i: dedo

ēlegantia, ae: delicadeza; bom gosto

Gaius, ii: Gaio

genus, ěris: origem; família

Gracchus, i: Graco

hospirta, ae: hóspede (=hospedada)

intenděre: estender

ad alǐquem diğtum intenděre: apontar para alguém

laudans, antis: que louva; elogiando

matrōna, ae: senhora; dama

natus, a, um; nascido

summō genĕre natus: descen-

dente de uma familia muito ilustre örnamentum, i: adorno

ostenděre: mostrar

pretium, ii: valor

Publius, ii: Públio

pulcherrimus, a, um: muito belo;

$o$ mais belo

redítus, a, um: regressado; tendo regressado

Scipiō, ōnis: Cipião

saecŭlum, i: século ; época

sermō, ōnis: conversa; conversação

summus, a, um: muito elevado; eminente

trahĕre: arrastar

pret. perf. traxi; aliquem sermōne trahĕre: reter alguém a conversar

Tiberius, ii: Tibério 


\section{CONJUGAÇÃO VERBAL}

\section{Futuro perfeito}

$\begin{array}{cl}\text { I - Voz activa } & \\ \text {-ěrō } & \text { fu-ěrō } \\ \text {-ĕris } & \text { fu-ěris } \\ \text {-ěrit } & \text { fu-ěrit } \\ \text {-ĕrĭmus } & \text { fu-ĕrĭmus } \\ \text {-ĕrĭtis } & \text { fu-ěrĭtis } \\ \text {-ěrint } & \text { fu-ěrint }\end{array}$

laudauěrō

dēlēuěrō

monuěrō

rēxěrō 
audiuěrō

II - Voz passiva

\section{Singular}

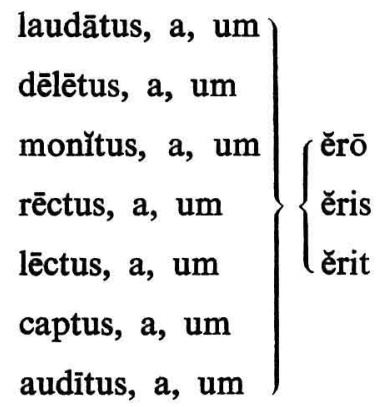

\section{Plural}

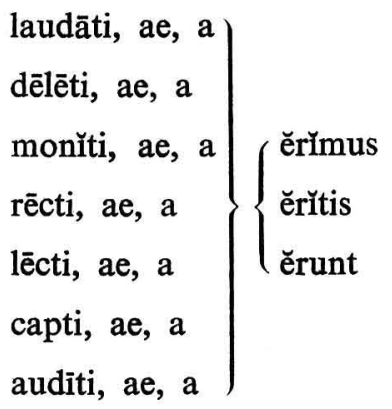




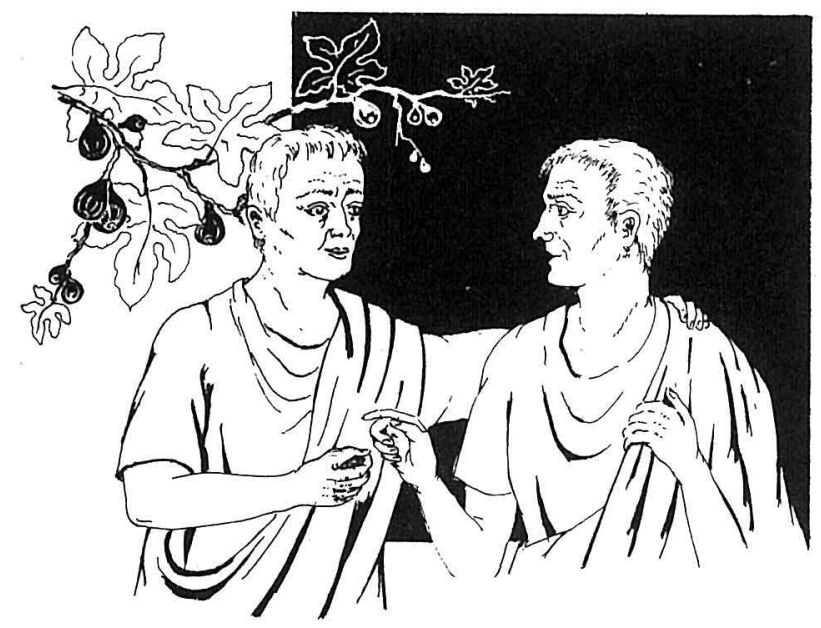

Ficus dē quã sẽ suspendēbant muliěrês

Ōlim uir quidam ${ }^{1}$ ficum in hortō habēbat, dē quā duae eius uxōrēs sē suspendĕrant. Hoc sciēns uicinus ad eum adit et: «ర̄ fortunāte uir», inquit, «qui arbŏrem mirab̧̌lem in hortō habēs ac bene öminātam. Ego autem ${ }^{2}$ uxōrem habeō pessǐmam. Quārē, quaesō, mihi da ${ }^{3}$ surcŭlum ex ficu tuā: nam uolō in ficu meā eum inserěre.»

1 Vd. p. 110, N. B. 2 ego autem 'eu cá'. 3 da, date: imperativo.

\section{VOCABULÁRIO}

adire $[+\mathrm{ad}+$ acusat. $]$ : ir ter ōminātus, a, um: pressagiado (com alguém) arbŏr, ŏris: árvore bene ōminātus: de bom agouro dare: dar ficus, us (feminino): figueira quaesō: por favor sciēns, entis: que sabe; ciente de surcŭlus, i: rebento fortunātus, a, um: afortunado inserĕre: enxertar mirabǔlis, e: admirável mulier, ěris: mulher suspenděre: suspender sē suspenděre: enforcar-se uelle (pres. do ind. uǒlō): querer uicinus, $\mathrm{i}$ : vizinho uxŏr, ōris: mulher; esposa 


\section{CONJUGAÇÃO VERBAL}

\section{Presente do conjuntivo}

Verbo ESSE:

sim
sìs
sit
sīmus
sītis
sint

Voz activa

Voz passiva

laude-m

laude-r

laudē-s

laudē-ris

laude-t

laudē-tur

laudē-mus

laudē-mur

laudē-tis

laudē-mǏni

laude-nt

laude-ntur

mone-a-m

monea-r

mone-ā-s

moneā-ris

mone-a-t

moneā-tur

mone-ā-mus

moneā-mur

mone-ā-tis

moneã-mInni

mone-a-nt

monea-ntur 
capiam

audiam

Pretérito imperfeito do conjuntivo

esse-m
essē-s
esse-t
essē-mus
essē-tis
esse-nt

Voz activa

laudāre-m

laudārē-s

laudāre-t

laudarē-mus

laudarē-tis

laudāre-nt capiar

audiar
Voz passiva

laudāre-r

laudarē-ris

laudarē-tur

laudarē-mur

laudarē-m̌ni

laudare-ntur 
monērem

capĕrem

audīrem

monērer

capèrer

audirer 


\section{BELLVM TRŌIĀNVM AB ŌVŌ NARRĀTVR}

(Continuação da p. 174)

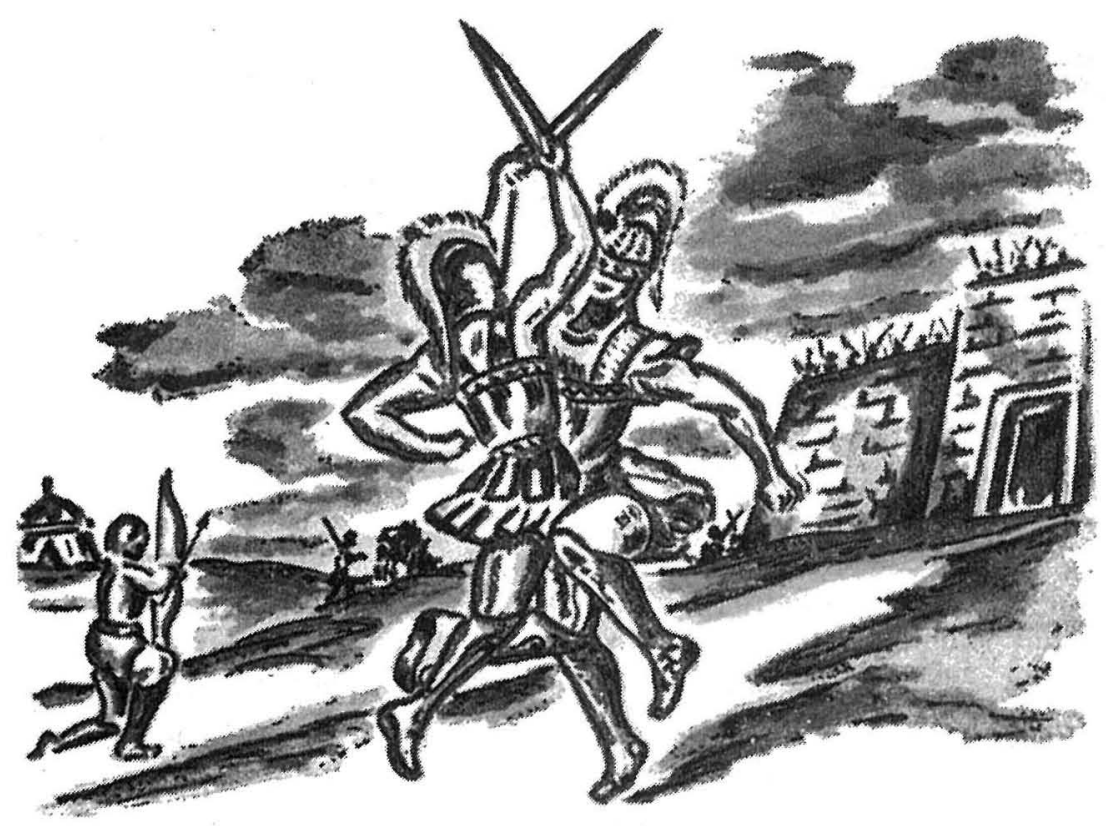

\section{VII - Dẽ Graecōrum dolō}

Agamemnŏne illō ${ }^{1}$ duce, iam per decem annōs ${ }^{2}$ Graeci Trōiam oppugnābant, sed Trōiāni, Veněre Marteque iuuantǐbus, eōrum impětui resistēbant. Tum, tot annis iam ēlapsis et Vlixe hortante, Graecōrum ducēs afflicti bellō iussērunt ${ }^{3}$ milĭtēs materiam ē siluis in castra aduehĕre atque equum facěre immānem, ut 4 uōtum prō fêlīi in patriam redǐtu simulārent. Equō factō, in obscūra eius latēra ascendērunt et auctor ipse doli et nōnnulli êlëcti uiri; relĭqui autem Graeci castra dēsěrunt et nauǔbus in mare dēductis cōnscendunt atque uentō secundō uëla in altum mare dant, tanquam ${ }^{5}$ in Graeciam reuerterentur.

Erat autem in propinquō paruă insǔlă, cui nōmen erat Tenědus. Illuc ẽlapsi occultant sē dēsertō in litŏre. 


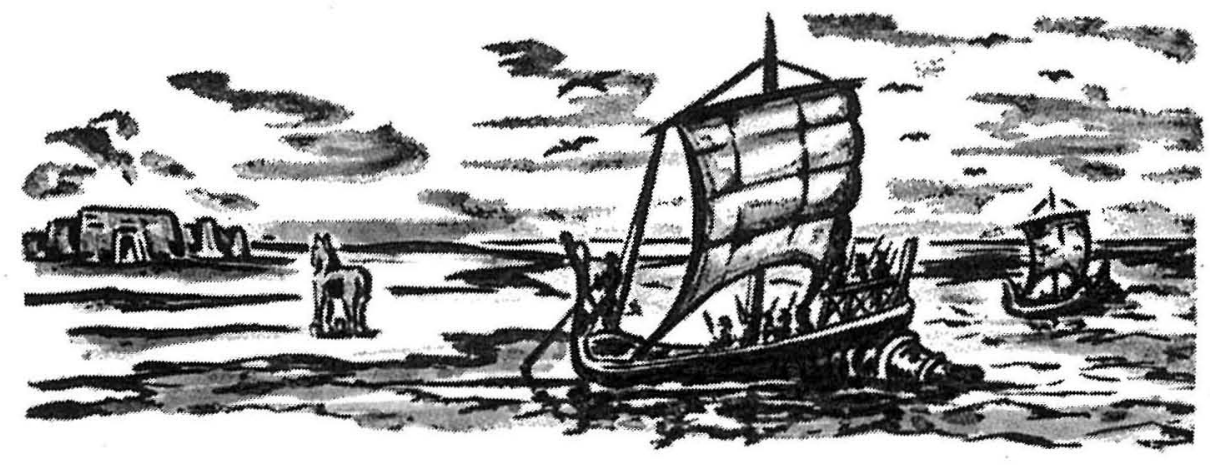

VIII — Dē Trōiānis dēceptis

Primā luce Trōiāni, cum 6 dēserta Graecōrum castra uidērent, putant 7 hostēs in patriam discessisse atque urbem diuturnō cruentōque bellō solūtam esse. Quarē maxĭmā laetitiā affecti sunt et, apertis portis, ex urbe exiērunt, ut ${ }^{8}$ dōnum exitiāle Mineruae oblātum mirarentur. Ităque, dum pars stupet ligneum equum immānem, alii iter faciunt per litus dērelictum. «Hīc 9 crudēlis Achilles», inquiunt 10, «habēbat tentōria; hìc erat statiō nauium; hìc exercĭtus pugnāre solēbant.» Tunc Trōiānus quidam, nōmĭne Thymoetēs, seu per fraudem, seu quia iam fata Trōiae ita uolēbant, primus suādet 11 ut equus intra murōs admittātur et in arce statuātur.

\section{IX - DE Laocoonte}

Erant 12 autem qui suadērent ut dolōsum Graecōrum dōnum uel in mare abicerētur uel cauis eius alui latěbris inspectātis comburerētur. Plebs ambigua distrahĭtur in opposĭta cōnsilia. Tunc Laocoōn sacerdōs magnā turbā sequente celer ē summā arce dēcurrit et procul clamat: «Ō misěri Trōiāni, quae tanta est stultitia ${ }^{13}$ ? An 14 putātis 15 hostēs esse prōfectōs? Aut existimātis 16 ulla Graecōrum muněra carēre fraudǐbus? Aut Graeci clausi in hōc lignō latent; aut haec machĭna structa est contra moenia nostra, ut 17 domōs explōrāret; aut alǐus alǐquis dolus latet. Trōiāni, nōlite 18 fiděre huic equō: quodcumque istud est, metuō Graecōs, etiamdum muněra dant.» 


\section{$X$ - Dē Laocoontis filiōrumque morte}

Deinde Laocoōn magnum taurum ad altaria sacrificat. Ecce autem duo serpentēs immanēs, ab insǔlā Tenědō ēmissi per mare sēdātum, innătant undis et simul accēdunt litus. Omnēs Trōiāni exanimāti fugiunt. Serpentēs autem ad Laocoonta 19 currunt: et primō amplectendō cōnstringunt corpŏra duōrum Laocoontis filiōrum, et dēuǒrant misĕra membra; deinde inuādunt patrem ipsum uenientem in auxilium, spirisque grandǐbus inuoluunt. Ille simul cōnātur maň̆bus dirumpěre nexus; simul anı̆mam agēns clamōrēs horrendōs ēmittit. Laocoonte filiisque mortuis, gemĭni anguēs serpendō fugiunt ad summa templa et abeunt in aedem 20 saeuae Mineruae et occultant sē sub pedřbus simulacri.

\section{(Continua.)}

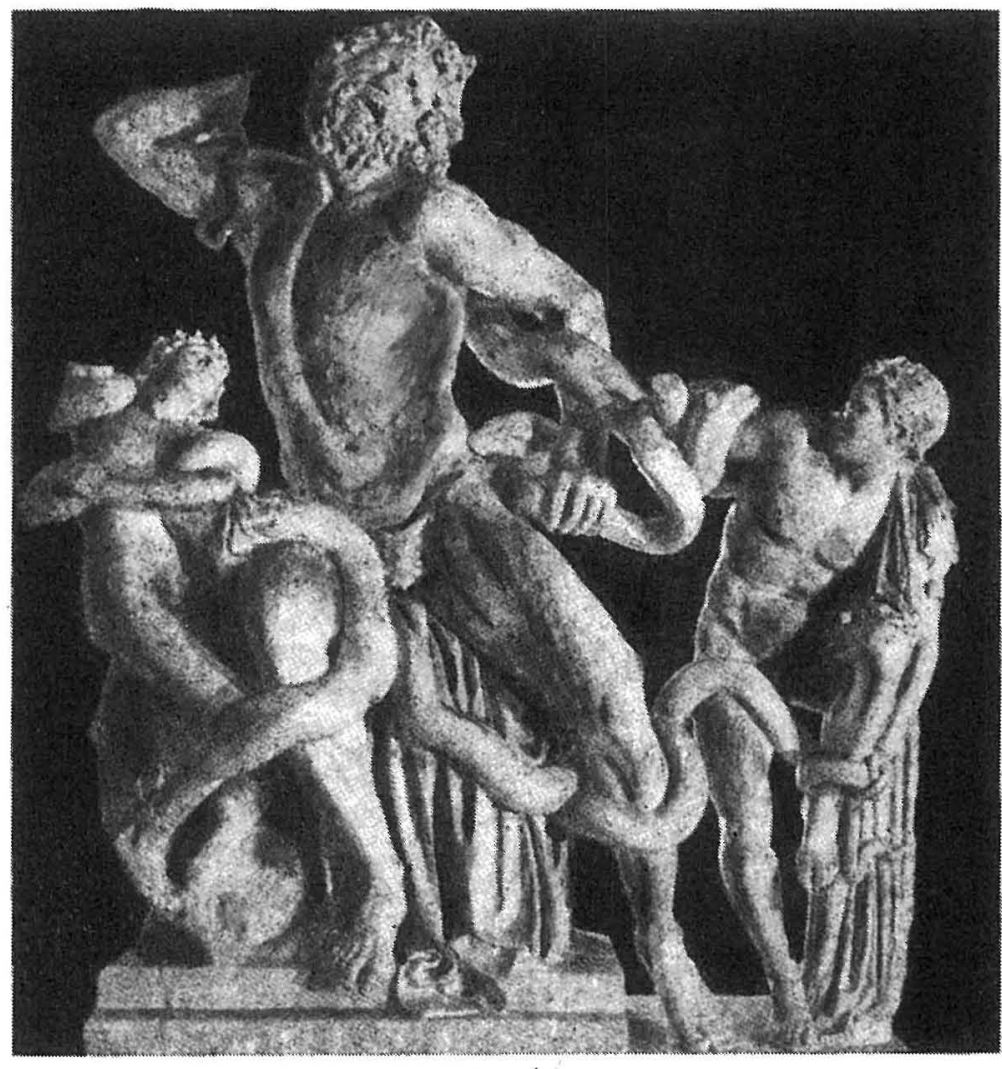

MUSEU Do VATICANo. Grupo de Laocoonte 


\section{NOTAS}

1 O pronome ille é frequentemente usado, como aqui, com o significado de célebre, famoso, ilustre, etc. Sobre o ablativo absoluto, vd. p. 162 sqq.

2 per decem annōs, 'há (ou havia) dez anos': o complemento circunstancial de tempo durante o qual exprime-se geralmente em acusativo sem ou com a preposição per.

3 O verbo iubēre 'mandar, ordenar' constrói-se com orạ̧ão infinitiva (sujeito - militès - em acusativo, e predicado - aduehëre; facĕre - no infinitivo), que em português se traduz por uma integrante. Vd. cap. I, nota 3 (p. 175).

$4 u t$... simulärent: oração final (note o conjuntivo).

5 tanquam... reuerterentur 'como se regressassem': note o conjuntivo. Certos verbos, como reuertor, ěris, reuerti, reuersus sum, só têm forma passiva, embora com significado activo (verbos depoentes).

6 cum... uidērent: oração causal (note o conjuntivo).

7 O verbo putāre tem uma construção idêntica à de iubēre: vd. supra, nota 3. $\mathrm{O}$ infinitivo do perfeito discessisse deverá, por isso, traduzir-se por que se retiraram. Do mesmo modo, solūtam esse (inf. perf. passivo) 'que se libertou; que estava liberta'.

8 ut... mirarentur: vd. supra, nota 4, e reuertor, nota 5.

9 Não confundir o advérbio de lugar hic 'aqui' com o demonstrativo hic 'este'.

10 Recorde-se que inquit 'diz (ele)' e inquiunt 'dizem (eles)' só se usam intercalados no discurso directo.

11 suãdet ut... admittātnr... statuātur: o verbo suadēe 'aconselhar; exortar; persuadir' tanto se pode construir com uma oração infinitiva como com uma oração integrante de $u t+$ conjuntivo.

12 Erant... qui suadẽreut 'havia quem fosse de opinião': note o conjuntivo, regular depois das expressões sunt qui 'há quem', non dēsunt qui 'não falta quem', inueniuntur qui 'encontra-se quem' (oração relativa de conjuntivo). Para a construção de suadēre, vd. supra, nota 11 .

13 Traduza como se estivesse: quae tanta stultitia est uestra?

$14 \mathrm{Vd}$. orações interrogativas directas (p. 69 sqq.).

15 Vd. supra, nota 7.

16 O verbo existimāre 'pensar; julgar' tem uma construção idêntica à dos verbos iubēre (nota 3) e putäre (nota 7): ulla... munëra carēre... 'que há alguma dádiva que não contenha...'

17 Oração final: vd. supra, nota 4.

18 nolite fidère 'não confieis; não confiem': o imperativo negativo pode exprimir-se, como aqui, com o imperativo do presente de nolle 'não querer' (noli, nolite), seguido de infinitivo. Assim, por exemplo, nōli amāre 'não ames', nöltte amāre 'não amem'; nơli exire 'não saias', nôlite exire 'não saiam', etc.

19 O vocábulo Laocoōn, de origem grega, apresenta no acusativo (do sing.) uma desinência em -ă (= lat. -ěm), própria daquela língua: vd. cap. VI, nota 17 (p. 175: Agamemnöna).

20 Vd. p. 114, 3. 


\section{VOCABULÁRIO}

abicěre: lançar

abire: dirigir-se

3. ${ }^{a}$ p. pl. pres. ind. abeunt

accēdere [+ acusat.]: aproximar-se de

admittěre: impelir para; levar

aduehĕre: transportar; trazer

afficĕre: prover; na pass. ser tomado

part. pass. affectus, a, um

afflictus, a, um: abatido; desesperado

agĕre: conduzir; fazer sair

anǏmam agĕre: entrar em agonia; exalar o último suspiro alĭquis ou alĩqui, alĭqua, alĭquid ou alĭquod: algum; alguém alius aliqquis: algum outro altaria, ium: altar (onde se fazem sacrificios)

aluus, i: ventre; bojo

ambiguus, a, um; incerto; indeciso amplecti (depoente): abraçar amplectendō corpǒra: abraçando ou envolvendo os corpos anguis, is: serpente; cobra apertus, a, um: aberto arx, arcis: cidadela (vd. p. 114, 2) auctor, ōis: autor; instigador aut... aut...: ou... ou...

carēre [+ablat.]: estar isento de cauus, i: côncavo

celer, ěris, ĕre: lesto; rápido

clamor, ōris: grito

clausus, a, um: encerrado

comburĕre: queimar inteiramente; destruir pelo fogo cōnāri: tentar; esforçar-se por

cōnscenděre: embarcar

cōnsilium, ii: opinião

cōnstringěre: apertar

cruentus, a, um: sangrento

dăre: dar

uêla dăre: navegar

dēceptus, a, um: enganado

dēcurrěre: descer em corrida

dēductus, a, um: lançado

dērelictus, a, um: abandonado

dēserěre: abandonar

dēuorāre: devorar

dirumpĕre: quebrar; romper; desfazer

discēdĕre: retirar-se

distrahěre: dividir; na pass. dividir-se

diuturnus, a, um: que dura há muito tempo; longo

dolōsus, a, um: enganador; traiçoeiro

dolus, i; ardil

dōnum, i: dádiva; presente

ecce: eis; eis que

ēlapsus, a, um: decorrido; que se retirou

èlēctus, a, um: escolhido

ēmissus, a, um: enviado

ēmittěre: lançar; soltar

equus, i: cavalo

etiam: ainda

etiamdum: mesmo quando

exanimātus, a, um: amedrontado;

espavorido

exire: sair

pret. perf. ind. exii 
exitiālis, e: funesto; fatal

explōrāre: espiar

fatum, i: fado; destino

fiděre [ + dat.]: confiar em

fraus, fraudis: engano; cilada; má fé

geminnus, a, um: gémeo; que forma um par

gemĭni anguēs: ambas as serpentes

grandis, e: de grandes proporções; forte

hortans, antis: que instiga

hostēs, ium: inimigos

illuc: para lá

immānis, e: enorme; gigantesco impětus, us: ataque

innătāre [+ dat.]: nadar sobre ou

à superficie de

inspectātus, a, um: inspecionado inuaděre [+ acusat.]: lançar-se sobre; atacar

inuoluěre: envolver

iter, itiněris (neutro): caminho iter facěre: percorrer; caminhar iuuans, antis: que ajuda

laetitia, ae: alegria

Laocoōn, ontis: Laocoonte

latěbra, ae: esconderijo

latēre: esconder-se; estar escondido

latus, ěris: flanco

ligneus, a, um: de madeira

lignum, i: madeira; madeiro

litus, orris: litoral; praia

lux, lucis: luz

primā luce: ao despontar do dia; ao alvorecer

materia, ae: madeira

metuěre: recear; temer mirāri (depoente): admirar; contemplar

miser, ěra, ěrum: infeliz; pobre moenia, ium: muralhas (de cidade)

mors, mortis: morte

munus, ěris: dádiva; presente

nexus, us: nó

nonnullus, a, um: algum

oblātus, a, um: oferecido

occultāre: ocultar; esconder

oppositus, a, um: oposto; contrário

oppugnāre: cercar; atacar

pars, partis: (uma) parte

paruus, a, um: pequeno

plebs, is: plebe; multidão; popu-

lacho

porta, ae: porta (de cidade)

primō: primeiramente; primeiro primus, a, um: (aquele que é o) primeiro

procul: de longe

prōfectus, a, um: que se retirou propinquus, a, um: próximo

in propinquō: nas proximidades

putāre: pensar; julgar

quicumque, quaecumque, quod-

cumque: todo aquele que; quem

quer que; seja quem for

quodcumque istud est: seja isto

$o$ que for

redïtus, us: regresso

relĭquus, a, um: restante

resistěre: resistir

sacerdōs, ōtis: sacerdote

sacrificāre: imolar

saeuus, a, um: cruel

sēdātus, a, um: calmo 
sequēns, entis: que segue

magnā turbā sequente: seguido de grande multidão

serpēns, entis (masculino): serpente serpěre: rastejar; serpentear serpendō: a serpentear seu... seu...: quer... quer... simul: ao mesmo tempo simul... simul...: ao mesmo tempo... e...

simulacrum, i: imagem; estátua sub pedřbus simulacri: debaixo dos pés da estátua (subent. da deusa Minerva)

simulāre: simular; fingir

solēre: costumar

spira, ae: espiral; anel (das serpentes)

statiō, ōnis: ancoradouro statuěre: instalar

struĕre: construir

part. pass. structus, $a, u m$ stupēre: aamırar

summus, a, um: o mais alto; muito elevado

ad summa templa: para o alto dos templos

Tenĕdus, i: Ténedo

tentōrium, ii: tenda (de campanha)

Thymoetēs, ae: Timeta

tot [indeclinável]: tantos

tunc: então; foi então que

turba, ae: multidão

uel... uel...: ou... ou...

uelle: querer

uēlum, i: vela (de barco)

ueniēns, entis: que vem ou vai uidēre: ver

ullus, a, um: algum

uolēbant: $v d$. uelle

uōtum, i: voto; promessa; oferenda

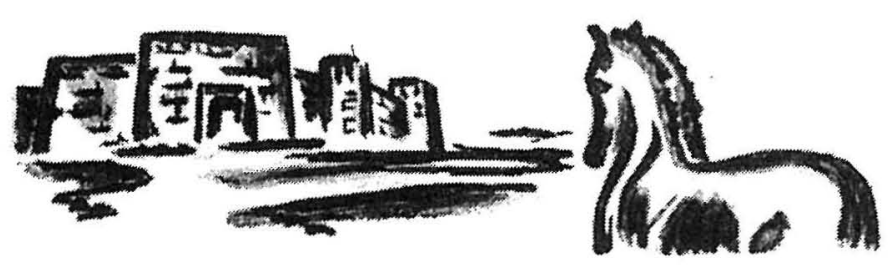




\section{CONJUGAÇÃO VERBAL}

\section{Pretérito perfeito do conjuntivo}

\section{Verbo ESSE}

fu-ĕrim

fu-ĕris

fu-ěrit

$1-V o z$ activa

laudau-ĕrim

laudau-ĕris

laudau-ěrit fu-erĭmus

fu-erritis

fu-ěrint

laudau-erimus

laudau-eritis

laudau-ěrint dēlēuěrim

monuěrim 
lēgèrim

cēperrim

II - Voz passiva rēxěrim

audiuĕrim

Particípio passado + pres. do conj. de ESSE

Vd. p. 192, ao fundo.

\section{CONJUGAÇÃO}

laudātus, a, um sim

$\gg \gg$ sis

$\gg \quad \gg \quad$ sit

laudāti, ae, a simus

\》 $\gg$ sitis

$\gg \quad$ \ $\quad$ sint 
Pretérito mais-que-perfeito do conjuntivo

\section{Verbo ESSE:}

fu-issem

fu-issēs

fu-isset

I - Voz activa

laudau-issem

laudau-issēs

laudau-isset fu-issēmus

fu-issētis

fu-issent laudau-issēmus

laudau-issētis

laudau-issent dēlēuissem

monuissem 


\section{II - Voz passiva}

$$
\begin{aligned}
& \text { Participio passado }+ \text { imperf. do conj. de ESSE } \\
& \text { Vd. p. 192, ao fundo. }
\end{aligned}
$$

CONJUGAÇÃO

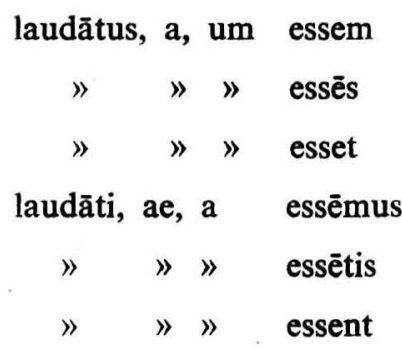




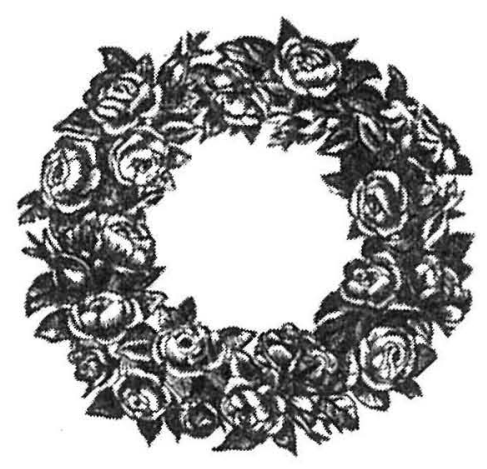

Dẽ Arriā, matre animōsā

Aegrōtābat marītus cuiusdam muliěris, nōmǐne Arriae; aegrōtābat et 1 filius, uterque mortifěrēe, ut uidēbātur. Filius dēcessit, eximiā pulchritudĭne et pari uerēcundiā 2 parentum. Huic mater ita ${ }^{3}$ funěra parāuit, ita 3 duxit exsequias, ut ignōrāret marītus. Quin immō, quotiēns cubicŭlum eius intrāret ${ }^{4}$, uiuěre filium 5 atque etiam commodiōrem esse simulābat; ac persaepe interroganti 6 quid 7 agĕret puer, respondēbat: «Bene quiēuit, libenter cibum sumpsit.» Deinde, cum ${ }^{8}$ diu cohibǐtae lacrĭmae uincěrent prōrumperentque, ēgrediēbātur. Tunc sē dolōri dabat; satiātā 9 , siccis ocǔlis, composítō uultu redỉbat, tanquam orbitātem foris reliquisset.

1 et: também.

2 eximiā pulchritudĭne... pari uerẻcundiã: ablativos de qualidade: [jovem] de extraordinária beleza [e] igual respeito [para com os pais].

3 ita... ut [+ conjunt.]: de tal modo ... que (oração consecutiva).

4 Conjuntivo de repetição.

5 uiuĕre filium ... esse commodiōrem: que o filho estava vivo ... que estava bem melhor (orações infinitivas dependentes de simuläre. Vd. p. 200, nn. 3 e 7); sobre o comparativo, vd. p. $189, N$. $B$.

6 interroganti [subent. maritō]: [ao marido] que perguntava. Traduza por: Perguntando-lhe ele, ...

7 quid agĕret: como passava (oração interrogativa indirecta: note o conjuntivo).

8 cum [+ conjunt.]: oração causal.

9 satiātã [subent. dolōre]: ablativo absoluto. 


\section{VOCABULÁRIO}

aegrōtāre: estar ou encontrar-se doente

animōsus, a, um: corajoso

Arria, ae: Árria

bene: bem

cibus, i: alimento

cohibrtus, a, um: reprimido

commŏdus, a, um: conveniente

composĭtus, a, um: calmo

dăre: dar

sē dăre: entregar-se

dēcēděre: ir-se embora; acabar por morrer

deinde: depois; seguidamente

diu: durante muito tempo

dolor, ōris: dor

ducěre: conduzir

pret. perf. ind. duxi

ēgrědi (v. depoente): sair;

retirar-se

etiam: até

eximius, a, um: extraordinário

exsequiae, ārum: enterro

foris: fora; lá fora

funus, ěris: cerimónia fúnebre; funeral

ignōrāre: ignorar ; nada saber

libenter: de boa vontade

libenter cibum suměre: comer com apetite maritus, i: marido

mortifěrē: mortalmente; em perigo de vida

orbĭtas, ātis: privação de filhos; perda de um filho

par, paris: igual

paräre: preparar

prōrumpĕre: irromper; saltar (dos olhos)

pulchritūdō, Ǐnis: beleza

quiēscěre: repousar; descansar

quin: ainda mais

quin immō: $e$ o que é mais

quotiēns: todas as vezes que;

sempre que

redire: voltar; regressar

relinquĕre: abandonar; deixar

pret. perf. ind. reliqui

satiātus, a, um: acalmado

siccus, a, um: seco; enxuto

simulāre: fingir

suměre: tomar

pret. perf. ind. sumpsi

tanquam: como se

tunc: então

uerēcundia, ae: recato; respeito

uincěre: vencer; ser mais forte

uterque, utrăque, utrumque: um

e outro; ambos

uultus, us: rosto 
Imperativo presente

Voz activa

Voz passiva

ès

este

laudā

laudāte

laudāre

laudāmìni

dēlē

dēlēre

dēlēte

dělēminni

lěge

lěgěre

lěgite

lěgĭmini

cape

capěre

capite

capìminini

audi

audire

audite

audimini

Infinitivo presente

Voz activa

Voz passiva

esse

laudāre

laudāri

$\left\{\begin{array}{l}\text { dēlēre } \\ \text { monēre }\end{array}\right.$

(dēlēri

monēri

$\left\{\begin{array}{l}\text { lĕgĕre } \\ \text { capĕre }\end{array}\right.$

flègi

capi

audire

audiri 


\section{Infinitivo perfeito}

Voz activa

Voz passiva

fu-isse

laudauisse

$\left.\begin{array}{l}\text { laudātum, am, um } \\ \text { laudātōs, ās, ă }\end{array}\right\}$ esse

$\left\{\begin{array}{l}\text { dēlēuisse } \\ \text { monuisse }\end{array}\right.$

$\left.\begin{array}{l}\text { dēlētum, am, um } \\ \text { dēlētōs, as, a }\end{array}\right\}$ esse

$\left.\begin{array}{l}\text { monĭtum, am, um } \\ \text { monĭtōs, as, a }\end{array}\right\}$ esse

$\left\{\begin{array}{l}\text { lēgisse } \\ \text { cēpisse }\end{array}\right.$

$\left.\begin{array}{l}\text { lēctum, am, um } \\ \text { lēctōs, as, a }\end{array}\right\}$ esse

$\left.\begin{array}{l}\text { captum, am, um } \\ \text { captōs, as, a }\end{array}\right\}$ esse

audiuisse

$\left.\begin{array}{l}\text { audītum, am, um } \\ \text { auditōs, as, a }\end{array}\right\}$ esse

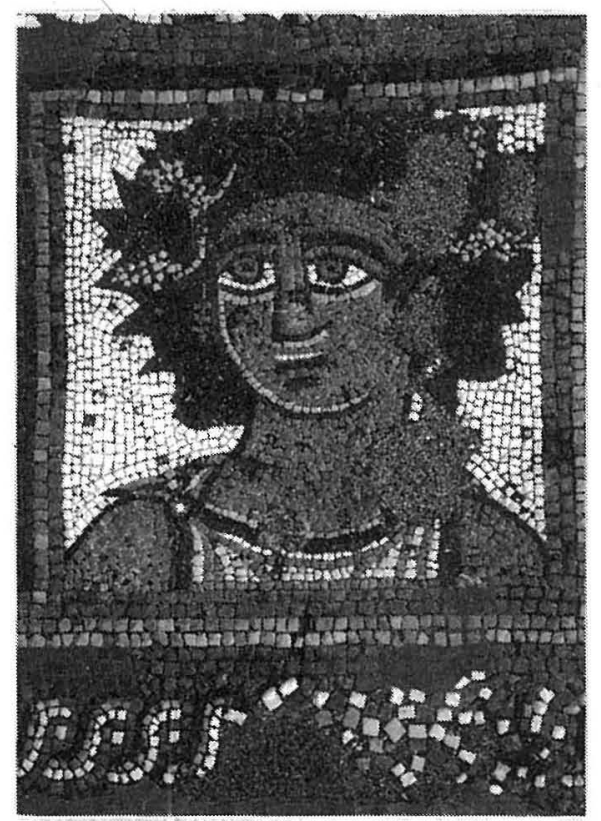

CONÍMBRIGA - O Outono 


\section{ORAÇÔES INFINITIVAS}

Denominam-se infinitivas as oraçðes que têm o predicado no infinito e o sujeito (e o nome predicativo do sujeito, se o houver) em acusativo.

Estas orações são pedidas pelos verbos:

1. declarativos ou locuções declarativas;

2. sensitivos;

3. volitivos;

como, por exemplo:

1. dicō (is, ère, dixi, dictum) 'eu digo' affirmō (as, āre, äui, ātum) 'eu afirmo' negō (as, āre, āui, ātum) 'eu digo que não' scribō (is, ěre, scripsi, scriptum) 'eu escrevo' narrō (as, äre, āui, ātum) 'eu narro; conto' fama est 'é fama; conta-se' fertur 'diz-se' e ferunt 'dizem'

2. sentiō (is, ire, sēnsi, sēnsum) 'eu sinto; percebo; penso; sei bem; bem vejo'

uideō (ēs, ère, uidi, uisum) 'eu vejo' audiō (is, ire, tui, ttum) 'eu ouço dizer' acč̄piō (is, ère, cēpi, ceptum) 'eu ouço dizer' cōgūtōo (as, āre, āui, ātum) 'eu penso' ducō (is, ère, duxi, ductum) 'eu considero' crēdō (is, ère, dìdi, dìtum) 'eu confio; creio; suponho' existimō (as, āre, āui, ātum) 'eu penso; sou de opinião' cognōscō (is, ère, gnōui, gnitum) 'eu tenho conhecimento' faciö (is, ère, fëci, factum) 'eu suponho' intellĕgö (is, ère, lēxi, lēctum) 'eu apercebo-me' sciō (is, ire, sciui, scitum) 'eu sei' nesció (is, tre, tui ou ii, ttum) 'eu não sei', 'ignoro' ignōrō (as, āre, āui, ātum) 'eu ignoro' 
gaudē̄ (ēs, ēre, gauisus sum) 1 'eu alegro-me; muito folgo' doleō (ès, ère, ui, ̌̌tum) 'eu lamento'

3. uolō 2 (uis, uelle, uolui) 'eu quero' nōlō (nōn uis, nōlle, nōlui) 'eu não quero' malō (mauis, malle, malui) 'eu prefiro' cupiō (is, ĕre, iui ou ii, itum) 'eu desejo vivamente; anseio por' studeō (ès, ère, ui) 3 'eu desejo; esforço-me por que'

EXEMPLOS :

I. Antōnius est bonus.

António é bom.

$\left.\begin{array}{ll}\text { 1. } & \text { Negō } \\ \text { 2. } & \text { Audīmus } \\ \text { 3. } & \text { Cupiunt }\end{array}\right\}$ Antōnium esse bonum.

1. Eu digo que António não é bom.

2. Ouvimos dizer que António é bom.

3. Eles desejam vivamente que António seja bom.

Agricŏla agrum arat.

$O$ agricultor lavra o campo.

$\left.\begin{array}{ll}\text { 1. } & \text { Dicō } \\ \text { 2. } & \text { Sentiō } \\ \text { 3. } & \text { Volō }\end{array}\right\}$ agricŏlam agrum arāre.

1. Eu digo que o agricultor lavra (ou: está a lavrar) o campo.

2. Eu bem vejo que o agricultor lavra (ou: está a lavrar) o campo.

3. Eu quero que o agricultor lavre o campo.

1 Este verbo, activo no sistema do presente, tem forma passiva nos tempos do perfeito (verbo semidepoente).

2 Para a conjugação deste verbo, bem como a dos dois verbos seguintes, vd. p. 270 sqq.

3 Note que este verbo não tem supino. 
Agricŏla agrum arāuit.

O agricultor lavrou o campo.

1. Affirmō

2. Videō agricŏlam agrum arauisse.

3. Studeō

1. Eu asseguro que o agricultor lavrou o campo.

2. Eu vejo que o agricultor lavrou o campo.

3. Eu desejo que o agricultor tenha lavrado o campo.

II. Ager ab agricŏlā arātur.

O campo é (ou: está a ser) lavrado pelo agricultor.

1. Dicunt

2. Cōğtō agrum ab agricŏlā arāri.

3. Nōlō

1. Dizem que o campo está a ser lavrado pelo agricultor.

2. Penso que o campo está a ser lavrado pelo agricultor.

3. Não pretendo que o campo seja lavrado pelo agricultor.

Ager ab agricŏlā arātus est.

O campo foi lavrado pelo agricultor.

$\left.\begin{array}{ll}\text { 1. } & \text { Fertur } \\ \text { 2. } & \text { Scimus } \\ \text { 3. } & \text { Malō }\end{array}\right\}$ agrum ab agricōlā aratum esse.

1. Diz-se que o campo foi lavrado pelo agricultor.

2. Sabemos que o campo foi lavrado pelo agricultor.

3. Antes quero que o campo tenha sido lavrado pelo agricultor. 
E X E R C Í C I O S :

I. Creio que Deus existe.

Só hoje (Hodiē tantum) vocês tiveram (= vós tivestes) conhecimento de que eu estava doente (aegrōtāre).

Dizem-me que Cláudia esteve doente.

O poeta Virgílio (Vergilius, ii) conta que Gregos e Troianos lutaram (pugnāre) durante dez anos (=acusativo de duração) junto de Tróia.

Suponho que o professor louvou os bons alunos.

Ouvimos dizer que Lúcio está em Roma (= locativo), em casa do [seu] amigo António.

Sei que tu estiveste (= permaneceste: manēre; pret. perf. ind. mansi) três dias (= acusativo de duração) em Lisboa. 
Eles pensam que nós estamos a ler $(=$ lemos $)$ estes livros.

Bem sabemos que ele (= aquele) escreveu (scriberre: pret. perf. ind. scripsi) uma carta aos (ad+ acusat.) pais.

Muito folgo que vocês estejam (= vós estejais) bem de saúde (estar bem de saúde: ualëre).

Desejamos sinceramente que tu estudes (studère).

Prefiro que vocês se calem (= vos caleis: tacēre).

II. A história narra que a cidade [de] Tróia foi tomada e incendiada (incendere: supino incensum) pelos Gregos.

Em Tito Lívio, famoso (praeclārus, $a$, um) historiador (rērum scriptor, öris) romano, diz-se que Roma foi fundada (condère: supino condítum) por Rómulo (Rōmũlus, $i$ ), descendente de (oriundus, $a, u m+a b+$ ablat.) Eneias. 
Em Cícero (Cícěrō, ōnis), no discurso (ōrātiōo, ōnis) intitulado (=que se intitula = que é intitulado: vd. p. 81) Defesa do poeta Árquias (vd. p. 12), lê-se que todos os ramos do saber (ars, artis: feminino), que dizem respeito à (pertinēre $+a d+$ acusat.) cultura humana (humanĭtas, àtis), têm (habēre) um vínculo (uincülum; i) comum (commūnis, e) e estão ligados (v. passiva de continēre) entre si (inter + acusat.) por um certo (vd. p. 107, c)) grau de parentesco (cognatiō, ōnis).

IMPORTANTE :

I. O verbo iubeō, ès, ère, iussi, iussum 'mandar; ordenar; dar ordem para que' constrói-se com:

a) infinito activo, se vem expressa a pessoa a quem se ordena (esta vai para acusativo, sujeito da oração infinitiva);

b) infinito passivo, se não vem expressa a pessoa a quem se dá a ordem.

EXEMPLOS:

a) Iubeō te littěras ad patrem tuum scriběre.

Ordeno-te que escrevas uma carta a teu pai.

b) Iubeo littěras scribi.

Dou ordem para que se escreva a carta (= para que a carta seja escrita).

a) Iubet $m \bar{e}$ pecuniam tibi dare.

Ele ordena-me que te entregue o dinheiro.

b) Iubet pecuniam tibi dari.

Ele dá ordem para que se te entregue o dinheiro (= para que o dinheiro te seja entregue). 
a) César (Caesar, ăris) ordenou aos soldados (miles, ǔtis) que assentassem arraiais (castra pōnère) junto do rio (flumen, inis).

b) César mandou assentar arraiais junto do rio.

a) Vocês ordenaram ao timoneiro (gubernātor, ōris) que navegasse (nauigāre) para a (=em direcção à) ilha.

b) Vocês deram ordem para navegar (= se navegar) para a ilha.

a) Os deuses ordenaram a Príamo que fizesse sair (= expulsasse: expellerre) Páris da cidade [de] Tróia.

b) Os deuses mandaram expulsar (=que se expulsasse) Páris da cidade [de] Tróia. 
II. Note a expressão certiōrem facěre alǐquem ( + oração infinitiva) 'informar alguém de que'.

EXEMPLOS:

Certior factus sum amicōs nostrōs Rōmae manēre.

Fui informado de que os nossos amigos se encontram em Roma.

Certiōrem faciō tē aegrōtāre patrem tuum.

Informo-te de que o teu pai está doente.

Lucius nōs certiōrēs fêcit sē Rōmae esse.

Lúcio informou-nos de que se encontrava em Roma.

EXERCÍCIOS:

O mensageiro (nuntius, ii) informou os comandantes (dux, ducis) de que os inimigos (hostēs, ium) tinham acampado (castra pōnère; pret. perf. ind. posui) não longe (nōn longē $a b+$ ablat.) da cidade.

Fomos informados de que teus pais (parentēs, ium) chegam (aduenire) hoje (hodiē) na companhia de (unā cum + ablat.) teus irmãos (frater, ris) e irmãs (soror, orris). 


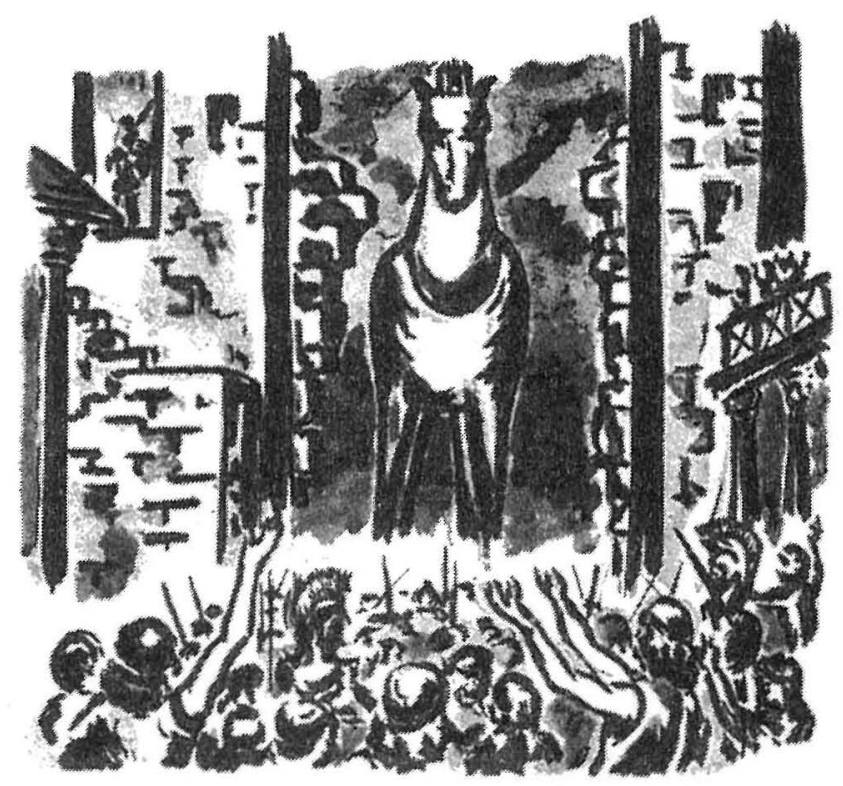

XI - Equus Trōiam ${ }^{1}$ inueh̆̌tur

Trōiāni tandem statuunt 2 ut equus in urbem inuehātur atque in arce locētur. Omnēs praepārant sē ad opus: dum alii murōs ēuertunt (nam equus immānis per portam transire nōn potĕrat), alii pedǐbus equi rotas suppōnunt et collō funēs ē stupā iniciunt. Ecce fatālis machǐna prōgredĭtur plēna armātis et minans in mediam urbem inducǐtur; puěri puellaeque sacra carmǐna canunt. Cum autem murōs intrābat ${ }^{3}$, quater restîtit in ipsō adǐtu portae et quater arma Graecōrum in eius aluō latentium strepřtum ēdidērunt. Vrgent tamen Trōiāni improuǐdi et insaniā occaecāti, et equum funestum in sacrā arce locant. 


\section{XII - Tröiae ${ }^{4}$ tandem Graeci!}

Misěri Trōiāni, nescientẽs 5 diem illum futūrum esse extrēmum, templa deōrum festīuis ramis ōrnant.

Intěrim nox in Oceănum cadit, tegēns magnis umbris et terram et caelum et fraudēs Graecōrum. Trōiāni sparsi per urbem siluē-

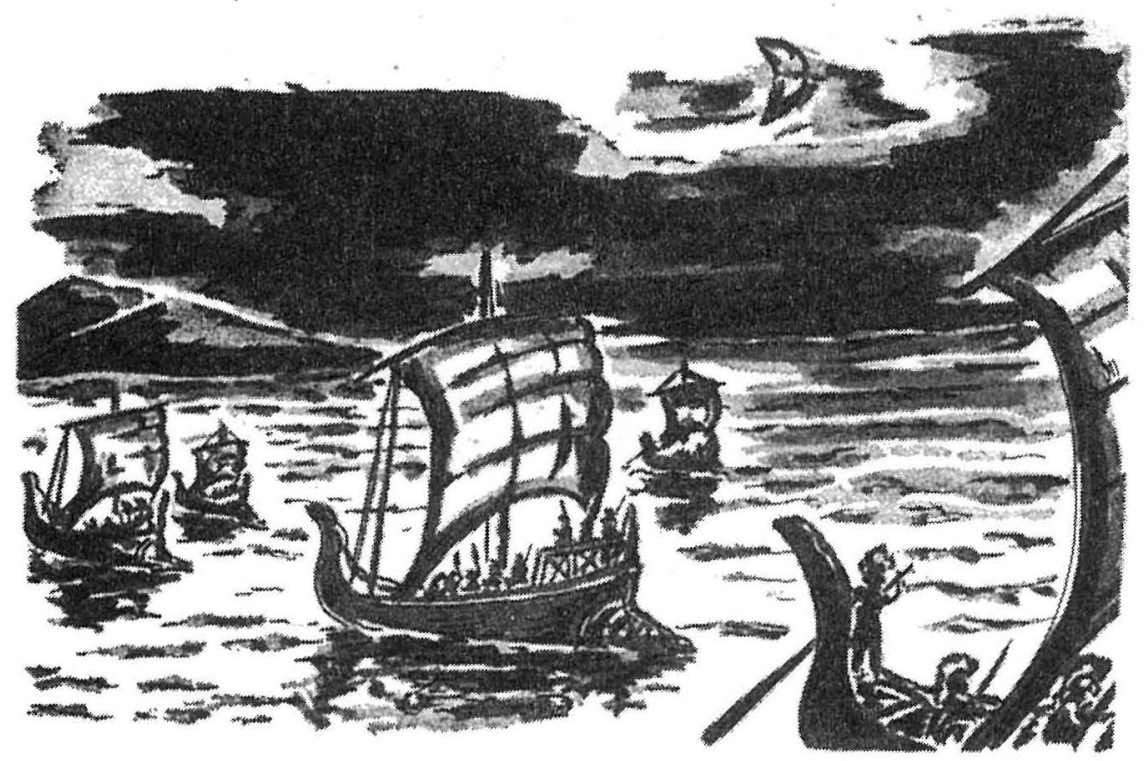

runt: somnus lassa membra tenet. Et, dum silente nocte Graecōrum exerčrtus è Tenědō insǔlā prōfectus ad Trōiāna litŏra accēdit, ii, qui equi in aluō claudēbantur, hilărēs dēscendunt. Aggrediuntur urbem uinō ac somnō impeditam et, excubitōrǐbus occīis et apertis portis, admittunt omnēs sociōs ē nauǐbus ēgressōs. Sic coniunctae Agamemnŏnis Vlixisque turmae exscidium Tröiae parant.

\section{XIII - Aenēae somnium}

Tempus erat quō primus somnus fessis hominirbus subit. Ecce in somnis Trōiānus Hector, qui ab Achille interfectus erat, tristissī- 


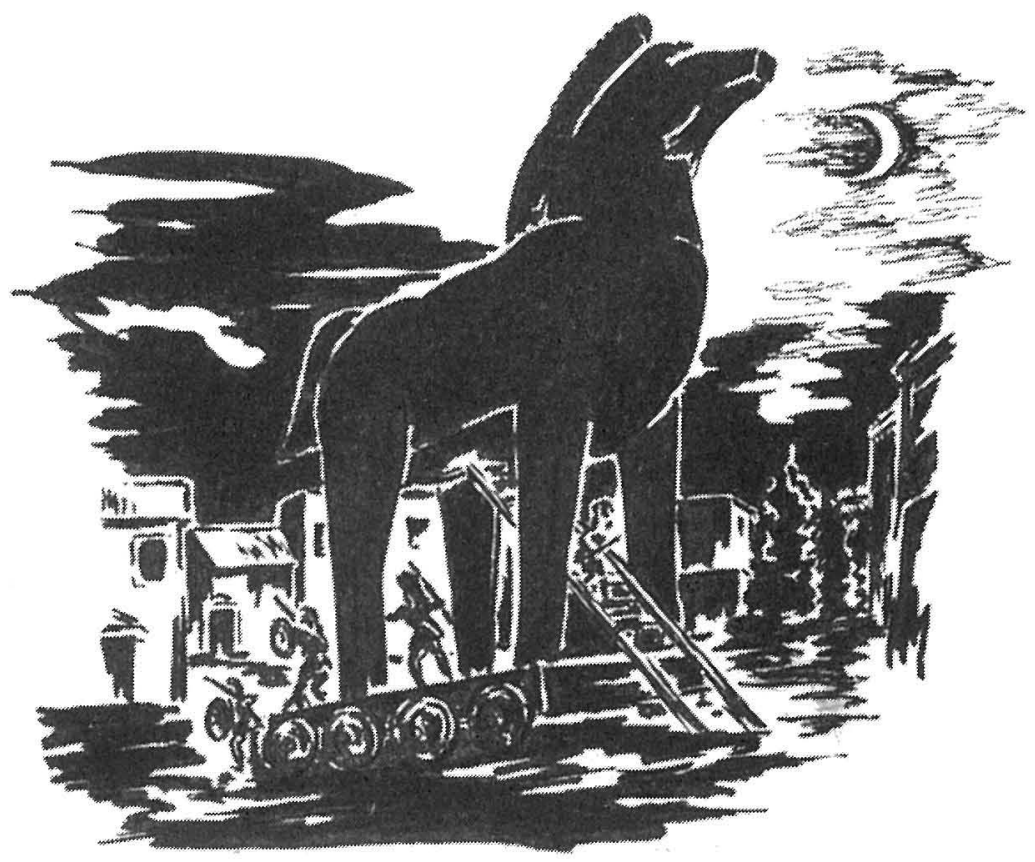

mus uisus est Aeneae et aegrē trahēns gemĭtus ex intĭmō pectŏre: «Heu!'fuge, fuge, fili 6 Veněris», inquit: «hostēs tenent urbem atque incenduñt. Trōia tibi commmittit sacra sua et Penātēs: accīpe hōs casuum tūōrum sociōs ${ }^{7}$; illis quaere urbem, quam tandem pererrātō mari condēs magnam.» Sic locutus est. Intěrim urbs turbātur uariō ululātu; magis magisque armōrum sonus auditur. Aenēas ē somnō excitātur et arma summēns attonĭtus cum nōnnullis sociis in arcem conuǒlat.

\section{XIV - Trōiae suprēma diēs 8}

Graeci autem in urbe inflammātā iam rēgnābant. Multa exanimia corpŏra et per uias et per domōs et per templa passim funduntur. Saeui Graeci irruentēs omnia uastant atque ēuertunt. Tamen Aenēas, 
mortem praefĕrens fugae, acrĭter pugnat; sed, Priămō rëge Pyrrhi 9 manu interfectō et uastāta rēgiā, domum 10 reuertĭtur et, Anchisae patri 11 sacra Penatēsque committēns, suis eum impōnit uměris et cum Ascaniō filiō Creusāque uxōre fugam capit. Creūsa autem inter eundum 12 deerrat. Tunc Aenēas imměmor pericŭli iter ad eam quaerendam ${ }^{13}$ relēgit; sed, cum uxōrem inuenire nōn posset 14 (nam dea Cybělē Creūsam in Phrygiam portauěrat), Idam montem petit, ubi cum nōnnullis Trōiānis è caede èlapsis fugam parat.

Sic periit 15 Trōia et magna Trōianōrum glōria.

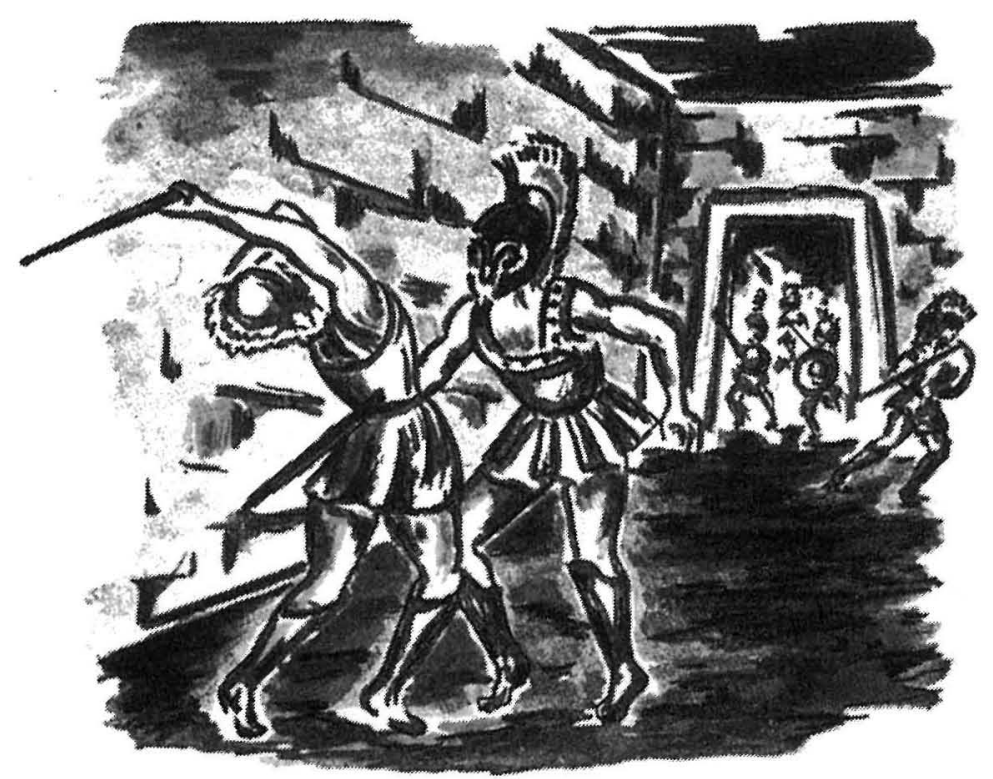




\section{NOTAS}

1 Note o complemento circunstancial de lugar para onde sem preposição (in), por se tratar de um nome de cidade.

2 O verbo statuère 'resolver; decidir' constrói-se com uma oração integrante de $u t+$ conjuntivo.

$3 \mathrm{O}$ verbo intrāre 'entrar em; transpor' tanto se pode construir com simples acusativo, como com um complemento de lugar para onde (in + acusat.).

4 Note o locativo (Tröiae 'em Tróia'), de regra com os nomes de cidades dos temas em $a$ e $o$ do singular. Assim: Rōmae 'em Roma'; Aeminii 'em Coimbra'; Corinthi 'em Corinto'; Lutētiae 'em Paris'; Londinii 'em Londres'; etc.

5 O verbo nescire 'não saber' constrói-se com uma oração infinitiva (sujeito - diem illum - em acusativo e predicado no infinito - futūrum esse 'seria; havia de ser'): vd. p. 212 sqq.

6 Sobre este vocativo, vd. p. 56, n. 2 .

7 Sociōs 'como ou por companheiros': nome predicativo do complemento directo (hōs).

8 Note o género de diēs: vd. cap. XII, linha 1 (p. 221) e p. 91.

9 Pirro (ou Neoptólemo), um dos heróis gregos que combateram contra Tróia, era filho de Aquiles.

$10 \mathrm{O}$ complemento de lugar para onde com domus não leva preposição.

11 patri... filiō... uxōre 'a seu pai... (com) seu filho... (e) sua esposa'.

12 inter eundum 'enquanto caminha(m)': eundum é o acusativo do gerúndio do verbo ire (vd. pp. 236 e 268-270).

13 ad eam quaerendam 'para a procurar': expressão final com ad + acusativo do gerundivo (vd. p. 248 sqq.).

14 cum ... nōn posset 'como não pudesse (= como não conseguisse)': note a oração causal (cum + conjuntivo).

15 Quando o sujeito é múltiplo, tanto se pode usar o plural do verbo (periērunt), como o singular. 


\section{VOCABULÁRIO}

accēděre: aproximar-se

accipěre: aceitar imperat. accĭpe, ĭte

acriter: energicamente; com denodo

adìtus, us: entrada

in ipsō adĭtu portae: no preciso momento em que transpunha o limiar da porta

admittěre: deixar entrar

aegrē: com pesar; a custo

aggrědi [verbo depoente]: atacar aluus, i: ventre; bojo

Anchisēs (-a), ae: Anquises apertus, a um: aberto

arma, örum: armas

armātus, a, um: armado

armāti, ōrum: soldados; homens armados

arx, arcis: cidadela

Ascanius, ii: Ascânio

attonitus, a, um: cheio de entusiasmo; aturdido

caděre: cair

caedēs, is: massacre

caněre: cantar; entoar

capěre: tomar

fugam capĕre: pôr-se em fuga carmen, ùnis: canto; cântico; hino casus, us: desventura

clauděre: encerrar

committěre: confiar

conděre: fundar

coniunctus, a, um: reunido

conuolāre: acorrer juntamente

Creūsa, ae: Creúsa

Cybělē (-a), ae: Cíbele deerrāre: perder-se

dēscendĕre: descer

dum: enquanto

ecce: eis que

èděre [não confundir com ěděre 'comer']: deixar sair; produzir pret. perf. do ind. ēdĭdi

ēgressus, a, um: saido

ē naui ēgressus: desembarcado; que havia desembarcado

èlapsus, a, um: escapado

ēuertěre: abater; deitar abaixo; derrubar

exanìmis, e: morto; inanimado excitāre: despertar

excuby̆tor, ōris: sentinela

exscidium, ii: destruição

extrēmus, a, um: último; derradeiro

festiuus, a, um: festivo

fraus, fraudis: prejuizo; embuste; armadilha

fugěre: fugir imperat. fuge, ite

funděre: espalhar; dispersar

funis, is: corda

gemitus, us: gemido

Hector, oris: Heitor

heu: ai!

hilăris, e: alegre; exultante

immānis, e: enorme; gigantesco

imměmor, ŏris: esquecido; sem pensar

impedītus, a, um: carregado; embaraçado

uinō ac somnō impedītus: carregado de vinho e de sono; 
mergulhado no vinho $e$ no sono

impōnĕre: colocar sobre

uměris impōnĕre: pôr aos ombros

imprōuľdus, a, um: imprevidente incenděre: incendiar inducěre: levar inflammātus, a, um: inflamado; em chamas

inicěre [+ dat.]: lançar $a$ insania, ae: loucura; paixão interficěre: matar part. pass. interfectus, a, um intěrim: entretanto intǐmus, a, um: o mais fundo inuehěre: arrastar; levar inuenire: encontrar irruēns, entis: que se precipita; que ataca

iter, itiněris: caminho

lassus, a, um: cansado

latēns, entis: que está escondido; - escondido

litus, ŏris: praia ; costa (marítima)

locāre: instalar

loqui (verbo depoente): falar part. pass. locūtus, a, um magis: mais

magis magisque: mais e mais; cada vez mais

minans, antis: que ameaça; ameaçador

murus, i: muralha

nōnnullus, a, um: algum

nox, noctis: noite

occaecātus (obc-), a, um: cego; obcecado

occisus, a, um: morto

opus, ěris: trabalho örnāre: enfeitar; decorar

parāre: preparar

passim: por toda a parte

pectus, oris: peito

ex intĭmō pectǒre: bem do fundo do peito

Penātēs, ium ou um: Penates (deuses protectores do lar ou da pátria)

pererrātus, a, um: percorrido

perire: perecer

pēs, pĕdis: pé; pata

petěre [+ acusat.]: dirigir-se para

porta, ae: porta (de cidade)

praefĕrēns, entis: que prefere; preferindo

prōfectus, a, um: que partiu; que veio; vindo

prōgrědi (verbo depoente): avançar

quaerĕre: procurar encontrar ; buscar

imperat. quaere, quaerǐte

quater: quatro vezes

ramus, i: ramo; ramagem

rēgia, ae: palácio real

relegĕre: tomar de novo; percorrer de novo

iter relegěre: voltar atrás

resistěre: parar (com resistência); deter-se

pret. perf. do ind. restíti

reuerti (verbo depoente): voltar;

regressar

rota, ae: roda

sacer, ra, rum: sagrado

sacra, ōrum: os objectos sagrados

saeuus, a, um: feroz

sic: assim 
silēns, entis: silencioso

silente nocte: no silêncio da noite

silëre: calar-se

pret. perf. do ind. silui

somnium, ii: sonho

somnus, i: sono

in somnis uisus est: apareceu em sonhos

sonus, i: som; ruido

sparsus, a, um: disperso

strepitus, us: ruído; barulho

stupa, ae: estopa

ex stupā: de estopa

subire [+ dat.]: atacar; dominar

suppōněre [+ dat.]: pôr debaixo suprēmus, a, um: último; derradeiro

summēns, entis; que agarra em; pegando

tamen: todavia; contudo

CONÍMBRIGA

- Camponês com um leitão. tandem: por fim; finalmente

tegēns, entis: que cobre; cobrindo

tempus, oris: tempo

tempus erat quō: era a hora em que

tenēre: ter; segurar; ser senhor de; apoderar-se

trahĕre: puxar

trahĕre gemitus: soltar gemidos; gemer

transire: atravessar; passar

turbāre: perturbar; agitar

turma, ae: destacamento; tropa

uarius, a, um: variado; diverso

uastāre: devastar

ululātus, us: grito (penetrante)

ululātus uarius: um clamor confuso

umbra, ae: sombra

uměrus, i: ombro

urgēre: insistir

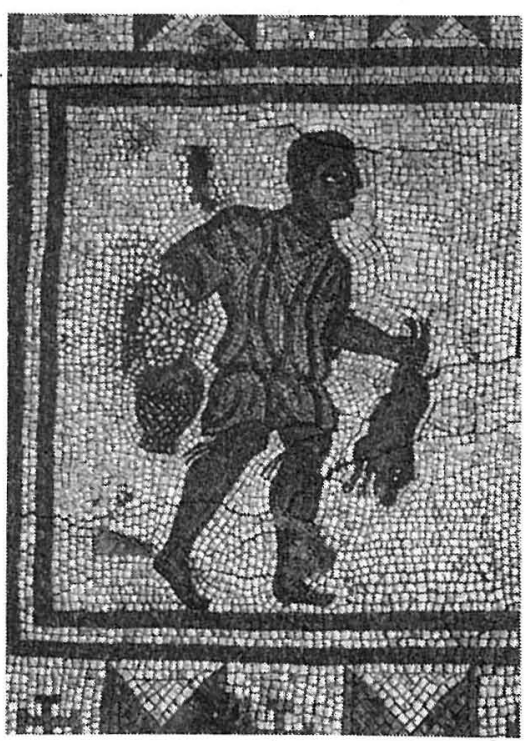




\section{GRAUS DOS ADJECTIVOS}

Superlativo absoluto e relativo:

Radical do positivo + -issimus, a, um

Exemplos:

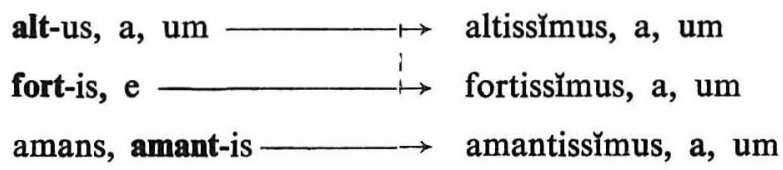

COMPLEMENTO DO SUPERLATIVO RELATIVO:

Cícero foi o mais ilustre dos oradores romanos

1 - Genitivo: Ōratōrum Rōmanōrum Cicěrō clarissǔmus fuit.

2-Apud + acusativo: Apud ōratōrēs Rōmānōs Cicěrō clarissǐmus fuit. 3-Inter + acusativo: Inter ōratörēs Rōmānōs Cicěrō clarissĭmus fuit. 4 -Ex (dē; in) +ablativo: Ex ōratōrĭbus Rōmānis Cicěrō clarissĭmus fuit.

EXERCÍCIOS:

Ulisses foi o mais astuto (astūtus, $a$, um) dos Gregos.

(1)

(2)

(3)

(4) 
Paulo é o mais cuidadoso (diligēens, entis) dos companheiros (collèga, ae).

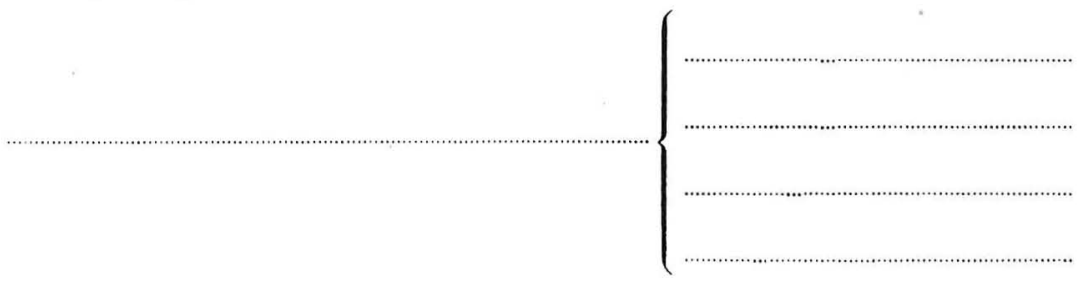

Dos animais terrestres o mais corpulento (praestans, antis) é o elefante (elephas, antis).

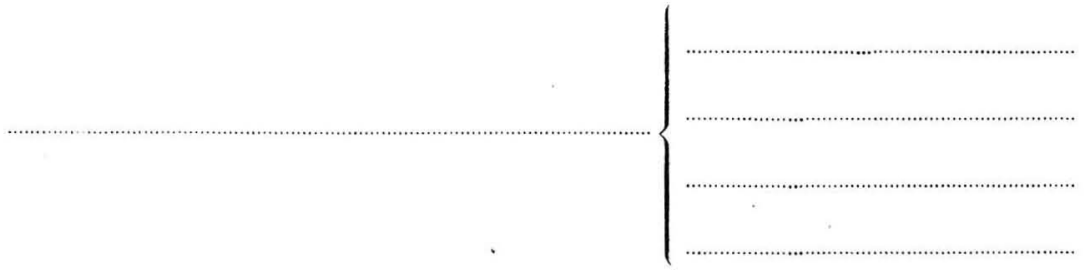

Como traduzir o superlativo absoluto:

Rēs agĭtur apud praetōrem popŭli Rōmāni, lēctissĭmum uirum, et apud sēuērissĭmōs iudícēs.

A questão é debatida ante um pretor do povo romano, homem tão distinto, e ante juizes tão austeros.

Litteratissimōrum homǐnum concursu, Cicĕrō prō Archiā, summō poètā atque èruditissimmō homīne, dixit.

Cícero falou em defesa de Árquias, excelso poeta e homem de vasta erudição, numa assembleia de varões tão ilustrados.

Antiochīa, celěbris quondam urbs Asiae et cōpiōsa, èruditissümis hominibus liberalissimisque studiis adfluēns fuit.

Antioquia, outrora populosa e rica cidade da Ásia, foi fértil de homens do maior saber $e$ em estudos da maior nobreza. 
Scipiō et Laelius moderatissümi homǐnēs et continentissĭmi fuērunt.

Cipião e Lélio foram homens de grande prudência e temperança.

Catō ille senex fortissı̆mus uir et illis temporibus doctisšmmus fuit.

O famoso Catão, o Velho, foi homem de grande vigor e cultura para o seu tempo.

Liberalium artium studia anı̆mi remissiō humanissima ac liberalissima sunt.

O estudo das artes liberais é uma recreação do espirito bem humana $e$ bem liberal.

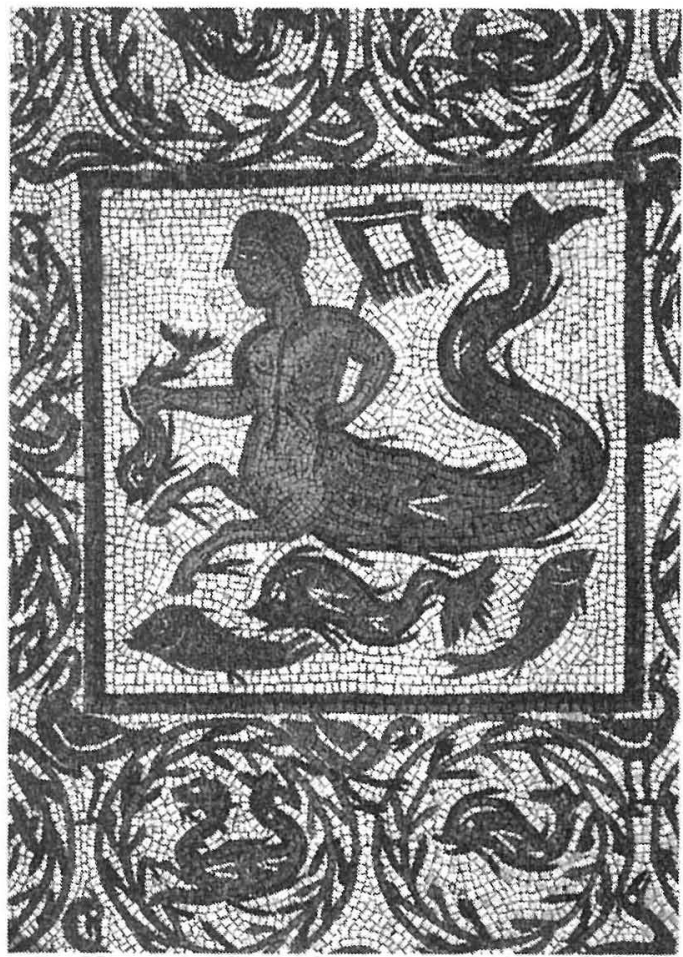

CONÍMBRIGA - Centauro marinho 


\section{Dē uxōre Sōcrătis philosŏphi}

Sōcrătēs philošophus omnium nōbilisšrmus ${ }^{1}$ uxōrem habēbat Xanthippēn 2. Fama est hanc muliěrem fuisse admŏdum mōrōsam atque iurgiōsam. Cuius intemperiēs in ${ }^{3}$ maritum Alcibiădēs dēmirātus, interrogauit Sōcrătem, quaenam ratiō esset ${ }^{4}$, cur muliĕrem tam odiōsam atque acerbam domō 5 nōn exigěret. "Quoniam», inquit Sōcrătēs, «cum illam talem domi 6 perpetior, insuēscō atque exerceor quō 7 cēterōrum quoque foris petulantiam et iniuriam facilius feram.»

1 philoš̆phus omnium nōbilissı̀mus: traduza como se estivesse nōbilisš̆mus omnium philosophorum.

2 Note a desinência de acusat. sing. de origem grega (= lat. -am).

3 in $(+$ acusat. de pessoa $)=$ contra.

4 Conjuntivo de uma oração interrogativa indirecta: vd. p. 277 sqq.

5 Note a ausência de preposição (ē ou ex) com domus.

6 Locativo (= lugar onde).

7 quō ... facilius feram: $q u \delta$ introduz regularmente uma oração final (predicado no conjuntivo), sempre que nela figura um comparativo.

\section{VOCABULÁRIO}

acerbus, a, um: azedo; áspero admǒdum: muito; extremamente cētěrus, a, um: restante cētěri, ōrum: os demais

cur: porquê?; por que razão?; por que; para que

dēmirātus, a, um: admirado exercēre: agitar; na pass. exercitar-se; treinar-se

exigĕre: expulsar domōō exǏgĕre: repudiar (uma mulher)

facilius (adv.): mais facilmente ferre: suportar

pres. do conj. feram foris: fora de casa iniuria, ae: agravo; insulto insuēscěre: ir-se habituando intemperiēs, ei: impertinência; desmando; destempero

iurgiōsus, a, um: amigo de discutir; embirrento

mōrōsus, a, um: rabugento

nōbǐlis, e: conhecido; famoso odiōsus, a, um: desagradável perpěti (verbo depoente): suportar petulantia, ae: insolência; ataque quisnam, quaenam, quidnam ou quodnam: quem? qual? que? quoque: também ratiō, ōnis: razão; motivo talis, e: $t a l$ ille talis: tal qual ele é Xanthippē, ēs: Xantipe (-a) 


\section{ADVÉRBIOS DE MODO}

1 -altus, a, um: genit. sing. masc. alt-i : alte $\bar{e}$ 'altamente; profundamente'

altius 'mais altamente; mais alto; mais profundamente'

altisšme $\bar{e}$ 'altissimamente; muito profundamente'

$2-$ grauis, $e$ : genit. sing. masc. grau-is: grau ťter

grauius

grauissìmé

3 -diligēns, genit. sing. masc. diligent-is: diligenter

diligentius

diligentissĭm $\bar{e}$

\section{A cultura e a religiosidade de Carlos Magno}

Karŏlus ille Magnus èloquentiā cōpiōsus et exubĕrans fuit. Nec patriō ${ }^{1}$ tantum sermōne 1 contentus, peregrīnas etiam linguas, Latinam atque Graecam, èdidǐcit. Nam Latinā aequē ac patriā linguā ōrāre solēbat; Graecam uērō melius intellegěre quam prōnuntiāre potěrat 2 .

Doctōres liberalium artium, quas studiōsissǐmē coluit, magnis afficiēbat honōrǐbus. In discendā grammatǐcā ${ }^{3}$ Petrum Pisānum audiuit. In cētěris disciplīnis Alcuinum, uirum undecumque doctisš̆mum, praeceptōrem habuit; apud quem et rhētorǐcae et dialectǐcae, praecipuē tamen astronomiae ēdiscendae ${ }^{4}$ plurřmum et temporris et labōris impertiuit. Discēbat artem computandi ${ }^{5}$ et intentiōne sagāci siděrum cursum curiōsissīmē rimabātur.

1 patriō ... sermőne: com a língua pátria; com a língua materna (i.e., alemão).

2 potĕrat: era capaz.

3 in discenda grammatíca: na aprendizagem da gramática.

4 astronomlae èdiscendae: ao estudo da astronomia. Note a acentuação de astronomía.

5 artem computandi $=$ arithmeticam. 
Religiōnem christiānam sanctisšmēē et cum summā pietāte coluit, ac propter hoc maxĭmae pulchritudĭnis basilǐcam Aquisgrāni 6 exstruxit. Ecclēsiam et mane et uespěri, item nocturnis hōris et sacrificii 7 tempŏre, quoad eum 8 ualētūdō permisěrat, impĭgrē frequentābat.

(Adaptado de Einhard, Vita Karoli)

6 Aquisgrăni: em Aix-la-Chapelle.

7 sacrificii: do sacrifício da missa.

8 eum: the.

\section{VOCABULÁRIO}

afficěre: cumular

audire: ser discipulo

basilǐca, ae: catedral

cētěrus, a, um: restante

colěre: cultivar

computāre: calcular

contentus, a, um: satisfeito

cōpiōsus, a, um: abundante

curiōsus, a, um: curioso; ávido de saber

cursus, us: marcha; movimento

discěre: aprender

doctǒr, ōris: mestre; professor

ecclēsia, ae: igreja

èdiscěre: aprender

exstruěre: (mandar) erguer;

(mandar) construir

impertire: consagrar; dedicar

impIger, ra, rum: diligente

intellegĕre: compreender

intentiō, ōnis: atenção

item: igualwente

laborr, ōris: trabalho; esforço

mane: de manhã

melius: melhor (advérbio)

nocturnus, a, um: nocturno; da noite

ōräre: falar peregrinus, a, um: estrangeiro

permittěre: permitir

piětas, ātis: piedade; respeito

plurĭmum: [+ genit. partitivo]

muito

praeceptŏr, ōris: mestre

praecipuus, a, um: particular ; especial

propter [+ acusat.]: por causa de pulchritūdō, Ǐnis: formosura; beleza

quoad: enquanto

religiō, ōnis: religião

rimāri: observar; investigar

sagax, ācis: sagaz; penetrante

sermō, ōnis: língua; linguagem

sidus, ěris: astro

solēre: costumar

studiōsus, a, um: aplicado; interessado

summus, a, um: o maior

tamen: porém

tantum: somente; apenas

ualētūdō, Ǐnis: saúde

uērō: no entanto

uespěri: à tarde

undecumque: em todos os aspectos 


\title{
CONJUGAÇÃO VERBAL
}

\author{
Voz activa
}

Particípio presente: -ns, -ntis

laudā-ns, -antis louvando

dēlē-ns, -entis destruindo

monē-ns, -entis advertindo

reg-ē-ns, -entis governando

capi-ē-ns, -entis conquistando

audi-ē-ns, -entis ouvindo

Participio futuro: -ūrus, a, um

futūrus, $a$, um 'o que há-de ser'

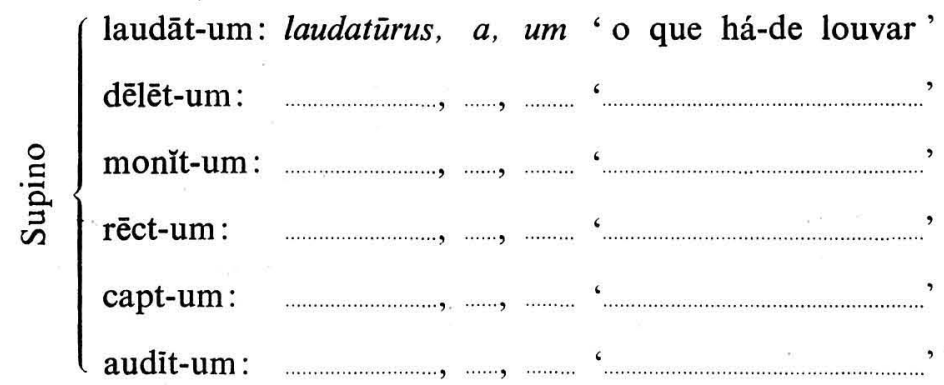

Infinitivo futuro:

fore ou $\left\{\begin{array}{l}\text { futūrum, am, um } \\ \text { futūrōs, as, a }\end{array}\right\}$ esse 'haver de ser'

$\left.\begin{array}{l}\text { laudatūrum, am, um } \\ \text { laudatūrōs, as, a }\end{array}\right\}$ esse 'haver de louvar' 
dēlētūr

..

monǐtūr

\}

rēctūr

\}

……............................

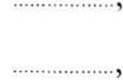

captūr

audītūr

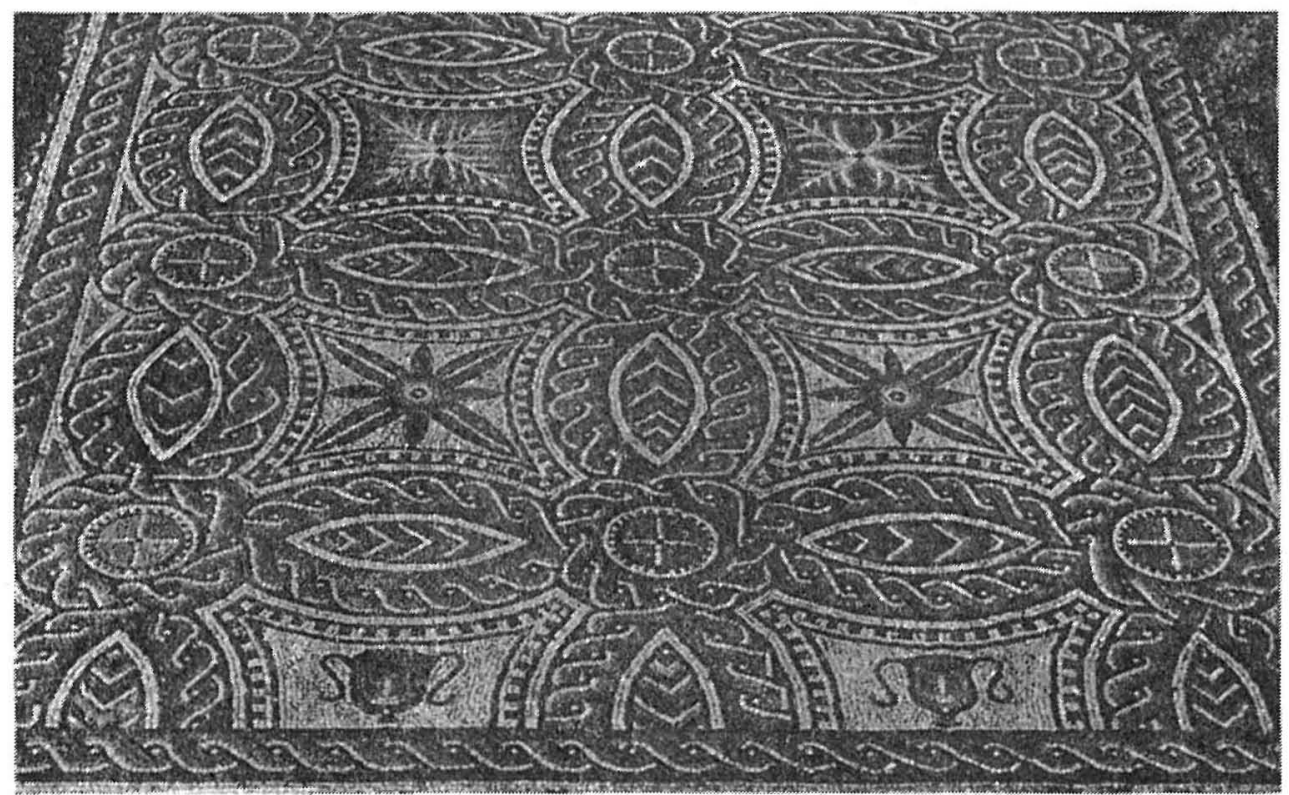

CONIMBRIGa. Mosaico. 
Gerúndio:

\begin{tabular}{|ll|}
\hline Ac. & -ndum \\
G. & -ndī \\
D. & -ndō \\
Ab. & -ndō \\
\hline
\end{tabular}

Ac. laudandum para louvar

dēle

G. laudandi de louvar

D. laudandō a louvar

Ab. laudandō louvando

Ac. mone

rēge

G.

D.

Ab.

Ac. capie

audie

G.

D.

Abl

IMPORTANTE:

Com os verbos intransitivos ou com os transitivos sem compl. directo expresso pode usar-se o acusativo do gerúndio regido da preposição ad ou o genitivo acompanhado de causā ou gratiā para exprimir o fim. 
BXEMPLOS:

para amar: ad amandum

ou

amandi causa (ou gratia)

para destruir: ad dēlendum

ou

delendi causa (ou gratia)

para governar: ad rēgendum

ou

rēgendi causa (ou gratia)

para tomar: ad capiendum

ou

capiendi causa (ou gratia)

para ouvir: ad audiendum

ou

audiendi causa (ou gratia)

\section{Verta para Iatim:}

Eu estou na cidade [de] Coimbra para estudar (studère).

Os alunos estão na escola para aprender (discĕre) e os professores para ensinar (docēre).

As tropas estão preparadas (parātus, $a, u m$ ) para atacar (oppugnāre).

Eles levantaram-se (surgĕre: pret. perf. ind. surrēxi) para ver (uidēre) melhor (acrius). 


\section{A Cícero}

Disertissŭme Römŭli nepōtum, quot sunt quotque fuēre 1, Marce Tulli 2, quotque post aliis erunt in annis ${ }^{3}$, gratias tibi maximas Catullus agit pessŭmus omnium poēta, tantō pesš̌mus omnium poēta quantō tu optǐmus omnium patrōnus.

(Catulo, Carmina, 49)

1 fuëre $=$ fuërunt.

2 Vd. p. 56, nota 2.

3 post aliis ... in annis 'em anos futuros'.

\section{VOCABULÁRIO}

agěre: levar

gratiās agěre: agradecer

Catullus, i: Catulo

disertus, a, um: diserto; (orador) hábil

Marcus, i: Marco

nepōs, ōtis: neto; descendente

patrōnus, i: advogado

quot (indeclinável): quanto $(s)$

Tullius, ii: Túlio 


\section{CONJUGAÇÃO PERIFRÁSTICA}

Voz activa

N.B.:

$$
\text { particípio futuro + esse }
$$

Exemplo:

laudatūrus, a, um dēlētūrus, a, um monitūrus, a, um rēctūrus, a, um captūrus, a, um auditūrus, a, um laudatūri, ae, a dēlētūri, ae, a monitūri, ae, a rēctūri, ae, a captūri, ae, a auditūri, ae, a

IMPORTANTE:

A perifrástica activa exprime a intenção do sujeito.

Assim, por exemplo:

laudatūrus sum $\left\{\begin{array}{l}\text { eu hei-de louvar; } \\ \text { eu estou para louvar; } \\ \text { eu estou disposto a louvar; } \\ \text { é minha intenção louvar; } \\ \text { etc. }\end{array}\right.$

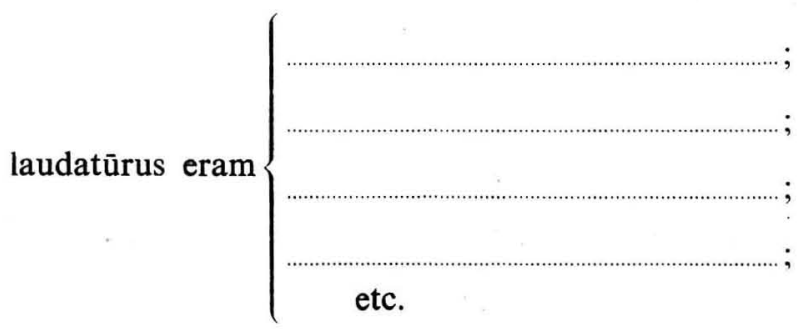


EXEMPLOS:

Cicĕrō hanc causam actūrus est (agĕre: supino actum).

Cícero tem a intenção de defender esta causa.

Comoedus hanc comoediam actūrus erat.

O actor tencionava representar esta comédia.

Carthaginiēnsēs impětum in exercǐtum Rōmanōrum factūri fuērunt (facère: supino factum).

Os Cartagineses estiveram para atacar o exército romano.

E X E R C Í C I OS :

Lúcia vai (=está para) escrever (scribere: supino scriptum) uma carta ao ( $a d+$ acusat.) pai.

O pastor (pastor, öris) tinha a intenção de levar (agĕre: supino actum) o rebanho (grex, gregis) para o prado (pratum, $i$ ).

Os rapazes e as raparigas estavam dispostos a dançar (saltāre: supino saltātum).

António, tu vais ler (legère: supino lēctum) este livro (liber, ri). 
O historiador (rërum scriptor, öris) romano Salústio (Sallustius, ii) tencionava descrever (scribëre) a guerra que o povo (popülus, $i$ ) romano fizera (gerëre: pret. perf. ind. gessi) contra $(=\mathrm{com})$ Jugurta (Iugurtha, ae), rei dos Númidas (Numidae, ārum).

Paula tenciona ir (ire: supino itum) a Roma.

Era nosso intuito escrever aos nossos amigos.

Paulo, tu hás-de ir visitar (uisěre: supino uisum) o museu (Musêum, $i$ ).

Escutem o que (quae) vou dizer (dicěre: supino dictum).

Os gladiadores (gladiātor, öris) costumavam saudar (salutāre) o Imperador com estas palavras (uerbum, $i$ ): «Salve (auē), César, os que vão morrer (moritūrus, $a, u m$ ) te saúdam.»

As tuas irmãs (soror, ōris) estavam para sair (exire: supino exĭtum), quando (cum) tu chegaste (aduenire: pret. perf. ind. aduēni). 


\section{Dê auspiciis}

Antiqui Rōmāni, ut scitur, solēbant auium uolātum obseruāre aut famem, ut 1 futüra praenōscěrent. Rōmae ${ }^{2}$ enim erant pulli sacri, quōs petēbant quotiēscumque alĭquid graue ēuentūrum erat: si pulli libenter pascēbantur, bonum erat auspicium; si èsse ${ }^{3}$ nōlèbant, malum. Narrātur ducem quemdam, nōmǐne Publium Claudium, cum ${ }^{4}$ proelium nauāle cum Carthaginiēnsǐbus committĕre uellet, auspicia mōre maiōrum petiuisse et, pullariō nuntiante pullōs nec exīre $\overline{\mathrm{e}}$ caueā nec ēsse uelle, irātum ${ }^{5}$ iussisse ${ }^{6}$ eōs in mare abici dicentem: — Quia ēsse nōlunt, bibant! 7

1 ut + conjuntivo: oração final. Cf., linha 1, ut + indicativo: oração comparativa ou explicativa.

2 Romae: locativo (= lugar onde).

3 Esse (não confundir com èsse 'ser; estar') = èdère 'comer'.

4 cum + conjuntivo: oração causal.

5 irătum ... dicentem: acusativos a concordar com ducem quemdam.

6 Vd. p. 217 sq.

7 Conjuntivo optativo: 'que bebam!'

\section{VOCABULÁRIO}

abicěre: lançar

auis, is: ave

auspicium, ii: auspicio

cauea, ae: gaiola

committěre: iniciar

proelium committěre: travar

um combate

ēuenìre: acontecer; suceder

supino ēuentum

exīre: sair

famēs, is: fome; apetite

futūra, ōrum: as coisas que hão-de acontecer; o futuro

libenter: com apetite

mōs, mōris: costume

mōre maiōrum: segundo um costume ancestral

naualis, e: naval nōlle: não querer

3. ${ }^{a}$ p. pl. do pres. do ind.: nōlunt pret. imperf. do ind.: nōlēbam pascĕre: apascentar; na pass. alimentar-se (falando de animais) petěre [+ acusat.]: interrogar; consultar

praenōscěre: adivinhar

proelium, ii: combate

pullarius, ii: áugure

pullus, i: frango

quia: já que

quotiēscumque: sempre que

scire: saber

solēre: costumar

uelle: querer; pretender

pret. imperf. do conj. uellem uolātus, us: voo 


\section{GRAUS DOS ADJECTIVOS}

CASOS PARTICULARES

1-Tal como acontece em português, os seguintes adjectivos formam o comparativo e o superlativo de modo particular:

$$
\begin{aligned}
& \text { bonus 'bom' — melior, ius — optǐmus, a, um } \\
& \text { malus 'mau' —_ peior, peius — pessĭmus, a, um } \\
& \text { magnus 'grande' - maior, maius - maxĭmus, a, um } \\
& \text { paruus 'pequeno' - minor, minus - minǐmus, a, um } \\
& \text { multi 'muitos' - plurēs, plura - plurǐmi, ae, a } \\
& \text { genit. plurium }
\end{aligned}
$$

N.B. :

maior natu o mais velho (de dois)

minor natu o mais novo (de dois)

maxumus natu o mais velho (de vários)

minǐmus natu o mais novo (de vários)

$2-O$ superlativo dos adjectivos terminados em -er no positivo (1. ${ }^{\mathrm{a}}$ e $2 .^{\mathrm{a}}$ classes) forma-se com a terminação -rimus:

1.a classe: $\begin{cases}\text { liber } & \text { liberrĭmus, a, um } \\ \text { pulcher } & \text { pulcherrìmus, a, um }\end{cases}$

2. ${ }^{\mathrm{a}}$ classe: celer celerrimus, a, um 
3- Note-se a semelhança com o português dos superlativos dos seguintes adjectivos:

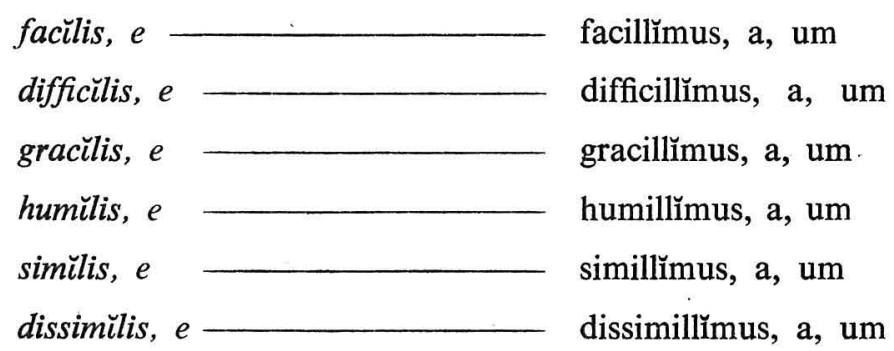

4 - Os adjectivos terminados no positivo em -diccus (de dicëre 'dizer'), -fícus (de facère 'fazer') e -uŏlus (de uelle 'querer') formam o comparativo juntando ao radical a terminação -entior, -entius; e o superlativo, a terminação-entissimus, $a$, um.

Assim, por exemplo:

maledǐcus —-maledicentior, ius — maledicentisš̆mus, a, um maleficus —-maleficentior, ius — maleficentissimus, a, um maleuŏlus —-maleuolentior, ius —— maleuolentissŭmus, a, um

Outros exemplos:

benedicus,

beneficus,

beneuŏlus,

5 - Os adjectivos terminados no positivo em -eus, -ius e -uus formam o comparativo e o superlativo analiticamente:

idōneus — magis idōneus - maximē idōneus necessarius — $\$ necessarius —— necessarius arduus — $"$ arduus — $\longrightarrow$ arduus 


\section{Apellēs ad sutōrem 1}

Apellēs, Graecus pictor praeclarissimmus, perfecta opĕra transeuntĭbus prōpōnēbat in pergŭlä, et post tabŭlam latēns iudicia reprehensiōnēsque uarias, quae notarentur ${ }^{2}$, auscultābat, uulgum diligentiōrem iudǐcem quam sē praefěrēns 3 .

Fertur ${ }^{4}$ sutōrem nesciō quem aliquandō in figūrae cuiusdam crepūdā uitium notauisse, quod ${ }^{5}$ Apellēs sponte suā ēmendāuit. Cum ${ }^{6}$ uērō postěrō diē idem ${ }^{7}$ dēnuō accēdēns ēmendatiōnem uidisset, sibi placēns 8 ausus est uitium altěrum in crure eiusdem figūrae notāre. Tunc Apellēs sēsē 9 ostendēns: «Nē sutor», inquit, «supra crepǐdam ascendat $10 . »$ Quod in illud contra imperītōs iudǐcēs prouerbium uēnit 11: nē sutor supra crepĭdam. 12

1 Em títulos de capítulos ou de fábulas, p. ex., a preposição ad 'para' poderá traduzir-se pela copulativa 'e'.

2 Conjuntivo potencial: 'que fossem (= que pudessem ser) apontadas'.

3 Dê um valor causal a este particípio presente: 'por considerar'.

4 Vd. orações infinitivas (p. 212 sqq.).

5 Tem por antecedente o neutro uitium.

6 Cum + conjuntivo: oração causal.

7 Referido a sutor: poderá, no entanto, traduzi-lo por 'o mesmo fulano'.

8 sibi placēns 'satisfeito (ufano; desvanecido) consigo mesmo'.

9 Note o reforço do pronome pessoal da terceira pessoa.

10 ne + conjuntivo $=$ imperativo negativo.

11 Quod... uẽnit 'Daqui nasceu o adágio contra os que dão voto no que não entendem' (à letra: 'Isto passou para aquele adágio contra os críticos ignorantes').

12 Subentenda-se ascendat (vd. supra, nota 10). O provérbio português com sentido aproximado é: 'Quem te manda a ti sapateiro tocar rabecão', ou, mais à letra: 'Não vá o sapateiro além da chinela'. Também ocorre a variante: ultra crepidam. 


\section{VOCABULÁRIO}

accēdĕre: aproximar-se

accēdēns, entis: que se apro-

xima; ao aproximar-se

aliquandō: uma vez; certa vez

Apellēs, is: Apeles

ascenděre: subir

ascendĕre supra [+ acusat.]:

ir além de

audēre (verbo semidepoente): ousar; atrever-se

pret. perf. do ind. ausus sum

auscultāre: escutar; pôr-se d̀ escuta

crepǐda, ae: sandália; chinela

crus, cruris: perna

dēnuō: novamente; de novo

dilĭgēns, entis: consciencioso

ēmendāre: corrigir

ēmendatiō, ōnis: emenda; correç̧ão

iudex, Ǐcis: juiz; crítico

iudicium, ii: opinião; crítica

latēre: esconder-se

nesciō quis ou qui, nesciō quae

ou qua, nesciō quid ou quod:

um qualquer.

notāre: apontar opus, ěris: obra

opus perfectum: obra já concluída

ostendĕre sē: aparecer

praefěrēns, entis: que prefere; que

considera

perfectus, a, um: acabado

pergŭla, ae: varanda; oficina

pictor, ōris: pintor

postěrus, a, um: seguinte

postěrō diē: no dia seguinte

praeclārus, a, um: notável; ilustre

prōpōněre: expor

reprehensiō, ōnis: censura

sponte: espontaneamente

sponte suā: de sua livre von-

tade; voluntariamente; de bom grado

supra [+ acusat.]: acima de; além de

sutor, ōris: sapateiro

tabŭla, ae (subent. picta): quadro

(pintado)

transiēns, transeuntis: trauseunte uērō: no entanto

uitium, ii: defeito; imperfeição

uulgus, i: o povo anónimo 


\title{
CONJUGAÇÃO VERBAL
}

\author{
Voz passiva
}

Supino: -̄̄ (ablativo)

laudātu de ser louvado

dēlētu de ser destruído

monĭtu de ser advertido

rēctu de ser governado

lēctu de ser lido

captu de ser capturado

auditu de ser ouvido

\section{N.B.:}

mirabile dictu 'coisa maravilhosa de se dizer' horribile auditu 'coisa horrível de se ouvir'

Infinitivo futuro: supino activo + iri

laudātum iri 'haver de ser louvado'

dēlē..

monĭ.

rēc

lēc.

cap.

audi 
Gerundivo: tema + -ndus, a, um

laudandus, a, um 'que deve ser louvado' dēle

mone

regendus, a, um 'que deve ser governado'

leg.

capiendus, a, um 'que deve ser conquistado'

audi

IMPORTANTE (vd. pp. 236-237):

Com os verbos transitivos (com o compl. directo expresso) pode usar-se o acusativo do gerundivo regido da preposição ad ou o genitivo acompanhado de causā ou gratiā para exprimir o fim.

EXEMPLOS:

para amar o pai: ad patrem amandum

ou

patris amandi causa (ou gratia)

para amar a mãe: ad matrem amandam

ou

matris amandae causa (ou gratia)

para amar a guerra: ad bellum amandum

ou

belli amandi causa (ou gratia)

para amar os filhos: ad filiōs (ou libĕrōs) amandōs

ou

filiōrum (ou liberōrum) amandōrum causa

(ou gratia) 
para amar as filhas: ad filias amandas

ou

filiārum amandārum causa (ou gratia)

para amar as guerras: ad bella amanda

ou

bellōrum amandōrum causa (ou gratia)

Verta para latim:

I - para ensinar o aluno

para ensinar a aluna

para ensinar os alunos

para ensinar as alunas

para destruir o exército (exerč̌tus, us)

para destruir a cidade

para destruir os exércitos

para destruir as cidades 
para destruir o templo (templum, i)

para destruir os templos

para ler (legëre) o livro (liber, ri)

para ler a carta (epistŭla, ae)

para ler os livros

para ler as cartas

para comer (= tomar alimento: caperre; cibus, $i)$

para beber (= tomar uma bebida; feminino pōtiō, ōnis)

para ocupar (=tomar) os montes

para atingir (caperre) as ilhas

para tomar uma decisão (cōnsilium, ii) 
para tomar decisões

para ouvir o professor

para ouvir os professores

para ouvir a música (musica, ae)

para ouvir as queixas (querēla, ae)

para atribuir (tribuěre) uma recompensa (praemium, ii)

para distribuir (tribuěre) os prémios (praemium, ii)

para distribuir os livros

para distribuir as cartas

II - Estamos cá (hic) para aprender latim (lingua, ae; Latina, ae)

Os professores estão na escola para ensinar os alunos 
Ele sentou-se (siděre: pret. perf. ind. sēdi) para escrever (scribère) uma carta aos (ad + acusat.) pais

As tropas romanas atacaram (impètum facère in + acusat.; pret. perf. ind. fêci) os inimigos (hostēs, ium) para ocupar (capère) o acampamento.

Particípio passado: vide p. 156.

\section{CONJUGAÇÃO PERIFRÁSTICA}

(Vd. p. 239 sqq.)

Voz passiva

N.B.:

gerundivo + esse

Exemplo:

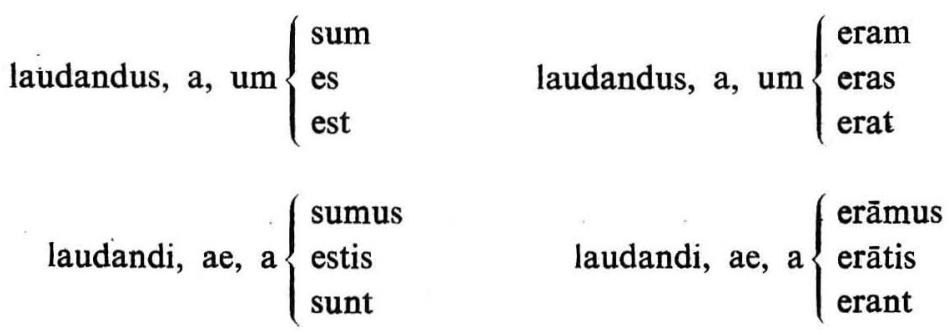


IMPORTANTE :

A perifrástica passiva exprime o dever, a necessidade.

Assim, por exemplo:

laudandus sum 'eu devo ser louvado'.

laudandi erant 'eles tinham de ser louvados'.

monenda erit 'ela terá de ser avisada'.

EX E R C I C I O S :

Virtus omnibus hominibus colenda est.

Parentēs liberris amandi sunt; libĕri parentı̌bus amandi sunt.

Quid tibi dicendum est?

Nihil erit nōbis magis timendum quam bellum ciuile.

Littĕrae (vd. p. 16) mihi scribendae erant.

Hi libri nōbis legendi erunt. 


\section{Agente da perifrástica passiva}

Como se pode ver pelos exemplos anteriores, o agente da perifrástica passiva exprime-se em dativo.

Quando, em português, a frase com dever, etc., estiver na voz activa, força é passá-la para a passiva antes de ser vertida para latim.

Assim, por exemplo:

1. Devemos amar a Deus.

2.0 Deus deve ser amado por nós.

3. Deus nōbis amandus est.

EXERCICIOS:

1. Eneias e os companheiros tiveram de abandonar (relinquerre) Tróia.

2.0 Tróia teve de ser abandonada por Eneias e pelos companheiros.

3.0

1. Os Romanos tinham de destruir Cartago (Carthāgō, innis).

2.0

3.0 
Cícero tem de defender (agére) a causa (causa, ae) perante (apud + acusat.) os juízes.

Os Cartagineses (Carthaginiēnsēs, ium) tinham de atacar (oppugnāre) as tropas romanas.

Os Romanos tiveram de destruir (dèlēere) Cartago (Carthāgō, inis).

$\mathrm{O}$ actor (actor, öris) terá de representar (agère) esta comédia (comoedia, ae).

Paula tem de escrever (scriberre) uma carta ao (ad+acusat.) pai.

António teve de ler (legère) estes livros (liber, ri).

Os pastores (pastor, öris) terão de levar (agĕre) os rebanhos (grex, gregis) para o prado (pratum, $i$ ). 
OBSERVAÇÕES

1 - Quando, na frase latina, já houver um outro dativo, o agente da perifrástica passiva segue a regra do agente da passiva (vide p. 38):

Lègibus a nōbis parendum est.

Mihi liber a tē dōnandus est.

2 - Quando, como no primeiro dos exemplos anteriores, a frase portuguesa não tem complemento directo, a frase latina fica sem sujeito, tornando-se assim impessoal (neutro do gerundivo).

Assim, por exemplo:

Nōbis studendum est.

Fugiendum uōbis fuit.

Eundum est mihi Olisipōnem.

EXER C I C I O S :

Eu tinha de estudar (studēre).

Os soldados (miles, ı̌tis)têm de fugir. 
Vocês tiveram de ir a Lisboa.

Tu tens de escrever (scriběre).

Nós temos de partir (pröficisci: verbo depoente: gerundivo prōficiscendus, a, um).

António tem de dormir (dormìre).

Júlia e Cláudia têm de cantar (canère).

Nós tivemos de dançar (saltāre).

Tu terás de ensinar (docēre).

Os alunos têm de aprender (discëre).

As tropas tinham de lutar (pugnāre).

Nós precisamos de comer (edère). 
Vocês tiveram de falar baixinho (muttire), mas nós tivemos de gritar (clamāre).

Cláudia, tu precisas de te levantar (exsurgère).

\section{Euripidès, poèta sibi cōnscius artis suae}

Eurip̆̀nēs ille ${ }^{1}$ poèta fabŭlam aliquandō Athēnis dabat. Cum ${ }^{2}$ popŭlus postulāret ut 3 ex tragoedia quamdam sententiam tollěret, prōgressus in scaenam: "Soleō fabŭlas compōněre», inquit, «ut ${ }^{4}$ uōs doceam, nōn ut ${ }^{4}$ a uōbis discam.»

Idem ${ }^{5}$ cum ${ }^{2}$ apud 6 tragicum quemdam poētam quererētur quod 2 eō triduō nōn ultra trēs uersus dēducĕre potuisset ${ }^{7}$, atque is ${ }^{8}$ sē centum perfacile scripsisse glōriarētur: «Sed hōc», inquit, «interest ${ }^{9}$, quod uersus tui in triduum tantummŏdo sufficient, mei uērō in omne tempus manēbunt.»

1 Emprego enfático do pronome: traduza por 'o célebre'.

2 Conjunção causal ( + conjuntivo).

3 Conjunção integrante (+ conjuntivo).

4 Conjunção final ( + conjuntivo).

5 Traduza por 'O mesmo Eurípides'.

6 Vd. pág. 42, 1.

7 'tinha sido capaz de; conseguira': vd. conjugação de posse nas pp. 263-264.

8 Isto é, o tal poeta trágico, em casa do qual Eurípides se encontrava.

9 Sed hoc interest, quod... «Mas há uma diferença, é que...» 


\section{VOCABULÁRIO}

aliquandō: certo dia; certa vez ars, artis: arte; talento; mérito; valor

centum (indecl.): cem; um cento; uma centena

compōněre: compor (= escrever) cōnscius, a, um: cônscio

sibi cōnscius (+ genit.): consciente da sua

dēducěre: produzir

uersus dēducĕre: compor (=escrever) versos

discěre: aprender

ab alĭquō discěre: aprender [alguma coisa] com alguém docēre: ensinar

Euripĭdēs, is: Euripides

fabŭla, ae: peça (de teatro)

fabŭlam dare: apresentar uma peça

glōriāri (depoente) : jactar-se; vangloriar-se; gabar-se

manēre: permanecer

in omne tempus manēre: resistir para sempre (= nunca mais ser esquecido) perfacile: com toda a facilidade popŭlus, i: povo; (o conjunto dos) espectadores

postulāie: pedir

prōgrědi (depoente) : avançar

in scaenam prōgressus: tendo

entrado em cena; tendo subido

ao palco

queri (depoente): queixar-se; lamentar-se

quidam, quaedam, quoddam ou quiddam: certo; um certo scriběre: escrever sententia, ae: frase; expressão solēre: costumar; estar habituado sufficĕre: durar

tantummŏdo: só; somente; apenas tollĕre: tirar; retirar; suprimir; cortar (uma frase num texto) triduum, i: espaço de três dias eō triduō: nos últimos três dias

in triduum: (durante) três dias

uērō: ao passo que

ultra: mais do que

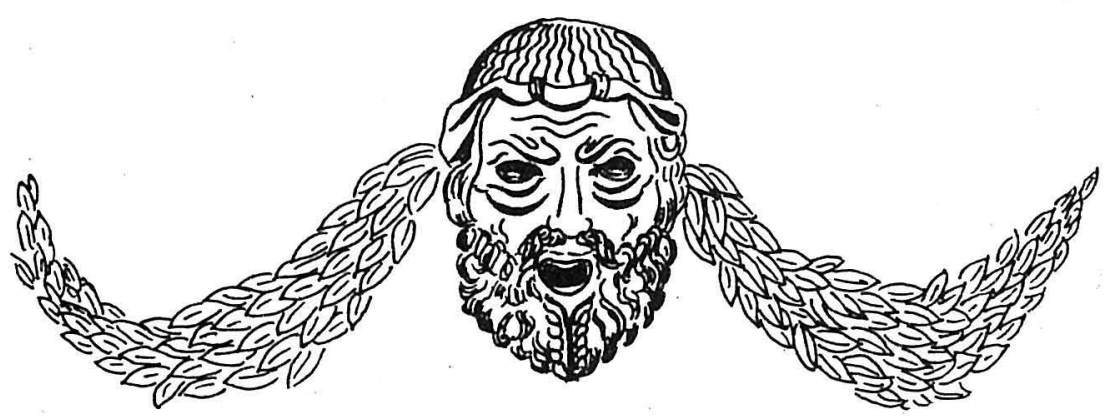




\section{ORAÇÕES INFINITIVAS}

(Continuação: vd. p. 212 sqq.)

E X E R C f C I O S (vd. infinitivo futuro, pp. 234-235):

Eu afirmo que António há-de ser bom.

Nós afirmamos que António e Lúcio hão-de ser bons.

Tu bem vês que Lúcia há-de ser má (malus, $a$, um).

Eles crêem que Lúcia e Paula hão-de ser más.

Disseram-me que o agricultor vai lavrar o campo.

Tu disseste que o campo vai ser lavrado pelo agricultor (vid. p. 247).

Paulo dizia que os agricultores iam lavrar o campo.

Diz-se que as tropas vão destruir o acampamento do(s) inimigo(s). 
Dizem que eles (=aqueles) vão chegar (aduenire: supino aduentum) hoje (hodiē).

Informaram-me de que a Júlia vai ler este livro (liber, ri).

Informo-te de que a Paula e a Júlia vão ler estes livros.

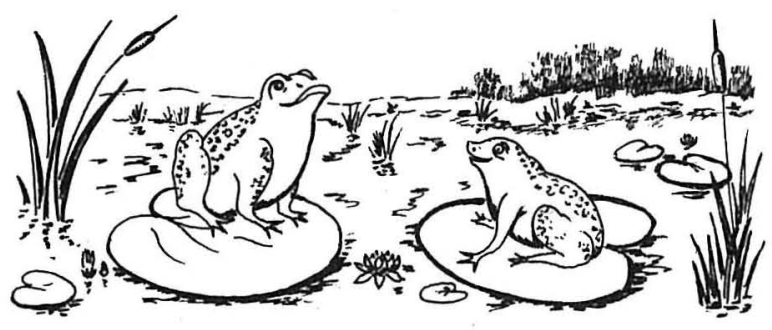

Ranae rēgem ab Ioue petentēs

Ōlim ranae in stagnō liběrē natantēs rēgem petēbant ab Ioue. Pater deōrum ridēns illis dat paruum tigillum, quod in uada subǐtō missum eas terret. Paulō post una dē illis caput ē stagnō tač̌tē prōfert et uidēns rēgem esse tigillum alias ēuǒcat. Illae timōre poš̆tō certātim ad tigillum adnātant et super id petulantēs insiliunt. Tali rēge sic inquinātō, ranae alium rēgem petunt ab Ioue. Tum deus illis mittit hydrum saeuum, qui statim incĭpit singŭlas uorāre. Qua dē causa ranae afflictae a deō rēgem dēnǔō petunt. Tunc contra Iuppǐter irātus: "Quia noluistis bonum uestrum ferre», inquit, «cum in stagnō liběrē natabātis, nunc malum perferte.» 
adnatāre: nadar para

afflictus, a, um: desesperado

bonum, i: $o$ bem

certātim: à porfia

contra: em resposta

cum: quando

dēnuō: novamente

ēuocāre: chamar̃ (para fora)

ferre: suportar

hydrus, i: hidra (cobra de água)

incipěre: começar

inquinātus, a, um: desacreditado tali rēge sic inquinātō: desacreditado assim um tal rei

insilïre: saltar (sobre)

libĕrē: livremente; sem receio

malum, i: o mal

missus, a, um: lançado

mittěre: enviar

natans, antis: que nadava ( $v d$. natāre)

natāre: nadar

nölle: não querer: $2 .^{a} \mathrm{p} . \mathrm{pl} . \mathrm{do}$ pret. perf. ind. nōluistis

paulō: pouco

paulō post: pouco tempo depois perferre: sofrer

imperativo perfer, perferte

petěre $(+\mathrm{a}(\mathrm{ab})+\mathrm{abl}$. de pess.): pedir (a alguém) petēns, entis: que pede ( $v d$. petĕre)

petǔlans, antis: atrevido

posĭtus, a, um: posto de parte

timōre posĭtō: perdido o receio

prōferre: apresentar

caput prōferre: deitar a cabeça de fora

quia: já que

rana, ae: rã

ridēns, entis: que ri; rindo; a rir

saeuus, a, um: feroz

singŭlus, a, um: um $a$ um

stagnum, i: lago

statim: imediatamente; logo

subĭtō: subitamente

tač̀tē: sem barulho

talis, e: tal; abl. sing. tali

terrēre: atemorizar

tigillum, i: pedaço de madeira

timor, ōris: medo

tum: então

tunc: então

uadum, i: vau; pl. água

uidēns, entis: vendo: uidēns rēgem esse tigillum: ao ver que o rei era um pedaço de madeira

uorāre: devorar 


\section{CONJUGAÇÃO VERBAL}

I. possum, potes, posse, potui 'poder' (vd. p. 149).

INDICATIVO

\section{Presente}

possum

potes

potest

possŭmus

potestis

possunt

potĕram

potěras

potěrat

poterāmus

poterātis

potěrant
CONJUNTIVO

possim

possis

possit

possimus

possitis

possint

Pretérito imperfeito

possem

possēs

posset

possēmus

possētis

possent

Futuro imperfeito

potěrō

potěris

potěrit

poterĭmus

poterítis

potěrunt

Pretérito perfeito

potui

potuisti

potuit

potuřmus

potuistis

potuērunt

potuĕrim

potuĕris

potuĕrit

potuerimus

potuerítis

potuěrint 
Pretérito mais-que-perfeito

potuĕram

potuĕras

potuissem

potuĕrat

potuissēs

potuerāmus

potuisset

potuerātis

potuissēmus

potuĕrant

potuissētis

potuissent

\section{Futuro perfeito}

potuĕrō

potuĕris

potuĕrit

potuerĭmus

potuerĭtis

potuerint

\section{Infinitivo}

Presente

Perfeito

posse

potuisse

II. ferō, fers, ferre, tuli, latum 'levar; trazer'

\section{Presente do indicativo}

Voz activa

Voz passiva

ferō

feror

fers

ferris

fert

fertur

ferĭmus

ferĭmur

fertis

feriminni

ferunt

feruntur

\section{Imperativo}

fer

ferte 
N.B.:

As restantes formas da flexão deste verbo são regulares. Assim:

Imperfeito do indicativo

ferēbam

ferēbar

Futuro imperfeito

feram

ferar

ferēs

ferēris

Pretérito perfeito do indicativo

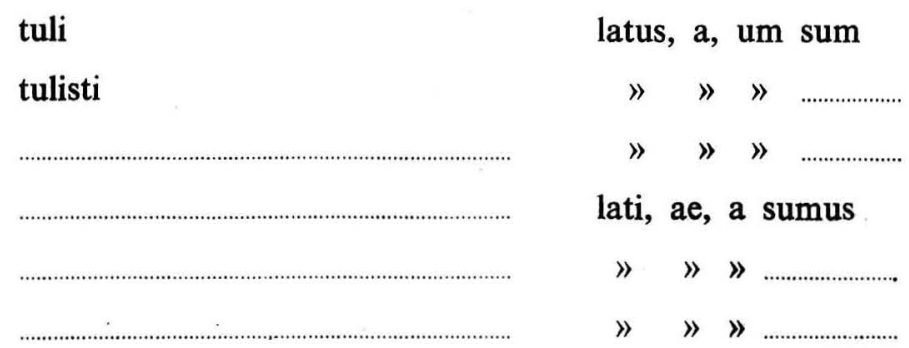


Pretérito mais-que-perfeito do indicativo

tulěram

latus, a, um eram

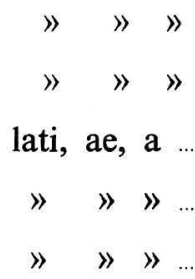

Futuro perfeito

tulěrō

latus, a, um erō

tulěris

1 $\gg$,
lati, ae, a
$\gg \quad \gg$
$\gg \quad \gg$.

Presente do conjuntivo

feram

ferar

feras

ferāris

Imperfeito do conjuntivo

ferrem

ferrer

ferrēs

ferrēris 
Pretérito perfeito do conjuntivo

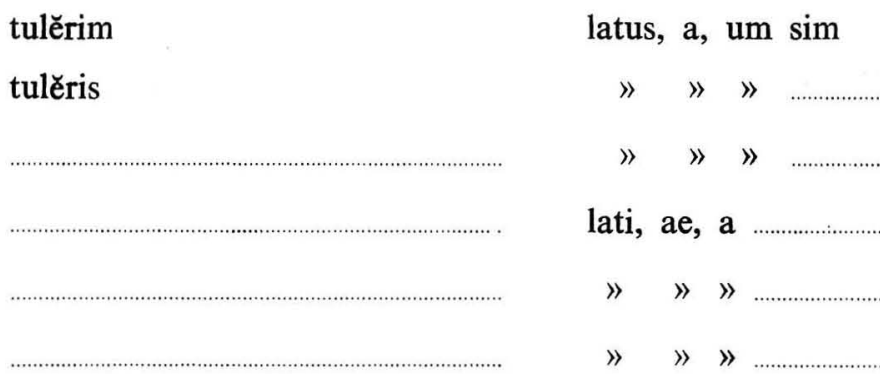

\section{Pretérito mais-que-perfeito do conjuntivo}

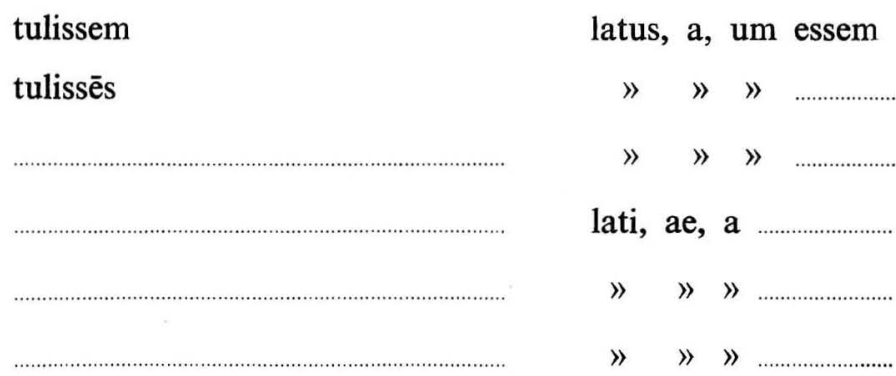

\section{Participios}

\section{Presente}

ferēns, entis
Passado

latus, a, um
Futuro

latūrus, a, um
Gerúndio
Ac. ferendum
G. ferendi
D. ferendō

Ab. ferendō
Gerundivo

ferendus, a, um 


\section{Infinitivo}

Presente

ferre 'levar; trazer'

ferri 'ser levado; ser trazido'
Perfeito

tulisse 'ter levado; ter trazido'

$\left.\begin{array}{l}\text { latum, am, um } \\ \text { latōs, as, a }\end{array}\right\} \begin{aligned} & \text { esse 'ter sido levado; } \\ & \text { ter sido trazido' }\end{aligned}$

\section{Futuro}

$\left.\begin{array}{l}\begin{array}{l}\text { latūrum, am, um } \\ \text { latūrōs, as, a }\end{array}\end{array}\right\}$ esse 'haver de levar; haver de trazer' latum iri 'haver de ser levado; haver de ser trazido'

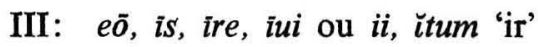

INDICATIVO

is

it

imus

itis

eunt
CONJUNTIVO

Presente

\section{Pretérito imperfeito}

ibam

irem

ibas

irēs eam

eas

eat

eāmus

eātis

eant 


\section{Futuro imperfeito}

ibō

ibis

\section{Pretérito perfeito}

i(u)i

i(u)isti

i(u)it

i(u)ĭmus

i(u)istis

i(u)ērunt i(u)ěrim

i(u)ěris

i(u)ĕrit

i(u)erĭmus

i(u)erìtis

i(u)ěrint

Pretérito mais-que-perfeito

i(u)ěram

i(u)ĕras i(u)issem

i(u)issēs

\section{Futuro perfeito}

i(u)ěrō

i(u)ěris

i(u)ěrit

i(u)erĭmus

i(u)erǐtis

i(u)ĕrint 


\section{Particípios}

Presente

iēns, euntis

Gerúndio

Ac. eundum

G. eundi

D. eundō

Ab. eundō
Passado

itus, a, um
Futuro

itūrus, a, um

\section{Infinitivo}

Presente
ire

Gerundivo

eundus, a, um

Perfeito

i(u)isse

\section{Futuro}

$\left.\begin{array}{l}\text { itūrum, a, um } \\ \text { itūrōs, as a }\end{array}\right\}$ esse

\section{Imperativo}

i

ite

IV. uolō, uis, uelle, uolui 'querer'; nōlō, nōn uis, nōlle, nōlui 'não querer'; malo, mauis, malle, malui 'preferir'

INDICATIVO

\section{Presente}

$\begin{array}{lll}\text { uolō } & \text { nōlō } & \text { malō } \\ \text { uis } & \text { nōn uis } & \text { mauis } \\ \text { uult } & \text { nōn uult } & \text { mauult } \\ \text { uolŭmus } & \text { nōlŭmus } & \text { malŭmus } \\ \text { uultis } & \text { nōn uultis } & \text { mauultis } \\ \text { uolunt } & \text { nōlunt } & \text { malunt }\end{array}$




\section{Pretérito imperfeito}

uolēbam

nōlēbam

malēbam

Futuro imperfeito

uolam

nōlam

uolēs

uolet

uolēmus

uolētis

uolent

Pretérito perfeito

uolui

nōlui

uoluisti .

uoluit

uoluĭmus

uoluistis

uoluērunt

Pretérito mais-que-perfeito

uoluěram

nōluĕram

uoluĕras

uoluěrat

uoluerāmus

uoluerātis

uoluěrant malui

maluěram

malam
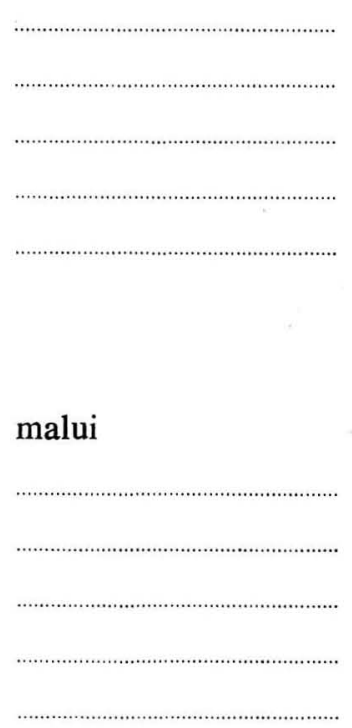


\begin{abstract}
uoluěrō
uoluěris

uoluěrit

uoluerĭmus

uolueritis

uoluĕrint
\end{abstract}

CONJUNTIVO

\section{Presente}
uelim
uelis
uelit
uelïmus
uelitis
uelint

uellem
uellēs
uellet
uellēmus
uellētis
uellent

\section{Pretérito imperfeito}

nōlim

malim

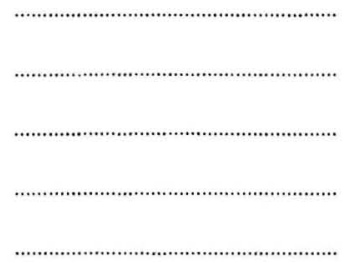

nōllem

mallem

malim maluěrō
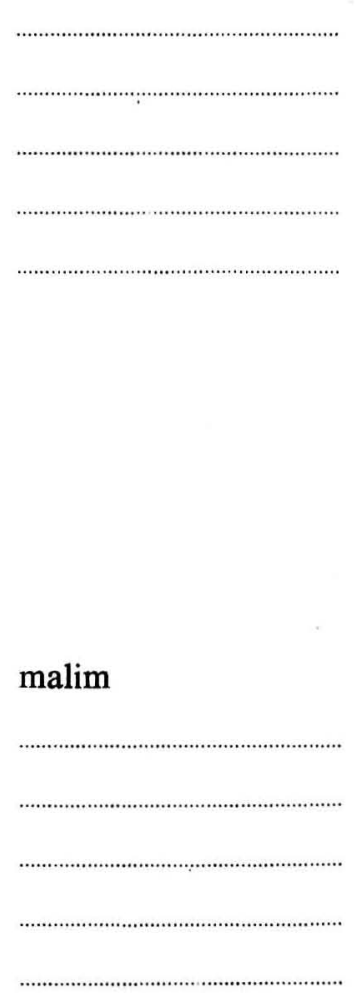

\section{2}


Pretérito perfeito

uoluĕrim

uoluĕris

uoluĕrit

uoluerĭmus

uoluerĭtis

uoluěrint

\section{Pretérito mais-que-perfeito}

\author{
uoluissem \\ uoluissēs \\ uoluisset \\ uoluissēmus \\ uoluissētis \\ uoluissent
}

nōluissem

maluissem

\section{Participio presente}

uolēns, entis

nōlēns, entis

malēns, entis

\section{Infinitivo}

Presente

uelle

nōlle

malle

Presente
uelle
nōlle
malle

Imperativo

nōli
nōlite

maluěrim

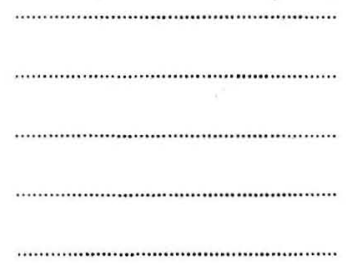


V. fiō, fis, fiëri, factus sum 'ser feito; tornar-se'

Este verbo serve de passiva a facère nos tempos do sistema do presente, dos quais apenas se usam os seguintes:

INDICATIVO

toō

fis

fit

fimus

fitis

fiunt

fiēbam

fiēbas

fiēbat

fiēbāmus

fiēbātis

fièbant
CONJUNTIVO

\section{Presente}

fiam

fias

fiat

fiāmus

fiātis

fiant

Pretérito imperfeito

fiĕrem

fiěrēs

fiěret

fierēmus

fierētis

fièrent

Futuro imperfeito

$\begin{array}{ll}\text { fiam } & \text { fiēmus } \\ \text { fiēs } & \text { fiētis } \\ \text { fiet } & \text { fient }\end{array}$

N.B.:

Os tempos do sistema do perfeito são formados com o particípio passado de facère (factus, $a$, um) e o auxiliar esse. Assim, por exemplo:

Pretérito perfeito

\begin{tabular}{|c|c|c|c|}
\hline actus & $a$ & um & sun \\
\hline$»$ & » & 》 & es \\
\hline » & » & 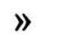 & est \\
\hline facti, & ae, & a & mus \\
\hline " & 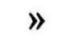 & " & estis \\
\hline 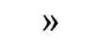 & Ir & $»$ & int \\
\hline
\end{tabular}

\begin{tabular}{|c|c|c|c|}
\hline actus & $\mathrm{a}$ & um & $\sin$ \\
\hline 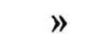 & 》 & » & sis \\
\hline " & 》 & $»$ & sit \\
\hline facti, & ae, & a & simus \\
\hline " & " & $»$ & sit \\
\hline " & » & $»$ & sint \\
\hline
\end{tabular}




\section{Pölus ille 1 tragoedus}

Fama est histriōnem in Graeciā fuisse nōbilissǐmum, qui et 2 gestus uenustāte et uōcis claritudĩne cētěris antestāret ${ }^{3}$. Is histriō, cui nōmen erat Pōlus, tragoedias poētārum nōbilium scitē atque asseuērātē actitāuit ${ }^{4}$. Eius filius unǐcē amātus dē uitā dēcessit. Pater, postquam eum èluxit, rediit ad quaestum artis. Eō temporre 5 Athēnis 6 Electram Sophŏclis actūrus erat. Electra autem in hac fabŭlā urnam quasi cum 7 Orestis fratris cineribus gestans complōrat commiserāturque interītum eius existimātum. 8 Igĭtur Pōlus, lugŭbri habìtu Electrae indūtus, 9 urnam $\bar{e}$ sepulcrō tulit et, quasi Orestis cinĕrēs amplexus, oppleuit theatrum, nōn simulacris neque imitamentis, sed luctu atque lamentis uēris et spirantǐbus.

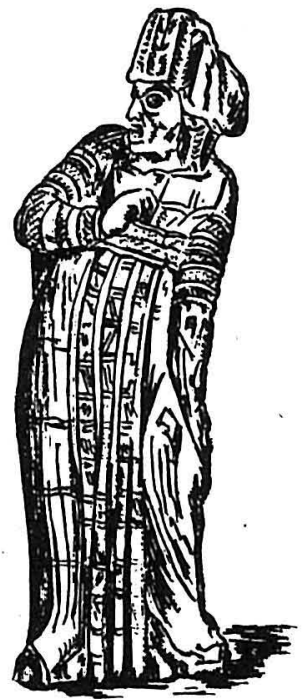

1 ille: enfático; traduza por 'o célebre; o famoso'.

2 et... et 'não só... mas também; não apenas... senão também'.

3 Note o conjuntivo numa oração relativa dependente de uma infinitiva.

4 actitåre 'representar com frequência; costumar representar': verbo frequentativo (note o sufixo -ităre) de agère (supino actum) 'agir; desempenhar um papel numa peça de teatro'.

5 Note a ausência de preposição no complemento circunstancial de tempo em que.

6 Complemento circunstancial de lugar onde: note a ausência da preposição com os nomes de cidades.

7 quasi cum: traduza por 'que se supunha conter' (à letra: 'como se com [= contivesse $]$ '): vd. nota seguinte.

8 existimåtum 'suposta [morte]': de facto, Orestes, irmão de Electra, não tinha morrido, como esta supunha. Em breve ele surgirá em cena para se dar a conhecer à inconsolável irmã.

9 . É sabido que, no teatro grego antigo, os papéis femininos eram representados por homens. Outro tanto acontecia no teatro clássico japonês e nos tempos de Shakespeare, por exemplo. 


\section{VOCABULÁRIO}

agĕre: conduzir; representar (uma peça de teatro)

supino actum

amātus, a, um: amado

amplexus, a, um [+acusat.]: $a b r a-$ çado a

antestāre [+ dat.]: estar à frente de; superar

asseuērātē: apaixonadamente; com toda a verdade; com realismo

cētěrus, a, um: restante cētěri, ōrum: os demais

cinis, ěris: cinza (= restos mortais)

claritūdō, İnis: clareza; sonoridade

commiserāri (verbo depoente): lamentar; lastimar

complōrāre: lamentar; deplorar ; chorar

dēcēděre: retirar-se

pret. perf. do ind. dēcessi dē uitā dēcēděre: morrer

Electra, ae: Electra (filha de Agamémnon e de Clitemnestra, e irmã de Ifigénia e de Orestes: vd. pp. 173-174, capp. V-VI) ēlugēre: chorar; findar o luto pret. perf. do ind. èluxi fabŭla, ae: história; fábula; peça de teatro

gestāre: transportar

gestus, us: gesto; movimento do corpo

habrtus, us: veste; trajo histriō, ōnis: actor

igitur: portanto

imitamentum, i: imitação

indūtus, a, um: vestido

interitus, us: morte

lamenta, ōrum: lamentações; gemidos

luctus, us: dor; sofrimento

lugŭbris, e: de luto

nōbīlis, e: conhecido; famoso; célebre

opplēre: encher completamente

Orestēs, is: Orestes

Pōlus, i: Polo (nome de homem) quaestus, us: profissão

quaestus artis: o exercício da profissão, da arte

quasi: como se; como que redire: regressar

scitē: habilmente; com arte

simulacrum, i: imagem; imitação ;

fingimento

Sophǒclēs, is: Sófocles

spirans, antis: sincero; natural tragoedus, i: actor trágico uenustas, ātis: elegância uērus, a, um: verdadeiro unǐcē: particularmente; entranhadamente

uōx, uōcis: voz

urna, ae: urna (vaso de gargalo estreito e bojo amplo, para água, votos, dinheiro, etc.); urna cinerária (i. e., vaso onde se guardavam as cinzas dos corpos incinerados) 


\section{ORAÇÕES INTERROGATIVAS INDIRECTAS}

Ao contrário das orações interrogativas directas (vd. pp. 27, 29 e 69 sqq.), as indirectas têm sempre o verbo no conjuntivo.

EXEMPLOS:

Dic 1 mihi (Diz-me) $\left\{\begin{array}{l}\text { ubi sit agricǒla. } \\ \text { quō ambŭlet mulier. } \\ \text { unde ueniat seruus. } \\ \text { quā iter faciant mater et filia. }\end{array}\right.$

Nesciō (Não sei) $\left\{\begin{array}{l}\text { quot (quantos: indeclinável) uiri sint in pictūrā. } \\ \text { quota (que) hōra sit. } \\ \text { quis sit in tabernā. } \\ \text { quid dicas. } \\ \text { qui homo }(=\text { que homem; que espécie de homem: } \\ \text { vd. p. 109, b) ) esset. } \\ \text { quod templum aedificauěrint. }\end{array}\right.$

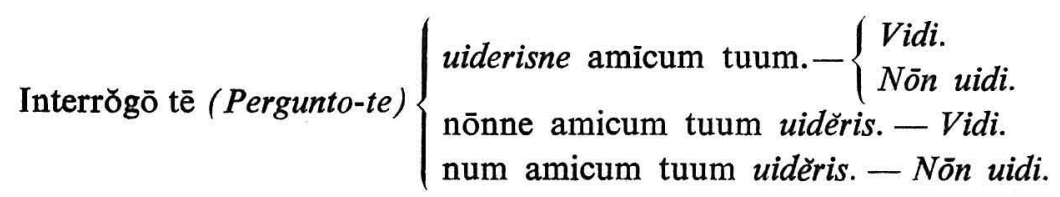

Quaerō 2 dē uōbis (Pergunto-vos) $\left\{\begin{array}{l}\text { ueniātis an maneātis. } \\ \text { ueniātisne an maneātis. } \\ \text { utrum ueniātis an maneātis. } \\ \text { ueneātisne necne }{ }^{3} .\end{array}\right.$

1 Imperativo de dicère: dic, dicĭte.

2 O verbo quaerō, is, ěre, quaesiui ou ii, quaesitum 'perguntar' constrói-se com ablativo, regido de $a(a b), \bar{e}(e x)$ ou $d \bar{e}$, da pessoa a quem se pergunta.

3 necne 'ou não': só nas interrogativas indirectas. 
E X E R C Í C I O S :

Ele perguntou-me onde estava o pai.

Digam-nos (= dizei-nos) para onde vão (= ides).

Eles disseram-lhe donde tinham vindo (uenire; pret. perf. do ind. uēni).

$\mathrm{Tu}$ perguntaste-lhes por onde tencionavam ir (vd. p. 239 sqq.).

Não sei (nescire) se Lúcio quer ficar (manēre) em casa (= locativo: domi).

Não sabíamos se eles queriam ficar em casa ou sair (exire). 1.

2.

3.

Eu quero saber (scire) se António está ou não em casa (= está em casa ou não). 
Nós tencionamos investigar (inuestigāre: vd. p. 239 sqq.) por onde [é que] ele foi (ire).

Vocês não queriam saber para onde [é que] nós tinhamos levado (ferre) os livros (liber, ri).

Paulo preferia saber se vocês estavam a estudar (= estudáveis: studère).

Digam-me quem esteve no átrio.

Vocês sabiam que espécie de homens (uir, uiri) eles eram.

Eles hão-de preferir (= preferirão) não saber que espécie de mulher ela é.

Eu queria saber de que tens medo (= que coisa receias: metuère).

Tu perguntaste-lhes que monumentos (monumentum, $i$ ) tinham visto (uisere: pret. perf. do ind. uisi) em Roma (= locativo). 
N U M E R A IS

\begin{tabular}{|c|c|c|c|}
\hline $\begin{array}{l}\text { NUME- } \\
\text { RAÇÃo } \\
\text { ÁRABE }\end{array}$ & $\begin{array}{l}\text { NUMERAÇÃo } \\
\text { ROMANA }\end{array}$ & CARDINAIS & ORDINAIS \\
\hline 1 & I & unus, -a, -um & primus, -a, -um \\
\hline 2 & II & duo, duae, duo & $\begin{array}{l}\text { secundus, -a, -um ou alter, -ěra, } \\
\text {-èrum }\end{array}$ \\
\hline 3 & III & trēs, tria & tertius, -a, -um \\
\hline 4 & IIII, IV & quattuor & quartus, -a, -um \\
\hline 5 & $\mathbf{V}$ & quinque & quintus, $-a$, -um \\
\hline 6 & VI & sex & sextus, $-a,-u m$ \\
\hline 7 & VII & septem & septimmus, -a, -um \\
\hline 8 & VIII & octō & octãuus, -a, -um \\
\hline 9 & VIIII, IX & nouem & nōnus, -a, -um \\
\hline 10 & $\mathbf{x}$ & děcem & decimus, -a, -um \\
\hline 11 & XI & unděcim & undecĭmus, \\
\hline 12 & XII & duoděcim & duodecimus \\
\hline 13 & XIII & trēdēcim & tertius decImus \\
\hline 14 & XIV & quattuorděcim & quartus decĭmus \\
\hline 15 & $\mathbf{X V}$ & quinděcim & quintus decĭmus \\
\hline 16 & XVI & sēděcim & sextus decimus \\
\hline 17 & XVII & septemděcim & septilmus decimus \\
\hline 18 & XVIII & duodẽuiginti & duodẽuicēsimus \\
\hline 19 & XIX & undẽuiginti & undeuuič̃simus \\
\hline 20 & $\mathbf{X X}$ & uiginti & uicēš̌mus \\
\hline 21 & XXI & $\begin{array}{l}\text { unus (-a, -um) et uiginti } \\
\text { ou uiginti unus }\end{array}$ & $\begin{array}{l}\text { primus et uicesimus ou uicesimus } \\
\text { primus }\end{array}$ \\
\hline 22 & XXII & $\begin{array}{l}\text { duo }(-a e,-0) \text { et uiginti ou } \\
\text { uiginti duo }\end{array}$ & $\begin{array}{l}\text { alter et uicesimus ou uicesimus } \\
\text { alter }\end{array}$ \\
\hline 28 & XXVIII & duodētriginta & duodētricēsǏmus \\
\hline 29 & XXIX & undētriginta & undētricēsīmus \\
\hline
\end{tabular}




\begin{tabular}{|c|c|c|c|}
\hline $\begin{array}{l}\text { NUME- } \\
\text { RAÇÃo } \\
\text { ÁRABE }\end{array}$ & $\begin{array}{c}\text { NUMERAÇÃO } \\
\text { ROMANA }\end{array}$ & CARDINAIS & ORDINAIS \\
\hline 30 & $\mathrm{XXX}$ & triginta & tricēsĭmus \\
\hline 40 & XXXX, XL & quadraginta & quadragesimus \\
\hline 50 & $\mathbf{L}$ & quinquaginta & quinquagesimus \\
\hline 60 & LX & sexaginta & sexagesimus \\
\hline 70 & LXX & septuaginta & septuagesimus \\
\hline 80 & LXXX & octōginta & octōgesimus \\
\hline 90 & $\mathrm{LXXXX}, \mathrm{XC}$ & nơnaginta & nōnagesimus \\
\hline 100 & C & centum & centesimus \\
\hline 101 & CI & centum (et) unus & centesimuş primus \\
\hline 102 & CII & centum (et) duo & centesimus alter \\
\hline 200 & $\mathrm{CC}$ & ducenti, -ae, -a & ducentesimus \\
\hline 300 & $\mathrm{CCC}$ & trecenti, -ae, $-\mathrm{a}$ & trecentesimus \\
\hline 400 & $\mathrm{CCCC}, \mathrm{CD}$ & quadringenti, -ae, -a & quadringentesimus \\
\hline 500 & D & quingenti, -ae, -a & quingentesimus \\
\hline 600 & DC & sescenti, -ae, $-\mathrm{a}$ & sescentesimus \\
\hline 700 & DCC & septingenti, -ae, -a & septingentesimus \\
\hline 800 & DCCC & octingenti, -ae, -a & octingentesimus \\
\hline 900 & $\mathrm{DCCCC}, \mathrm{CM}$ & nōngenti, -ae, -a & nōngentesimus \\
\hline 1.000 & $\mathbf{M}$ & mille & millesimus \\
\hline 1.234 & MCCXXXIV & $\begin{array}{l}\text { mille ducenti triginta quat- } \\
\text { tuor }\end{array}$ & $\begin{array}{l}\text { millesimus ducentesimus trice- } \\
\text { simus quartus }\end{array}$ \\
\hline 2.000 & MM & duo milia & bis millesimus \\
\hline
\end{tabular}




\section{I - Numerais cardinais :}

Dos numerais cardinais apenas se declinam:

a) os três primeiros;

b) os números das centenas, excepto centum;

c) e o numeral milia.

DECLINAÇÃo:

a)

N. unus una unum duo duae duo trēs triă Ac. unum unam unum duōs duās duo trēs triă G. unius duōrum duārum duōrum trium

D. uni duōbus duābus duōbus tribus

Ab. unō unā unō duōbus duābus duōbus tribus

\section{b)}

Os numerais de ducenti, ae, $a$ a nōngenti, ae, $a$ declinam-se como o plural dos adjectivos da primeira classe (vd. p. 47 sqq.).

c)
Ab. miliă
Ac. miliă
G. milium
D. miľrbus
Ab. milibus

OBSERVAÇס̃ES:

1. Como duo, declina-se também ambō, ambae, ambō 'ambos'.

2. Milia 'milhar; mil' é um substantivo que se constrói com genitivo:

Duo milia militum (= dois milhares de soldados $=$ dois mil soldados). 


\section{II - Numerais ordinais :}

Os ordinais são adjectivos da primeira classe e têm um emprego semelhante ao dos ordinais portugueses, com as seguintes diferenças:

a) indicação da hora :

$$
\operatorname{ho} r \bar{a}\left\{\begin{array}{l}
\operatorname{prim} \bar{a}=\text { às sete horas } \\
\text { secund } \bar{a}=\text { às oito horas } \\
\text { tertiā }=\text { às nove horas } \\
\ldots \ldots \ldots \ldots \ldots \ldots \ldots \ldots \ldots \\
\operatorname{sext} \bar{a}=\text { ao meio-dia } \\
\ldots \ldots \ldots \ldots \ldots \ldots \ldots \ldots \\
\text { duodecimm } \bar{a}=\text { às dezoito horas }
\end{array}\right.
$$

b) indicação do ano:

annō millesīmō nōngentēsĭmō octōgēsĭmō septīmō $=\mathrm{em} 1987$.

OBSERVAÇÃO:

Em latim usa-se primus, a, um para indicar o primeiro de vários, e prior, prius para o primeiro de dois. De modo semelhante, secundus $=$ o segundo entre vários, e alter $=0$ segundo de dois (vd. p. 67).

Assim, por exemplo, os 12 cantos da Eneida de Virgílio são designados, em latim, por: liber primus, liber secundus, liber tertius, etc. Porém, se uma determinada obra constar apenas de dois volumes, então dir-se-á: liber prior, liber alter.

\section{N.B.:}

a.C.: ante Christum (natum) $=$ antes de (o nascimento de) Cristo p.C.: post Christum (natum) $=$ depois de (o nascimento de) Cristo 


\section{ORIGEM DOS SINAIS NUMÉRICOS ROMANOS}

\section{I - Os dígitos.}

Do mesmo modo que as crianças das nossas escolas, os povos primitivos serviam-se, naturalmente, dos dedos da mão para contar: daí a designação de números dígitos. Assim, também, entre os Romanos: $\mathrm{I}=u m$ (dedo); $\mathrm{II}=$ dois (dedos); etc.

O contorno da mão aberta, com os seus cinco dedos, sugeriu o sinal $\mathrm{V}=$ cinco; a junção de $\mathrm{VV}$, em posição inversa, deu origem a $\mathrm{X}=$ dez.

\section{II - Os sinais $\mathrm{L}, \mathrm{C}, \mathrm{M}$ e $\mathrm{D}$}

Estes sinais provêm de letras do alfabeto grego (de tipo ocidental), que, através dos Etruscos, está também na origem do alfabeto latino.

Assim:

$$
\begin{aligned}
\Psi(=\mathrm{kh})>\boldsymbol{U}>\mathrm{L} & =50 \\
\Theta(=\mathrm{th})>\Theta>\mathrm{C} & =100 \\
\Phi(=\mathrm{ph})>\Phi>\boldsymbol{D} & >\mathrm{M}=1.000 \\
& >\mathrm{D}=500
\end{aligned}
$$

Por aqui se vê claramente que os sinais $\mathbf{C}$ e $\mathbf{M}$ nada têm que ver, em princípio, com as letras iniciais, respectivamente, de CENTVM e MILLE, como à primeira vista se poderia pensar. Contudo, é evidente que, no seu desenho final, esses mesmos sinais acabaram por ser identificados com as letras $\mathbf{C}$ e $\mathbf{M}$.

Tal confusão, porém, já se não verificou com $\mathbf{L}$ e $\mathbf{D}$, sinais que em nada se assemelham à letra inicial de QVINQVAGINTA e QVINGENTI. 


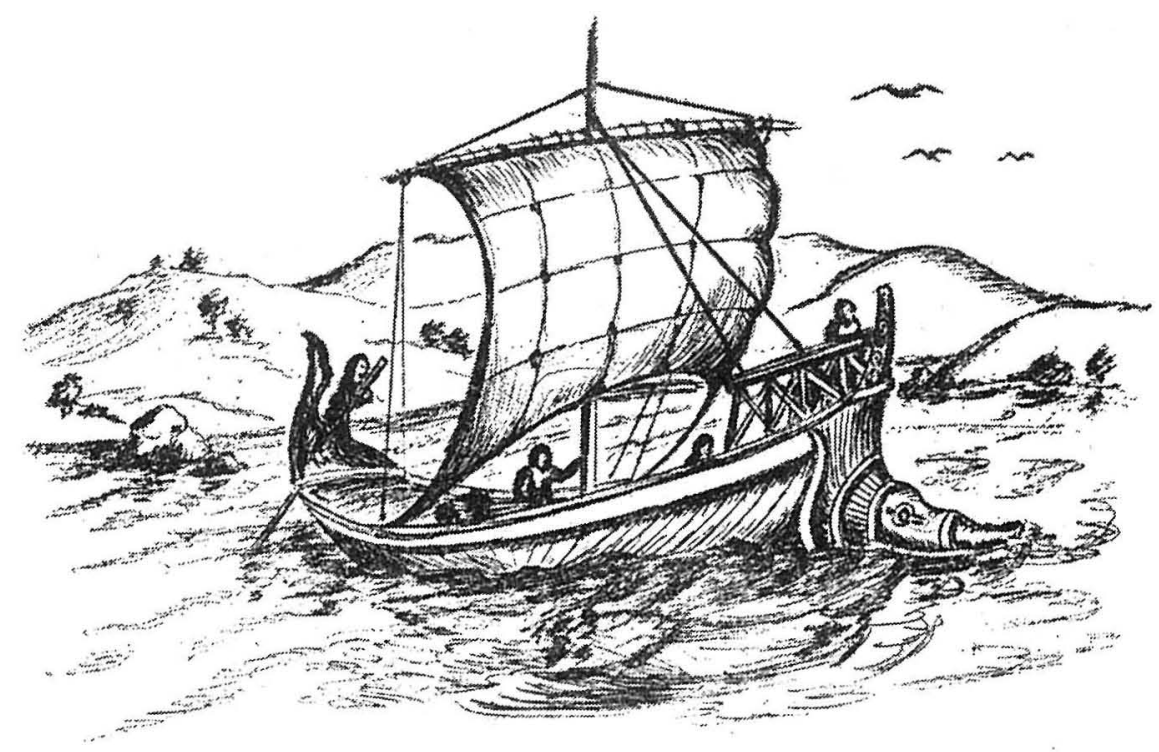

\section{Aenēas in Italiam appellit}

Postquam Aenēas è Trōiānis ōris soluit, multa per maria nauigāuit, multas per terras errāuit, sed per omnēs labōrēs periculaque semper Italiam petēbat, ubi dei nouam patriam ei prōmisěrant. Tandem post longas aerumnas terrā 1 marique passas ad ōstia Tibĕris appŭlit. Tunc illic incolēbant Aboriğnēs, quibus 2 imperābat rēx Latīnus. Huic rēgi ${ }^{3}$ unǐca erat filia, nōmǐne Lauinia, ōracŭlis destināta externō maritō, matris tamen uoluntāte Turnō Rutulōrum rēgi prōmissa.

Aenēas autem, ubi primum in terram ēgressus est, ōratōrēs mittit ad Latīnum rēgem, qui nōn modo in socium admīsit, sed ōracŭli 4 memor etiam in matrimōnium ei dedit filiam. Quā dē causā Turnus bellum Aenēae Latinōque rēgi indixit.

Cum aequō Marte 5 bellum aliquamdiu traherētur, Turnus cum Aenēā singulāri certamǐne dimicāre statuit et occidǐtur. Pace facta, Aenēas nouum oppǐdum condǐdit, quod ab uxōris nōminne Lauinium appellăuit, mōrēs suōs deōsque in Latium intŭlit. 
Aenēae post mortem filius Iulus, cui nômen Ascanius 6 quoque fuit, nouam urbem Albam Longam condǐdit, unde post multōs annōs uēnērunt Rōmŭlus Remusque. Rōmǔlus condĭtor Rōmae fuit: ita Rōmāni ab urbe Trōia originnem trahēbant.

\section{Dẽ Rōmŭli Remique pueritiā}

Post Iulum, in urbe Albā Longā unděcim rēgnauērunt rēgēs; tandem Numitōri 7 rēgnanti frater Amulius rēgnum ēripuit et eius filiam Rheam Syluiam fēcit uirğ̌nem uestālem 8. Haec autem gemǐnum partum ēdưdit Rōmŭlum Remumque, quōs Amulius irātus iussit 9 in Tiběrim mitti. Forte, ut Titus Liuius narrat, 10 super ripas fluuius effūsus erat lēnǐbus stagnis nec appropinquāre serui, qui puěrōs portābant, ad iustum flumĭnis cursum potuērunt. Ităque in proxīmā alluuiē eōs exposuērunt. Vastae tum in iis locis sōlitudīnēs erant. Fama est, cum 11 fluitantem alueum, in quō exposĭti erant puěri, tenuis aqua in siccō dēstituisset, lupạ̦ 12 sitientem ex montǐbus, qui circa

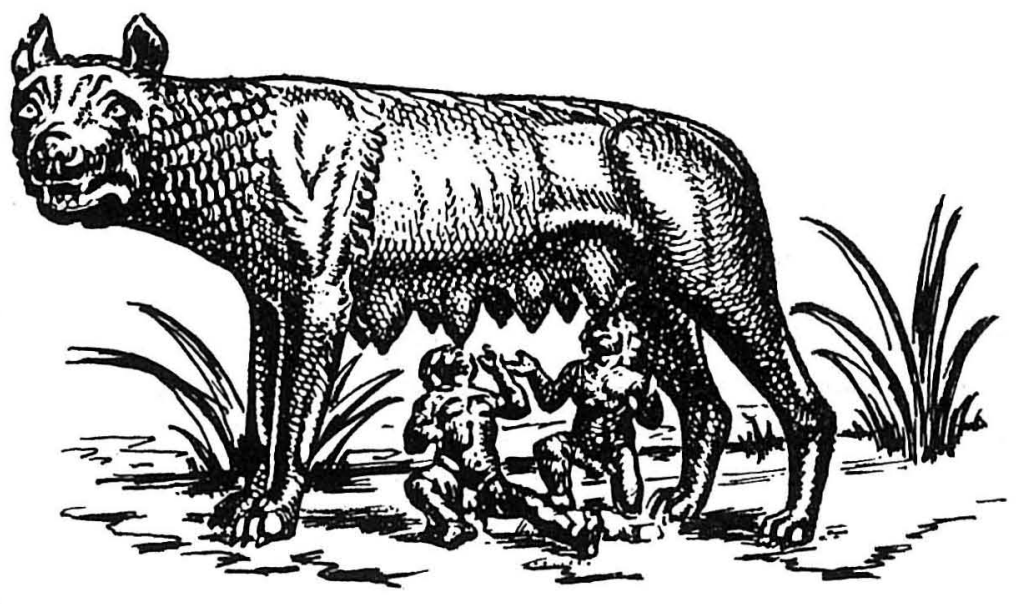

sunt, ad puerilem uagitum cursum flexisse et submissas infantǐbus praebuisse mammas; sic eōs inuenisse Faustŭlum suarium et in casam tulisse, ut 13 Larentia uxor ēducāret. Ita genĭti, ita ēducāti, cum primum adolēuit aetas, Rōmŭlus Remusque, origine cognitā, Amulium occidērunt ac Numitōri auō rēgnum dedērunt. 


\section{Rômŭlus Rômae condìtor}

Ita 14 Numitōri Albānā rē 15 permissā, Rōmŭlum Remumque cupido 16 cēpit in iis locis, ubi expositi ubique èducāti erant, urbis condendae. Quoniam ${ }^{17}$ gemǐni essent et fiĕri 18 nullō modo posset ut dēcernerētur uter nouae urbis condǐtor futūrus esset 19, Rōmŭlus «Dii», inquit, «auguriis 20 legent utri 21 nōmen nouae urbi dandum sit.» Ităque mane in monte Palatinō Rōmŭlus, Remus Auentīnō ad inaugurandum 22 templa 23 capiunt. Remus in caelō uultŭrēs sex primus uidet; deinde Rōmŭlus duplǐcem numĕrum. Quō auguriō laetus Rōmŭlus statim iubet 24 urbem condi; sed Remus 25 inuidiae plēnus fertur nouōs transiluisse murōs dicēns: «Sic hostēs hōs murōs tam humīlēs transilient.» Tum Rōmŭlus gladiō dēstricto irātus fratrem interfēcit adiciēns: «Sic deinde moriētur quicumque alius 26 transiliet moenia mea!» Ita sōlus potitus 27 est imperiō Rōmŭlus; condǐta urbs conditōris nōmǐne appellāta est Rōma. ${ }^{28}$

\section{NOTAS}

1 terrā marique 'por terra e por mar; em terra e no mar': note o ablativo.

2 Dativo pedido pelo verbo imperāre 'ser senhor; ter o domínio': quibus imperäbat rēx Latinus 'que eram governados pelo rei Latino'.

3 huic regi: dativo de possuidor (vd. pp. 77, 2, e 180,1).

4 oracŭli: genitivo pedido por memor 'que se lembra; lembrado'. a parte'.

5 aequō Marte 'com vantagens iguais [na guerra]; sem vantagens de parte

6 Grande é a discrepância em redor do nome do filho de Eneias na tradição seguida pelos historiadores e pelos poetas. Para Virgílio, Julo e Ascânio eram a mesma pessoa: filho de Eneias e Creúsa, acompanhou o pai após a destruição de Tróia (vd. p. 223), auxiliou-o na luta contra Turno, sucedeu-lhe no trono de Lavínio e, depois, fundou Alba Longa. Segundo outros, entre os quais o historiador Tito Lívio, Ascânio e Julo são dois filhos de Eneias, nascidos Julo de Creúsa e Ascânio de Lavínia. Segundo outros, ainda, Julo era filho de Ascânio e entrou em luta com Sílvio, filho de Eneias e de Lavínia. 
7 Numitöri rêgnanti frater Amulius règnum èripuit 'a Numitor, que reinava, [seu] irmão Amúlio arrebatou o poder; o rei Numitor foi deposto por seu irmão Amúlio que...'.

8 Ao fazer de Reia Sílvia uma sacerdotisa de Vesta, a intenção de Amúlio era, evidentemente, impedir que ela viesse a ter descendência que um dia pudesse reclamar o trono do avô, como de facto aconteceu.

9 Vd. p. 217.

10 Ab Vrbe condita, 1, 2-7, onde se fala dos acontecimentos deste capítulo e do seguinte, e de que nos servimos largamente, embora com compreensíveis alterações.

11 cum [+ conjuntivo]: oração causal.

12 lupam sitientem: acusativo, sujeito da oração infinitiva dependente de fama est (vd. p. 212); pela mesma razão, vd., mais abaixo, Faustǔlum suarium.

13 ut [+ conjuntivo]: oração final.

14 'Assim', isto é, com a morte de Amúlio e o restabelecimento de Numitor no trono (vd. final do cap. anterior).

15 Albāna rēs 'a governação de Alba Longa'.

16 cupidō... urbis condendae 'o desejo de fundar uma cidade': vd. p. 248.

17 Quoniam [+ conjuntivo] 'como; visto': oração causal.

18 fièri nullō modō posset ut [+ conjuntivo] '[e como] fosse impossível' : vd. p. 274.

19 Vd. pp. 239 e 277 sqq.

20 auguriis 'por meio de augúrios; com augúrios'.

21 utri 'por qual dos dois': dativo, agente da perifrástica passiva (vd. p. 254).

22 ad inaugurandum 'para tomar os augúrios': vd. p. 236 sq.; cf. port. inaugurar.

23 templa caperre 'escolher como ponto de observação'. Templum era, na linguagem augural, o espaço celeste, delimitado pelo áugure por meio do lituus ('bastão recurvado'), dentro do qual se devia observar (contempläri: note o parentesco etimológico com templum) o voo das aves. O plural templa é referido, no presente caso, aos dois observadores, Rómulo e Remo.

24 Vd. p. 217.

25 Remus... fertur 'Remo é dito; diz-se que Remo': construção pessoal.

26 quicumque alius 'qualquer outro que'.

27 potîri imperiō [ablativo] 'apoderar-se do poder'.

28 Esta etimologia, transmitida por T. Lívio (Ab Vrbe condita, I,7), não é aceite pela critica moderna. O processo foi certamente inverso: de Roma (designação - acaso etrusca - de um pequeno afluente do Tibre, o Rumo ou Rúmon, que corria na área do Foro) se extraiu o nome Rómulo, para explicar aos Antigos a origem do nome da cidade, por meio de um herói fundador. 


\section{VOCABULÁRIO}

Aborigĕnēs, um: Aborígenes adicĕre: acrescentar

admittěre: admitir

in socium admittěre: aceitar como aliado

adolēscěre: crescer

cum primum adolēuit aetas: quando [ Rómulo e Remo] atingiram a idade adulta. aerumna, ae: sofrimento; provação aetas, ātis: idade

aliquamdiu: durante bastante tempo

alluuiēs, èi: inundação; cheia

proxĭma alluuiēs: o lugar inundado que se encontra mais próximo

alueus, ei: selha; gamela appellāre: chamar appropinquāre: aproximar-se auus, i: avô

casa, ae: cabana; choupana certāmen, ìnis: luta; combate singulāre certāmen: combate singular; duelo

cognĭtus, a, um: conhecido conděre: fundar condítor, ōris: fundador cum [+ indicativo]: quando cum primum: logo que cupīō, ǐnis: desejo

cupīdō alĭquem capit: $o$ desejo apodera-se de alguém cursus, us: percurso; corrente (de um rio)

dēcerněre: decidir

dēstinātus, a, um: destinado dēstituĕre: abandonar; deixar dēstrictus, a, um: desembainhado dimicāre: lutar duplex, ǐcis: duplo duplex numěrus: $o$ dobro èdĕre: dar à luz gemĭnum partum ēdĕre: dar à luz dois filhos gémeos

ēducāre: criar effundĕre: espalhar; na pass. espalhar-se; derramar-se super ripas effundi: inundar as margens

ēgrědi [verbo depoente]: sair part. pass. ègressus, a, um; in terram ēgrědi: desembarcar ēripěre: arrebatar; tirar expōněre: expor; abandonar pret. perf. do ind. exposui externus, a, um: estrangeiro Faustǔlus, i: Fáustulo flectěre: dobrar cursum flectěre: mudar de direcção; encaminhar-se

fluĭtans, antis: que flutua; $a$ flutuar; flutuante

forte: por acaso geminnus, a, um: gémeo genĭtus, a, um: gerado gladius, ii: espada humĭlis, e: pouco elevado; rasteiro; baixo illic: lá; nesse lugar incolěre: habitar indicěre: proclamar bellum alicui indicěre: declarar guerra a alguém 
infans, antis: que não fala: pueritia, ae: infância criança

inferre: levar para; introduzir

interficěre: matar

inuenire: encontrar; descobrir

ita: assim

ităque: por isso

iustus, a, um: normal; regular

Larentia, ae: Larência

Latinus, i: Latino (nome de homem)

Latium, ii: Lácio (região da Itália)

Lauinia, ae: Lavínia

Lauinium, ii: Lavínio (cidade do Lácio)

legěre: escolher

lēnis, e: suave; calmo

mamma, ae: mama; teta

mane: de manhã

mittěre: lançar; enviar

mōs, mōris: costume

occiděre: matar

ōra, ae: litoral; praia

ōrātor, ōris: embaixador; emissário

orĭgō, ĭnis: origem

originnem trahěre: tirar a sua origem; descender

ōstium, ii: porta; embocadura (de um rio); $f o z$

passus, a, um: sofrido; suportado

permissus, a, um: confiado

petěre [+ acus.]: dirigir-se para

praebēre: oferecer; dar

submissas praebēre mammas:

dar de mamar; amamentar

primus, a, um: primeiro

primus uidet: é o primeiro a ver prōmittěre: prometer

part. pass. prōmissus, a, um

rēgnum, i: poder real

rēgnum alicui dare: pôr alguém no trono

Rutŭli, ōrum: Rútulos (povo do Lácio)

siccum, i: lugar seco; terra firme in siccō: em seco

sitiēns, entis: que tem sede;

sōlitūdō, ĭnis: solidão

uastae sōlitudǐnēs: lugares onde a solidão é total

soluĕre [subentenda-se ancŏram, funem, nauem]: levantar ferro; partir (por mar)

sōlus, a, um: só; sozinho

stagnum, i: lago; tanque; charco statim: logo; imediatamente statuěre: decidir suarius, ii: guardador de porcos submissus, a, um: abaixado tandem: por fim tenuis, e: delgado; pouco profundo; baixo

trahĕre: arrastar; na pass. prolongar-se

transilire: saltar por cima; transpor

pret. perf. transilui

Turnus, i: Turno

uagitus, us: vagido

uastus, a, um: despovoado

ubi [+ indicativo]: quando

ubi primum: logo que; mal

unde: donde

uoluntas, aatis: vontade

uter, ra, um: qual dos dois

genit do sing. utrius (3 géneros)

dat. do sing. utri (3 géneros)

uultur, ŭris: abutre 


\section{SEPTEM RŌMANŌRVM RËGĒS; \\ PRIMI CŌNSV̆LĒS; DICTATV̄RA}

\section{Sabinārum raptus et Rōmŭli apotheōsis}

Condĭtā ciuitāte ${ }^{1}$, Rōmŭlus primus Rōmanōrum rēx, multitudǐnem finitimōrum in ciuitātem ${ }^{2}$ recēpit; centūm ex seniōrǐbus ēēegit, quōrum ${ }^{3}$ cōnsiliō omnia agĕret: quōs ${ }^{4}$ senatōrēs nōmināuit propter senectūtem.

Tunc, cum uxōrēs ipse ${ }^{5}$ et popŭlus nōn habērent, ludōs ${ }^{6}$ ex industria 7 parat Neptūnō Equestri sollemnēs et ad eōs inuitat uicinas urbis Rōmae natiōnēs. Multi mortālēs conuēnērunt studiō etiam ${ }^{8}$ uidendae nouae urbis.

Iam Sabinōrum omnis multitūdō cum liběris ${ }^{9}$ ac coniugĭbus uenit et, dum deus concelebrātur, Rōmāna pubēs eōrum uirgĭnēs rapit. Quarē Sabini bellum Rōmānis indixērunt. Iam in media conualle 10 duōrum montium proelium commisěrant, cum 11 Sabīnae muliĕrēs, quarum ${ }^{12}$ ex iniuria bellum ortum erat, ausae 13 sē inter tēla uolantia inferre, patrēs uirōsque ōrant 14 ut bellum inter sē compōnant.

1 Vd. p. 162 sqq.

2 in ciuitatem 'para a cidade; na cidade': note a construção in + acusativo depois de um verbo de movimento ou de um verbo que, como aqui, implica ideia de movimento.

3 quorum ... ageret: oração relativa final (note o conjuntivo).

4 quos ... nominauit 'a eles (= àqueles) chamou-lhes; e deu-lhes o nome de': o pronome relativo no princípio de uma frase tem o valor de um demonstrativo.

5 ipse 'ele mesmo', isto é, Rómulo.

6 Vd. p. 47, OBSERVAÇÃo: traduza conjuntamente ludos ... sollemnes.

7 ex industria 'de propósito deliberado', isto é, 'com segundas intenções'. Neptuno Equestri 'em honra de Neptuno Equestre'.

8 studio etiam uidendae 'também com o desejo de ver': o que fez afluir a Roma grande número de povos vizinhos foi não apenas o convite para assistir aos Jogos Públicos, mas também (etiam) a curiosidade de ver a cidade recém-fundada. A propósito de uidendae, vd. p. 248 sqq.

9 Vd. p. 47, OBSERVAÇão.

10 in media conualle 'no meio de um vale'.

11 Conjunção temporal.

12 quarum ex iniuria 'do ultraje que lhes fora feito': quarum é um genitivo objectivo.

13 À letra: 'tendo ousado'.

14 orare + acusat. de pessoa + ut $(+$ conjuntivo $)$ 'pedir ou implorar a alguém que'. 
Pace facta 15, Rōmāni Sabinique ciuitātem unam ex duābus faciunt; rēgnum cōnsociant; imperium omne confěrunt Rōmam 16.

Immortalǐbus 17 èdĭtis operíbus, cum 18 Rōmŭlus ad 19 exercĭtum recēnsendum contiōnem habēret, subĭtō coorta tempestas cum magnō fragōre tonitribusque tam ${ }^{20}$ dēnsō rēgem operuit nimbō, ut cōnspectum eius contiōni abstulěrit. Et cum ${ }^{21}$ deinde in terris Rōmŭlus nōn esset, ad deōs transisse crēdĭtus ${ }^{22}$, cōnsecrātus est.

\section{Numa Pompilius, Tullus Hostilius et Ancus Marcius}

Deinde Rōmae per ternōs diēs 23 senatōrēs imperauērunt et, his rēgnantíbus 24 , annus unus complètus est.

Postea Numa Pompilius rēx creātūs est; qui bellum nullum quidem gessit, sed nōn minus ciuitāti, quam Rōmŭlus, prōfuit 25 . Nam et lēgēs Rōmānis morēsque cōnstituit, qui cōnsuētudĭne proeliōrum iam latrōnēs ac semibarbări putabantur; et annum dēscripsit in duodĕcim mēnsēs; et maxĭmē circa deōrum cultum occupātus infinìta Rōmae 26 sacra ac templa cōnstituit. Fēlicissǐmus Rōmanōrum 27 rēgum hab̆̌tus, supra 28 octōginta annōs natus morbō dēcessit, cum 29 trēs et quadraginta annōs rēgnauisset.

15 Vd. supra, nota 1.

16 Compl. circunstancial de lugar para onde: note a ausência de preposição com um nome de cidade; veja-se ainda supra, nota 2 .

17 À letra: 'dignas de imortalidade'; vd. supra, nota 1.

18 Conjunção causal (note, $o$ conjuntivo).

19 ad exercitum recensendum: vd. p. 248 sqq.

20 tam denso ... nimbo, ut ... abstulerit 'com uma nuvem tão densa, que os soldados reunidos em parada deixaram de o ver': note $u t+$ conjuntivo (oração consecutiva; abstulerit é o perfeito do conjuntivo de auferre 'tirar; impedir': vd. p. 267).

21 Vd. supra, nota 18: cum deinde in terris Romulus non esset "como a partir daquele momento Rómulo não mais tivesse sido visto na terra'.

22 ad deos transisse creditus 'julgou-se que ele fora admitido entre os deuses (à letra: que se mudara para junto dos deuses)'.

23 per ternos dies 'cada um durante três dias'.

24 Vd. p. 162 sqq.

25 Vd. pp. 149-150.

26 Locativo: 'em Roma'.

27 Romanorum regum: vd. p. 228.

28 supra octoginta annos natus 'com mais de oitenta anos'.

29 cum ... regnauisset 'como tivesse reinado; tendo reinado': vd. supra, nota 18. 
Huic successit Tullus Hostilius, qui, bellis reparātis ${ }^{30}$, Albānōs et alias uicinas urbis Rōmae natiōnēs uicit. Vrbem ampliāuit, adiectō Caeliō monte ${ }^{31}$. Cum ${ }^{32}$ triginta duōbus annis rēgnauisset, fulmǐne ictūs, cum domō sua arsit.

Post hunc, Ancus Marcius, Numae 33 ex filia nepōs, suscēpit imperivm. Contra Latīnōs dimicāuit; Auentinnum montem ciuitāti adiēcit, et Ianicŭlum; Ostiam ${ }^{34}$ ciuitātem supra mare sextō decǐmō milliariō ab urbe Rōmā condǐdit. Vicēsǐmō quartō annō imperii, morbō periit.

\section{Priscus 35 Tarquinius et Seruius Tullius}

Deinde rēgnum Priscus Tarquinius accēpit. Hic numĕrum senatōrum duplicāuit; circum 36 Rōmae 37 aedificāuit, ludōs 38 Rōmānōs instituit. Vicit idem etiam Sabīnōs, qui Rōmānis bellum intulěrant ${ }^{39}$, et nōn parum agrōrum ${ }^{40}$, sublātum iisdem, urbis Rōmae territōriō adiunxit; primusque 41 triumphans Vrbem intrāuit. Murōs fēcit,

30 Vd. p. 162 sqq.

31 Vd. nota anterior.

32 Vd. supra, nota 29.

33 Numae ex filia nepos 'neto de Numa [Pompilio] por parte de uma filha [deste]'.

34 A cidade de Óstia, na foz do Tibre (cf. supra mare 'à beira mar'), servia de porto a Roma.

35 Tarquínio o Prisco, isto é, o Antigo: cf. infra, cap. IV, Tarquínio o Suberbo.

36 Isto é, o Circus Maximus, primeiramente construído em madeira, e só muito mais tarde transformado em magnífico monumento por César.

37 Vd. supra, nota 26.

38 Os Jogos Romanos teriam sido, de facto, instituídos por Tarquínio o Prisco, como o afirma também o historiador Tito Lívio. A sua duração, primeiramente limitada a um dia, foi progressivamente aumentada até dezasseis; a sua realização só teria sido anual a partir do séc. IV a. C.: vd. p. 47, obSERvação.

39 Vd. p. 264 sqq.

40 non parum agrorum 'não pequena quantidade das [suas] terras; uma boa parte das [suas] terras': note o genitivo partitivo dependente do advérbio parum. Poderá omitir-se na tradução a expressão sublatum iisdem 'tirada aos mesmos' que vem a seguir.

41 primusque ... intrauit 'e foi o primeiro a entrar em Roma com honras de triunfo' (note a maiúscula do substantivo Vrbs, isto é, a 'cidade por excelência; Roma': cf. o título deste livro). O verbo intrare é transitivo, por isso se constrói com acusativo: cf. intrare atrium 'entrar no átrio', p. ex.

O triumphus era um grandioso cortejo, com o qual se celebrava a entrada em Roma de um general vitorioso. Chegado ao Capitólio, aí se agradecia aos deuses 
et cloācas; Capitōlium inchoāuit. Tricēsĭmō octāuō imperii annō, per 42 Anci filiōs occisus est, rēgis eius, cui ipse successěrat.

Post hunc, Seruius Tullius suscēpit imperium, geň̌tus 43 ex nōbřli fēminna, captiua tamen et ancilla. Fama est ei etiam tum puerŭlō dormienti circa caput flammam ēmicuisse. Hoc prōdigium Prisci Tarquinii rēgis uxor Tanăquil admirāta, Seruium in modum filii ēducāuit et ad rēgium fastigium ēuexit. Hic quōque Sabīnōs subēgit; montēs trēs, Quirinālem, Viminālem, Esquilīnum, Vrbi 44 adiunxit; fossas circa murum duxit. Primus omnium cēnsum ordināuit, qui adhuc per orbem terrārum incognĭtus erat. Sub eō 45 , Rōma, omnibus 46 in cēnsum dēlātis, habuit 47 capĭtum octōginta trēs milia ciuium Rōmanōrum, cum his, qui in agris erant. Occisus est 48 quadragēšmmō quintō imperii annō, scelěre geněri sui Tarquinii, filii eius rēgis, cui ipse succēssěrat, et filiae suae, quam Tarquinius habēbat uxōrem ${ }^{49}$, cum 50 supra octōginta annōs uixisset, ut dicǐtur ${ }^{51}$.

as vitórias alcançadas. Era constituído por animais ornamentados para os sacrifícios, pelos prisioneiros de guerra, magistrados, músicos, carregadores de despojos e maquetas das cidades conquistadas. Por fim, rodeado dos oficiais e soldados, vinha o carro do general triunfador. Este era revestido com uma túnica de púrpura bordada de estrelas de ouro, calçado de sandálias douradas; nas mãos, um ceptro de marfim, e na cabeça, uma coroa de louros; junto dele, no carro ou a cavalo, viam-se os filhos.

42 per Anci filios 'por instigação dos filhos de Anco [Márcio]'.

43 genitus 'que era filho'. Segundo a tradição, Sérvio Túlio era filho de uma mulher nobre, mas cativa, que servia em casa de Tarquínio. Designado para lhe suceder por uma chama que teria brilhado sobre o seu berço, acabou por se tornar genro do próprio rei.

44 Cf. supra, nota 41.

45 sub eo 'durante o seu reinado'.

46 omnibus in censum delatis 'após o recenseamento geral': vd. supra, nota 1.

47 habuit $\ldots$ in agris erant '[Roma] contou com uma população de oitenta e três mil cidadãos (à letra: oitenta e três mil cabeças de cidadãos romanos), incluindo os moradores dos campos'. Note o genitivo capitum dependente de milia: vd. p. 282 , ao fundo.

48 A história da morte de Sérvio Túlio, aqui simplificada, ter-se-ia passado do seguinte modo: as suas duas filhas, ambas chamadas Túlias, do nome do pai, tinham casado com dois filhos de Tarquínio o Prisco. Uma, a boa, era mulher do mau Tarquínio, a outra, a má, casara com o bom Tarquínio. Esta envenenou o marido e convenceu o cunhado a matar a mulher. Seguidamente, o mau Tarquínio lançou o sogro por uma janela, e a cruel Túlia fez passar o carro em que se encontrava por cima do corpo do seu próprio pai.

49 Vd. p. 168 sqq.

50 Vd. supra, notas 28 e 29.

51 ut dicitur 'segundo se diz'. 


\section{Lucius Tarquinius Superbus 52}

L. Tarquinius Superbus, septĭmus atque ultĭmus rēgum ${ }^{53}$, Volscōs (quae gēns ${ }^{54}$ ad Campaniam euntǐbus nōn longē ab Vrbe est) uicit; Gabiōs 55 ciuitātem et Suessam Pometiam subēgit; cum Tuscis pacem fēcit; et templum Ioui 56 in Capitōliō aedificāuit. Postea Ardeam oppugnans ${ }^{57}$, in octāuō decǐmō milliariō ab Vrbe posǐtam ciuitātem, imperium perdĩdit. Nam cum filius eius nōbilissĭmam fēmǐnam Lucrētiam ${ }^{58}$, eamdemque pudicissimmam, Collatīni uxōrem, stuprasset ${ }^{59}$, Brutus ${ }^{60}$, parēns et ipse Tarquinii, populum concitāuit, et Tarquiniō adēmit imperium. Mox exerç̌tus quoque eum, qui 61 ciuitātem Ardeam cum ipsō rēge oppugnābat, relīquit ${ }^{62}$; ueniēns ad Vrbem rēx portis

52 Exemplo de um nome romano, constituído pelos três elementos que se tornaram de regra: Lucius (geralmente dado em abreviatura, como se vê a seguir), era o praenōmen ou nome individualizante; Tarquinius, o nōmen, era o gentilício ou nome de família ou gēns; Superbus era o cognōmen. Dois outros exemplos: C. (= Gaius Gaio: praenōmen) Iulius (= Júlio, isto é, membro da gēns Iulia: nōmen) Caesar (= César: cognōmen); M. (= Marcus Marco) Tullius (= Túlio: membro da gēns Tullia) Cicèrō (Cícero: cognōmen).

53 Genitivo partitivo: ultimus regum 'o último dos reis'.

54 quae gens ... ab Vrbe est 'povo situado a curta distância da Cidade (= de Roma), na estrada da (à letra: para os que se dirigem à; vd. p. 270, ao cimo) Campânia'.

55 Gabios ciuitatem (nominativo Gabii ciuitas) 'à cidade de Gábios': note que o nome da cidade é do plural: (vd. p. 47). Outros exemplos: Pompeii urbs 'a cidade de Pompeios'; Athenae urbs 'a cidade de Atenas'.

56 Ioui 'a Júpiter; em honra de Júpiter': vd. declinação na p. 101.

57 Ardeam oppugnans 'no cerco de Árdea (à letra: cercando ou ao cercar ou quando cercava Árdea)': Árdea, pátria dos Rútulos, situava-se a sul de Roma.

58 O dramático episódio da violação e suicídio de Lucrécia, mulher de Lúcio Tarquínio Colatino, aqui resumido, foi pormenorizadamente descrito pelo historiador Tito Lívio (I, 57.4-59.2) e tem sido fonte de inspiração para poetas (Ovídio, Fastos. 2.721-852; Shakespeare, The Rape of Lucrece) e músicos (Benjamin Britten, The Rape of Lucretia), entre outros. Para a tradução dos superlativos nobilissimam e pudicissimam, vd. pp. 229-230.

59 stuprasset $=$ stuprauisset, de stupräre 'atentar contra a honra de; desonrar; violar': note o conjuntivo na oração causal introduzida por cum.

60 Brutus, parens et ipse Tarquinii '[Lúcio Júnio] Bruto, se bem que (ele mesmo) parente do [rei] Tarquínio'.

61 exercitus..., qui ... oppugnabat 'o exército que, comandado pelo próprio rei, cercava a cidade de Árdea'.

62 reliquit 'abandonou[-o]: o complemento directo eum refere-se, evidentemente, a Tarquínio o Soberbo. 
clausis 63 exclūsus est. Cumque imperasset 64 annōs uiginti quinque, cum uxōre et liběris 65 suis fugit. Tandem exul Tuscŭli 66 cum uxōre, quae ciǔtas nōn longē ab Vrbe est, ibi 67 ultra nōnagēš̆mum annum in firmissǔma ualētudǐne dicǐtur peruēnisse.

Ita Rōmae ${ }^{68}$ rēgnātum est ${ }^{69}$ per septem rēgēs annis ducentis quadraginta tribus.

\section{Primi cōnsŭlēs: L. 70 Iunius Brutus, Tarquinius Collatinus et Valērius Publicŏla}

Hinc ${ }^{71}$ cōnsŭlēs coepēre prō unō rēge duo hac 72 causa creāri, ut si unus 73 malus esse uoluisset, alter eum, habēns 74 potestātem simǔlem, coercēret. Et placuit 75 , nē imperium longius quam annum unum habērent, nē 76 per diuturnitātem potestātis insolentiōrēs 77

63 portis clausis: à letra 'fechadas as portas' (vd. supra, nota 1); no entanto, poderá traduzir-se este ablativo absoluto por 'encontrou as portas [da Cidade] fechadas'.

64 imperasset $=$ imperauisset: cf. supra, nota 59.

65 Vd. p. 47, OBSERVAÇÃo.

66 Tusculi 'em (= na cidade de) Túsculo': locativo (cf. supra, nota 26). Túsculo era uma cidade do Lácio, não longe de Roma (quae ciuitas non longe $a b$ Vrbe est).

67 ibi ... dicitur peruenisse 'aí, segundo se diz (= segundo a tradição), atingiu uma idade superior a noventa anos, sempre de excelente saúde'.

68 Vd. supra, nota 26.

69 regnatum est: à letra 'reinou-se'; poderá, no entanto, traduzir todo este período por 'Assim, o poder foi exercido em Roma por sete reis durante duzentos e quarenta e três anos'.

70 Sobre esta abreviatura, vd. supra, nota 52.

71 Hinc consules coepere (= coeperunt $)$... duo ... creari 'A partir desta data (= desde a expulsão dos reis), foram criados (a letra: começaram a ser criados) dois cônsules'.

72 hac causa..., ut... 'por este motivo, a saber...': poderá, no entanto, traduzir toda esta expressão por uma simples conjunção final.

73 unus..., alter... 'um..., outro...': vd. p. 67.

74 habens (+ acusat.) 'munido de; investido de'.

75 placuit (v. impessoal), ne ... 'foi decidido [pelo senado] que ... não...' Note o conjuntivo (haberent) com ne.

76 Conjunção final negativa: note o conjuntivo (redderentur e essent).

77 Para a tradução deste comparativo, vd. p. 189. 
redderentur, sed ciuilès semper essent, qui 78 sē post annum scirent futurōs esse priuātōs. Fuērunt igitur cōnsŭlēs, annō primō post rēgēs exactōs, L. Iunius Brutus (qui maxĭmē ēgěrat ut 79 Tarquinius Superbus pellerētur), et Tarquinius Collatinus, maritus Lucretiae. Sed Tarquiniō Collatīnō statim sublāta dignĭtas est: placuěrat 80 enim nē quisquam in Vrbe manēret, qui Tarquinius uocarētur. Ergō, acceptō omni patrimōniō suō, ex Vrbe migrāuit, et locō ipsius factus est Valērius Publicŏla cōnsui.

\section{T. ${ }^{81}$ Larcius, dictātor primus}

Nōnō annō post rēgēs exactōs Rōmae cum per ${ }^{82}$ ludōs ab 83 Sabinōrum iuuentūte nōnnullae 84 raperentur muliěrēs, concursu homǐnum factō rixa ac prope proelium fuit, paruaque 85 ex rē ad rebelliōnem spectāre rēs uidēbātur. Super ${ }^{86}$ belli Sabini metum id quoque accessěrat, quod Octāuius Mamilius, gener Tarquinii Superbi, ad 87 iniuriam socěri 88 uindicandam, ingentem collēgěrat exercǐtum. In 89 hac tantārum exspectatiōne rērum sollič̌ta ciuitāte noua dignǐtas est creāta, quae dictatūra appellātur, maior 90 quam cōnsulāris. Sed

78 qui... scirent 'por saberem': oração relativa causal (note o conjuntivo).

79 Oração final: note o conjuntivo (pelleretur).

80 Vd. supra, nota 75. Sobre o ódio dos Romanos à família dos Tarquínios, vd. Tito Lívio, II, 2.

81 Sobre esta abreviatura (= Titus Tito), vd. supra, nota 52.

82 per ludos 'durante (a realização de) os Jogos Públicos': cf. supra, nota 6 e 38.

83 ab Sabinorum iuuentute 'pelos jovens sabinos': vd. pp. 84 e 38 sqq.

84 Note que em latim duas negativas dão uma afirmativa: nonnullus 'não nenhum = algum' (vd. p. 67).

85 paruaque ... uidebatur 'de um episódio sem importância de maior parecia que se iria chegar a uma situação de revolta': a propósito do significado de res, vd. p. 84 .

86 Super belli Sabini metum..., quod... 'Ao receio de guerra contra os Sabinos acrescia ainda o facto de...'

87 ad ... uindicandam: vd. p. 248 sqq.

88 Sobre este genitivo, vd. supra, nota 12 .

89 In hac ... ciuitate 'Visto a cidade (= os Romanos) estar profundamente preocupada com a ameaça de acontecimentos de tamanha gravidade': vd. p. 162 sqq. (sollicita ciuitate: ablativo absoluto) e supra, nota 85 (a propósito do significado de res).

90 maior quam consularis 'superior ao ( = com mais poderes do que o) cargo de cônsul'. 
quis 91 primum dictātor creātus sit, nōn 92 satis cōnstat. Veterrìmi 93 autem auctōrēs adfirmant dictatōrem Rōmae primum fuisse T. Larcium. Eōdem annō, etiam magister equĭtum factus est, qui 94 dictatōri obsequerētur. Sabīnis 95 autem creātus Rōmae dictātor eō magis, quod propter sē creātum crēdiděrant, metum incussit. Ităque lēgātōs dē 96 pace mittunt. Quibus 97 ōrantǐbus dictatōrem senatumque, ut ueniam errōris hominǐbus adulēscentǐbus darent, respōnsum, ignōsci 98 adulēscentǐbus posse, senǐbus nōn posse, qui 99 bella ex bellis serĕrent.

91 quis ... creatus sit: oração interrogativa indirecta (vd. p. 277 sqq.).

92 non satis constat 'não se tem bem a certeza'.

93 Veterrimi ... auctores: isto é, os mais antigos analistas (assim eram designados os autores que primeiro se ocuparam da história de Roma).

94 Oração relativa final: note o conjuntivo obsequeretur.

95 Sabinis autem ... metum incussit: à letra 'A criação do cargo de ditador, em Roma, suscitou tanto mais receio entre os Sabinos, quanto estes mesmos julgavam que tal cargo fora criado por sua culpa', isto é 'A criação da ditadura em Roma suscitou grandes receios entre os Sabinos, sobretudo, por pensarem serem eles mesmos os causadores dela'.

96 de pace 'acerca da paz', isto é 'para a obtenção da paz'.

97 Quibus orantibus..., ut... darent, responsum [sc. est]: à letra 'A eles (= aos emissários dos Sabinos), que pediam ao ditador [Tito Lárcio] e ao senado, que perdoassem aos jovens sabinos o seu erro (=o seu condenável procedimento), foi respondido que...' Vd. supra, nota 4. Note, ainda, a construção de orare + acusat. de pessoa $+u t+$ conjuntivo 'pedir a alguém que' (vd. supra, nota 14).

98 ignosci ... posse, ... non posse 'que aos jovens se podia perdoar, mas não aos mais velhos': sobre as orações infinitivas, vd. pp. 212 sqq. e 260 sq.

99 qui ... sererent 'por da guerra fazerem nascer a guerra': oração relativa causal (note o conjuntivo). 


\section{VOCABULÁRIO}

accēdĕre: juntar-se; acrescer pret. perf. do ind. accessi accipěre: receber; recolher rēgnum accipěre: subir ao trono

pret. perf. do ind. accēpi sup. acceptum

adfirmāre (ou affirmāre): afirmar ; dar como certo adhuc: até então adiicěre: acrescentar; juntar pret. perf. do ind. adiēci adimĕre: tirar; arrebatar pret. perf. do ind. adēmi adiungěre: juntar pret. perf. do ind. adiunxi admirāri : admirar ; espantar-se adulēscēns, entis: adolescente aedificāre: edificar; mandar construir

agěre: agir; tomar medidas; contribuir

alicuius cōnsilio omnia agĕre: seguir em todas as suas ações o conselho de alguém

pret. perf. do ind. ègi

Albāni, ōrum: os Albanos (habitantes de Alba Longa)

ampliāre: ampliar; alargar ancilla, ae: criada; escrava Ancus, i: Anco annus, $\mathrm{i}$ : ano apotheōsis, is: apoteose; deifi. cação appellāre: chamar
Ardea, ae: Árdea (cidade dos Rútulos)

ardēre: arder; (na passiva) ser consumido pelas chamas pret. perf. do ind. arsi

auctor, ōris: autor audēre (verbo semidepoente): ousar; atrever-se a; aventurar-se pret. perf. do ind. ausus sum Auentinus, i: Aventino (uma das sete colinas de Roma)

auferre: tirar; retirar

Brutus, i.: Bruto (nome de homem)

Caelius, ii: Célio (uma das sete colinas de Roma)

Campania, ae: Campânia (região da Itália a sul de Roma)

Capitōlium, ii: Capitólio (uma das sete colinas de Roma)

captiuus, a, um: cativo; prisioneiro (de guerra)

caput, Ĭtis: cabeça

causa, ae: causa; motivo

cēnsus, us: censo; recenseamento circa [+ acusat.]: à volta de; cerca de; em redor de circus, i: circo ciuilis, e: civil; simples; afável; modesto

ciuis, is: cidadão ciurtas, ātis: cidade ciuitātem unam ex duābus facĕre: reunir duas cidades numa só

cloāca, ae: esgoto

coepěre: começar pret. perf. do ind. coepi 
coercēre: conter; impedir

Collatinus, i: Colatino (nome de homem)

committěre: travar

pret. perf. do ind. commīsi complēre: encher; preencher

annum unum complëri: ser completado o espaço de um ano; durar um ano

compōnĕre: reunir

bellum compōněre: terminar a guerra; fazer a paz concelebrāre: celebrar; festejar concitāre: amotinar concursus, us: afluência; reunião condère: fundar

conferre: reunir; concentrar coniux, ŭgis: esposa; mulher cōnsecrāre: consagrar; considerar como divino cōnsilium, ii: conselho; opinião cōnsociāre: unir

cōnspectus, us : aspecto ; presença ; vista

cōnstāre: estar seguro

Constat (impess.): é certo; é evidcrite; é coisa assente cōnstituĕre: estabelecer; instituir ; criar

lēgēs mōrēsque instituĕre: criar leis e suavizar $(=$ civilizar) os costumes

cōnsuētūdō, ĭnis: hábito

cōnsuētūdō proeliōrum: hábitos de guerra; processos de combater

cōnsul, is: cônsul

cōnsulāris, e: consular (que diz respeito ao cônsul) contiō, ōnis: assembleia

ad exercittum recēnsendum contiōnem habēre: reunir $o$ exército em parada para lhe ser passada revista

conuallis, is: vale (fechado por todos os lados)

conuenire: reunir-se; afluir pret. perf. do ind. conuēni

cooriri (verbo depoente): nascer subĭtō tempestas coorta est: desencadeou-se de repente uma tempestade

creāre: criar ; eleger; nomear (para um cargo)

part. pass. creātus, a, um crēděre: acreditar; julgar

pret. perf. do ind. crēdĭdi

cultus, us: cultura; culto (religioso)

dăre: dar; conceder

dēcēděre: afastar-se; ir-se embora ; morrer

pret. perf do ind. dēcessi

dēferre: trazer; levar; contar; submeter

in cēnsum dēferre: submeter ao recenseamento

deinde: em seguida; depois dēnsus, a, um: denso; espesso; cerrado

dēscriběre: dividir dictātor, ōris: ditador dictatūra, ae: ditadura dignitas, ātis: dignidade; cargo dimicāre: combater diuturnĭtas, ātis: longa duração (do tempo) 
dormire: dormir

particípio do pres. dormiēns, entis: estando a dormir

ducěre: conduzir; construir; mandar construir

pret. perf. do ind. duxi

dum: enquanto

duplicāre: duplicar

èděre: produzir; realizar

immortalia ēděre opěra: levar a cabo obras inesqueciveis

èducāre: criar ; educar

alĭquem in modum filii èducāre: criar alguém como um filho

èligĕre: escolher

pret. perf. do ind. èlēgi

ēmicāre: surgir; brilhar

pret. perf. do ind. èmicui

eō (adv.): tanto

eques, îtis: cavaleiro

equester, tris, tre: equestre

ergō: portanto; por conseguinte error, ōris: erro; falta; desvario

Esquilīnus, i: Esquilino (uma das sete coinas de Roma)

etiam: ainda

ēuehĕre: elevar

pret. perf. do ind. ēuexi

excludĕre: expulsar; banir

exclūsus, a, um: part. passivo de excludĕre

exercǐtūs, us: exército; tropas

exigěre: expulsar

part. pass. exactus, a, um

exspectatiō, ōnis: expectativa

exsul, ŭlis: exilado; desterrado facěre: fazer; mandar fazer ou construir; criar; nomear ciuitātem unam ex duābus facĕre: reunir duas cidades numa só

pret. perf. do ind.: fēci

part. pass. factus, a, um

fama, ae:

Fama est [ + oração infinitiva]: é fama; diz-se

fastigium, ii: ponto culminante; altura; nivel social; categoria

fēminna, ae: mulher

finitĭmi, ōrum: os povos vizinhos firmus, a, um: firme; sólido; vigoroso; duradouro; constante

flamma, ae: chama

fossa, ae: escavação; fosso

fragor, ōris: ruido; estrondo; fragor

fugěre: fugir

fulmen, innis: raio

Gabii, ōrum: Gábios (cidade do Lácio)

gener, ěri: genro

genitus, a, um: particípio de gigněre gerĕre: fazer

pret. perf. do ind. gessi

gigněre: gerar; dar à luz

habēre: ter; (na passiva) ser tido; ser considerado

hinc: daqui; deste lugar; a partir deste momento homo, Ǐnis: homem

Hostilius, ii: Hostílio iam: já

Ianicŭlum, i: Janiculo (uma das sete colinas de Roma) 
icěre: ferir

fulmine ictus: atingido por um raio

ignōscěre: perdoar

immortālis, e: imortal; imorredouro; eterno

imperāre: dominar; governar; exercer o poder

imperium. ii: poder; governo inchoāre: começar; dar início à construção (de um edifício) incognĭtus, a, um: desconhecido incutěre: suscitar; causar pret. perf. do ind. incussi indicěre: declarar pret. perf. do ind. indixi inferre: levar contra

sē inferre: avançar bellum inferre: pegar em armas (contra); fazer a guerra (a alguém)

infinitus, a, um: infinidade ingēns, entis: enorme; numeroso iniuria, ae: insulto ; agravo; ofensa insŏlēns, entis: orgulhoso; arrogante

ităque: portanto; por essa razão inuitāre: convidar

Iunius, ii: Júnio

iuuentus, ūtis: juventude; mocidade; os jovens (sentido colectivo)

Larcius, ii: Lárcio (nome de homem)

Latini, ōrum: os Latinos (habitantes do Lácio)

latrō, ōnis: ladrão; salteador

lēgātus, i: enviado; embaixador; emissário

lēx, lēgis: lei locus, i: lugar

locō (+ genit): em vez de; em lugar de

longius (adv.): durante mais tempo; mais

Lucius, ii: Lúcio

Lucrētia, ae: Lucrécia (esposa de Tarquínio Colatino, considerada como modelo de virtude conjugal)

magister, ri: mestre; chefe ; comandante

Mamilius, ii: Mamilio (nome de homem)

manēre: permanecer; ficar; morar Marcius, ii: Márcio maritus, i: marido

maxĭmē: sobretudo; principalmente

mēnsis, is: mês

metus, us: medo; receio

migrāre: emigrar; partir

milliarium, ii: milha

minus: menos

nōn minus quam: não menos (do) que

mittěre: enviar

modus, i: maneira; modo

mōns, montis: monte

morbus, i: doença

mortālis, e: mortal

mortālēs, ium: homens; gente mōs, mōris: costume

mox: em breve mulier, ěris: mulher

multitūdō, ĭnis: multidão; grande número

multus, a, um: muito; numeroso; em grande número 
murus, i: muro; muralha (de uma cidade)

natiō, ōnis: nação; povo

natus, a, um (part. de nascor): nascido

nepōs, ōtis: neto

Neptūnus, i: Neptuno

nimbus, i: nuvem

nōbǔlis, e: nobre; de familia nobre

nōmināre: designar; chamar

Numa, ae: Numa

numĕrus, i: número

obsěqui (verbo depoente): obedecer; estar sob as ordens

occiděre: matar

part. pass. occīsus, a, um

occupāre: apoderar-se de

circa deōrum cultum occupā-

ri: ocupar-se com o culto dos deuses

Octauius, ii: Octávio

omnis, e: todo

operïe: cobrir; esconder; ocultar

oppugnāre: cercar

opus, ĕris: obra

ōrāre: pedir; rogar; implorar

part. pres. ōrans, antis

orbis, is: circulo

orbis terrārum: a Terra; o mundo

ordināre: instituir ; promover

orïri (verbo depoente): nascer;

ter origem; originar-se

pret. perf. do ind. ortus sum

parāre: preparar; organizar

parēns, entis: parente

parum: pouco

pater, ris: pai

patrimōnium, ii: património;

bens; haveres pax, pacis: paz

pacem facĕre: fazer $a$ paz

pellĕre: expulsar; banir

per (+ acusat.): por intermédio

de; em consequência de

perděre: perder

imperium perděre: perder $a$ coroa $(=o$ poder; $o$ mando)

pret. perf. do ind. perdídi

perīe: perecer; morrer

peruenire: chegar a; atingir

pret. perf. do ind. peruēni

placēre: agradar; parecer bem

pret. perf. do ind. placui

Pompilius, ii: Pompilio

pōněre: pôr ; situar; construir

part. passivo: positus, a, um

postea: a seguir; seguidamente;

depois; mais tarde

potestas, ātis: poder

primum (adv.): primeiramente;

em primeiro lugar; primeiro

primus, a, um: primeiro

primus omnium: $e$ ou foi o primeiro de todos

priscus, a, um: muito antigo; velho

Priscus, i: Prisco (=o Antigo)

priuātus, a, um: privado; particular

priuātus, i : um particular ; um simples cidadão (em oposição a magistratus).

prō (+ ablat.): em vez de prōdigium, ii: presságio; prodígio;

milagre

proelium, ii: combate

prope: quase 
propter [+ acusat.]: por causa de; devido a

pubēs, is: jovens (sent. colectivo); juventude

Publicŏla, ae: Publícola

pudicus, a, um: pudico; casto; virtuoso

puerǔlus, i: rapazinho

etiam tum puerŭlus: quando ainda era de tenra idade putāre: considerar; olhar como quarē: por isso

quidem: na verdade; efectivamente

Quirinālis, is: Quirinal (uma das sete colinas de Roma)

quisquam, quaequam, quidquam (e quicquam) ou quodquam: algum; alguém; alguma coisa quōque: também; por sua vez rapěre: raptar

raptūs, us: rapto

rebelliō, ōnis: rebelião; revolta recēnsēre: passar em revista recipěre: receber; admitir; acolher pret. perf. do ind. recēpi

redderre: tornar; transformar; na

v. pass. tornar-se

rēgius, a, um: de rei; real

rēgnāre: reinar ; governar ; exercer

o poder real

rēgnum, i: poder real; trono

rēgnum cōnsociāre: unir os [dois] reinos

relinquerre: abandonar

pret. perf. do ind. relīqui

reparāre: recomeçar

respondēre: responder

part. pass. respōnsus, a, um rēx, rēgis: $r e i$ rixa, ae: contenda; disputa

Sabinae, ārum: as Sabinas

Sabini, ōrum: os Sabinos

sacer, ra, rum: sagrado

sacra, ōrum: cerimónias religiosas

satis: suficientemente; bastante; bem

scelus, ĕris: crime; acto criminoso ;

perversidade; malvadez

scire: saber

semibarbărus, a, um: semibárbaro

semper: sempre

senātor, ōris: senador

senātus, us: senado

senectus, ūtis: velhice; idade avançada

senex, senis: velho; idoso

senior, ōris: ancião; velho

ex seniōríbus: dos (= dentre os) anciãos; entre os homens de idade

serěre: plantar; semear; gerar

Seruius, ii: Sérvio

simı̃lis, è: semelhante; mesmo

socer, ěri: sogro

sollemnis, e: solene

sollicǐtus, a, um: cheio de ansie-

dade; perturbado; alarmado

spectāre: olhar; estar voltado

para; tender para

statim: imediatamente; logo

studium, ii: aplicação; ardor; desejo

subigěre: submeter

pret. perf. do ind. subēgi

subǐtō: subitamente; de súbito

sublātūs, a, um: particípio de tollěre 
succēdĕre: suceder (= substituir alguém num cargo) pret. perf. do ind. successi

Suessa Pometia, ae: Suessa Pomécia (cidade dos Volscos)

super (+ arısat.): acima de; além de

superbus, a, um: altivo; orgulhoso; soberbo; arrogante suscipěre: encarregar-se de imperium suscipĕre: tomar $o$ poder; assumir o poder pret. perf. do ind. suscēpi tamen: todavia; contudo Tanăquil, ilis: Tanaquil tandem: por fim

tantus, a, um: tão grande; tamanho

Tarquinius, ii: Tarquinio tēlum, i: arma de arremesso; dardo

tempestas, ātis: tempestade

terni, ae, a (numeral distributivo): três para cada um; três a três territōrium, ii: território Titus, i: Tito tollěre: tirar; tomar tonĭtrus, us: trovão transire: passar; mudar-se infinitivo perfeito transiuisse ou transi(i)sse

triumphāre: triunfar; obter as honras do triunfo

Tullius, ii: Túlio

Tullus. i: Tulo

tum: então

tunc: depois disso; seguidamente
Tusci, ōrum: Tuscanos ou Etruscos (habitantes da Etrúria)

Tuscǔlum, i.: Túsculo (cidade do Lácio)

Valērius, ii: Valério

ualētūdō, ǐnis: saúde

uenia, ae: favor; indulgência; perdão

ueniēns, entis: part. do pres. de uenire

uenire: vir

ueterrimus, a, um superlativo de uetus, ěris: velho; antigo

uicinus, a, um: vizinho

uidēre: ver; observar; na pass. parecer

Viminālis, is: Viminal (uma das sete colinas de Roma)

uincěre: vencer

pret. perf. do ind. uici

uindicāre: vingar

uir, uiri: homem; marido

uirgō, ĭnis: donzela; mulher nova uiuěre: viver

pret. perf. do ind. uixi

unus, a, um: um; um só; um único uocāre: chamar

uolāre: voar

part. do pres. uolans, antis: que voa (ou voava)

Volsci, ōrum: Volscos (povo do Lácio)

urbs, is: cidade

uxor, ōris: esposa; mulher cum uxōrēs nōn habērent: como não tivessem mulheres (com quem casar) 


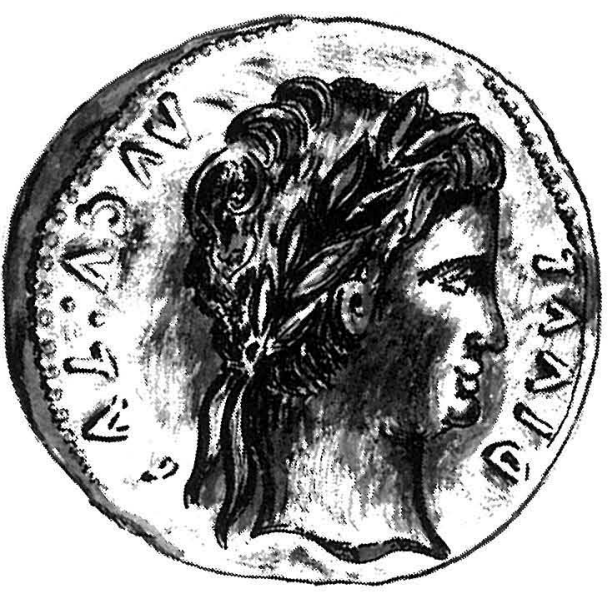

DIVVS AVGVSTVS

Moeda com a efígie de Augusto, primeiro imperador de Roma. 


\title{
I I PARTE
}

\author{
SOMNIVM \\ SEV \\ MIRIFICA NAVIGATIŌ 1
}

1 A história que se segue, apresentada sob a forma de um sonho, baseia-se,

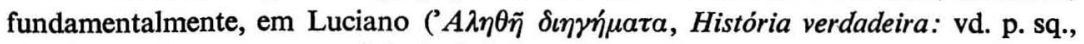
Anteloquium), mas com reminiscências de muitos outros autores, não apenas gregos e latinos, senão também de outras literaturas mais recentes. Sem os habituais vocabulários, ela poderá servir para que o estudante se familiarize com o dicionário de latim-português. 
(Página deixada propositadamente em branco) 


\section{A N T E L O Q I V M}

Mihi aliquandō ōtium agenti uēnit in mentem 1 ēnarrāre mirifĩcam nauigatiōnem Luciānō auctōre ${ }^{2}$, qui Graecē scripsit librōs duōs dē rēbus commenticiis ${ }^{3}$ quae in magnō mari ei ēuēnērunt. Scriptūrus sum igitur dē quibus 4 neque uidi, neque expertus sum; ad haec 5 , quae neque 6 sunt, neque fiĕri omninō possunt. Nullō modo igitur fidem illis adhibēre par, est 7 lēctōrēs; nam unum hoc certē uērum dicam ${ }^{8}$ : in hac historiā nihil ${ }^{9}$ nisi falsum.

1 À letra: 'A mim que estava, certa vez, desocupado veio[-me] à ideia'; traduza por: 'Estando eu, certa vez, desocupado, etc.'.

2 A letra: 'sendo Luciano o inspirador', isto é: '[uma espantosa viagem] inspirada em Luciano'.

3 dē rēbus commenticiis 'com as aventuras imaginárias'.

4 dē quibus 'sobre factos que'.

5 ad haec 'além do mais'.

6 quae neque 'trata-se de acontecimentos que nem'. lectores).

7 par est 'é conveniente; é justo; devem' + oração infinitiva (adhibēre...

8 unum... dicam 'uma única verdade eu certamente vou dizer: é que...'.

9 nihil: subent. est.

\section{Vbi dé Homęrō loquîtur}

Mē ōlim lentum in umbrā iam incipiēbat plurimmum taedēre 1 in herbā sedēre nec quidquam iucundum habēre quod facěrem. Semel et saepius 2 ocŭlōs coniciēbam in librum quem legēbam ${ }^{3}$. Sed ei 4 erant nec tabŭlae nec sermōnēs. "Quid adiŭuat 5 liber», mēcum reputābam, «in quō nullae sunt tabŭlae aut sermōnēs?»

Ităque cōgitābam (nempe ${ }^{6}$ ut lucidissǐmē potěram, nam tempestāte calīdā 7 torpēbam semisomnus!) num 8 opĕrae pretium esset 9 surgěre et

ut Homērus scribit 10, «Diuinum mihi secundum quiētem 11 uēnit insomnium", tam clarum, ut 12 nihil abesset a uēritāte: adeō post tantum tempŏris 13 speciēs 14 rērum uisārum in ocŭlis usque inhaeret, et sonus auditōrum 15 aurřbus insŏnat; tam manifesta erant omnia! 
Tum, cum 16 statuissem quid facěrem ${ }^{17}$, extemplō surrexi: mihi enim erat in animō 18 nauigāre ad alias terras.

1 Mē ölim ... taedēre 'Estando eu, certo dia, preguiçosamente estirado à sombra de uma árvore, começava já a sentir um grande aborrecimento por'. O verbo impessoal taedet está aqui construído com uma oração infinitiva (mē... sedère nec... habēre).

2 semel et saepius 'uma vez por outra'.

3 librum quem legēbam 'o livro que andava a ler ou que trazia em mãos'.

4 ei erant nec... nec... 'não tinha nem... nem': vd. pp. 77, 2 e 180, 1; tabŭla, ae 'gravura'; sermō, ōnis 'diálogo'.

5 Quid adiŭuat...? 'Que auxílio presta...?', isto é: 'Para que serve...?'

6 nempe ut... potèram 'é evidente que estava mesmo em condições de ter pensamentos lúcidos': a expressão é irónica, como sugere desde logo o emprego de nempe.

7 tempestāte calìdā 'com o calor que fazia'.

8 Oração interrogativa indirecta, dependente de cōgitäbam: 'se não...'

9 opèrae pretium esse 'valer a pena; ser melhor'.

10 Ilíada, II, 56-57.

11 secundum quiētem 'durante o [meu] sono'. dinante).

$12 u t+$ conjuntivo: oração consecutiva (note tam 'tão' na oração subor-

13 genitivo partitivo, dependente de tantum ('tanto de tempo; tanto tempo').

14. speciēs rērum uisārum 'a aparência das coisas vistas; tudo o que me foi dado ver'.

15 auditōrum 'das coisas ouvidas; do que ouvi': genit. do pl. neutro.

16 cum + conjuntivo: oração causal.

17 quid facèrem 'o que havia de fazer': oração interrogativa indirecta.

18 mihi... erat in animō 'tinha tomado a decisão': vd. supra, nota 4.

\section{De nauigatiōnis apparātu}

Quā dē causā navem (erat autem acatium ${ }^{1}$ ) firmāui ut ${ }^{2}$ ad magnam uiolentamque nauigatiōnem, magnam cibōrum cōpiam et aquae imposui; porrō aequalium ${ }^{3}$ quinquaginta mihi adiunxi, qui cōnsilium ${ }^{4}$ idem habēbant; ad haec ${ }^{5}$, gubernatōrem optĭmum magnā mercēde inductum ${ }^{6}$ adsciui 7 . Omníbus rēbus comparātis, nōbis 8 tamen in portu manendum fuit diēs septem ${ }^{9}$ : summa enim erat tranquillĭtas et sine uentō secundō 10 fiěri 11 nōn potěrat ut ancŏram tollerēmus. Octāuō autem diē 12 , cum uentus remissior 13 flauisset, ancŏram 14 tandem solưmus ex Olissipōnis portu et in occidentālem Oceănum dēlāti sumus 15 . 
1. acatium 'pequeno barco à vela, com uma tripulação de cerca de cinquenta homens; bergantim'.

2 ut ad [+ acusat.] 'como para'.

3 aequäles, ium 'companheiros da mesma idade'.

4 cōnsilium idem 'o mesmo desejo [que eu]'.

5 ad haec 'além disso' (à letra: além destas coisas).

6 inductus, $a$, um 'tendo sido convencido; depois de convencido': a forma do texto poderá traduzir-se por 'não sem primeiro o ter convencido'.

7 adsciui: pret. perf. do ind. de adsciscere 'contratar'.

8 nöbis... manendum fuit: vd. pp. 252-258.

9 acusativo de duração.

10 uentus secundus 'vento favorável; vento de feição'.

11 fièri non potèrat ut $[+$ conjunt.] 'não era possível'.

12 octāuō... diē: ablativo de tempo em que.

13 remissior: comparat. de superioridade sem segundo termo de comparação: 'bastante suave' (vd. p. 189).

14 ancöram soluère 'levantar a âncora; levantar ferro; zarpar': vd., um pouco antes, ancŏrain tollëre. Note que o verbo soluëre também se usa, sem o acusativo ancőram expresso, para significar 'partir [por mar]'.

15 pret. perf. do ind., na voz passiva, de dēferre 'levar': cf. pp. 264-268.

\section{Nauigatiōnis initium}

Adhuc 1 apparente aliquantum tellūre, mihi uēnit 2 in mentem illōrum uersuum:

Paulātim ${ }^{3}$ a nostrō collès montēsque recēdunt conspectu, nitidique Tagi iam linquĭtur unda; iam uix appārent montāna cacumīna Cintrae, lumĭna quis altis longum dēfixa tenēmus.

Maerēns sed patriis mēns nostra manēbat in öris, quae tot tam dulcis seruābant pignŏra amōris. Hic postquam tellus penĭtus diuisa recessit, occurrunt ocũlis caelum undique, et undique pontus.

Laeti ac fidentēs aequālēs 4 mei uel fabellas 5 narrābant uel concinēbant uel dormitābant, dum nauis nōn admŏdum uiolenter in altum prōuehebātur. Inter eōs autem erat Chrysostŏmus 6 quidam, uir glōriōsissǐmus 7 cui erat cognōmentum Lingulāca 8. Erat enim loquax ac cauillātor; sciēbat etiam fabŭlas multas ac facētas. Quārē unus ex aequalǐbus: « $\overline{\mathrm{O}}$ Lingulāca», inquit, «nōbis fabellam narra, nē 9 
obdormiscāmus.» Et Chrysostŏmus: «Date opĕram 10: fabellam dē muliěre quādam iurgiōsā, quae diabŏlō nupsit ${ }^{11}$, uōbis narrābō.»

1 adhūc... tellūre 'quando ainda divisávamos ao longe a terra'.

2 uenire in mentem 'vir à lembrança': note que a coisa lembrada vaj para genitivo.

3 Vd. Fr. Francisco de Santo Agostinho Macedo, Lusiadae, V, iii, uma das traduções latinas de Os Lusíadas. Para a correspondente estrofe dos versos acima citados vd. Os Lusiadas, V, iii.

4 Vd. supra, II, nota 3.

5 fabella, ae 'pequena história; anedota'.

6 Nome de origem grega, cujo significado original era 'o boca [stóma] de ouro [chrysós]', donde 'o eloquente; o bem-falante'.

7 'muito fanfarrão; fanfarrão dos quatro costados'.

8 cognōmentum Lingulāca 'a alcunha de Fala-Barato'.

9 ne + conjuntivo: oração final negativa.

10 dare operram 'prestar atenção'.

11 Vd. p. 168.

\section{Dē diabǒlō qui malam muliěrem duxit uxōrem 1}

Tum Chrysostŏmus sic incēpit: «Ōlim daemōn quidam in homĭnis speciem uersus ${ }^{2}$ apud ditissimmum ${ }^{3}$ uirum seruiēbat. Domǐnus, cui 4 ministerium serui atque industria perplacērent, ei dedit et filiam in matrimōnium et diuitias multas. Erat autem haec mulier mōrōsa admŏdum 5 et iurgiōsa, irarumque et molestiārum muliebrium per diem perque noctem scatēbat ${ }^{6}$. Quārē aliquot mensǐbus post matrimōnium diabǒlus, cui litigiōsa uxor nē 7 quiēscěre quidem permittēbat, ad socěrum adiit 8 et «Volō recēděre», inquit, «et in patriam meam redire.» «Quid hoc? 9 》 inquit socer. "Visne in patriam tuam redire? Nōnne bene tē habēs 10 apud mē? Sunt tibi 11 diuitiae multae; immō uērō etiam 12 uxōrem habēs filiam meam: nihil tibi dēest.» Et diabŏlus: "Volō tamen in patriam meam redire.» Tum socer: «Dic mihi saltem ${ }^{13}$, ubi sit patria tua.» Diabŏlus ait: «Patria mea est infernus, ubi nunquam tantas intemperiēs 14 in mē quantas hōc annō perpessus sum ${ }^{15}$ ab uxōre meā. Malō 16 in infernō esse quam amplius cum filiā tuā commorāri.»

His uerbis dictis, ex ocŭlis socěri uxōrisque ēuanuit. 17»

1 Vd. p. 168.

2 in hominis speciem uersus 'transformado na aparência de homem; em figura de gente'. 
3 Superlativo de diues, itis 'rico', que se poderá traduzir por 'podre de rico'. Para a tradução dos superlativos, vd. p. 229 sq.

4 cui... perplacērent 'porque muito lhe agradavam; muito agradado com': note o conjuntivo na oração relativa causal.

5 mōrōsa admōdum 'terrivelmente mal-humorada; de uma rabugice extrema'.

6 scatēre [+ genit.] 'jorrar': irarumque... scatēbat 'dia e noite ela fazia chover [sobre o marido] as afrontas e as inconveniências costumeiras nas mulheres'.

$7 n \bar{e} . .$. quidem 'nem sequer; nem mesmo'.

8 ad aliquem adire 'ir ter com alguém': vd. p. 268 sqq.

9 'Que é lá isso?; Mas que significa isto?; Mas que lembrança é essa?'.

10 bene sē habēre 'sentir-se bem; ser feliz'.

11 Vd. pp. 77, 2 e 18, 10.

12 immó uēeo etiam 'mais do que isso até'.

13 saltem 'ao menos'.

14 intemperiēs in alīquem 'os desmandos contra alguém'.

15 perpèti 'suportar': ab aliquō 'da parte de alguém'.

16 Vd. p. 270. Note que a expressão latina malle hoc quam id se deve traduzir por 'preferir isto a aquilo'.

17 ēuanēscère 'desaparecer; sumir-se; evaporar-se'.

\section{Terribł̉li procellā iactati 1}

Sic diem ${ }^{2}$ unum ac noctem uentō secundō $^{3}$ nauigaurmus: at mane postridiē cum sōle oriente et uentus increbuit et fluctus auctus est et caligō ingruit, nec fiĕri potěrat ut 4 uel uēlum contraherēmus. Tum uērō procella maxĭma in nauem prōrumpit:

Insequĭtur 5 clamorque uirum 6 stridorque rudentum.

Ëripiunt subŭtō nubēs caelumque diemque 7

nostris 8 ex ocŭlis; pontō nox incŭbat atra.

Intonuēre 9 poli et crebris micat ignibus aether, 10

praesentemque 11 uiris intentant omnia mortem.

Nam procella uentōrum ui stridēns 12

uēlum 13 aduersa ferit, fluctusque ad siderra tollit.

Franguntur rēmi; tum prōra auertit, et undis

dat 14 latus; insequĭtur cumülō praeruptus aquae mōns. 15

Ventō iğtur cum concessissēmus 16, tempestāte undeoctaginta diēs 17 iactati sumus: octōgēsimmō 18 uērō, cum sōl subǐtō illucēscěret, 
uidēmus 19 nōn procul insŭlam èminentem 20 ac siluestrem, quam 21 fluctus nōn asper circumsonābat: nam maior tempestātis pars resēděrat 22 .

1 iactāre 'sacudir; atormentar'.

2 diem unum ac noctem 'um dia e uma noite (= durante...)': acusativo de duração.

3 Vd. II, nota 10.

4 Vd. II, nota 11.

5 Virgilio, Eneida, I, 87 sqq.

uirum: genitivo do plural (= uirôrum) de uir, uiri: vd. p. 46.

caelumque diemque 'o firmamento e a luz'.

8 No texto de Virgílio lê-se Teucrōrum 'dos Troianos': a substituição deste vocábulo por nostris (nostris ex oculis 'dos nossos olhos; aos nossos olhos'), além de não afectar a métrica do verso, foi exigida, como é evidente, pelo contexto.

9 intonāre 'ribombar; trovejar'; poli 'os polos; os céus'.

10 crebris... aether 'o ar refulge com a frequência dos raios'.

11 praesentem... mortem 'a morte iminente; a iminência da morte'.

12 uentōrtım ui stridēns 'rugindo com a força dos ventos'.

13 uēlum aduersa ferit 'dá na vela pela frente'.

14 Subentenda-se nauis: '[o barco] oferece o flanco às ondas'.

15 cumŭló... mōns 'um monte escarpado com a enorme massa de água'.

16 uentō concēdère 'entregar-se ao vento'.

17 Acusativo de duração: vd. NUMERAIS, p. 280 sqq.

18 Ablativo do tempo em que.

19 Presente histórico.

20 ềminēns, entis 'alto'; silvestris, $e$ 'arborizado'.

21 quam fluctus... circuinsonäbat 'ao redor da qual ressoava uma rebentação moderada'.

22 residěre 'amainar'.

\section{VI. in insŭla Bacchi}

Cum gubernātor nauem in insŭlam appulisset 1 , ègressi sumus et, ut 2 a longā aerumnā, longō quidem tempŏre humi ${ }^{3}$ iacuľmus. Corporĭbus autem a labōrĭbus laxātis, surrēxĭmus atque igne silič̌bus excussō, cēnam ${ }^{4}$ dē his, quae ad manum essent, parauı̆mus. Deinde, uirřbus uictu reuocātis, dēlēğ̌mus 5 e nōbis triginta, qui 6 custōdēs nauis manērent; uiginti autem, qui mēcum interiōra petěrent 7 ad rēs insŭlae explōrandas 8 .

Prōgressi uērō per siluam passuum cirčter a mari duo milia ${ }^{9}$, adstāmus amni 10 uinō, nōn aquā fluenti. Flumen ${ }^{11}$ erat cōpiōsum et multum, ut 12 quibusdam locis etiam posset nauigāri. Cum ${ }^{13}$ 
autem mihi placēret discěre unde orirētur fluuius, aduersō itiněre iuxta prōfluentem perrēxi ${ }^{14}$. Ac fontem ${ }^{15}$ quidem illius nullum repěri, sed multas et magnas uitēs, uuārum plēnas: ad radīcem uērō uniuscuiusque ${ }^{16}$ guttātim prōfluēbat uinum liquǐdum ${ }^{17}$, unde colligēbātur amnis. Erant autem piscēs multi in eō, uinō maxĭmē 18 et colōre et gustu simîlēs. Nōs certē captōs eōrum alĭquot cum dēuorauissēmus 19, inebriāti sumus. Chrysostŏmus autem, omnium max̌mmē è̀brius ${ }^{20}$, ui summā uōcis 21 canēbat:

Vinum bonum et suāue,

fèlix uenter, quem inträbis,

fēlix ōs, quod rigābis,

fêlix lingua, quam lauābis!

Auē merum 22, quod amō,

tuā culpā ego ${ }^{23}$ canō.

Gubernātor quoque clamābat: «Cum moriar ${ }^{24}$, hoc ēlogium meō in sepulcrō inscribĭte:

Dum uixit, bibit libenter:

bibìte uōs, qui uiuitis. 25

Cum in litŏre pernoctauissēmus, mane soluǐmus 26 uentō nōn nimis uehementi atque... amphŏris 27 a summō plēnis!

1 appellère 'dirigir para': nauem in insülam appellère 'atracar à ilha'.

2 ut a longā aerumnā 'como é natural após longas provações'.

3 humi [locativo] iacēre 'jazer por terra; ficar estendido pelo chão'.

4 cènam... parauı̆mus 'preparámos de comer com os mantimentos que tínhamos à mão ou de que dispúnhamos'.

5 dēligëre 'escolher'.

6 qui [+ conjuntivo]: oração relativa final; custōdès 'como guardas; de guarda'.

7 interiôra petère 'dirigir-se para os lugares do interior ou para o interior; ir ao interior'.

8 ad rēs... explörandas 'para explorar o que havia na ilha; para explorar a ilha': vd. p. 248 sqq.

9 passuum... duo milia 'dois milhares de passos; dois mil passos (cerca de $3 \mathrm{~km}$ )': vd. p. 282 , ao fundo.

to Dativo pedido por adstāre 'deter-se junto a'; amni... fluenti 'um rio que corria não com água, mas com vinho; um rio não de água, mas de vinho'.

11 flumen 'rio; caudal (de um rio)' : flumen cōpiōsum et multum 'caudal abundante e intenso'.

$12 u t$ [+ conjuntivo] 'a tal ponto que': oração consecutiva.

13 Cum... discère 'como eu tivesse decidido investigar': placēre [+dat.] 'decidir'. 
14 aduersō itinère iuxta prōfluentem pergĕre 'prosseguir a marcha para montante, ao longo da corrente'.

15 föns 'fonte; nascente'.

16 uniuscuiusque [unius + cuius + que] 'de cada uma [delas]'.

17 uinum liquidum 'vinho transparente'.

18 maximē 'principalmente; sobretudo'.

19 Nós... dēuorauissēmus: traduza pela seguinte ordem: curn nōs dēuorauissēmus aliquot eōrum captōs (= aliquot piscēs quōs cēperāmus).

20 maximēe èbrius 'muito embriagado ou o mais embriagado' (omnium 'de todos': vd. p. 228). Os adjectivos em -eus, -ius e -uus fazem o comparativo de superioridade com magis e o superlativo com maximmē antepostos ao positivo: p. ex., magis idōneus, maximēe idōneus.

21 ui summa uōcis 'com toda a força da voz; a plenos pulmões'.

22 merum [subent. uinum] 'vinho puro (= sem mistura de água)'.

23 ego 'é que eu'.

24 cum moriar (fut. imperfeito de moriri: verbo depoente) 'quando eu morrer'.

25 Em tradução um tanto livre:

Enquanto viveu, que bem lhe bebeu;

bebei vós também, que a morte ai vem.

26 Vd. II, nota 14.

27 amphöris a summō plēnis 'com as ânforas (= as vasilhas) cheiinhas até aos bordos'.

\section{Nauis uolans 1}

Circa meridiem, cum iam longē aberāmus 2 ab insŭlā, subǐtō saeuissĭma turbō ingruit et acatium ${ }^{3}$ uertiǧne circumactum ${ }^{4}$ in altum sustǔlit 5 . Nam uentus in uēla irruēns supra 6 in aěre suspensum ferēbat.

Septem diēs et noctēs totǐdem 7 per aěra uecti, octāuō terram quamdam cōnspicĭmus in aěre, casei maxĭmi instar ${ }^{8}$, splendĭdam et multā luce illustrātam. Dēlāti 9 ad illam et appulsi 10 ē naue ègressi sumus, explōratāque regiōne 11 habitāri eam colique 12 inuēnǐmus. Atque interdiu 13 quidem nihil inde 14 uidēbāmus: superueniente 15 uērō nocte aliae terrae, multae ac globōsae, in cōnspectum 16 nōbis ueniēbant: alia autem quaedam terra infra nōs et urbēs et flumǐna habēbat, et maria et siluas et montēs. Nescientēs sanē 17 , ubi essēmus, coniēč̆mus 18 autem nostram esse tellūrem quam infra nōs conspiciēbāmus.

1 uolans, antis "que voa; voador'.

2 Vd. p. 149.

3 Vd. II, nota 1 . 
4 circumactum 'a rodopiar'.

5 in altum tollère 'erguer até às alturas'.

6 supra 'para cima'.

7 totǐdem 'outras tantas'.

8 instar [+ genit.] 'semelhante a; parecido com; como'.

9 dēlātus, a, um: particípio passado de dêferre 'levar (de um lugar mais elevado para outro mais baixo)': vd. p. 264 sqq.

10 appulsus, a, um: particípio passado de appellère 'abordar': appulsi 'tendo nós atracado; depois de atracarmos'.

11 explōrataque regiōne 'e uma vez exploradas as redondezas'.

12 colique = et coli (infinit. pres. passivo de colère 'cultivar').

13 interdiu 'durante o dia; de dia'.

14 inde 'de lá; desse lugar'.

15 superueniente... nocte 'com a chegada inesperada da noite'.

16 in cónspectum alicui uenire 'tornar-se ou ser visível a alguém'.

17 nescientēs sanē 'sem sabermos ao certo'.

18 conicère 'calcular; concluir; presumir'.

\section{Viri uulturỉbus uehentēs I}

Cum uērō nōbis placuisset discěre ${ }^{2}$ ubi essēmus nauem firmauřmus ac dēlēctis nonnullis sociis, qui ${ }^{3}$ custōdēs manērent, prōgredîmur incerti ${ }^{4}$ quam in partem intenderēmus. Nōndum autem multum prōgressi erāmus, cum comprehensi sumus 5 a uiris multis uulturǐbus magnis uehentǐbus - nam iis auǐbus utēbantur 6 uelut equis. His iğtur uiris iniunctum est 7 , ut 8 circumuolantēs terram, si quis peregrīnus inueniātur, dēdūcant ad rēgem. Ităque nōs quoque comprehensōs ad eum dēdūcunt. Vbi primum ${ }^{9}$ rēx nōs conspexit, coniectūrā ex habǐtu ductā 10, «Terricǒlae ergō», inquit, «uōs estis, hospǐtēs ${ }^{11}$ ?» Fatentǐbus nōbis 12, "Quomŏdo iğtur», inquit, «huc uēnistis 13 tantō superātō aěre 14 ?» Et nōs illi ēnarrāuŭmus 15 aerumnas omnēs nostras.

1 uehēns, entis [+ ablat.] 'que é transportado (em ou por)': uiri uulturǐbus uehentēs 'homens montados em abutres'.

2 Vd. VI, nota 13.

3 Vd. VI, nota 6.

4 incerti 'sem sabermos bem'.

5 comprehendère 'agarrar; prender'.

6 uti (verbo depoente) + ablat. (iis auibus) 'servir-se de; utilizar'.

7 iniungère [+ dat.] 'impor; encarregar; dar uma função': his uiris iniunctum est 'foi imposta a estes homens a função; estes homens tinham sido encarregados'.

$8 u t \ldots$ ad rēgem 'de voar em redor daquela terra e de levar à presença do rei todo e qualquer estranho que encontrassem'. Si quis = si aliquis 'se alguém; se 
algum; todo aquele que'. Note que, depois de $s i, n i s i, n u m, n \vec{e}$; os pronomes ou advérbios começados por ali- perdem este elemento. Assim, por exemplo, si quis uir (= si aliquis uir) 'se algum homem; todo o homem que'; nisi quis 'a não ser que alguém', nē quis 'para que ninguém'; si quandö (= si aliquandō) 'se alguma vez'.

9 ubi primum 'logo que; assim que; apenas; mal'.

10 coniectūra ex hab̆̌tu ducta 'tirada a conclusão a partir do nosso vestuário; a avaliar pela nossa aparência'.

11 hospes, ittis 'hóspede; hospedeiro; estrangeiro'.

12 fatentǐbus nōbis 'admitindo nós que sim; perante a nossa afirmativa'.

13 huc uenistis 'vocês vieram (= vós viestes) aqui parar'.

14 tantō superātō aère 'com todo esse espaço para percorrer'.

15 ēnarrāre 'contar pormenorizadamente; contar tintim por tintim'.

\section{Lunatĩcus, Selēnitārum rēx}

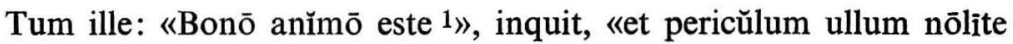
suspicāri 2 : nam ego humānus quoque sum, Lunatǐcus nōmĭne.» Deinde suas ${ }^{3}$ nōbis rēs ēnarrat, ut ${ }^{4}$ ipse dē nostrā terrā inter ipsum somnum ${ }^{5}$ sursum 6 quondam abreptus esset, et illuc dēlātus 7 regiōni imperitāret. Esse autem terram illam dicēbat Lunam. «Si uērō», inquit, «apud mē manēbĭtis, beātam uitam dēgētis. ${ }^{8}$ " Deinde nōbis maria montēsque pollič̆tus est ${ }^{9}$, ut 10 in Lunā manērēmus; at ego nullō modo ${ }^{11}$ persuadēri passus sum, et ab eō petiui 12 ut in mare dēmitterēmur ${ }^{13}$. Cum uērō uidēret mē nōlle apud sē manēre, post 14 septem diērum epŭlas nōs dēmittit.

1 bonō anĭmō esse 'estar descansado; não ter receio'.

2 A proibição ou a ordem negativa pode ser expressa pelo imperativo de nōlle (vd. p. 273) seguido de infinito: nōlite suspicāri 'não suspeitem; não receiem'.

3 suas rēs 'a sua história'; ēnarräre: vd. VIII, nota 15.

4 ut [+ conjuntivo]: oração explicativa; ut ipse abreptus esset 'como ele mesmo fora raptado'.

5 inter ipsum somnum 'enquanto dormia'.

6 sursum: traduza por: 'e levado lá para cima'.

7 illuc délātus 'uma vez lá chegado'.

8 uitam dēgère 'passar a vida; levar uma vida'.

9 Vd. p. 172, III, linhas 5-6 e vocABULÁrio respectivo (pollicēri).

10 ut [+ conjuntivo]: oração final.

11 nullō modo persuadèri passus sum 'não me deixei de modo algum convencer; eu é que não fui na cantiga'.

$12 a b$ alíquō petère ut $[+$ conjuntivo] 'pedir a alguém que'. 
13 dēmittère 'deixar cair do alto; fazer descer': ut dēmitterèmur 'que fôssemos mandados de volta; que nos deixasse voltar'.

14 post septem diērum epŭlas 'após um banquete de (= que durou) sete dias'.

\section{Dē specŭlō mirabili}

Dum in Lunā commorātus sum, multa uidi miracŭla ${ }^{1}$, è quibus unum hìc 2 referendum est. Erat enim in rēgia specŭlum maximum puteō $^{3}$ nōn adeō profundō imposǐtum. Si quis 4 iğ̌tur in puteum dēscendēbat, quae 5 in terrā nostrā dicēbantur omnia audiēbat: si uērō in specŭlum inspiciēbat, urbēs omnēs ac gentēs ${ }^{6}$ nōn minus uidēbat, quam si adstāret singŭlis ?. Tum familiārēs ego quoque uidi uniuersamque Lusitaniam ${ }^{8}$ : utrum 9 uērō illi mē quoque uiděrint necne, nōn habeō certum dicěre 10 . Vidi etiam in specǔlō Lusitānōs 11 cum Germanǐcis follem 12 pede acrǐter pulsantēs et - incrēdibřle uisu 13 - Fortūnā fauente 14 uicit sodalĭtas 15 nostra.

Haec erat Selēnitis 16 teleuisiō 17 !

1 miracŭlum, $i$ 'maravilha'.

2 hic 'aqui': não confundir com hĭc 'este'.

3 puteō nōn adeō profundō 'na boca de um poço não muito profundo': expressão em dativo, dependente de impōněre 'colocar sobre'.

4 Vd. VIII, nota 8.

5 quae tem por antecedente omnia (posposto): traduza pela seguinte ordem: audiēbat omnia quae...

6 gentēs 'povos'; nōn minus uidēbat quam si 'via precisamente como se'.

7 singŭlis [referido a urbēs e gentēs] 'em cada um deles': o dativo é pedido pelo verbo adstāre 'estar em; encontrar-se em'.

8 universa Lusitania 'Portugal todo inteiro'.

9 utrum... necne: vd. p. 227 sqq.

10 nōn habeō certum dicère 'não posso afirmá-lo com segurança'.

11 Lusitānōs cum Germanīcis 'os Portugueses com (= contra) os Alemães; entre Portugal e a Alemanha'.

12 follis, is 'fole; bola de couro': follem pede pulsāre 'impelir a bola com o pé; jogar futebol'; uidi Lusitānōs cum Germanicis follem pede acrǐter pulsantēs 'assisti a uma renhida partida de futebol entre Portugal e a Alemanha'.

13 incrēdibĭle uisu 'Oh, incrível espectáculo!': vd. p. 247.

14 Fortūnä fauente 'com a sorte a nosso favor'.

15 sodalitas, ätis 'confraria; grupo de pessoas pertencentes à mesma corporação; equipa'.

16 Selēnitis 'para os Selenitas; dos Selenitas'.

17 teleuisiō, ōnis 'televisão': trata-se - desnecessário seria dizê-lo — de um neologismo, desconhecido dos antigos Romanos!... 


\section{In terram redítu's 1}

Tum iğtur salutātō rēge et relíquis Selēnitis, conscēnsā naue 2 ad terram soluĭmus ${ }^{3}$. Dedit mihi dōna multa Lunatǐcus rēx et misit nōbiscum custōdēs mille uulturǐbus uehentēs ${ }^{4}$, qui 5 ad quingenta stadia 6 nōs dēducěrent.

Inter per aĕra nauigandum 7 multas alias terras, splendĩdas et globōsas, praeteruecti sumus et tertiō diē Oceănum satis iam clarē uidēbāmus: terra uērō nusquam, praeter eas quae in aĕre pendēbant. Quartō diē circa meridiem, mollĭter flante uentō ${ }^{8}$, in mare 9 dēposĭti sumus: serēnĭtas enim forte erat, et tranquillum mare. Tum ancŏrā iactā 10 - nam ibi mare nōn erat altum - in aquam nōs abicientēs 11 circa nauem natabāmus.

1 reditus, us 'regresso'.

2 nauem conscendĕre 'embarcar'.

3 Vd. II, nota 14.

+ Vd. VIII, nota 1.

$5 q u i[+$ conjuntivo]: oração relativa final.

6 ad quingenta stadia 'até à distância de quinhentos estádios' (aproximadamente $90 \mathrm{~km}$ : o estádio equivalia a cerca de $180 \mathrm{~m}$ ).

7 inter per aĕra nauigandum 'enquanto navegámos pelos ares fora': vd. p. 236.

8 mollitter flante uentō 'com o vento a soprar brandamente'.

9 in mare 'para o mar; no mar': com verbos que implicam uma ideia de movimento emprega-se o lugar para onde. Assim, por exemplo, intrō in atrium 'eu entro no átrio'.

10 ancŏram iacëre 'lançar a âncora; lançar ferro'.

11 in aquam sē abicère 'lançar-se à água; saltar para a água'.

\section{Cētum ${ }^{1}$ immānem adspičrmus}

Vidētur ${ }^{2}$ uērō malōrum ${ }^{3}$ saepe maiōrum initium esse mutatiō in melius. Etĕnim nōs sōlōs diēs duōs in serēnō mari cum nauigauissēmus, illucēscente tertiō ad ${ }^{4}$ orientem sōlem subǐtō uidēmus cētum maxĭmum, mille et quingentōrum stadiōrum magnitudǐne 5 : contra nōs autem ueniēbat hians 6 et longē 7 ante sē mare perturbans, spumā 8 undĭque alluente, dentēs exsěrēns ${ }^{9}$, palōrum instar ${ }^{10}$, omnēs acūtōs et ebŏris 11 in modum candǐdōs. Nōs igitur perterrìti ac crēdentēs nōs moritūrōs esse 12 ultǐmum ${ }^{13}$ allocūti sumus et complexi 14 nōs inuǐcem exspectabāmus. 
1 cètus, $i$ 'monstro marinho; baleia'.

2 uidère 'ver; na pass. parecer'.

3 malōrum... in melius: traduza pela ordem seguinte: mutatio in melius esse saepe initium malōrum maiōrum '[Mas parece que] a mudança para melhor é muitas vezes prenúncio de males maiores'.

4 ad orientem sōlem 'lá para as bandas do oriente; a leste'.

5 magnitūdō, inis 'grandeza; tamanho; comprimento'; mille et quingenta stadia 'mil e quinhentos estádios' (aproximadamente $270 \mathrm{~km}$ ): vd. XI, nota 6 .

6 hians, antis 'de goela escancarada'.

7 longē ante sē 'a uma grande distância à sua frente'.

8 spuma undique alluente 'toda banhada de espuma'.

9 exserère 'mostrar; arreganhar'.

10 Vd. VII, nota 8 ; palus, $i$ 'poste; estaca'.

11 ebŏris in modum candìdōs 'brancos como o marfim; de uma alvura de marfim'; ebur, ŏris 'marfim'.

12 Vd. pp. 234-235 e 239 sqq.: traduza por 'que iamos morrer'.

13 ultimum allocūti sumus 'falámos [uns para os outros] pela última vez; dissemos [uns aos outros] o último adeus'.

14 complecti [verbo depoente] sē inuĭcem 'abraçarem-se uns aos outros'.

\section{Cētus uirōs ipsā cum naue haurit}

At cētus iam aděrat 1 et resorbēns ${ }^{2}$ nōs ipsā cum naue hausit. Neque 3 tamen dentǐbus nōs statim comminuit, sed per interstitia eōrum nauis in interiōra illapsa est 4 .

Cum uērō intus iam essēmus, primō tenĕbrae erant, neque uidēbāmus quidquam ${ }^{5}$. Postea illō 6 hiante, uidēmus magnum specum ${ }^{7}$, et latum undĭque et altum, satis capācem ${ }^{8}$, ut deciēs 9 mille homǐnum in eō urbs habitarētur. Prōiecti passim 10 et piscēs minōrēs et animalia multa alia concīsa 11 et nauium uēla atque ancŏrae et hominnum ossa 12 et sarcǐnae. In mediō et insŭla et collēs erant, ut 13 mihi uidēbātur, dē limō 14 quem gluttiēbat cōnsidentēs. Igĭtur silua in illis 15 et omnigěnae arbǒrēs ēnātae erant 16 , et olěra multa germinauĕrant. Amb̆̌tus 17 terrae illīus stadia ducenta quadraginta 18 erat. Vidēbāmus etiam auēs marīnas, gauias 19 quidem et alcyŏnēs, quae pullōs 20 in arborǐbus ēducēbant.

1 adesse 'estar presente; estar perto': vd. p. 149.

2 resorbēns... hausit 'sorvendo... engoliu'.

3 neque tamen... statim comminuit, sed... 'contudo, sem ter tempo sequer de nos despedaçar com os dentes, foi... que...'.

4 illābi (verbo depoente) 'cair; deslizar'. 
5 quisquam, quaequam, quidquam ou quodquam 'algum; alguém; alguma coisa': nōn uidēre quidquam 'não ver mesmo nada; não ver um palmo à frente do nariz'.

6 illo $[=$ cētō $]$ hiante 'quando ela escancarou a boca'.

7 specus, us 'caverna; cavidade'.

8 satis capācem 'com capacidade bastante'.

9 deciēs (ou deciēns) 'dez vezes': deciēs mille hominum urbs 'uma cidade de dez mil habitantes'.

10 pröiecti passim 'espalhados por toda a parte'.

11 concisus, a, um 'feitos aos pedaços; aos pedaços'.

12 hominum ossa 'ossadas humanas': vd. p. 84.

13 ut mihi uidēbātur 'segundo me parecia; ao que me parecia'.

14 de limō... cōnsidentēs 'formadas a partir do lodo ou com o lodo'.

15 in illis 'nelas', isto é, nas colinas.

16 ènātae erant 'tinham-se desenvolvido', tem por sujeito silua e omnigènae arbörēs. Contudo, poderá traduzir toda a expressão por 'tinha-se desenvolvido nessas colinas uma floresta de árvores de toda a espécie'.

17 ambitus, us 'perímetro'.

18 Isto é, superior a $43 \mathrm{~km}$ : vd. XI, nota 6 .

19 gauia, ae 'gaivota'; alcyōn, ŏnis 'alcião ou alcíone (ave marinha)'.

20 pullós éducère 'criar os passarinhos; fazer ninho'.

\section{Intus in ${ }^{1}$ cêttõ}

Cernentēs 2 rēs esse dēsperātas, tunc quidem igitur abundē plōrauǐmus. Deinde uērō sociōs excitāui ${ }^{3}$ ut potui ac naue firmāta cēnam parāuľmus. Postridiē cum surrexissēmus, quotiēns hiābat cētus, uidēbāmus alias 4 quidem terram, alias montēs, alias caelum sōlum ${ }^{5}$, saepe etiam insŭlas, sēnsimusque ${ }^{6}$ adeō illum celerĭter natāre in 7 omnēs maris partēs. Cum 8 iam huius commoratiōnis consuetudinnem quamdam contraxissēmus, assumptis septem sociis prospecturus 9 omnia, in siluam ingressus sum. Quinque 10 nōndum intěgra stadia prōgressus, sepulcra multa inuēni atque in proxĭmō 11 fontem aquae pellucĭdae. Ad haec 12 canis latrātum 13 audiuı̆mus et fumus apparuit ē longinquō ${ }^{14}$ : unde 15 terram illam habitāri etiam 16 conicěre potuĭmus.

1 intus in [+ ablat.] 'no interior de'.

cernentēs 'ao vermos que'; traduza o plural rēs por 'situação'.

3 excitäre 'animar'; ut potui 'conforme pude'.

4 alias... alias... alias 'ora... ora... ora'.

5 solum 'só; apenas'.

6 sēnsimusque adeō 'e deste modo nos demos conta de que'. 
7 in omnès maris partēs 'para todas as partes do mar; por esses mares fora'.

8 Cum... contraxissēmus 'já um tanto habituados a esta espécie de residência'.

9 Particípio futuro empregado com valor final: 'a fim de observar'.

10 quinque integra stadia 'cinco estádios completos': '[ainda não tinha avançado] um quilómetro'; vd. XI, nota 6.

11 in proximō 'nas proximidades'.

12 ad haec 'além disto (ou disso)'.

13 canis latrātus (us) 'o ladrar de um cão; um cão a ladrar'.

$14 \bar{e}$ longinquō 'à distância; ao longe'.

15 unde... conicère potuimus 'por aqui pudemos nós concluir que'.

16 etiam 'até'.

\section{Faustus occursus 1}

Diligenter iğ̌tur per siluam prōgressi, seniōri 2 cuidam et iuuĕni adstitĭmus studiōsē exercentǐbus ${ }^{3}$ hortum olitōrium ac dē fonte aquam in eum dēriuantǐbus. Delectāti simul et terrǐti constiťmus: et illi 4 quoque eādem quā nōs ratiōne, ut fač̌le est ad existimandum, affecti, uōce interclūsā stabant. Post moram alĭquam senex: "Qui uōs estis», inquit, «hosp̌̌tēs? Vtrum 5 marīni quidam daemŏnēs an homìnēs infēlīcēs, nōbis simǔlēs? Etĕnim nōs quoque, homǐnēs 6 nati et in terrā nutrìti 7 , marini iam facti sumus et cum belluā hāc, quae nōs contǐnet, natāmus, nec ${ }^{8}$ accurātēe, quid dē nōbis fiat, scientēs: mortuōs 9 enim nōs esse coniciēbāmus, uiuĕre tamen crēdǐmus.» Ad haec 10 ego: «Et nōs sanē», inquam, «homǐnēs 11 noui aduěnae sumus, pater ${ }^{12}$, ipsā cum naue nudiustertius 13 hausti. Sed ēnārra tuam nōbis fortūnam, qui sis et quā 14 ratiōne huc intrauĕris.»

1 occursus, us 'acção de ir ao encontro; encontro'.

2 seniōri cuidam et iuuěni 'um ancião e um jovem': vd. VI, nota 10.

3 exercentǐbus... deriuant ǐbus 'a cultivar... a encaminhar': dativos a concordar com seniōri e iuuěni.

4 illi... affecti 'eles, perturbados também pelos mesmos motivos que nós'; ut facìle ad existimandum 'como é fácil de calcular': vd. p. 236.

5 utrum... an: vd. p. 72.

6 hominès nati 'humanos de nascença'.

7 nutriti 'criados'.

8 nec accurātē... scientēs 'sem sabermos ao certo o que nos espera'.

9 mortuōs enim... crēdìmus 'julgávamos ter morrido, mas cremos que estamos vivos'.

10 ad haec 'em resposta'.

11 hominēs noui aduěnae 'seres humanos recém-chegados'. 
12 O substantivo pater é aqui usado como fórmula de respeito para co $\mathrm{m}$ uma pessoa idosa: poderá, por isso, ser traduzido por 'tiozinho' (cf. fr. père).

13 nudiustertius 'é hoje o terceiro dia; há dois dias': note que os Romanos contavam o dia de que que se partia até ao dia em que se chegava. Assim, por exemplo, tertiō diē 'no terceiro dia; dois dias depois'.

14 qua ratiōne 'por que mótivo'.

\section{Senex nōs domum ${ }^{1}$ dēdūcit}

Ille uērō negāuit $2 \operatorname{se}^{3}$ prius uel dictūrum nōbis uel a nōbis quidquam quaesitūrum, quam hospitāli ${ }^{4}$ nōs munĕre impertiisset: assumptōsque 5 nōs domum dēduxit, quam ${ }^{6}$ sibi fēcěrat. Hīc ${ }^{7}$, cum apposuisset 8 nōbis olĕra et arboreōs fructus et piscēs, uinumque etiam ministrauisset ${ }^{9}$, satiātōs 10 interrogāuit quid nōbis accidisset. Atque ego ōrdǐne 11 ēnarrāui omnia, Olisipōne discessum 12 et tempestātem 13 et quae Bacchi in insǔlā contigěrant 14 et nauigatiōnem per aěra 15 et quae in Lunā uiderāmus 16 , imprìmis 17 puteum mirabǐlem ${ }^{18}$, et relĭqua ad dēscēnsum usque in cêtum 19.

1 Note o lugar para onde sem preposição.

2 negāuit 'recusou-se': vd. p. 212 sqq.

3 sē... quam: traduza-se pela seguinte ordem: sē uel dictūrum [esse] nōbis uel a nōbis quaesitūrum [esse] quidquam, prius quam ... O verbo quaerère 'perguntar' constrói-se com ablativo, regido de $a(a b), \bar{e}(e x)$ ou dē, da pessoa a quem se pergunta, e acusativo da coisa perguntada (quidquam 'o que quer que fosse').

4 hospitāli impertîre munère 'repartir os dons da hospitalidade'; nōs poderá ser traduzido por 'connosco'.

5 assumptōsque nōs: traduza por 'tendo-nos tomado consigo'.

6 quam sibi féceerat 'que ele fizera para si; que ele mesmo havia construído'.

7 hic [advérbio: não confundir com hic 'este'] 'aqui; então'.

8 appōnère 'pôr na mesa; servir (de comer)'.

9 uinum ministrāre 'dar vinho a beber'.

10 satiātōs 'uma vez saciados; já refeitos': o acusativo é pedido pelo verbo interrogāre. Este verbo constrói-se com duplo acusativo (acusativo de pessoa e acusativo de coisa). Contudo, o acusativo de coisa pode ser substituído, como aqui, por uma oração completiva (interrogativa indirecta).

11 ordine 'por ordem'.

12 Vd. capp. II-III.

13 Vd. cap. V.

14 Vd. cap. VI; quae 'aquelas coisas que; aquilo que', plural neutro.

15 Vd. cap. VII.

16 Vd. capp. VIII-IX; quae, vd. supra, nota 14. 
17 imprimis 'em particular'.

18 Vd. cap. X.

19 Vd. capp. XI-XIV; reliqua 'os restantes acontecimentos; tudo o mais', plural neutro.

\section{Senex nōbis suas ēnarrat rēs 1}

Ille uērō supra modum admirātus 2 uicissim ipse suas ēnarrāuit rēs, sic exōrsus ${ }^{3}$ : «Geněre ${ }^{4}$, amīci, sum quoque Lusitānus. Mercatūrae causā e e patriā nostrā ègressus cum hōc filiō et aliis multis sociis, in Italiam nauigāui, oněra 5 uaria magnā naue uehēns, quam 6 in ōre cēti solūtam forte uidistis. Atque ad Columnas Hercǔlis 7 usque fēlicĭter nauigauĭmus. Inde uērō ualidisš̌mō uentō abrepti, in altum dēelāti sumus. Hìc ${ }^{8}$ incidentēs in hunc cētum et uiri cum naue gluttìti, duōs 9 nōs, mortuis relĭquis, sōli seruāti sumus. Sepultis uērō sociis, hanc uitam uiul̆mus, olěra in hortō colentēs, in relĭquō cibō piscǐbus utentēs 10 et arbŏrum fructǐbus. Silua autem, ut uidētis, prōlixa, uitēs etiam habet multas, dē quibus uinum fit suauissimum. Et fontem 11 forte uidistis pulcherrimae aquae et frigidissimmae. Auēs aucupiō 12 capĭmus inuolantēs ${ }^{13}$, et piscēs piscāmur. Ac lacus quoque nōn longē est salsus ${ }^{14}$, piscēs alēns 15 omnigěnōs, in quō natāmus etiam, et in paruā scaphā nauigāmus, quam 16 egŏmet 17 fabricātus sum.

Anni 18 nōbis 19 prōcessērunt, ex quō hausti sumus, septem hi et uiginti.»

1 suas... rēs 'a sua história'.

2 admirātus supra modum 'cheio de admiração'.

3 sic exōrsus 'tendo assim começado'.

4 genère 'de raça': genère Lusitānum esse 'ser de nacionalidade portuguesa; ser português'.

5 onèra uaria uehère 'transportar diversas mercadorias'.

6 quam: tem por antecedente naue; quam... solütam forte uidistis 'que talvez tenham visto destroçado': vd. cap. XIII.

7 Columnae Hercŭlis 'as Colunas de Hércules; estreito de Gibraltar'.

8 hic: vd. cap. XVI, nota 7.

9 duōs nōs... sōli 'só nós dois'.

10 in reliquō cibō... utentēs 'quanto ao resto, servimo-nos como alimento; além disso alimentamo-nos': o verbo depoente uti 'servir-se de; usar' constrói-se com ablativo (cibō, piscǐbus e fructǐbus).

11 et fontem 'e quanto à fonte... ela é'; pulcherrĭmae aquae et frigidissimae: genitivo de matéria.

12 aucupiō capère 'caçar (aves)'. 
13 inuolantēs 'que entram [na baleia] a voar'.

14 salsus, a, um 'salgado; de água salgada'.

15 alēns, entis 'que alimenta; que cria': poderá ser traduzido este particípio presente apenas pela preposição 'com'.

16 quam tem por antecedente scapha 'canoa'.

17 Note o reforço do pronome pessoal com a partícula -met: egŏmet 'eu próprio'.

18 anni... septem hi et uiginti 'estes vinte e sete anos: já vinte e sete anos'.

19 nöbis: dativo de interesse que poderá ser omitido na tradução.

\section{XVIII. $\overline{\mathbf{E}}$ cētō ēuasiō}

Cum nōn ferrem ${ }^{1}$ talem in cētō uitam, exeundi ${ }^{2}$ alĭquam ratiōnem ${ }^{3}$ machinābar. Ac primō quidem placuit ${ }^{4}$ nōbis dextrō ${ }^{5}$ pariēte perfossō aufugěre. Cum ${ }^{6}$ uērō ad quinque stadia progressi intus in cēti carne nihil efficerēmus, hōc cōnsiliō abiectō 7 , incenděre siluam statuĭmus: ita quippe belluam moritūram esse ${ }^{8}$; quō factō 9 fač̣lis nōbis futūrus erat exĭtus. A caudā 10 iğ̌tur initiō factō eam incendĭmus: ac septem diēs totidemque noctēs cētus nōn sensit ardōrem; octāuō autem nōnōque aegrotāre 11 eum intellexĭmus: hiābat enim tardius 12 et, si hiāret, statim ōs claudēbat. Decĭmō undecimōque iam moribundus erat, atque male olēbat. Duodecĭmō animaduertĭmus ${ }^{13}$, nisi quis 14 illō 15 hiante suffulcīret maxillares, quōmìnus 16 claudĕre illōs posset, pericŭlum 17 esse nē clausi in cadauěre unā 18 perirēmus. Itaque ōre illius magnis trabĭbus discuneātō, 19 nauem parauǐmus, et aquā quam ${ }^{20}$ plurǐmā impoš̌tā, et necessariis relǐquis 21 . Proxīmā luce 22 cētus quidem iam erat mortuus. Nōs uērō extractam nauem et per dentium interstitia traductam placĭdēe 23 in mare dēmisĭmus.

1 ferre 'suportar': vd. p. 264 sqq.

2 exeundi: vd. p. 236 e conjugação de ire, pp. 268-270.

3 ratiō, ōnis 'meio; processo'.

4 placuit nōbis: vd. VI, nota 13.

5 dextrō... aufugère 'escavar o flanco direito [da baleia] e pôr-nos a salvo [pela abertura]'.

6 cum nihil efficerēmus "como nada conseguíssemos; como [, depois de termos aberto uns novecentos metros de galeria,] não chegássemos a resultado nenhum'.

7 cōnsilium abicère 'pôr de parte um projecto'.

8 belluam moritūram esse 'o monstro morreria': oração infinitiva dependente de statuimus (vd. pp. 234-235, 212 sqq. e 260-261).

9 quō factōo 'e sendo assim'. 
10 a cauda... initiō factó 'tendo começado pela cauda'.

11 aegrotāre 'estar doente; não estar bem (de saúde)'.

12 tardius 'com mais lentidão': vd. p. 232.

13 animaduertère 'chegar à conclusão'.

14 nisi quis 'se alguém não': vd. VIII, nota 8.

15 illo hiante 'quando ela abrisse a boca'.

16 quominus 'a fim de que não; para impedir que; para obstar a que'.

17 pericŭlum esse 'corríamos o risco de'.

18 unā 'juntamente com ela'.

19 discuneãtus, a, um 'aberto (como se fosse) com uma cunha; escorado; especado'.

20 quam plurima 'na maior quantidade possível'.

21 necessariis reliquis (pl. neutro) 'os restantes víveres necessários'.

22 proxima luce 'no dia seguinte'.

23 placìdè dēmittère 'fazer descer suavemente; arriar suavemente'.

\section{Dē caseō in pelăgō lactis fluitante 1}

Tum tergō 2 cēti cōnscēnsō, ibĭdem commorāti triduō, quod malacia erat, quartō soluǔmus ${ }^{3}$. Trecenta fermē stadia nauigauerāmus, cum in pelăgus intrauı̆mus ${ }^{4}$, nōn aquae 5 , sed lactis. Insŭla in eō conspiciēbātur alba, plēna uitı̌bus. Erat autem haec insŭla caseus maximmus flŭtans, ut postea edendō 6 experti sumus, stadiōrum quinque et uiginti circuitu: uitēs porrō 7 uuis plēnae; uērum nōn uinum inde ${ }^{8}$, sed lac expressum bibēbāmus. Quamdiu 9 igĭtur ibi mansĭmus, cibum 10 parĭter atque obsōnia insǔla illa nōbis praebuit, pōtum ${ }^{11}$ uērō lac dē uuis.

Morāti in hāc insŭlā diēs quinque, sextō soluı̌mus 12 .

1 flǚtans, antis 'que flutua; a flutuar', flutuante'.

2 tergō cēti cōnscēnsó 'tendo subido para o dorso da baleia'.

3 Vd. II, nota 14.

4 Vd. XI, nota 9.

5 Vd. XVII, nota 11.

6 edend̄̄ 'ao comermos [dele]': vd. p. 236.

7 porrō 'demais; além disso'.

8 inde 'delas [= uvas]': uērum nōn uinum inde, sed lac expressum 'mas delas não foi vinho que esprememos [e bebemos], mas leite'.

9 quamdiu 'durante todo o tempo que'.

10 cibum parŭter atque obsōnia '[forneceu-nos] igualmente pão e conduto'.

11 pōtus, us 'bebida': pōtum uērō 'mas por bebida; e no tocante a bebida'.

12 Vd. supra, nota 3. 


\section{Dē Suberipedỉbus ${ }^{1}$}

Aurā quidem nōs quādam prōsequente ${ }^{2}$, nōn nisi lēuľbus tamen fluctǐbus motō mari ${ }^{3}$, nōn iam lacteō nauigabāmus, sed salsō mari et caeruleō. Octāuō autem diē, postquam ab caseō fluitante ancŏram soluerāmus, uidēmus homīnēs multōs per mare discurrentēs ${ }^{4}$, omni ex parte ${ }^{5}$ nōbis simı̌lēs, corporĭbus et statūrā, pedĭbus sōlum exceptis ${ }^{6}$; hōs enim habēbant ex suběre 7 , a quō nempe etiam appellabantur Suberipědēs. Mirabāmur igĭtur ualdē, cum uidērēmus illōs nōn mergi, sed èminentēs ${ }^{8}$ super fluctus ac sine metu uiam ${ }^{9}$ facientēs. Atque adeunt ad nōs etiam nōnnulli et Lusitānā linguā salūtant dicuntque in suam sē patriam Suberiam 10 contenděre. Et aliquōusque 11 iuxta currentēs nōbiscum iter faciēbant: deinde ab nostrā uiā dēflectentēs 12 abỉbant fēlīcem nōbis nauigatiōnem precāti 13 .

1 Suberīpēs, pedis 'os Pés-de-Cortiça': composto formado a partir de suber, ěris 'cortiça' + pēs, pedis 'pé'.

2 aurā... nōs quadam prōsequente 'com uma brisa de feição'.

3 nōn nisi... motō mari 'e com uma ondulação ligeiramente encrespada'.

4 discurrēns, entis 'que corre de todos os lados; a correr de todas as direcções'.

5 omni ex parte 'em todos os aspectos; em tudo'.

pedíbus sōlum exceptis 'com uma única excepção: os pés'.

7 Vd. supra, nota 1.

8 èminentēs 'que se mantinham de pé'.

9 uiam facientēs 'que caminhavam'.

10 Suberia, ae 'Subéria', nome criado a partir de suber (vd. supra, nota 1) e que significa 'terra do súber (= cortiça)'.

11 aliquōusque 'durante algum tempo'. taram-se'.

12 dēflectentēs abibant 'desviando-se afastavam-se; desviaram-se e afas-

13 precātus, a, um 'que suplicou; que desejou': nōbis precāti fêlicem nauigatiōnem 'não sem nos terem desejado uma boa viagem'.

\section{Socius quidam tristem fabŭlam narrat}

Inter aequālēs, qui mēcum nauigābant, erat Amātus 1 quidam, uir mulierōsus facileque amōre flagrans ${ }^{2}$; glōriabātur ${ }^{3}$ tamen, quaqua 4 incēdĕret, omnēs muliĕrēs sēsē sectāri. Quā dē causā amīci eum dēridēbant atque Peramatōrem ${ }^{5}$ saepe appellābant.

Illā diē 6 autem, nōbis ōtiōsis 7 , quia mare erat placĭdum, unus è sociis: «Peramātor», inquit, " nōbis narra fabŭlam amatōriam 8 , 
ut anĭmōs remittāmus ${ }^{9} . »$ Tunc omnǐbus silentǐbus 10 Amātus sic nōn inuītus 11 incēpit: "Iubētis mē, amici, fabŭlam amatōriam narrāre: audite igĭtur tristem Pyrămi Thisbēsque 12 fabŭlam. Ōlim iuuěnis quidam Babylōnius, cui nōmen erat Pyrămus, ualdē amābat pulcherrĭmam puellam, nōmine Thysbēn, et illa 13 illum contra: qui 14 est amor cultu optĭmus. Eōrum parentēs autem inimìci inuĭcem 15 nē 16 sinēbant quidem altěrum 17 altěram uidēre. Quārē Pyrămus clam forāuit commūnem 18 pariětem in gemǐnis aedı̌bus et per rimam 19 amantēs mussitābant plēna amōris uerba. Illi tandem, cum nōn amplius discidium tale ferrent 20 , cōnsilium cēpērunt 21 domō 22 aufugěre atque extra 23 murōs conuenire iuxta mōrum 24 quamdam ab ambōbus nōtam. Diē certā 25 Thysbē, ut 26 composĭtum fuĕrat, domō aufŭgit et sē confert 27 ad locum, ubi erat mōrus. Tempus erat cum iam summa pagōrum tēcta procul fumābant et umbrae grandiōrēs 28 ex altis montǐbus porrigēbantur. Lunā plēnā lucente ${ }^{29}$, puella ad mōrum peruěnit; Pyrămus autem nōndum ibi erat. Subĭtō pauĭda Thysbē uidet leaenam appropinquantem et perterrita in speluncam, quae in proxĭmō erat, perfŭgit palliŏlum dēmittēns ${ }^{30}$, quod saeua bēstia ōre sanguĭne imbūtō statim scidit. Paulō post Pyrămus aduěnit et, cum Thysbēs 31 palliŏlum scissum ac sanguine infectum 32 uidēret et leaenam procul fugientem, putāuit bēstiam Thysbēn uorauisse. Tum suspiciēns 33 in caelum, ingemiscēns ait: «ర̄ misella 34 Thysbē, indignē 35 adempta mihi, heu!, meā culpā fortūna tē ipsam 36 abstŭlit mihi. Nunc tamen acč̆pe signa amōris mei !» et gladiō dēstrictō pectus transfixit. Interea Thysbē $\bar{e}$ speluncā exit et - horribille dictu! 37 amante moriente uisō ${ }^{38}$, eōdem gladiō se interēmit ${ }^{39}$. Sanguis ē uulnerĭbus exsūlit et mōra, hōc contamināta ${ }^{40}$, ex eō tempŏre colōrem 41 duxērunt cruentum. Sic 42 sēmōtōs, dum uixěrant, amantēs iunxit mors.»

Amātus quidam 'um tal Amado; um tipo que se chamava Amado': vd. p. 107.

2 facìle amōre flagrans 'que se apaixona facilmente'.

3 glöriāri 'gabar-se'.

4 quaqua incēdèret 'para onde quer que fosse'.

5 Peramātor, ôris 'aquele que ama muito; pinga-amor; lamecha; bajoujo'.

Sobre o género de diēs, vd. p. 91.

nōbis ōtiōsis 'estando nós sem ter nada que fazer; estando nós desocupados'.

fabŭla amatōia 'uma história de amor'.

9 animum remittère 'distrair-se'; ut + conjuntivo: oração final.

10 omnibus silent ǐbus 'estando todos calados; perante o silêncio geral'.

11 nōn inuitus 'não contrariado; de bom grado'.

12 Note a declinação (com desinências gregas) de Thysbē: N. V. Thysbē, Ac. Thysbēn, G. Thysbēs, D. Thysbae, Ab. Thysbē. 
13 illa illum contra 'ela, pelo seu lado, [amava-o] a ele; ela correspondia ao seu amor; ela a ele'.

14 qui... optǐmus 'que é a melhor forma de amar'.

15 inimici inuicem 'inimigos reciprocos; inimigos uns dos outros': traduza apenas por 'inimigos; que eram inimigos'.

$16 n \bar{e} . .$. quidem 'nem sequer'.

17 altěrum altèram uidère 'ver-se um ao outro'.

18 commūnis pariēs in gemĭnis aedǐbus 'a parede comum a duas casas; a parede que separa duas casas'.

19 rima, ae 'fenda'.

20 ferre discidium 'suportar a separação'.

21 cōnsilium caperre 'tomar a decisão de; resolver'.

22 Note a ausência de preposição.

23 extra murōs conuenire 'reunir-se ou encontrar-se fora da cidade'.

24 mōrus, $i$ (feminino) 'amoreira': note, no final da história, mōrum, $i$ (neutro) 'amora (fruto)': vd. pp. 46-47, N.B.

25 diē certa 'no dia fixado': vd. supra, nota 6.

26 ut composìtum fuěrat 'conforme entre eles haviam combinado'.

27 sē conferre 'dirigir-se'.

28 grandiōrēs 'cada vez maiores; que mais e mais se alongavam'.

29 Lunā plēnā lucente 'à luz da lua-cheia'.

30 dēmittère palliŏlum 'deixar cair a mantilha'.

31 Vd. supra, nota 12.

32 sanguine infectum 'manchado de sangue'.

33 suspicère in caelum 'olhar para o céu'.

34 Diminutivo que indica ternura, carinho: traduza, apenas, por 'pobre'.

35 indignē 'indignamente; sem o merecer': indigne adempta mihi 'que foste arrebatada à minha afeição no verdor dos anos'.

36 tē ipsam: note o reforço do pronome pessoal.

37 Vd. p. 247.

38 amante moriente uisō 'ao ver o namorado já moribundo'.

39 sē interimère 'suicidar-se'.

40 hōc (sanguine) contamināta 'por ele manchadas'.

41 colōrem ducère cruentum 'tomar a cor do sangue; tingir-se de vermelho'.

42 Traduza pela seguinte ordem: Sic mors iunxit amantēs sēmótōs, dum uixěrant (“Separados em vida, a morte os dois amantes uniu”).

\section{Dē Colocynthopirātis ${ }^{1}$ et Caryonautis ${ }^{1}$}

Biduō inde tempestatǐbus iactāti ${ }^{2}$, diē tertiō in Colocynthopirātas incidĭmus. Hi sunt homĭnēs feri, dē propinquis insŭlis latrōcinia ${ }^{3}$ exercentēs contra eōs qui praeternaulggant. Nauēs habent dē colocynthĭde 4 magnas, longitudǐne cubitōrum ${ }^{5}$ sexaginta. Cum enim siccātae sunt cucurbĭtae 6 et excauātae, demptis 7 medullis, in iis naulgant, malis 8 utentēs arundineis, prō uēlō 9 autem foliis colocynthĭdis 10 . 
Hi igĭtur impětu 11 in nōs factō cucurbitārum sēminna 12 iaculantur. Cum diu aequō 13 Marte pugnauissēmus, circa meridiem uidēmus a tergō 14 Colocynthopiratārum adnauigantēs Caryonautas 15. Erant autem inimici inuǐcem 16: itaque illi, cum aduentāre hōs sentīrent, omissis 17 nōbis conuersi 18 ad ipsōs pugnauērunt 19 dē nauľbus.

1 Compostos de origem grega: Colocintopiratas (colócyntha 'abóbora' + peirátes 'pirata'); Carionautas (cáryon 'noz' + náutes 'marinheiro').

2 Vd. V, nota 1.

3 latröcinia exercēre 'exercer a pirataria; dedicar-se à pirataria'.

4 dē colocynthìde 'feitas de abóbora': colocynthis, ùdis 'aboboreira'.

5 cubitōrum sexaginta 'sessenta côvados (= aproximadamente $40 \mathrm{~m}$ ) [de comprimento]'.

6 cucurbíta, ae 'abóbora'.

7 demptis medullis 'tiradas as medulas; sem medula'.

8 malis: ablativo do plural de malus, $i$ 'mastro (de navio)', pedido por uti: vd. VIII, nota 6; malus arundineus 'mastro de cana'.

9 prō uēlō 'por vela; como vela'.

10 Vd. supra, nota 4.

11 impètum facère in aliquem 'atacar'.

12 cucurbitärum sēminna 'sementes de abóbora; pevides de abóbora': Vd. supra, nota 6 .

13 aequō Marte 'com Marte (deus da guerra) igual', isto é, 'sem vantagem para qualquer das partes em conflito’; cum + conj: oração causal.

14 a tergo 'pela retaguarda'.

15 Vd. supra, nota 1.

16 inuǐcem 'reciprocamente; mutuamente'; inimici inuǐcem 'inimigos uns dos outros': traduza simplesmente por 'inimigos'.

17 omissis nōbis 'tendo-nos largado'.

18 conuersi 'que se voltaram': traduza por 'tendo-se voltado'; ad ipsōs 'para os recém-chegados'.

19 pugnāre dē nauı̆bus 'lutar de barco a barco; travar uma batalha naval'.

\section{Dẻ latrōnibusus ${ }^{1}$ delphīnis uectis}

Nōs intěrim uềlō 2 sublātō fuğmus, pugnantēsque eōs reliquĭmus. Et uictōrēs apparēbat ${ }^{3}$ futurōs esse Caryonautas, quia plurēs ${ }^{4}$ pugnabantque dē robustiōrǐbus nauigiis. Nempe nauēs erant ipsis dē putaminǔbus ${ }^{5}$, dimidiātae nucēs 6 et excauātae: magnitūdō uniuscuiusque 7 nucis dimidiae erat in longum ${ }^{8}$ passus quinděcim 9 .

Nōndum enim sōl occiděrat, cum a dēsertā quādam insŭlā uersus nōs perrexērunt uiri circǐter uiginti, delphīnis magnis uecti 10 . Latrōnēs hi quoque erant: delphīni autem eōs tutō 11 ferēbant, exsultantēsque 12 equōrum instar ${ }^{13}$ hinniēbant. Cum uērō prope essent, iaculāti 
sunt in 14 nōs sēpias 15 siccātas et ocŭlōs cancrōrum 16 . Nōbis 17 uērō sagittas et iacŭla mittentǐbus, nōn durauērunt ${ }^{18}$, sed uulnerāti plērique eōrum ad insŭlam confugērunt.

1 latrō, ōnis 'salteador'; delphinis uecti 'montados em golfinhos': vd. VIII, n. 1.

uēlum tollère 'içar a vela'.

3 apparēere 'ser bem evidente': note a oração infinitiva seguinte.

4 plurēs '[sendo] em maior número]; [eram] em maior número [e]'.

5 putāmen, inis 'casca de noz': ipsis de putaminı̆bus '[feitas] das próprias cascas de noz'.

6 nux, nucis 'noz': omita este substantivo na tradução; dimidiātae... et excauãtae 'partidas ao meio e sem miolo'.

7 Vd. VI, nota 16: uniuscuiusque nucis dimidiae 'de cada uma dessas metades de noz'.

8 in longum 'de comprido'.

9 passus quindècim 'quinze passos; uns vinte e três metros'.

10 Vd. supra, nota 1.

11 tutō 'com toda a segurança'.

12 exsultantèsque 'e que saltavam; e a saltar'.

13 Vd. VII, nota 8.

14 in [+ acusat.] 'em direç̧ão a; contra'.

15 seepia, ae 'choco (molusco marinho)'.

16 cancer, cancri 'caranguejo'.

17 nōbis... mittentǐbus 'tendo nós ripostado com setas e dardos'.

18 durāre 'resistir (ao ataque)'.

\section{Silua max̌̆ma in mediō mari}

Nōndum quingenta stadia prōuecti erāmus, cum siluam uidīmus maxĭmam et dēnsam pinuum ${ }^{1}$ et cupressōrum. Ac nōs quidem putabāmus continentem ${ }^{2}$ eam esse: at illud pelăgus erat prōfundum, cōnsĭtum arborībus radice 3 carentǐbus: stabant arbǒrēs nihilōmīnus 4 immōtae, quasi 5 rēctae innantēs. Apprōpinquantēs igǐtur, uniuersā 6 rē cōnsiderātā, in dubiō 7 erāmus quid agendum esset 8 : neque enim nauigāri per arbŏrēs potěrat ${ }^{9}$, quae 10 dēnsae essent et cōntinuae, neque reuerti facĭle uidēbātur ${ }^{11}$. Ego uērō, cōnscēnsā 12 arbŏre maxĭmā, prōspexi quōmŏdo 13 ulteriōra sē habērent, ac uidi ad 14 stadia quinquaginta aut paulō plura esse siluam: tum mare rursus excipĕre 15 aliud. Itaque placuit 16 nauem in comas arbŏrum (dēnsae enim erant) imposĭtam traducěre, si possēmus, in mare altěrum 17. Idque 18 fēcĭmus. Reuinctam 19 enim magnō fune, arborĭbus 20 cōnscēnsis, magnō labōre eō ${ }^{21}$ pertraxĭmus, ramisque eam superimposul̆mus, ubi 22 uēlis 23 passis uelut in mari nauigauĭmus, uentō secundō 24 prōmōti. 
1 pinuum et cupressôrum: genitivos de matéria.

2 continentem eam esse 'que ela [ = floresta] era terra firme'.

3 radice carentibus 'carecidas de raiz; sem raiz'.

4 nihilōminus 'não obstante', isto é, apesar de as árvores não terem raiz.

5 quasi rēctae innantēs 'como se flutuassem de pé'. ângulos'.

6 uniuersā rē cōnsiderātā 'depois de considerarmos a situação por todos os

7 in dubiō esse 'estar na dúvida; hesitar'.

8 Subentenda-se nöbis: vd. p. 252 sqq.

9 neque potèrat 'nem era possível'.

10 quae... essent: oração relativa causal (note o conjuntivo).

11 Vd. XII, nota 2.

12 cōnscēnsā arbŏre maximāa 'tendo subido à árvore mais alta; subi à árvore mais alta $e^{\prime}$.

13 quōmödo ulteriōra sē habērent 'como é que as coisas se passavam lá mais para diante'.

14 ad [+ acusat.] 'numa extensão de; até à distância de': vd. XI, nota 6 .

15 excipère 'estender-se'.

16 Subentenda-se mihi: vd. VI, nota 13.

17 Vd. p. 67.

18 idque féč̆mus 'e foi isso o que fizemos; e assim fizemos'.

19 Subentenda-se nauem.

20 arborǐbus cōnscēnsis 'subimos às árvores'.

21 Advérbio: 'para lá'.

res) que'.

22 ubi 'onde; e foi sobre eles (= sobre os ramos; sobre a ramagem das árvo-

23 uēlis passis 'de velas pandas'.

24 Vd. II, nota 10.

\section{Dẽ pullis in mare abiectis}

Superāiā tamen 1 siluā ad aquam peruēnìmus. Subĭtō magnum inter sociōs tumultum factum est, aliōs 2 clamantēs «Eōs seruāte!», aliōs cachinnōs èdentēs ${ }^{3}$. Causa clamōris illius haec ${ }^{4}$ fuit: coquus, uir iracundus ac stomachōsus, cui nōmen erat Salsus 5 , cum pullis, quōs in naue portabāmus, cibum ${ }^{6}$ obiēcisset et illi (nauseābant fortāsse!) èsse 7 nōllent, caueam in mare abiēcit dicēns: «Quia ēsse nōlunt, bibant!» 8

Erat etiam hic coquus crassissǐmus ac paruā ${ }^{9}$ statūrā. Aliquandō Lingulāca 10 , cum eum uidēret in triclinium intrantem ad cēnam appōnendam 11: «Ēn uōbis ${ }^{12}$ », inquit, «succinctōrium ${ }^{13}$ fartissǐmum!»

1 tamen 'apesar de tudo; mesmo assim'.

2 aliōs... aliōs 'uns... outros'.

3 cachinnōs èdère (não confundir com èdère 'comer') 'soltar gargalhadas; rir às gargalhadas'. 


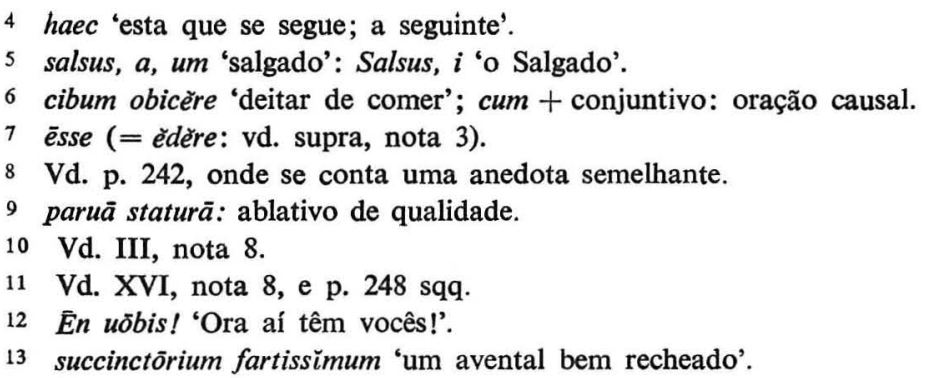

\section{Hiătus 1 in mari}

Fèlīeès autem atque hilărēs per puram pellucidamque aquam nauigaul̆mus, dōnec 2 ad hiātum constiterĭmus magnum ex aquā 3 discēdente ortum. Nauis quidem nostra, uēla ${ }^{4}$ nōbis contrahentǐbus, nōn facìle stetit ${ }^{5}$, cum ${ }^{6}$ parum abesset quin dēferrētur. Nōs uērō capitǐbus 7 porrectis dēspicientēs, prōfundum 8 uidēbāmus uel mille stadiōrum, terribřle admŏdum 9 atque incrēdibřle: stabat enim aqua uelut diuīsa. Sed circumspicientēs ad dextram uidēmus ē longinquō 10 pontem iniunctum ex aquā 11 , quae iungēbat utriusque 12 pelăgi summas ōras, et ex unō mari in altěrum transfluēbat. Huc ${ }^{13}$ igĭtur agitantēs 14 nauem rēmis 15 cursum flexĭmus, multōque labōre traiēcĭmus, quod nunquam spērauerāmus.

1 hiätus, us 'abertura; abismo'.

2 dōnec [+ conjuntivo] 'até que'.

3 ex aquā discēdēnte ortum 'formado pela bipartição das águas'.

4 uèla contrahère 'colher as velas'.

5 stāre 'deter-se': nōn facŭle stetit 'não foi fácil que ela se detivesse; dificilmente se deteve'.

6 cum... dêferrētur 'pois (= visto que) pouco faltou para [nele = abismo] se precipitar; 'tendo estado a ponto de [nele] se precipitar'.

7 capitǐbus porrectis dēspicientēs 'de pescoço esticado, olhámos lá para baixo'.

8 pröfundum uel mille stadiōrum '(que o abismo tinha) uma profundidade de uns mil estádios (= cerca de $180 \mathrm{~km}$ )’ vd. XI, nota 6 .

9 admŏdum: vd. IV, nota 5.

$10 \bar{e}$ longinquó 'a uma grande distância'.

11 pontem iniunctum ex aquā 'uma ponte [feita] de água': note que pōns, pontis é masculino.

12 utriusque pelăgi summas öras 'os bordos de um e outro mar'.

13 huc 'foi para aqui que; foi para esta ponte de água que'.

14 agitāre navem 'fazer avançar o barco'.

15 rēmis 'com os remos; a remo; a poder de ou à força de remos'. 


\section{Ad insŭlam quamdam mirabǐlem appellïmus 1}

Hinc ${ }^{2}$ excēpit nōs mare plač̌dum, cum ${ }^{3}$ uespěrā 4 iam ingruente uersus prōram uidĭmus insŭlam latam et humĭlem ${ }^{5}$, stadiis distantem ${ }^{6}$ nōn minus quingentis. Circa mediam uērō noctem iam prope erāmus et aura quaedam circa nōs spirābat admirabülis, suāuis et odōra, qualem ${ }^{7}$ dicunt spirāre ab Arabiā fēlīici ${ }^{8}$. Delectāti odōre et optǐma 9 quaeque post longōs labōrēs dum spērāmus, breuissimmō 10 iam interuallō aberāmus ab insǔlā. Surgente autem diē, et ${ }^{11}$ portus uidēmus multōs circumcirca, tutōs 12 a fluctǐbus et spatiōsōs, fluminaque pellucĭda placĭdē exeuntia 13 in mare: ad haec ${ }^{14}$ prata et siluas et canōras auēs, tum 15 in litoríbus modulantēs, tum multas 16 in ramis. Aēr porrō 17 leuis et mollĭter spirans circumfüsus 18 regiōni erat, atque aurae quaedam suāuēs lēni ${ }^{19}$ flatu siluam mōtābant. Hisce 20 omnìbus dum dēmulcēmur, appulĭmus 21 , firmatāque in portu naue, èscendǐmus hōc 22 anĭmō ut insǔlam explōrarēmus.

1 appellère ad [+ acusativo] 'aportar a'.

2 hinc 'a partir daqui', isto é, depois de transposto o abismo pela ponte de água.

3 cum [+ indicativo]: oração temporal.

4 uespèrā iam ingruente 'já ao cair da tarde'.

5 humilis, $e$ 'pouco elevado; baixo'.

6 distantem nōn minus 'a uma distância não inferior': vd. XI, nota 6.

7 qualem 'como a que'.

8 Este facto é narrado por Heródoto, III, 113. A Arábia Feliz (= Fértil) era assim designada, por oposição à Arábia Petreia e à Arábia Deserta, por ser a região mais fértil do país. Recorde-se, contudo, o que diz Camões em "Junto de um seco, fero e estéril monte", onde (v. 8) o nome «é feliz, por antífrase, infelice".

9 Traduza pela seguinte ordem: dum spērämus optǐma quaeque post longōs labōrēs 'enquanto esperamos ou esperançados em melhores dias após tão longas provações'.

10 breuissimōo interuallō abesse [ab + ablat.] 'estar a pequeníssima distância de'.

11 et portus... fluminaque 'não apenas portos... mas ainda rios'.

12 tutus a fluctǐbus 'abrigado das ondas': portus tutus a fluctǐbus 'porto de abrigo'.

13 plač̆dē exire 'correr mansamente'.

14 Vd. XIV, nota 12.

15 tum... tum 'não só... mas também'; modulāri (verbo depoente) 'soltar [os seus] trinados'.

16 multas 'estas em maior número'.

17 porro 'além disso; para mais'.

18 circumfüsus regiōni erat '[uma viração leve e branda] envolvia aquela terra'. 
19 lèni flatu 'com o seu doce bafejo'.

20 Hisce... dum dēmulcēmur 'encantados com todas estas maravilhas'.

21 Vd. supra, nota 1.

22 hōc anìmō ut [+ conjuntivo] 'com o intuito de'.

XXVIII. «Carŏle, exč̆ta ${ }^{1}$ tē è somnō!»

Prōgredientēs nōs per flōrĭdum pratum

«Exč̌ta tē ē somnō, Carŏle mi! 2» mater mea dicēbat. «Quam diu ${ }^{3}$ uērō dormiuisti!»

Tunc mē lentum in umbrā iacēre 4 intellexi, capĭte in herba requiēscente, dum mater mea folia arìda mollĭter abstergēbat 5 quae dē arborĭbus in faciem meam dēsŭper uolitauěrant. «Mater», inquam, «quam mirum somnium somniāui!»

Tum ei narrāui omnēs 6 eas rēs miras, dē quibus tu, lector $\mathrm{mi}^{7}$, modo lēgisti ${ }^{8}$. Cum finem fēcissem ${ }^{9}$, mater mē ōsculāta est et subrīdēns: «Mirum quidem somnium somniauisti. Nunc uērō domum curre 10 ad cēnam, nam sērum diei iam est». Itaque exsurrexi atque ēsuriēns 11 cito abscessi, dum mater mea sōlis occāsum contemplābat et dē omnǐbus rēbus miris 12 , quas 13 expertus eram, cōgitābat. sesta!'

1 sē excitāre ē somnō 'acordar; despertar'.

2 mi: vocativo de meus, a, meum: Carōle mi 'ó meu querido Carlos'.

3 Quam diu uẽrō dormiuisti! 'Mas que grande sonada! Mas que grande

4 Cf. I, nota 1; intellegĕre 'aperceber-se; dar-se conta'.

5 molliter abstergĕre 'limpar suavemente; retirar docemente'.

6 omnēs eas rēs miras 'todas aquelas maravilhas'.

7 lector $m i$ 'meu caro leitor': vd. supra, nota 2.

8 modo legère 'ler há pouco; acabar de ler'.

9 finem facère 'acabar': cum finem fëcissem 'como eu tivesse acabado [a minha narrativa]; acabada a narrativa; quando acabei'.

10 domum currère ad cēnam 'correr para casa, para jantar'; traduza a expressão do texto por: 'Mas agora corre para casa: são horas de jantar'.

11 èsuriēns, entis 'esfomeado; a morrer de fome'.

12 Cf. supra, nota 6.

13 quas expertus eram 'que eu tinha experimentado; por que tinha passado'. 


\section{I I P A R T E}

- Cícero: o elogio das letras e o conceito de glória.

- Breve antologia de Catulo.

— Salústio: um conceito de história.

- Horácio: três temas de cultura. 
(Página deixada propositadamente em branco) 


\section{CÍCERO (106-43 a.C.): O ELOGIO DAS LETRAS \\ E O CONCEITO DE GLÓRIA}

(Pro Archia poeta, VI-XII)

\section{O elogio das letras.}

O discurso em defesa do poeta Aulo Licínio Árquias (Pro A. Licinio Archia poeta oratio), pronunciado em 62 a.C., quando Cícero andava pelos 44 anos de idade, pertence ao número dos chamados discursos judiciários, isto é, daqueles em que o Orador debateu perante os tribunais causas de maior ou menor importância. Contudo, ele representa, entre tantas outras peças oratórias, onde o Arpinate toma posição de defensor ou acusador, um caso particularmente curioso, porquanto se não discute nele qualquer das questóes costumeiras dos tribunais romanos - assassínios, tentativas de envenenamento, concussões, usurpação de heranças, sacrilégios, depredações várias, etc. - , mas um pleito fora do vulgar e que a pessoa do réu especialmente singulariza: é a demanda de um poeta grego que se havia tornado cidadão de Roma, mas cuja cidadania alguém ${ }^{1}$ pretendeu impugnar. Demais, tratava-se de um poeta de quem Cícero recebera lições na meninice ${ }^{2}$ e a quem, em parte por esse motivo, defende não apenas com o calor e a veemência de advogado, senão também com a natural veneração de discípulo ${ }^{3}$.

Em abono da verdade, o Pro Archia não é uma obra-prima da eloquência judiciária, pois nem o seu plano tem a regularidade perfeitamente modelar de outros discursos do A. (embora apresente uma divisão análoga à das outras peças deste género), nem o contexto nos revela aquele poderoso espírito e aquela abundância dialéctica que encontramos em outras orações, nomeadamente nas Catilinárias ou na Defesa de Milão, esta muito justamente considerada uma das obras capitais da eloquência forense. $4 \mathrm{E}$, no entanto, extremamente

1 Mais propriamente um tal Grátio, personagem inteiramente obscura e, ao que parece, «testa-de-ferro» do partido pompeiano.

2 Vd. texto da p. 12.

3 Sobre os outros motivos prováveis que levaram Cícero a aceitar a defesa de Árquias, vd. C. A. Louro Fonseca, Defesa de Arquias in Cf́cero-I. Lisboa, Verbo, 1974, pp. 171-172; quanto aos aspectos jurídicos da causa, ibidem, pp. 172-174.

4 Cf. Tácito, Diálogo dos oradores, 37. 
curioso e muito sugestivo sob o aspecto histórico-literário, não somente pelas contribuições que dá para a história de certos conceitos e noções que informam a literatura latina, como ainda, e muito principalmente, por uma digressão provocada pelo louvor entusiástico do talento de Árquias. ${ }^{1}$ Trata-se do notável elogio das letras, e da cultura em geral - e, na sequência, a justificação do desejo de glória -, com que o Orador preenche a segunda e última parte do discurso (argumentum extra causam).

Pela primeira vez, um tribunal romano ouviu um louvor deste género, e pela primeira vez, também, pôde um Romano confessar, publicamente, o orgulho de ser escritor. O facto é de transcendente significado, se tivermos em conta os preconceitos que ainda dominavam a sociedade romana no séc. I a.C., e se nos lembrarmos, também, de que a cultura, humanitas (ou, como os Gregos diziam, paideia), tem um sentido supranacional (vd. cap. VI sqq.). Além disso, proclamar o valor da cultura equivalia a reconhecer a vitória espiritual do helenismo, o que, evidentemente, contrariava a por vezes cega e retrógrada grauitas romana: «É que - dirá Cícero no capítulo $\mathrm{X}$-- se alguém supõe que se colhe dos versos gregos menos fruto de glória que dos latinos, redondamente se engana: as obras gregas são lidas em quase todas as nações, ao passo que as latinas se confinam ao seu território, sem dúvida pequeno.» 2 Estas palavras, pela sua franqueza e desenvoltura, constituem, assim, uma antecipação daqueloutras com que, anos mais tarde, Horácio viria a apregoar a vitória espiritual dos Gregos sobre os seus vencedores nas armas, os Romanos:

Graecia capta ferum uictorem cepit et artes intulit agresti Latio. 3

«A Grécia [politicamente] vencida venceu [pela cultura] o seu feroz conquistador e introduziu as artes no inculto Lácio.»

1 Uma das muitas hipérboles de Cícero. Com efeito, Árquias não foi o poeta inspirado que o discípulo grato e interessado nos quer fazer crer. Ao que parece (vd. cap. VIII), Árquias pouco mais era do que um repentista, um improvisador fácil e brilhante. De resto, a sua obra perdeu-se, e dos epigramas que, na Antologia Grega, lhe são atribuídos, nenhum é da sua autoria. $\mathrm{O}$ exagero do Orador poderá explicar-se, não apenas pela veneração do discípulo, como ainda pela promessa, que Árquias lhe fizera, de escrever um poema sobre as glórias do seu consulado, promessa que, de facto, nunca chegou a cumprir (vd. cap. XI e n. 52 à tradução).

2 Cf. As Tusculanas, I, 3: Doctrina Graecia nos et omni litterarum genere superabat «Superior a nós era a Grécia na cultura e em todos os géneros literários».

3 Epistolas, II, I, 156-157. 
Logo no Exórdio ${ }^{1}$, Cícero anteçipa-se, por meio de uma hábil praemonitio, à estranheza que possa resultar de a defesa de um poeta ser feita por um orador: a verdade é que, se Árquias é poeta e Cícero orador, também este, apesar de advogado e de tribuno político, se não tem dedicado exclusivamente às lides da eloquência; também ele cultivou, algumas vezes, a poesia, quer como autor de versos latinos, quer como tradutor de poemas gregos.

Mas esta praemonitio alcança especial relevo, quando Cícero proclama com ênfase que não existem linhas divisórias entre as diversas modalidades da cultura, por isso mesmo que a todas une, no seu entender, como que uma espécie de vínculo comum e «um certo grau de parentesco». 2 Este conceito, herdado que foi de Platão, manifesta, só por si, uma largueza de pensamento notável e inteiramente nova na Roma do século I a.C. É preciso não perder de vista, repetimo-lo por outras palavras, a estreiteza intelectual do meio ambiente e, sobretudo, os particularismos nacionalistas e o espírito de rotina que ainda então dominavam a sociedade romana: tão impedida estava ela de aceitar e de se integrar numa noção ampla de cultura, que ainda pela mesma época o historiador Cornélio Nepos, ao escrever a biografia de Epaminondas, 3 naturalmente confessa ser a música uma arte para gente de baixa condição e a dança uma prática infamante... ${ }^{4}$

Mas que se entende por cultura, segundo o pensamento ciceroniano? Que significa a humanitas, de que nos fala a Defesa de Árquias, ou, por outras palavras, a doctrina ingenuarum et humanarum artium a que se refere o Do orador? 5 Precisamente a que se funda no pensamento helénico e significa o mesmo que a paideia dos Gregos, 6 porquanto abrange, como esta, três ramos principais: as letras, a música e a ginástica.

Eis aqui, afinal, segundo a lição dos Gregos, que Cícero plenamente recebe, o que constitui a cultura humana. Nestes três campos

1 I, 2.

2 I, 2.

3 Epaminondas, I, 2.

4 Que pensaria um Grego destas palavras, se na Grécia a formação dos jovens se fazia, juntamente com a prática da ginástica e o estudo das letras, pelo aprendizado da música (canto e dança)?! Vd. M. H. DA Rocha Pereira, Estudos, de História da Cultura Clássica. I. Cultura Grega. Lisboa, F. C. Gulbenkian 51980 , p. 312 sqq.

5 III, 31.

6 Cf. Aulo Gélio, Noites áticas, XIII, 17. 
principais se obtém e desenvolve a cultura do homem livre, por forma a fazer dele um ser moral e fisicamente perfeito: mens sana in corpore sano são as palavras com que o poeta Juvenal havia de sintetizar, mais tarde, esse mesmo ideal de cultura. Cabe-lhe, por isso, com toda a propriedade, o nome de humanitas e compreende-se bem que as artes, que a forman, sejam designadas por artes humanae, ou artes ingenuae, ou artes liberales.

Dos três ramos apontados, é evidente que o primado pertence às letras, visto serem elas, com as quatro matérias que abrangem - gramática, retórica, filosofia e poesia -, o alimento por excelência da cultura do espírito. Por isso mesmo, recebem estas matérias o nome de optimae artes e chegam a tomar para si a designação, já apontada, de artes ingenuae ou artes liberales, que propriamente, e genericamente, cabe ao conjunto dos três ramos da humanitas.

Mas o que importa ao nosso caso é que Cícero, embora se refira às letras, no começo do Exórdio, não pensa unicamente na instrução literária, pois está dominado pela ideia de uma ampla cultura, em que todas as partes se entrelaçam e se conjugam intimamente para benefício do homem; e, se bem que o não diga expressamente, decerto quer insinuar que só essa cultura, ampla e tipicamente humana, pode convir à formação do verdadeiro orador. 1

As letras, em geral, e a poesia, muito em particular, são indispensáveis a Cícero como meio de cultivar e repousar o espírito; como fonte de inspiração; como incitamento para enfrentar os trabalhos e perigos do dia-a-dia; por the prometerem a glória e o renome ambicionados. 2 Elas são, em suma, um manancial inesgotável de virtudes.

Mas, para isso, força é que essa mesma cultura (doctrina) busque o apoio da perfeição moral ingénita. Cícero reconhece ${ }^{3}$, como não podia deixar de ser, a transcendência desta última; admite mesmo que, em muitos casos, uma boa natureza, uma índole virtuosa, pode conduzir mais depressa à glória do que a cultura sem o dom natural, mas entende, apesar disso, que, quando se conjugam no mesmo homem uma virtude natural e uma cultura metodicamente adquirida (studia ac disciplina), por força resulta desta união um produto espiritual

1 Isto é o orador eloquens, contrariamente ao simples disertus: cf. Orator, IV, 18.

2 Cf. cap. VI.

3 Cap. VII. 
sui generis, qualquer coisa de brilhante e de singular. A comprová-lo aí está toda uma longa galeria de ilustres romanos, onde não faltam Cipiões, nem Lélios, nem Fúrios, nem Catões 1.

Contudo, ao orador consumado-eloquens - não bastam o talento natural (ingenium) e a cultura adquirida (ratio): é-lhe necessária, também, a prática (exercitatio). Eis aqui, afinal, os três elementos que, na concepção antiga, se consideravam imprescindíveis para o perfeito orador 2 .

À primeira vista, dir-se-ia que a indicação destes três elementos, como necessários à formação oratória, nada tem de particular; por isso mesmo podem parecer intuitivos. De facto, como se poderia conceber um perfeito orador a quem não faltasse o talento, mas em quem minguassem os conhecimentos teóricos e a prática indispensável? Como se havia de imaginar um bom orador que fosse rico de exercício e cultura, mas pobre de dons naturais? $\mathrm{O}$ que, porém, se nos afigura meramente intuitivo, cresce de valor e significado, quando sabemos que a tríplice virtude do orador integral, isto é, engenho (ingenium), experiência (exercitatio dicendi) e saber (ratio), representa algo de substancial na doutrinação literária antiga. É que desta doutrinação estava profundamente excluída a ideia de talento inculto, de ignorante genial que o Romantismo chegou a formular e preconizar. Prestava-se culto, evidentemente, ao brilho e ao prestígio dos dons naturais, mas juntava-se-lhes, como elementos de consistência, como forças permanentemente vivificadoras, a posse imprescindível de conhecimentos teóricos e a lição da experiência.

$\mathrm{O}$ que se diz do orador, o mesmo é dizê-lo do poeta. Todavia, poderá pôr-se uma reserva a este respeito. É que não devemos esquecer que a Antiguidade Clássica formulou uma opinião largamente divulgada: nascuntur poetae, funt oratores uos poetas nascem, os oradores fazem-se.»

Embora este aforismo nos apresente o poeta como um produto directo da natureza, e o orador, ao contrário, como um simples fruto do exercício, isso deverá explicar-se, antes de mais, pela ideia de que, no poeta, o génio, o talento natural é a virtude por excelência; e deve explicar-se, também, pelo prestígio multissecular da poesia, em que a tradição helénica via uma dádiva dos deuses. A comprová-lo aí está o poeta mítico Anfíon a mover, só com os sons harmoniosos da sua

1 Vd. notas 3, 4, 5, 6 à tradução.

2 Vd. início do texto da p. I2, e Quintiliano, Da formaçăo do orador, III, V, 1. 
lira, as pedras para a construção das muralhas da cidade de Tebas; aí está Orfeu a amansar as feras com o seu canto e a aplacar o monstruoso cão das três cabeças, Cérbero, e as próprias Fúrias, quando descia aos Infernos, em busca de Eurídice; aí está Énio a afirmar que os poetas são sagrados, «pois dir-se-ia que nos foram confiados por algum dom ou mercê dos deuses». 1 Mas se o poeta se apresentava aos olhos dos Antigos como que inspirado «por uma espécie de bafejo divino», isso não significava, porém, que ele devesse desprezar a cultura, que lhe alimenta a inspiração, nem tão pouco pôr de lado o exercício, que the estimula e aprimora o engenho.

Demais, importa reconhecer que a poesia antiga não é inteiramente autónoma de outros géneros literários, que largamente dependiam do exercício e da cultura. Um deles é, precisamente, a eloquência, da qual já Homero foi mestre, e a tal ponto que, desde muito cedo, se extraíram das duas epopeias, Iliada e Odisseia, tipos ou paradigmas de orador. ${ }^{2}$ Mas, afora a influência que a poesia recebe dos géneros mais ou menos eruditos, mais ou menos resultantes da cultura e da prática adquiridas, ela é por si mesma, segundo o pensamento antigo, um género literário a que não pode faltar uma essência erudita, nem tão-pouco uma prática animadora. Quer isto dizer que não existe arte poética, por mais genial que seja, que possa ignorar a cultura e o exercício. É afinal, como herdeiro desta concepção que o nosso Camões, no final do canto X da Epopeia (estância 154, vv. 5-8), há-de ainda dizer:

Nem me falta na vida honesto estudo ${ }^{3}$
com longa experiência misturado,
nem engenho, que aqui vereis presente,
cousas que juntas se acham raramente.

1 Vd. cap. VIII e Camões, Os Lusiadas, VII, 29, 5-7.

2 A título de exemplo - de resto bem conhecido - , recordaremos a figura do velho Nestor (Ilíada, I, 48-49), «o orador harmonioso dos Pílios», de cuja boca «brotavam palavras mais doces que o mel».

3 O sublinhado é nosso. 


\section{O conceito de glória.}

Cícero termina o seu discurso com um rasgado elogio à ambição de glória, dessa mesma glória terrena que ele, em circunstâncias bem diferentes da sua vida, há-de mais tarde condenar no Da república ( $O$ Sonho de Cipião), 1 e que é, no fim de contas, apregoada e imortalizada pelas próprias letras em geral.

A ambição de glória é, e foi sempre, uma fonte de heroísmo. Desenvolvendo este conceito, Cícero invoca perante os juízes várias figuras de generais e homens de Estado para quem a esperança de glorificação foi impulso de notáveis façanhas e que, por isso mesmo, se não cansaram de honrar os escritores e, principalmente, os poetas. É deste número Alexandre Magno, da Macedónia, que invejou Aquiles por este ter encontrado em Homero o pregoeiro dos seus feitos; ${ }^{2}$ são deste número Pompeio Magno e Sila. 3

Não se reduz, todavia, a estes exemplos o conceito em que o Orador tenta insistir. Vai mais longe, para que os juízes compreendam bem tudo quanto às letras se deve e, particularmente, à poesia, e dêem a Árquias toda a importância que ao seu talento cumpre dar. 4 É que os poetas ajudam a satisfazer esse amor da glória, como aspiração comum de todos os homens: «todos nós somos atraídos pelo desejo

1 Como já se disse, a Defesa de Árquias foi proferida em 62 a.C., quando Cícero, que fora cônsul no ano anterior e havia desmantelado a conspiração de Catilina, se encontrava no auge da sua carreira pública. O tratado Da república, porém, foi composto entre 54 e 51, quando o Orador, após um exílio no Oriente (58-57) para escapar à perseguição de Clódio, se encontrava já numa posição política francamente secundária. Vd. M. H. DA Rocha Pereira, Romana. Antologia da cultura latina. Coimbra, I.E.C., 1986, p. 44 sqq.

2 Reflexos deste passo encontram-se em Camões, Os Lusiadas, V, 93, 1-4:

Não tinha em tanto os feitos gloriosos

de Aquiles, Alexandro, na peleja,

quanto de quem o canta os numerosos

versos: isso só louva, isso deseja.

E no final do Poema $(X, 156,7-8)$ :

De sorte que Alexandro em vós se veja

sem d̀ dita de Aquiles ter enveja.

3 Cap. X.

4 Vd., contudo, nota 1 da p. 340 
de fama e são os mais valentes quem mais se deixa guiar pelo amor da glória». 1

E, uma vez mais, ocorrem os exemplos: são os próprios filósofos que escrevem sobre a glória e que, dizendo desprezá-la, sempre vão pondo o seu nome nos livros em que o fazem; é Décimo Bruto que orna com versos de Ácio as portas dos templos e os monumentos erigidos em sua honra; é Fúlvio que consagra às Musas os despojos bélicos; é, finalmente, o próprio Cícero que vê já a sua glória assegurada pelo poema que Árquias lhe está a preparar. ${ }^{2}$

Impõe-se-nos, nesta altura, uma reflexão: se este amor da glória, que Cícero abertamente proclama, não será um sentimento inferior, baixamente egoísta. A resposta é-nos dada pelo próprio Cícero, que, logo a seguir, demonstra haver nesse instinto algo de elevado, de espiritual: é que, amando a glória, os homens de acção ficam presos à ideia de que alguma coisa ficará para além de si mesmos, de que nem tudo se extinguirá com a sua existência terrena. 3 Amar a glória é, pois, segundo ele, um sentimento construtivo, pois para esses mesmos homens o desejo de renome, por mais vivo que seja, se não separa do interesse nacional, e, com a sua própria glória, também a Pátria se glorifica.

Será com Camões épico, em quem tantas vezes o «amor da pátria, não movido de prémio vil, mas alto e quase eterno» e o desejo de imortalidade pelas letras andam a par (e.g. I, est. 9, vv. 6-8, e est. 10, vv. 1-4), que daremos por findas estas considerações:
Quão doce é o louvor e a justa glória dos próprios feitos, quando são soados!
Qualquer nobre trabalha que em memória vença ou iguale os grandes já passados. As envejas da ilustre e alheia história fazem mil vezes feitos sublimados. Quem valerosas obras exercita, louvor alheio muito o esperta $e$ incita. ${ }^{4}$

\footnotetext{
Cap. X.

Mas que, como já se disse (vd. nota 1 da p.340), não chegou a concluir. Cap. XII.

Os Lusiadas, V, 92.
} 


\section{T. CICERONIS}

PRO A. LICINIO ARCHIA POETA ORATIO

VI. Quaere argumenta, si quae potes: numquam enim hic neque suo neque amicorum iudicio reuincetur.

Quaeres a nobis, Gratti, cur tanto opere hoc homine delectemur. Quia suppeditat nobis, ubi et animus ex hoc forensi strepitu reficiatur et aures conuicio defessae conquiescant. An tu existimas aut suppetere nobis posse, quod quotidie dicamus in tanta uarietate rerum, nisi animos nostros doctrina excolamus, aut ferre animos tantam posse contentionem, nisi eos doctrina eadem relaxemus? Ego uero fateor me his studiis esse deditum. Ceteros pudeat, si qui ita se litteris abdiderunt, ut nihil possint ex iis neque ad communem adferre fructum neque in aspectum lucemque proferre; me autem quid pudeat, qui tot annos ita uiuo, iudices, ut a nullius umquam me tempore aut commodo aut otium meum abstraxerit aut uoluptas auocarit aut denique

VI. Procura argumentos, os que puderes, pois nunca este meu cliente será refutado nem pela sua opinião, nem pela dos amigos.

Perguntar-me-ás, Grátio, porque me agrada tanto este homem. $E$ É que ele me fornece os meios com que refazer o espirito deste tumultuar do foro, e repousar os ouvidos cansados das invectivas. Porventura, pensas ou que poderíamos ter matéria abundante para os discursos diários, em tamanha variedade de processos, se não buscássemos nas' letras a cultura do espírito, ou que esse mesmo espirito poderia suportar tão grande contensão, se com essas mesmas letras lhe não proporcionássemos um merecido repouso? A verdade é que, no que me toca, confesso ter-me consagrado a estes estudos. Quanto aos demais, podem eles envergonhar-se, se os há que se tenham embrenhado nas letras sem conseguir extrair delas nada que aproveite aos outros ou que exponham d̀ vista e à luz do dia; eu, porém, de que hei-de envergonhar-me, eu que vivo há tantos anos de tal modo, juizes, que, sempre que se tem tratado de situações dificeis ou dos interesses de alguém, jamais o desejo de repouso me desviou, ou as solicitações do prazer me distraíram, ou, em suma, a von- 
somnus retardarit? Quare quis tandem me reprehendat, aut quis mihi iure suscenseat, si, quantum ceteris ad suas res obeundas, quantum ad festos dies ludorum celebrandos, quantum ad alias uoluptates et ad ipsam requiem animi et corporis conceditur temporum, quantum alii tribuunt tempestiuis conuiuiis, quantum denique alueolo, quantum pilae, tantum mihi egomet ad haec studia recolenda sumpsero? Atque hoc eo mihi concedendum est magis, quod ex his studiis haec quoque crescit oratio et facultas, quae, quantacumque in me est, numquam amicorum periculis defuit. Quae si cui leuior uidetur, illa quidem certe, quae summa sunt, ex quo fonte hauriam, sentio. Nam, nisi multorum praeceptis multisque litteris mihi ab adulescentia suasissem nihil esse in uita magno opere expetendum nisi laudem atque honestatem, in ea autem persequenda omnes cruciatus corporis, omnia pericula mortis atque exilii parui esse ducenda, numquam me pro salute uestra in tot ac tantas dimicationes atque in hos profligatorum hominum quotidianos impetus obiecissem. Sed pleni omnes sunt libri,

tade de dormir me atrasou? Por isso, quem, no fim de contas, me pode censurar ou quem, de direito, pode agastar-se comigo, se todo o tempo que aos demais se concede para atenderem aos seus próprios interesses, para celebrarem as solenidades dos jogos públicos ${ }^{1}$, para outros prazeres ou para simples repouso da alma e do corpo, se todo o tempo que outros destinam a demorados festins, em suma, que eles repartem pela mesa de jogo 2 e pelo jogo da péla, eu, pela minha parte, o reservar para me consagrar a estes estudos? Além disso, força é que tal concessão me seja feita, tanto mais que é graças a esses estudos que também se desenvolve esta minha faculdade oratória, que, na proporção das minhas forças, nunca aos amigos faltou na hora do perigo. Se a alguém ela se afigurar de fraco peso, pelo menos sei bem de que fonte hei-de haurir outros benefícios que são deveras importantes. É que se os ensinamentos de tantos mestres e se tantos escritos me não tivessem persuadido, desde a juventude, de que na vida nada se deve desejar tão vivamente como a glória e o prestígio, e que, para alcançá-los, todos os tormentos físicos, todos os perigos de morte e exílios devem ser tidos em menospreço, jamais eu me teria exposto, pela vossa salvação, a tantas e tão duras provas, e a estas investidas diárias de homens depravados. Mas destes conceitos estão cheios todos os livros, estão cheias as máximas dos filósofos, estão cheios 
plenae sapientium uoces, plena exemplorum uetustas; quae iacerent in tenebris omnia, nisi litterarum lumen accederet. Quam multas nobis imagines non solum ad intuendum, verum etiam ad imitandum fortissimorum uirorum expressas scriptores et Graeci et Latini reliquerunt! Quas ego mihi semper in administranda re publica proponens animum et mentem meam ipsa cogitatione hominum excellentium conformabam.

VII. Quaeret quispiam: "Quid? illi ipsi summi uiri, quorum uirtutes litteris proditae sunt, istane doctrina, quam tu effers laudibus, eruditi fuerunt?" Difficile est hoc de omnibus confirmare; sed tamen est certum, quod respondeam. Ego multos homines excellenti animo ac uirtute fuisse sine doctrina, et naturae ipsius habitu prope diuino per se ipsos et moderatos et graues exstitisse fateor; etiam illud adiungo, saepius ad laudem atque uirtutem naturam sine doctrina quam sine natura ualuisse doctrinam. Atque idem ego hoc contendo, cum ad naturam eximiam et illustrem accesserit ratio quaedam conformatioque doctrinae, tum illud nescio quid praeclarum ac singulare solere exsistere.

os exemplos da Antiguidade; e todos eles jazeriam nas trevas sem o concurso das letras com sua luz. Quantos retratos perfeitos de varões tão denodados nos não deixaram os escritores, tanto gregos como latinos, não apenas para contemplar, senão também para imitar! Com eles sempre diante dos olhos no exercício das minhas funções públicas, eu moldava o meu sentir e pensar com a só evocação de homens notáveis.

VII. Perguntará alguém: "Como assim? Aqueles mesmos altos varões, cujas virtudes as letras revelaram, acaso possuíram essa cultura que tu exaltas com teus louvores?» Difícil é assegurá-lo a respeito de todos; é certo, no entanto, o que vou responder. Confesso que muitos homens houve de excelsa indole e virtude, embora sem cultura, e que foram de si mesmos regrados e austeros por uma quase divina disposição da própria natureza; até acrescento o seguinte: é que mais vezes concorreu para a glória e para a virtude o dom natural sem a cultura do que a cultura sem o dom natural. Mas de igual modo sustento esta ideia: que, quando uma certa instrução e formação cultural se juntam a uma natureza superior e brilhante, logo surge, em regra, qualquer coisa de notável e de 
Ex hoc esse hunc numero, quem patres nostri uiderunt, diuinum hominem, Africanum; ex hoc C. Laelium, L. Furium, moderatissimos homines et continentissimos; ex hoc fortissimum uirum et illis temporibus doctissimum, M. Catonem illum senem; qui profecto si nihil ad percipiendam colendamque uirtutem litteris adiuuarentur, numquam se ad earum studium contulissent. Quod si non hic tantus fructus ostenderetur, et si ex his studiis delectatio sola peteretur, tamen, ut opinor, hanc animi remissionem humanissimam ac liberalissimam iudicaretis. Nam ceterae neque temporum sunt neque aetatum omnium neque locorum; at haec studia adulescentiam alunt, senectutem oblectant, secundas res ornant, aduersis perfugium ac solacium praebent, delectant domi, non impediunt foris, pernoctant nobiscum, peregrinantur, rusticantur. Quodsi ipsi haec neque attingere neque sensu nostro gustare possemus, tamen ea mirari deberemus, etiam cum in aliis uideremus.

V1II. Quis nostrum tam animo agresti ac duro fuit, ut Rosci morte nuper non commoueretur? qui cum esset senex mortuus, tamen propter

singular. Está neste caso o divino homem que nossos pais conheceram, o Africano ${ }^{3}$; deste número são Gaio Lélio ${ }^{4}$ e Lúcio Fúrio ${ }^{5}$, homens de grande moderação e temperança; deste número ainda o famoso Marco Catão, o Velho 6 , homem de tão grande vigor e de tão grande cultura para o seu tempo: se as letras em nada os ajudassem na áquisição e cultivo da virtude, nunca evidentemente se teriam aplicado a estudá-las.

$E$ mesmo que não surgisse tamanho fruto e que em tais estudos apenas se buscasse o prazer, ainda assim, quero crê-lo, deverieis julgar esta recreação do espírito bem humana e bem liberal. É que as outras nem são de todos os momentos, nem de todas as idades, nem de todos os. lugares, ao passo que estes estudos alimentam a mocidade e recreiam $a$ velhice; são o ornamento da ventura e dão refúgio e consolação na desventura; deleitam-nos em casa e não nos embaraçam fora dela; pernoitam connosco, seguem-nos em viagem, acompanham-nos no campo ${ }^{7}$.

Se, portanto, nós mesmos não lográssemos entendê-los nem apreciá-los com o nosso sentir, ainda assim deveríamos admirá-los, mesmo quando os víssemos nos outros.

VIII. Qual de nós teve ânimo tão rude e insensivel que há pouco se não impressionasse com a morte de Róscio ${ }^{8}$ ? É certo que morreu 
excellentem artem ac uenustatem uidebatur omnino mori non debuisse. Ergo ille corporis motu tantum amorem sibi conciliarat a nobis omnibus; nos animorum incredibiles motus celeritatemque ingeniorum neglegemus? Quotiens ego hunc Archiam vidi, iudices (utar enim uestra benignitate, quoniam me in hoc nouo genere dicendi tam diligenter attenditis), quotiens ego hunc uidi, cum litteram scripsisset nullam, magnum numerum optimorum uersuum de is ipsis rebus, quae tum agerentur, dicere ex tempore, quotiens reuocatum eamdem rem dicere commutatis uerbis atque sententiis! Quae uero accurate cogitateque scripsisset, ea sic uidi probari, ut ad ueterum scriptorum laudem perueniret. Hunc ego non diligam, non admirer, non omni ratione defendendum putem? Atque sic a summis hominibus eruditissimisque accepimus, ceterarum rerum studia ex doctrina et praeceptis et arte constare, poetam natura ipsa ualere et mentis uiribus excitari et quasi diuino quodam spiritu inflari. Quare suo iure noster ille Ennius "sanctos" appellat poetas, quod quasi deorum aliquo dono atque

velho, mas parecia, pela excelência da sua arte e pelo encanto pessoal, que não deveria mesmo ter morrido. Assim, com o só exercício do corpo ganhara ele de todos nós tamanha afeição; e nós havemos de desprezar os extraordinários exercícios dos espiritos e a agilidade dos talentos? Quantas vezes eu não vi este nosso Árquias, ó juizes - valer-me-ei, realmente, da vossa benignidade, já que com tanta atenção me escutais neste novo estilo oratório - , quantas vezes eu o vi, sem ter escrito uma única letra, improvisar grande número de excelentes versos acerca de factos que decorriam sob os nossos olhos! Quantas vezes, instado a bisar, o não vi eu expor o mesmo tema por outras palavras e conceitos! E aquilo que houvesse escrito com esmero e reflexão, por tal forma o vi aceite, que o seu autor alcançava a glória dos antigos escritores 9 . Um homem assim, não hei-de eu prezá-lo, não hei-de admirá-lo, não hei-de pensar que importa defendê-lo por todos os meios?

De resto, aprendemos com os homens mais notáveis e eruditos que os estudos das outras matérias se fundam no ensino, nas regras, na teoria, ao passo que o poeta tem valor pela sua própria natureza 10 e é estimulado pelas forças intelectuais e é inspirado, digamos assim, por uma espécie de bafejo divino. É por isso que o nosso famoso Énio 11, com todo o seu direito, chama sagrados aos poetas: pois dir-se-ia que nos 
munere commendati nobis esse uideantur. Sit igitur, iudices, sanctum apud uos, humanissimos homines, hoc poetae nomen, quod nulla umquam barbaria uiolauit. Saxa et solitudines uoci respondent, bestiae saepe immanes cantu flectuntur atque consistunt; nos instituti rebus optimis non poetarum uoce moueamur? Homerum Colophonii ciuem esse dicunt suum, Chii suum uindicant, Salaminii repetunt, Smyrnaei vero suum esse confirmant, itaque etiam delubrum eius in oppido dedicauerunt; permulti alii praeterea pugnant inter se atque contendunt.

IX. Ergo illi alienum, quia poeta fuit, post mortem etiam expetunt; nos hunc uiuum, qui et uoluntate et legibus noster est, repudiabimus, praesertim cum omne olim studium atque omne ingenium contulerit Archias ad populi Romani gloriam laudemque celebrandam? Nam et Cimbricas res adulescens attigit et ipsi illi C. Mario, qui durior ad haec studia uidebatur, iucundus fuit. Neque enim quisquam est tam auersus a Musis, qui non mandari uersibus aeternum suorum laborum facile praeconium patiatur. Themistoclem illum, summum Athenis

foram confiados por algum dom e mercê dos deuses. Seja, pois, sagrado perante vós, ó juizes, homens de tão humana cultura, este nome de poeta que jamais qualquer barbárie profanou. Os rochedos e as solidões respondem à sua voz ${ }^{12}$; não raro as feras se dobram ao seu canto e param 13 ; e nós, instruídos nas melhores disciplinas, não havemos de nos impressionar com a voz dos poetas? Cólofon 14 diz que Homero é seu cidadão; Quios reclama-o como seu; Salamina exige-o; Esmirna, por seu turno, assegura que ele lhe pertence e até um santuário lhe dedicou, na cidadela. Além disso, lutam entre si e porfiam por ele muitíssimas outras cidades.

IX. Assim, pois, almejam elas um estranho até depois da morte, só porque foi poeta 15 ; e nós havemos de repudiar um vivo, que é nosso por sua vontade e pelas leis, mormente quando Árquias já um dia aplicou todo o seu ardor e todo o seu talento à celebração da fama e glória do povo romano? Jovem ainda, inspirou-se nas Guerras Címbricas $16 e$ até agradou ao ilustre Gaio Mário, que parecia demasiado rude para tais ardores 17.

Ninguém é, na verdade, tão avesso às Musas que se não resigne a confiar à poesia o pregão eterno dos seus feitos. O grande Temístocles ${ }^{18}$, 
uirum, dixisse aiunt, cum ex eo quaereretur, quod acroama aut cuius uocem libentissime audiret: "eius, a quo sua uirtus optime praedicaretur". Itaque ille Marius item eximie L. Plotium dilexit, cuius ingenio putabat ea, quae gesserat, posse celebrari. Mithridaticum uero bellum, magnum atque difficile et in multa uarietate terra marique uersatum, totum ab hoc expressum est; qui libri non modo L. Lucullum, fortissimum et clarissimum uirum, uerum etiam populi Romani nomen illustrant. Populus enim Romanus aperuit Lucullo imperante Pontum et regiis quondam opibus et ipsa natura et regione uallatum; populi Romani exercitus eodem duce non maxima manu innumerabilis Armeniorum copias fudit; populi Romani laus est urbem amicissimam Cyzicenorum eiusdem consilio ex omni impetu regio atque totius belli ore ac faucibus ereptam esse atque seruatam; nostra semper feretur et praedicabitur L. Lucullo dimicante, cum interfectis ducibus depressa hostium classis est, incredibilis apud Tenedum pugna illa naualis; nostra sunt tropaea, nostra monumenta, nostri triumphi. Quae

insigne varão de Atenas, ao ser-lhe perguntado qual o concerto ou qual a voz que ouviria de melhor vontade, respondeu, segundo se diz, que era «a de quem melhor apregoasse o seu valor». Foi também a razão por que o grande Mário ${ }^{19}$ quis tanto a Lúcio Plócio 20, cujo talento ele julgava capaz de lhe celebrar as façanhas.

E a campanha contra Mitridates 21 , grande e dificil e desenrolada por terra e mar com fortuna vária, foi por Árquias inteiramente descrita; e a obra respectiva não só ilustra Lúcio Luculo 22 , varão tão esforçado e preclaro, mas também o nome do povo romano. Foi, na verdade, o povo romano quem abriu, sob o comando de Luculo, a passagem do Ponto ${ }^{23}$, barrado outrora pela potência dos reis, pela própria natureza e pela posição geográfica; foi o exército do povo romano, sob o comando do mesmo general, quem desbaratou com reduzido contingente as tropas inúmeras dos Arménios 24 ; é glória ainda do povo romano que a fidelissima cidade dos Cizicenos 25, por iniciativa do mesmo, tenha sido liberta $e$ preservada de quaisquer incursões dos reis e das fauces hiantes de toda uma guerra 26; será sempre, também, cantada e apregoada, como façanha nossa, aquela incrível batalha naval de Ténedos 27, em que Lúcio Luculo pelejou e em que foram mortos os almirantes e afundada a esquadra inimiga. São, pois, nossos 28 os troféus, nossos os monumentos, nossos 
quorum ingeniis efferuntur, ab iis populi Romani fama celebratur. Carus fuit Africano superiori noster Ennius; itaque etiam in sepulcro Scipionum putatur is esse constitutus ex marmore; cuius laudibus certe non solum ipse, qui laudatur, sed etiam populi Romani nomen ornatur. In caelum huius proauus Cato tollitur: magnus honos populi Romani rebus adiungitur. Omnes denique illi Maximi, Marcelli, Fuluii non sine communi omnium nostrum laude decorantur.

X. Ergo illum, qui haec fecerat, Rudinum hominem, maiores nostri in civitatem receperunt; nos hunc Heracliensem multis ciuitatibus expetitum, in hac autem legibus constitutum de nostra ciuitate eiciamus?

Nam, si quis minorem gloriae fructum putat ex Graecis uersibus percipi quam ex Latinis, uehementer errat, propterea quod Graeca leguntur in omnibus fere gentibus, Latina suis finibus, exiguis sane, continentur. Quare, si res eae, quas gessimus, orbis terrae regionibus definiuntur, cupere debemus, quo manuum nostrarum tela peruenerint,

os triunfos. E é, afinal, a glória do povo romano o que celebram aqueles cujos talentos enaltecem esses feitos.

Ao Primeiro Africano 29 foi caro o nosso Énio ${ }^{30}$, e até se julga que o esculpiram em mármore no sepulcro dos Cipiões; mas os seus louvores, por certo, não honram apenas o proprio homem que é louvado, senão também o nome do povo romano. Catão ${ }^{31}$, bisavô do actual, é erguido aos céus; tanto basta para acrescer grande lustre aos feitos do nosso povo. Enfim, todos esses famosos Máximos, Marcelos, Fúlvios 32 não recebem honras sem o comum louvor de todos nós.

X. E, afinal, quem tais feitos descreva, o homem de Rúdias 33, foi admitido como cidadão pelos nossos maiores; e nós a este homem de Heracleia, reclamado por tantas cidades, legalmente estabelecido nesta, havemos de excluí-lo da cidadania romana?

$\hat{E}$ que, se alguém supõe que se colhe dos versos grègos menos fruto de glória que dos latinos, redondamente se engana, porque as obras gregas são lidas em quase todas as nações, ao passo que as latinas se restringem ao seu território, sem dúvida pequeno ${ }^{34}$. E por isso mesmo, se as nossas façanhas têm por limite o próprio orbe terrestre, devemos desejar que, até onde chegarem as tropas e as armas dos nossos, ai mesmo 
eodem gloriam famamque penetrare, quod cum ipsis populis, de quorum rebus scribitur, haec ampla sunt, tum iis certe, qui de uita gloriae causa dimicant, hoc maximum et periculorum incitamentum est et laborum. Quam multos scriptores rerum suarum magnus ille Alexander secum habuisse dicitur! Atque is tamen, cum in Sigeo ad Achillis tumulum adstitisset: "O fortunate", inquit, "adulescens, qui tuae uirtutis Homerum praeconem inueneris!" Et uere. Nam, nisi Ilias illa exstitisset, idem tumulus, qui corpus eius contexerat, nomen etiam obruisset. Quid? noster hic Magnus, qui cum uirtute fortunam adaequauit, nonne Theophanem Mytilenaeum, scriptorem rerum suarum, in contione militum ciuitate donauit, et nostri illi fortes uiri, sed rustici ac milites dulcedine quadam gloriae commoti quasi participes eiusdem laudis magno illud clamore approbauerunt? Itaque, credo, si ciuis Romanus Archias legibus non esset, ut ab aliquo imperatore ciuitate donaretur, perficere non potuit! Sulla, cum Hispanos et Gallos donaret, credo, hunc petentem repudiasset; quem nos in contione uidimus cum ei libellum malus poeta de populo subiecisset, quod

penetrem glória e fama: pois não só tais valores se impõem aos mesmos povos, cuja história se relata, mas são eles mesmos, por certo, para aqueles que arriscam a vida pela glória, o maior incitamento aos perigos $e$ aos trabalhos.

Quantos cronistas dos seus feitos esse grande Alexandre não teve consigo, segundo se conta 35! E, contudo, ao passar no Sigeu 36, à beira do túmulo de Aquiles, exclamou: "Ditoso jovem, que encontraste em Homero o pregoeiro do teu valor 37!» E com razão: se não tivesse existido a famosa Ilíada, o mesmo túmulo que lhe cobrira o corpo ter-lhe-ia também sepultado o nome. Pois quê? Este nosso Magno 38, que à valentia igualou a fortuna, não deu título de cidadão, numa assembleia de soldados, a Téffanes de Mitilene ${ }^{39}$, narrador dos seus feitos? E esses nossos bravos homens, embora rústicos e simples soldados, por força de certo encanto que há na glória, não aplaudiram o acto com grande clamor, como se participassem do mesmo galardão?

Por isso, estou mesmo a ver 40 que, se Arquias não fosse cidadão romano pelas leis, não teria conseguido que algum general lhe concedesse o título... Sila 41, que o dera a Hispanos e Gauleses 42, teria rejeitado, evidentemente, a petição deste homem... O Sila, a quem nós vimos, numa assembleia, quando um vulgar poetastro lhe estendeu um folheto, por 
epigramma in eum fecisset tantummodo alternis uersibus longiusculis, statim ex iis rebus, quas tum uendebat, iubere ei praemium tribui, sed ea condicione, ne quid postea scriberet. Qui sedulitatem mali poetae duxerit aliquo tamen praemio dignam, huius ingenium et uirtutem in scribendo et copiam non expetisset? Quid? a Q. Metello Pio, familiarissimo suo, qui ciuitate multos donauit, neque per se neque per Lucullos impetrauisset? qui praesertim usque eo de suis rebus scribi cuperet, ut etiam Cordubae natis poetis, pingue quiddam sonantibus atque peregrinum, tamen aures suas dederet.

XI. Neque enim est hoc dissimulandum, quod obscurari non potest, sed prae nobis ferendum: trahimur omnes studio laudis, et optimus quisque maxime gloria ducitur. Ipsi illi philosophi etiam in iis libellis, quos de contemnenda gloria scribunt, nomen suum inscribunt; in eo ipso, in quo praedicationem nobilitatemque despiciunt, praedicari de se ac nominari uolunt. Decimus quidem Brutus, summus uir et imperator, Acci, amicissimi sui, carminibus templorum ac monumentorum

ter composto em sua honra apenas um epigrama em dísticos, mandar logo dar-lhe, dos bens que então trazia em hasta pública, uma recompensa, mas com a condição de não tornar a escrever. Quem, mesmo assim, julgou digno de algum prémio o zelo de um mau poeta, não se teria agradado do engenho deste e do seu vigor e abundância de estilo? Como assim? O título de cidadão nem pelos seus méritos nem por influência dos Luculos o teria ele obtido de Quinto Metelo, o Pio 43, seu intimo amigo, que a tantos o concedeu? Metelo tanto ambicionava, aliás, que se escrevesse dos seus feitos, que até dava atenção a poetas cordoveses, de estilo um tanto empolado e de sotaque estrangeiro 44.

XI. É que se não deve dissimular um sentimento que não é possivel manter na sombra, mas de que importa, antes, fazer alarde: é que todos nós somos solicitados pelo amor da fama e são os mais dotados quem mais se deixa guiar pelo desejo de glória. Os próprios filosofos; até naqueles opúsculos que escrevem sobre o desprezo da glória, inscrevem o seu nome: no mesmo lugar onde desdenham do elogio e da fama, eles querem ser enáltecidos e nomeados. Assim, Décimo Bruto 45, varão e general eminente, ornou a entrada de templos e monumentos, que erguera, 
aditus exornauit suorum. Iam uero ille, qui cum Aetolis Ennio comite bellauit, Fuluius, non dubitauit Martis manubias Musis consecrare. Qua re, in qua urbe imperatores prope armati poetarum nomen et Musarum delubra coluerunt, in ea non debent togati iudices a Musarum honore et a poetarum salute abhorrere.

Atque, ut id libentius faciatis, iam me uobis, iudices, indicabo, et de meo quodam amore gloriae nimis acri fortasse, uerumtamen honesto uobis confitebor. Nam, quas res nos in consulatu nostro uobiscum simul pro salute urbis atque imperii et pro uita ciuium proque uniuersa re publica gessimus, attigit hic uersibus atque inchoauit. Quibus auditis, quod mihi magna res et iucunda uisa est, hunc ad perficiendum adhortatus sum. Nullam enim uirtus aliam mercedem laborum periculorumque desiderat praeter hanc laudis et gloriae; qua quidem detracta, iudices, quid est quod in hoc tam exiguo uitae curriculo et tam breui tantis nos in laboribus exerceamus? Certe, si nihil animus praesentiret in posterum, et si, quibus regionibus uitae spatium cir-

com versos de Ácio 46, seu íntimo amigo. Demais, aqueloutro, que combateu contra os Etólios, com Énio 47 por companheiro, Fúlvio 48, não hesitou consagrar às Musas as manúbias de Marte 49. Por isso, numa cidade em que os generais, quase sem tirar as armas, honraram o nome dos poetas e os santuários das Musas, não devem os juizes de toga 50 ter relutância em honrar as Musas e salvaguardar os poetas.

E para que o façais de melhor grado, vou já abrir-me convosco, juizes, e confessar-vos, por assim dizer, o meu amor pela glória, demasiado ardente, talvez, mas, em todo o caso, honesto. De facto, a acção por mim desenvolvida, com o vosso apoio, durante o meu consulado, em prol da salvaguarda desta cidade e do Império, e na defesa da vida dos cidadãos e a favor do Estado inteiro 51, inspirou este meu constituinte, que já começou a celebrá-la num poema 52. Depois de ouvir os primeiros versos, porque o cometimento se me afigurou importante e com interesse, encorajei-o a levá-lo a cabo. É que a virtude não espera nenhuma outra mercê pelos seus trabalhos e perigos que não seja a da estima e da glória. Sem essa recompensa, que outro motivo. há, juizes, para, nesta carreira tão estreita e tão curta da vida, nos mortificarmos em tão duros trabalhos? Por certo, se a alma não tivesse algum pressentimento para o futuro e se aqueles mesmos limites, que confinam o 
cumscriptum est, iisdem omnes cogitationes terminaret suas, nec tantis se laboribus frangeret neque tot curis uigiliisque angeretur, nec totiens de ipsa uita dimicaret. Nunc insidet quaedam in optimo quoque uirtus, quae noctes ac dies animum gloriae stimulis concitat atque admonet non cum uitae tempore esse dimittendam commemorationem nominis nostri, sed cum omni posteritate adaequandam.

XII. An uero tam parui animi uideamur esse omnes, qui in re publica atque in his uitae periculis laboribusque uersamur, ut, cum usque ad extremum spatium nullum tranquillum atque otiosum spiritum duxerimus, nobiscum simul moritura omnia arbitremur? An statuas et imagines, non animorum simulacra, sed corporum, studiose multi summi homines reliquerunt; consiliorum relinquere ac uirtutum nostrarum effigiem non multo malle debemus summis ingeniis expressam et politam? Ego uero omnia, quae gerebam, iam tum in gerendo spargere me ac disseminare arbitrabar in orbis terrae memoriam sempiternam. Haec vero siue a meo sensu post mortem afutura est, siue,

espaço da vida, delimitassem todos os seus pensamentos, o homem não se consumiria com tão duros trabalhos, nem se atormentaria com tantos cuidados e vigílias, nem arriscaria tantas vezes a própria vida. Ora, em todos os seres de eleição há uma certa força interior que, noite e dia, concita a alma com o estímulo da glória e a adverte de que o importante é que a lembrança do nosso nome não seja ceifada com os instantes da nossa vida, mas prolongada a toda a posteridade.

XII. Então será possivel que todos nós, que nos ocupamos de politica e destes perigos e trabalhos da existência, dêmos mostras de um espírito tão tacanho, ao ponto de pensarmos que, uma vez chegados ao termo da nossa carreira, sem termos podido respirar um pouco em paz e sossego, tudo há-de morrer juntamente connosco? Quando muitos homens eminentes se empenharam em deixar após si estátuas e retratos, representações, não da alma, mas do corpo, não devemos nós dar uma maior preferência a deixarmos atrás de nós a imagem dos nossos actos e virtudes, reproduzida e acabada pelos homens de maior talento? .Quanto a mim, todos os meus actos, já no próprio momento em que os executava, ia pensando divulgá-los e propagá-los para eterna memória do orbe terrestre. E esta recordação, quer ela deva, após a morte, escapar à minha 
ut sapientissimi homines putauerunt, ad aliquam animi mei partem pertinebit, nunc quidem certe cogitatione quadam speque delector.

Qua re conseruate, iudices, hominem pudore eo, quem amicorum uidetis comprobari cum dignitate, tum etiam uetustate, ingenio autem tanto, quantum id conuenit existimari, quod summorum hominum ingeniis expetitum esse uideatis, causa uero eius modi, quae beneficio legis, auctoritate municipii, testimonio Luculli, tabulis Metelli comprobetur. Quae cum ita sint, petimus a uobis, iudices, si qua non modo humana, uerum etiam diuina in tantis ingeniis commendatio debet esse, ut eum, qui uos, qui uestros imperatores, qui populi Romani res gestas semper ornauit, qui etiam his recentibus nostris uestrisque domesticis periculis aeternum se testimonium laudis daturum esse profitetur, estque ex eo numero, qui semper apud omnes sancti sunt habiti itaque dicti, sic in uestram accipatis fidem, ut humanitate uestra leuatus potius quam acerbitate uiolatus esse uideatur.

percep̧̧ão, quer, segundo pensam homens do maior saber, ela chegue a qualquer parte da minha alma, uma coisa é certa, é que por ora tenho um pensamento e uma esperança que me dão certo prazer.

Conservai 53 , portanto, este homem, ó juizes: a sua honradez está, aos vossos olhos, comprovada não apenas pelo prestígio, mas também pela duração das suas amizades; o seu talento é tão vasto como convém supor, a avaliar pela procura que tem da parte das mais destacadas inteligências; a sua causa, enfim, é de tal ordem, que o apoiam o favor de uma lei, a garantia de um município, o testemunho de Luculo, os registos de Metelo. Sendo assim, juizes, se algum título de recomendação, não apenas humana, senão também divina, deve haver em génios de tal grandeza, este homem - que jamais deixou de vos celebrar, a vós, aos vossos generais, aos cometimentos do povo romano, que até declara ter em mente imortalizar, pelo seu testemunho, estes perigos internos em que, ainda há pouco, tanto eu como vós nos vimos envolvidos 54 , e que pertence ao número dos que nunca deixaram de ser considerados e chamados sagrados por toda a gente - peço-vos que o tomeis sob a vossa proteç̧ão, por forma a que ele seja confortado pela vossa bondade, e não ultrajado pelo vosso rigor. 
Quae de causa pro mea consuetudine breuiter simpliciterque dixi, iudices, ea confido probata esse omnibus; quae a forensi aliena iudicialique consuetudine et de hominis ingenio et communiter de ipso studio locutus sum, ea, iudices, a uobis spero esse in bonam partem accepta, ab eo, qui iudicium exercet, certo scio.

A parte da defesa respeitante ao problema jurídico, que eu, segundo os meus hábitos, proferi com brevidade e simplicidade, estou confiante, $\delta$ juizes, que obteve a aprovação de todos vós. As palavras que pronunciei, estranhas ao foro e às praxes judiciárias, não apenas sobre o talento do meu cliente, senão também sobre os seus estudos em geral, espero que as tenhais acolhido favoravelmente. Foram-no, estou certo, por quem preside ao tribunal 55 .

\section{N O T A S}

1 Sobre os jogos romanos, veja-se o nosso artigo na Enciclopédia Verbo, s. v. «Jogos», 2.

2 Entenda-se «do jogo dos dados».

3 Públio Cornélio Cipião Emiliano, também chamado o Segundo Africano e Numantino: destruiu Cartago (146 a.C.) e Numância (133 a.C.).

4 Gaio Lélio, companheiro de armas e amigo íntimo do Africano (vide nota anterior). Modelos de soldados e de homens de letras para Cícero (como se evidencia, por exemplo, através do diálogo $\mathrm{Da}$ velhice), ambos contribuíram largamente para a difusão da cultura grega em Roma (vide Pierre Grimal, Le siècle des Scipions, Paris, 21975).

5 Cônsul em 136; amigo dos precedentes.

6 Marco Pórcio Catão, o Censor (234-149 a.C.): foi um dos mais encarniçados opositores à difusão do helenismo em Roma. Mas Cícero, que muito o admirava, deu-nos dele um retrato idealizado ( $D a$ velhice). Chegou mesmo a afirmar (ibidem I, 3; VIII, 26), ao que parece sem fundamento, que Catão, apesar da luta travada, se teria deixado vencer, em idade avançada, pelos encantos da língua e literatura gregas. Sobre o problema da difusão do helenismo em Roma vide Pierre Grimal, Le siècle des Scipions, cit. na nota 4.

7 Sobre as ideias aqui expostas por Cícero e o seu eco nos humanistas Hilário Moreira e Arnaldo Fabrício, vide F. Rebelo Gonçalves, "As humanidades clássicas e a Universidade de Coimbra": Humanitas I (1947), p. XIII e nota 1. 
8 Quinto Róscio Galo, célebre actor e mestre de declamação de Cícero, morreu por volta de 72 a.C.

9 Hipérbole retórica: no que respeita aos méritos literários de Árquias, vide p. 340 , nota 1 .

10 Cf. o antigo aforismo nascuntur poetae, fiunt oratores ("os poetas nascem, os oradores fazem-se») (vide pp. 343 sq.).

11 Célebre poeta épico e dramático, nascido em Rúdias em 239 a.C. e morto em 169 a.C. Da sua monumental epopeia - Anais - e da sua produção dramática - tragédias e comédias - apenas chegaram até nós fragmentos. Cícero, que muito o admirava, cita-o com frequência nas suas obras.

12 Segundo a mitologia, Anfíon teria movido, com os sons harmoniosos da sua lira, as pedras para a construção das muralhas da cidade de Tebas.

13 A semelhança de Anfíon (vide nota anterior), o poeta mítico Orfeu conseguia amansar as feras com a suavidade do seu canto. Teria mesmo aplacado Cérbero - monstruoso cão de três cabeças - e as próprias Fúrias, quando da sua descida aos Infernos para trazer de novo à vida sua esposa, Eurídice (cf. Camőes, Os Lusíadas VII, 29, 5-7).

14 Cícero enumera aqui algumas das cidades que disputavam a honra de serem berço de Homero. Outras eram Rodes, Argos, Atenas, Ítaca, Micenas, etc. Geralmente agrupavam-se sete nomes. Sobre essa contenda famosa na Antiguidade, veja-se W. R. Paton, The Greek Anthology, London, 1960, vol. V, pp. 335-341, em especial os epigramas 295-299; e p. 79, epigrama 102. Cf. ainda Os Lusíadas, V, $87,1-4$. Sobre a posição actual da crítica em relação à figura de Homero, leia-se o artigo respectivo de M. H. Rocha Pereira na Enciclopédia Verbo.

15 Note-se a dupla hipérbole contida nesta antítese: Homero é apresentado como um simples poeta, sem outros méritos que não fossem os de ter composto a Iliada e a Odisseia...; Árquias, como o grande pregoeiro da gesta romana! Vide p. 340 , nota 1 .

16 As guerras contra os Cimbros, que, aliados aos Teutóes, invadiram a Gália e se estenderam até ao Norte da Itália (113-101 a.C.). Foram vencidos por Gaio Mário (vide nota seguinte).

17 Em Salústio (Guerra de Jugurta, LXXXV, 32) é o próprio Gaio Mário quem afirma que não estudou a eloquência grega por ela em nada contribuir para o amor da virtude. Contudo, admirava o talento de Lúcio Plócio (vide infra, nota 20).

18 Famoso general e estadista grego, vencedor da batalha naval de Salamina (480 a.C.). A propósito deste passo do discurso, cf. Camões, Os Lusiadas, V, 93, 7-8 (referindo-se a Temístocles):

\section{E diz que nada tanto o deleitava}

como a voz que seus feitos celebrava.

19 Vide supra, notas 16 e 17.

20 Lúcio Plócio Galo, o primeiro mestre de retórica latina.

21 A terceira guerra contra Mitridates, rei do Ponto (74-63 a.C.).

22 Ilustre membro da família dos Luculos. 
23 Façanha levada a cabo entre 72 e 70 a.C.

24 Segundo consta, as tropas romanas contavam uns dez mil soldados, ao passo que as dos Arménios, aliados de Mitridates, uns duzentos mil!

25 Cízico, cidade do mar da Mármara, fiel aliada de Roma na luta contra Mitridates. Assediada pelas tropas deste rei, foi libertada pelas forças romanas comandadas por Lúcio Luculo (73 a.C.).

26 Imagem de ressonância épica para indicar uma guerra sangrenta, sem quartel (cf. Iliada X, 8, onde se fala das «enormes fauces de uma funesta guerra»).

27 Ilha da costa da Ásia Menor, em frente da Tróade, junto à qual se travaram duas batalhas navais, em 84 e em 72 a.C.

28 Note-se a anáfora (nossos... ... nossos ... nossos) que dá particular relevo aos feitos dos exércitos romanos.

29 Vencedor de Aníbal na batalha de Zama (202 a.C.); não deve ser confundido com o Segundo Africano (vide supra, nota 3).

30 Vide supra, nota 11.

31 Catão, o Censor (vide supra, nota 6), era bisavô de Catão de Útica. Note-se que a forma latina huius, que traduzimos por «do actual», poderá também intepretar-se como «do aqui presente; daquele que aqui vedes».

32 Sinédoque (plural pelo singular). Cícero quer referir-se, apenas, a três célebres generais da segunda Guerra Púnica, todos eles cantados por Énio: Quinto Fábio Máximo, Marco Cláudio Marcelo e Marco Fúlvio Nobílior.

33 Vide supra, nota 11. Note-se a antítese: Énio, que nascera numa cidade não federada, obteve o direito de cidadania (em 184 a.C.); Árquias, que é cidadão de Heracleia, cidade aliada, há-de ser expulso de Roma?!

34 Com um desassombro que ainda hoje nos surpreende, Cícero tem o arrojo de proclamar em pleno tribunal romano, na defesa de um poeta helenizado, a superioridade literária e cultural da Grécia. Estas palavras são como que uma antecipação daquelas com que Horácio viria a apregoar mais tarde (Epistolas II, I, 156-157) a vitória espiritual dos Gregos sobre os seus vencedores, os Romanos (vide p. 340).

35 Alexandre Magno, em campanha, fazia-se acompanhar de historiadores e poetas (p. ex., Nearco, Calístenes, Aristobulo, Anaxímenes, Onesícrito, Quérilo e outros), panegiristas dos seus feitos.

36 Promontório da Tróade, onde, segundo a tradição, os Gregos tinham assentado arraiais durante os dez anos da Guerra de Tróia.

37 Vide p. 345.

38 Pompeio Magno, citado neste passo em antítese com Alexandre Magno.

39 Historiador e amigo de Pompeio.

40 Ironia.

41 Lúcio Cornélio Sila, vencedor da batalha que teve por cenário a localidade de Queroneia, na Beócia, contra as tropas, em número muito superior, comandadas por Mitridates (86 a.C.).

42 Sila teria concedido o direito de cidadania a alguns habitantes de Cádis e a Aríston de Marselha. Note-se o tom de desprezo com que Cícero se lhes refere. 
43 Quinto Metelo Pio foi pretor, em 89 a.C., juntamente com Ápio Cláudio Pulcro, Lúcio Lêntulo e Públio Gabínio Capitão.

44 Curiosa referência ao estilo empolado dos poetas de Córdova, que virá, mais tarde, a ter confirmação nas tragédias de Séneca e na poesia de Lucano.

45 Décimo Júnio Bruto, cônsul em 138 a.C., recebeu o agnome de "Galego" por ter vencido os Galécios e conquistado uma grande parte da Lusitânia.

46 Poeta trágico latino (170-86 ? a.C.).

47 Vide supra, nota 11.

48 Vide supra, nota 32.

49 Isto é, «os despojos da guerra». Note-se a aliteração e a metonimia.

50 Note-se a antítese: armas ... toga. A toga simboliza a paz. Daqui o aforismo da autoria do próprio Cícero cedant arma togae, «que as armas cedam à togay, isto é, que o poder militar se submeta ao civil.

51 Alusão à conjura de Catilina.

52 Árquias começara a escrever um poema sobre o consulado de Cícero, mas não chegou a concluí-lo (vide p. 340).

53 Antes de findar o discurso, Cícero recapitula os principais argumentos a favor do seu constituinte.

54 Vide supra, notas 51 e 52.

55 Era o próprio irmão do Orador, Quinto Túlio Cícero, quem presidia ao julgamento. Além de político e distinto militar, Quinto Cícero possuía uma grande cultura e era dado ao cultivo das letras. 
CATULO (87-54? a.C.)

\section{A sua paixão por Lésbia.}

Ille mi par esse deo uidetur, ille, si fas est, superare diuos, qui sedens aduersus identidem te spectat et audit dulce ridentem, misero quod omnes eripit sensus mihi; nam simul te, Lesbia, aspexi, nihil est super mi uocis in ore, lingua sed torpet, tenuis sub artus

10 flamma demanat, sonitu suopte tintinant aures; gemina teguntur lumina nocte.

Otium, Catulle, tibi molestum est; otio exultas nimiumque gestis.

15 Otium et reges prius et beatas perdidit urbes.

Viuamus, mea Lesbia, atque amemus, rumoresque senum seueriorum omnes unĭus aestimemus assis. Soles occidere et redire possunt; nobis cum semel occidit breuis lux, nox est perpetua una dormienda. $\mathrm{Da}$ mi basia mille, deinde centum, dein mille altera, dein secunda centum, deinde usque altera mille, deinde centum.

10 Dein, cum milia multa fecerimus, * conturbabimus illa, ne sciamus, aut ne quis malus inuidere possit, cum tantum sciat esse basiorum.

* Com a penúltima sílaba longa, como na flexão primitiva. 
A um deus me parece poder-se igualar $e$ - se me é dado um tal pensamentoas divindades mesmo superar, o ser ditoso que, a todo o momento, perante $t i$ sentado, te contempla $e$ te escuta rindo docemente. Ver e ouvir-te do sentir me priva - pobre de mim! -, pois que mal te vi nem uma só palavra, Lésbia, proferi. De língua entorpecida, pelos membros uma chama subtil me vai correndo; co seu próprio tinir os meus ouvidos zunem; de duplas trevas meu olhar se encobre.

O ócio para ti, Catulo, é bem molesto; no ócio te excitas e enervas em excesso. $O$ ócio já antes deitou a perder reis $e$ cidades ricas a valer.

Vivamos, Lésbia minha, para amar e a má-língua desses velhos tão austeros pra nós não valha mais que um simples chavo. Os sóis podem morrer e regressar; mas quando a breve luz da vida se apagar, uma noite infinda teremos de dormir. Dá-me mil beijos, depois mais cem, mais outros mil, mais outros cem ainda, inda outros mil, depois mais cem.

Depois de os termos por milhares contado, havemos de os baralhar, pra não sabermos - nem invejoso algum os possa cobiçarque tantos foram os beijos que trocámos. 
Nulli se dicit mulier mea nubere malle quam mihi, non si se Iupiter ipse petat. Dicit; sed mulier cupido quod dicit amanti in uento et rapida scribere oportet aqua.

(Ibid., 70)

Dicebas quondam solum te nosse Catullum, Lesbia, nec prae me uelle tenere Iouem.

Dilexi tum te non tantum ut uulgus amicam, sed pater ut gnatos diligi et generos.

Nunc te cognoui; quare etsi impensius uror, multo mi tamen es uilior et leuior.

Qui potis est? - inquis. Quod amantem iniuria talis cogit amare magis, sed bene uelle minus.

(Ibid., 72)

Lesbia mi praesente uiro mala plurima dicit;

haec illi fatuo maxima laetitia est. Mule, nihil sentis. Si nostri oblita taceret, sana esset; nunc quod gannit et obloquitur, non solum meminit, sed, quae multo acrior est res, irata est; hoc est, uritur et coquitur.

(Ibid., 83) 
Diz minha amada que a ninguém quer pertencer, senão a mim, nem mesmo a Jove, se ele a requestar. É o que ela diz; mas prò amante, palavras de mulher por força ao vento são lançadas ou ds águas a passar.

Já lá vai tempo em que tu, Lésbia, dizias

que só Catulo teus favores gozava,

e que, por mim, nem mesmo Júpiter querias

em teus braços uma vez só ter enlaçado.

Amei-te, então, com invulgar carinho,

com o amor de pai pelos filhos, pela familia.

Agora, porém, já te conheço,

$e$, embora o meu amor por ti me abrase mais e mais,

tanto mais vil és para mim, mais leviana.

Como pode isso ser? - decerto me perguntas.

É que as traições, que ao meu amor vens a fazer,

a mais amor obrigam, e a menos bem-querer.

Lésbia, na presença do marido, muito mal de mim se farta de dizer; e que contente fica o imbecil!

Grande burro tu és, que nada vês: se ela me esquecesse e se calasse, prova seria da sua indiferença; agora que ela gane e vocifera,

é só porque em mim pensa e, muito mais, porque a raiva, que em sua alma sente, um fogo nela ateia recozente. 
Lesbia mi dicit semper male nec tacet umquam de me; Lesbia me dispeream nisi amat.

Quo signo? quia sunt totidem mea; deprecor illam assidue, uerum dispeream nisi amo.

(Ibid., 92)

Odi et amo. Quare id faciam, fortasse requiris. Nescio, sed fieri sentio et excrucior.

(Ibid., 85)

Nulla potest mulier tantum se dicere amatam uere, quantum a me Lesbia amata mea es.

Nulla fides nullo fuit umquam foedere tanta, quanta in amore tuo ex parte reperta mea est.

(Ibid., 87)

Caeli, Lesbia nostra, Lesbia illa, illa Lesbia, quam Catullus unam plus quam se atque suos amauit omnes, nunc in quadruuiis et angiportis

5 glubit magnanimi Remi nepotes.

(Ibid., 58) 
A dizer mal de mim está sempre Lésbia, sem nunca a meu respeito se calar; eu morra, se Lésbia me não ama.

Querem saber que prova eu tenho disso? É que o meu sentir [o dela iguala: sobre ela são constantes as minhas maldições, mas morra [eu se deixo de amá-la.

Odeio e amo. Como é que isso acontece, perguntas porventura. Não sei, mas sinto que acontece, e um tal viver é uma tortura.

Ter sido tão amada, Lésbia, quanto eu te amei, mulher alguma o pode asseverar. Jamais em ligação alguma a lealdade foi tamanha, como a que no meu amor por ti se pôde achar.

A minha Lésbia, Célio, aquela Lésbia, aquela Lésbia, sim, que eu tanto amei, mais que a mim mesmo e a todos que são meus, agora, por essas encruzilhadas e vielas, do nobre Remo os descendentes ela esfola. 


\section{Convite para jantar}

Cēnābis bene, mi Fabulle, apud mē paucis, si tibi di fauent, diēbus, si tēcum attulĕris ${ }^{1}$ bonam atque magnam cēnam, nōn sine candìdā puellā et uinō et sale et omnibus cachinnis.

Haec si, inquam, attulěris, uenuste noster, cēnābis bene: nam tui Catulli plēnus saccŭlus est araneārum.

Sed contra accipiēs merōs amōrēs seu quid suauius èlegantiusuest 2 : nam unguentum dabō, quod meae puellae dōnārunt ${ }^{3}$ Venĕrēs Cupidinēsque, quod 4 tu cum olfaciēs, deōs rogābis, tōtum ut ${ }^{5}$ te ${ }^{5}$ faciant ${ }^{5}$, Fabulle, nasum.

(Ibid., 13)

\section{Viagem à Bitínia.}

Iam uer egelidos refert tepores, iam caeli furor aequinoctialis iucundis Zephyri silescit auris. Linquantur Phrygii, Catulle, campi Nicaeaeque ager uber aestuosae; ad claras Asiae uolemus urbes. Iam mens praetrepidans auet uagari, iam laeti studio pedes uigescunt. O dulces comitum ualete coetus, longe quos simul a domo profectos diuersae uariae uiae reportant. 
Um bom jantar terás, ó meu Fabulo, em minha casa, queira o céu, dentro de dias,

- se contigo trouxeres as iguarias, e não faltar a bela rapariga e o vinho e o sal e toda a alegria. Se tudo isto trouxeres, ó meu amigo, um bom jantar terás, pois de Catulo a bolsa toda está cheia de aranhas. Em troca receberás amores sinceros e o que de mais grato há, mais requintado: perfume te hei-de dar, que à minha amada as Vénus e os Cupidos ofertaram. Quando o cheirares, aos deuses rogarás que todo te transformem em nariz.

Já suaves dias traz de novo a primavera, já no céu se cala o furor do equinócio ao jucundo sopro das brandas brisas do Zéfiro. As planícies da Frígia, Catulo, deixemos e a fecunda terra da estuosa Niceia: pràs claras cidades da Ásia voemos. Já freme tua alma, por vaguear anseia, já ledos teus pés com o desejo estremecem. $\delta$ doce companha de amigos, adeus! De casa, pra longe, juntamente partimos; pra lá voltaremos por diversos caminhos. 


\section{Junto à sepultura do irmão.}

Multas per gentes et multa per aequora uectus aduenio has miseras, frater, ad inferias, ut te postremo donarem munere mortis et mutam nequiquam alloquerer cinerem, quandoquidem fortuna mihi tete abstulit ipsum, heu miser indigne frater adempte mihi. Nunc tamen interea haec prisco quae more parentum tradita sunt tristi munere ad inferias, accipe fraterno multum manantia fletu, atque in perpetuum, frater, aue atque uale.

(Ibid., 100)

\section{Regresso a casa}

Paene insularum, Sirmio, insularumque ocelle, quascumque in liquentibus stagnis marique uasto fert uterque Neptunus, quam te libenter quamque laetus inuiso, uix mi ipse credens Thuniam atque Bithunos liquisse campos et uidere te in tuto. $\mathrm{O}$ quid solutis est beatius curis, cum mens onus reponit ac peregrino labore fessi uenimus larem ad nostrum desideratoque acquiescimus lecto! Hoc est quod unum est pro laboribus tantis. Salve, o uenusta Sirmio, atque ero gaude; gaudete uosque, o Lydiae lacus undae; ridete, quicquid est domi cachinnorum. 
Por tantos povos, tantos mares levado, eu venho aqui, irmão, para este triste preito, extrema homenagem que à morte se deve, e em vão falar às tuas mudas cinzas, já que a fortuna te separou de mim,

ai! pobre irmão, que no verdor dos anos ao meu afecto arrebatado foste.

Por isso agora, em ancestral costume, eis estas dádıvas, comovida oferta, banhadas todas de fraterno pranto: são para ti, irmão. E, para sempre, o meu sentido, derradeiro adeus.

ö pérola de penínsulas e de insulas, Sírmio, de quantas têm na limpidez dos lagos e na amplidão do mar um e outro Neptuno, com que prazer, com que deleite eu te revejo, mal acreditando ainda que para trás deixei a Tínia e da Bitinia os campos, e sem temor agora te contemplo! Oh que delícia a de não ter cuidados, quando a alma depõe o seu fardo e, fatigados do labor lá fora, ao lar tornamos, a este lar que é nosso, e repousamos no almejado leito! Só este é o prémio por canseiras mil. Salve, $o$ bela Sirmio, e o teu senhor festeja! Festejai-o também, ondas do lago lídio! Ria, na casa, tudo o que riso seja! 
SALÚSTIO (87 ou 86-35 a.C.): UM CONCEITO DE HISTÓRIA

\section{I. - Introdução}

A historiografia foi um dos géneros literários que mais facilmente se implantaram em Roma. De facto, desde cedo começam a aparecer testemunhos evidentes da vocação do Romano para escrever história. Podemos considerar como primeiras manifestações historiográficas, não só as velhas listas de magistrados, que periodicamente se publicavam, mas também os antiquíssimos Anais dos Pontífices. Não obstante a sua singeleza, apesar da sua secura e aridez de estilo, estes documentos constituem os pródromos da historiografia romana.

Considerada propriamente como género literário, a historiografia tem o seu início em Catão, o Censor ${ }^{1}$, político famoso e autor de uma obra sobre antiguidades romanas, intitulada Origines. Mas a narrativa de Catão é ainda do tipo muito rudimentar. O que principalmente lhe interessa são listas de factos; falta ainda nele aquilo a que chamamos concepção crítica da história. Para que esta concepção surja e se desenvolva, torna-se necessário que os historiadores romanos recebam a influência directa dos historiadores gregos.

Mas em que historiadores gregos devemos atentar?

A historiografia grega apresenta como primeiros ensaios os escritos dos chamados logógrafos, autores de narrativas, na sua maior parte lendárias. Estes, claro está, não contam para o nosso caso. Depois dos logógrafos, vem Heródoto que já pode ser considerado como verdadeiro historiador. Contudo, o seu método é ainda muito deficiente, pois ocorrem na sua obra grande número de lendas, a pretexto de reproduzir tudo quanto ouviu nas suas viagens. Além disso, peca por excessiva credulidade e tem a ingenuidade de colocar os acontecimentos sob a guarda dos deuses. Não é, portanto, a Heródoto que devemos ligar os grandes historiadores romanos, aqueles que melhor representam o género e nos quais se desenvolve melhor a concepção crítica: César, Salústio, Tito Lívio e Tácito.

Os grandes mestres dos historiadores romanos foram Tucídides e Xenofonte, sobretudo o primeiro.

Tucídides é o autor da História da Guerra do Peloponeso. Beneficia esta obra da circunstância do seu autor ter sido espectador de grande parte dos acontecimentos narrados. É inegável, porém, que

1 Vd. p. 360 , nota 6. 
possui mais talento de narrador e mais génio de escritor, que qualquer outro historiador grego. Para Tucídides, os aspectos psicológicos não valem mais do que os factos materiais e, para fazer compreender os acontecimentos, as suas causas, o seu encadeamento, as suas consequências, abstém-se de penetrar os desígnios dos deuses; além disso, manifesta em toda a sua obra uma preocupação constante de verdade. A concepção da história de Tucídides pode resumir-se nestas palavras, que ele próprio escreveu: $\varkappa \tau \tilde{\eta} \mu \alpha \dot{\varepsilon}^{\prime} \varsigma \dot{\alpha} \varepsilon \dot{\varepsilon}$, isto é, utilidade para sempre: em vez de uma história episódica, efémera, Tucídides visa escrever uma história que seja uma utilidade permanente, ao mesmo tempo um exemplo e uma lição. Está nisto o seu lema que tanto há-de impressionar e será fonte de inspiração para escritores futuros. Ora, de Tucídides dependem alguns historiadores romanos, como é, por exemplo, Tácito e como é também o autor de quem nos vamos especialmente ocupar, Salústio.

Sob este aspecto ficam de fora Júlio César e Tito Lívio. César, no cultivo da prosa histórica como na vida pública, é, ou procura ser, um romano de lei, justamente penetrado do espírito nacional; por sua vez, Tito Lívio, embora não deixe de receber influência grega, recebe-a mais propriamente nas fontes do que na concepção histórica. É que para Tito Lívio a história tem mais um interesse geral e patriótico do que um interesse particular ou político. Para Tito Lívio, a história é menos um fim do que um meio. É um meio de erguer um monumento imorredoiro à glória do povo romano, o qual considera o primeiro do mundo: princeps terrarum. E não há dúvida que o $A b$ urbe condita ficou como uma espécie de epopeia em prosa da época de Augusto, podendo bem dizer-se que está para a Eneida de Virgílio, como a Ásia de Barros está para Os Lusiadas.

Em Salústio, diversamente, o que encontramos é a história política. Nisto é ele, justamente, um discípulo directo de Tucídides, e a lição do historiador grego está ainda patente noutros aspectos: na preocupação da verdade, no gosto de relacionar os acontecimentos, na análise psicológica fortemente dominada pela ideia, muito vigorosamente expressa nos Prefácios de Salústio, de que o espírito humano impera sobre a matéria que o rodeia (vide pp. 379-383).

Chegaram até nós deste historiador duas obras muito importantes: Conjuração de Catilina (De coniuratione Catilinae) e Guerra de Jugurta (De bello Iugurthino). Mas também nos ficaram alguns restos de outra obra não menos importante: Histórias (Historiarum libri quinque). 
Na Conjuração de Catilina, descreve-se a célebre conspiração que teve como principal figura Lúcio Sérgio Catilina e que tanto agitou a vida romana nos últimos tempos da República. Na Guerra de Jugurta, descrevem-se as lutas dos Romanos contra Jugurta, o célebre rei da Numídia. Nas Histórias, de que só nos restam, além de alguns fragmentos muito truncados, duas cartas e quatro discursos que nelas figuravam, descreviam-se os acontecimentos ocorridos em Roma entre o ano 78 e o ano 67, durante um período de especial importância na vida da República com o renascimento do partido democrático.

Os fragmentos que nos restam das Histórias não chegariam para avaliar Salústio, mas as outras duas obras são bastantes para julgar da sua personalidade de escritor e do seu talento de historiador.

\section{II. - Salústio historiador}

A orientação de Salústio está claramente expressa nos Prefácios das suas duas obras mais importantes. Cumpre-nos, porém, fixar neste ponto dois aspectos especiais:

a) Foi Salústio tão exacto e imparcial como apregoou?

A resposta é negativa, porque nas suas obras, nomeadamente na Conjuração de Catilina, há exemplos evidentes de parcialidade. Um deles está na maneira como apagou, de certo modo intencionalmente, a figura de Cícero, apesar de lhe chamar optimus consul. Além disso, esta obra parece obedecer a um intuito reservado: ilibar a memória de Júlio César de toda a suspeita de cumplicidade na conjura.

b) Foi Salústio tão observante da moral e dos principios morais que devem reger a vida das sociedades, como poderemos deduzir das suas obras?

Neste ponto cava-se um profundo abismo entre o Salústio historiador e o Salústio homem-cidadão. É que não nos devemos esquecer que ele foi o epicurista que mandou construir para seu gozo pessoal um palácio, em Roma, no monte Quirinal, onde abundavam as riquezas - algumas delas ilicitamente adquiridas! - e onde se dava à prática dos 
mais requintados mundanismos; e que foi também o procônsul suspeito de prevaricações várias, não se tendo livrado, pelo menos uma vez, da acusação do crime de concussão.

Alguns historiadores da literatura latina, e em especial alguns salustianistas, têm procurado reabilitar Salústio sob o aspecto moral. Mas claro está que o têm feito em vão. O mais que se poderá, é justificar a corrupção dos costumes em Salústio pela corrupção da própria época em que viveu. A posteridade teria sido mais indulgente para com ele se não fosse o ter-se arvorado, nos Prefácios das suas obras, em censor implacável dos vícios em que, afinal, ele próprio incorria.

\section{III. - Salústio escritor}

Antes de mais, importa notar que Salústio é mestre em certos processos artísticos de que muito habilmente se aproveita. Dois deles, e precisamente dos mais notáveis, estão nos retratos e nos discursos, os quais muito contribuem para dar variedade e animação à narrativa. Entre os retratos, os exemplos mais expressivos são, porventura, o de Catilina (cap. V), o de Semprónia (cap. XXV) e os de César e Catão (cap. LIV), todos da Conjuração de Catilina. No caso particular dos retratos de César e Catão, seria difícil obter maior vigor e maior nitidez do que Salústio neles conseguiu, ao pintar as efígies desses dois romanos por meio de contrastes extraordinariamente impressivos.

Mas os discursos não são menos dignos de atenção. Claro que eles não constituem propriamente as peças oratórias proferidas, em determinadas circunstâncias, pelas personagens às quais Salústio os atribui. Nestes casos, Salústio, como tantos historiadores que o precederam e se lhe seguiram, faz modificações, com naturais empregos literários, ao pôr na boca dos seus oradores as palavras que julga terem sido ditas nas circunstâncias respectivas. E deste modo, também, o historiador cedeu o lugar ao escritor. E cedeu-o, evidentemente, com grande elevação de estilo, porque os discursos salustianos são elementos notáveis de colorido, que muito valorizam a sequência da narrativa histórica. Diga-se de passagem, que os discursos representam um processo já adoptado pelos historiadores gregos, que directamente o 
receberam dos Poemas Homéricos ${ }^{1}$, que por si mesmos o tinham recebido da própria vida grega.

Notem-se ainda algumas características especiais do estilo de Salústio:

a) CONCIS̃̃o (breuitas): emprego de frases curtas, sobretudo com a utilização de processos braquilógicos ou elípticos.

b) VAREDADE (uarietas): emprego de vários processos, nomeadamente dois que são muito típicos em Salústio: as antíteses e a dissimetria (inconcinnitas). Quer nas antíteses quer na dissimetria, Salústio quer seguir o exemplo de Tucídides. É de notar que, no emprego deste último processo, o estilo de Salústio se distingue do de Cícero, que tem como característica comum a simetria (concinnitas).

c) Emprego frequente de metáforas que só por si dão ao estilo salustiano uma certa cor poética (color poeticus).

d) Ausência de cláusulas métricas adoptadas por Cícero e pela escola ciceroniana.

e) Emprego frequente de arcaísmos. Neste aspecto, também Salústio parece querer imitar Tucídides. Com o emprego de palavras e construções arcaicas o Historiador procura dar à prosa histórica uma cor grave e severa.

Quanto aos arcaísmos importa lembrar que a sua frequência em Salústio feriu já a atenção dos antigos. O Historiador foi até acusado de rebuscar palavras obsoletas nas velhas obras de Catão. Devemos notar, contudo, que nem todos os arcaísmos salustianos, geralmente apontados pelos comentadores, são verdadeiramente arcaísmos. Alguns há que o são apenas na aparência ou não o são na medida em que geralmente se supõe. Estão neste caso, além do acusativo do plural em -is (p. ex. omnis =omnes) e dos superlativos em -umus, as grafias como nouos (= nom. nouus), uolt $(=$ uult $)$, aequom $(=$ aequum), uolnus $(=$ uulnus $)$, etc. Neste caso, estamos em presença de um expediente gráfico para evitar, na escrita, a sequência VV (=uu).

1 Vd. p. 344. 


\section{SALLVSTI CRISPI}

DE CONIVRATIONE CATILINAE

I. Omnis homines qui sese student praestare ceteris animalibus summa ope niti decet ne uitam silentio transeant ueluti pecora, quae natura prona atque uentri oboedientia finxit. Sed nostra omnis uis in animo et corpore sita est; animi imperio, corporis seruitio magis utimur; alterum nobis cum dis, alterum cum beluis commune est. Quo mihi rectius uidetur ingenii quam uirium opibus gloriam quaerere et, quoniam uita ipsa qua fruimur breuis est, memoriam nostri quam maxume longam efficere. Nam diuitiarum et formae gloria fluxa atque fragilis est, uirtus clara aeternaque habetur.

Sed diu magnum inter mortalis certamen fuit uine corporis an uitute animi res militaris magis procederet. Nam et prius quam

I. Todos os homens, que procuram distinguir-se dos outros animais, devem esforçar-se por todos os meios para não levar a vida obscuramente, como as alimárias, que a natureza curvou e fez escravas de apetites. Ora, toda a nossa força reside na alma e no corpo: pela alma somos mais senhores, pelo corpo, mais escravos; aquela nos equipara aos deuses, este aos animais. É, por isso, mais justo, parece-me, buscar a gloria pelas faculdades espirituais do que pelas forças físicas e, já que é efémera a vida de que fruimos, [igualmente me parece justo] fazer tão longa quanto possível a memória de nós mesmos. É que das riquezas e da beleza só advém glória fugidia e frágil, a virtude é uma posse brilhante e duradoura.

Não obstante, houve já por longo tempo grande pleito entre os mortais: se uma empresa militar lucraria mais com a força física, se com o vigor espiritual. A verdade é que, antes de se começar, importa 
incipias consulto et, ubi consulueris, mature facto opus est. Ita utrumque per se indigens alterun alterius auxilio eget.

II. Igitur initio reges (nam in terris nomen imperii id primum fuit) diuorsi, pars ingenium, alii corpus exercebant; etiam tum uita hominum sine cupiditate agitabatur, sua cuique satis placebant. Postea uero quam in Asia Cyrus, in Graecia Lacedaemonii et Athenienses coepere urbis atque nationes subigere, lubidinem dominandi causam belli habere, maxumam gloriam in maxumo imperio putare, tum demum periculo atque negotiis compertum est in bello plurumum ingenium posse. Quodsi regum atque imperatorum animi uirtus in pace ita ut in bello ualeret, aequabilius atque constantius sese res humanae haberent, neque aliud alio ferri, neque mutari ac misceri omnia cerneres. Nam imperium facile eis artibus retinetur, quibus initio partum est. Verum ubi pro labore desidia, pro continentia et aequi-

deliberar, e, uma vez tomada a deliberação, convém actuar prontamente. Quer dizer: uma e outra forças, insuficientes por si, não dispensam o auxilio mútuo.

II. Ora, ao princípio os reis - pois foi esse no mundo o primeiro nome da soberania - diversos [em suas tendências], parte deles exercitava o espirito, outros o corpo; também então a vida humana decorria sem ambição e cada qual se contentava com a sua sorte. Mas quando Ciro na Ásia e na Grécia Lacedemónios e Atenienses começaram a submeter cidades e povos, a ter por motivo de guerra a paixão do mando, a ver a maior glória no maior poder, foi então que a experiência e as empresas vieram mostrar quanto pode na guerra valer o espirito. Ora, se a força de ânimo de reis e governantes valesse na paz o mesmo que na guerra, mais regular e firme seria o curso das ações humanas, e não se veriam reviravoltas nem esta mutação e confusão geral. É que facilmente se conserva o mando com o mesmo procedimento que the deu origem. Mas quando o trabalho cedeu à inércia, e a moderação e a 
tate lubido atque superbia inuasere, fortuna simul cum moribus immutatur. Ita imperium semper ad optumum quemque a minus bono transfertur. Quae homines arant, nauigant, aedificant, uirtuti omnia parent. Sed multi mortales, dediti uentri atque somno, indocti incultique, uitam sicuti peregrinantes transiere; quibus profecto contra naturam corpus uoluptati, anima oneri fuit. Eorum ego uitam mortemque iuxta aestumo, quoniam de utraque siletur. Verum enimuero is demum mihi uiuere atque frui anima uidetur, qui aliquo negotio intentus praeclari facinoris aut artis bonae famam quaerit. Sed in magna copia rerum aliud alii natura iter ostendit.

III. Pulchrum est bene facere rei publicae, etiam bene dicere haud absurdum est; uel pace, uel bello clarum fieri licet; et qui fecere, et qui facta aliorum scripsere, multi laudantur. Ac mihi quidem,

equidade cederam à paixão e à soberba, logo mudam juntamente fortuna e costumes. Assim, o poder, por via de regra, passa dos menos bons para os melhores. Seja o que for que os homens lavrem, naveguem, edifiquem, tudo obedece à virtude. Muitos homens, porém, somente dados ao comer e ao dormir, indoutos e incultos, passaram a vida como peregrinos: para esses, decerto, contrariamente à natureza, o corpo foi prazer, o espirito [simples] fardo. Vida e morte deles tenho-as na mesma conta, pois sobre ambas se faz silêncio. Pelo contrário, creio realmente que só vive e tira proveito do seu espirito aquele que se vota a uma actividade e busca a fama de uma ação ilustre ou de uma arte digna. Mas na grande profusão das coisas humanas, a natureza mostra a cada qual o seu caminho.

III. É uma bela coisa fazer bem à república, mas dizer bem dela também não é inoportuno: tanto pode dar lustre a paz como a guerra; não só autores de feitos como ainda narradores, muitos são os que recebem louvores. Quanto a mim, sejam embora de todo em todo desiguais 
tametsi haud quaquam par gloria sequitur scriptorem et auctorem rerum, tamen in primis arduum uidetur res gestas scribere: primum, quod facta dictis exaequanda sunt; dehinc, quia plerique, quae delicta reprehenderis, maliuolentia et inuidia dicta putant; ubi de magna uirtute atque gloria bonorum memores, quae sibi quisque facilia factu putat, aequo animo accipit, supra ea ueluti ficta pro falsis ducit. Sed ego adulescentulus initio, sicuti plerique, studio ad rem publicam latus sum, ibique mihi multa aduorsa fuere. Nam pro pudore, pro abstinentia, pro uirtute, audacia, largitio, auaritia uigebant. Quae tametsi animus aspernabatur, insolens malarum artium, tamen inter tanta uitia imbecilla aetas, ambitione corrupta, tenebatur; ac me, cum ab reliquorum malis moribus dissentirem, nihilo minus honoris cupido eadem quae ceteros fama atque inuidia uexabat.

a glória de um escritor e a de um heroi, contudo parece-me empresa sobremodo árdua escrever a história: primeiramente, porque é necessário emparelhar acções e linguagem, depois, porque a maioria dos leitores leva à conta de malquerença e de inveja as faltas que porventura se hajam criticado; e, ao celebrar-se a grande virtude e a glória dos bons cidadãos, qualquer aceita, sem se perturbar, o que julga fácil para si mesmo, mas aquilo que ultrapassa tal medida, considera-o falso, como se fora inventado. Ora, quanto a mim, era ainda muito jovem, fui a princípio, como tantos, levado por paixão à vida pública, e não me faltaram aí contrariedades. De facto, em vez da moderação, do desinteresse, da virtude, medravam a audácia, a corrup̧̧ão, a cobiça. Se bem que a minha alma, não afeita a práticas ruins, as repelisse com desdém, todavia a fraqueza da idade, corrompida pela ambição, ficava presa entre tamanhos vícios; $e$, apesar de eu reprovar os maus costumes dos outros, o certo é que o desejo de honras me atormentava, como aos demais, pela maledicência e pela inveja. 
IV. Igitur, ubi animus ex multis miseriis atque periculis requieuit et mihi reliquam aetatem a re publica procul habendam decreui, non fuit consilium socordia atque desidia bonum otium conterere, neque uero agrum colundo aut uenando, seruilibus officiis, intentum aetatem agere; sed a quo incepto studioque me ambitio mala detinuerat, eodem regressus statui res gestas populi Romani carptim, ut quaeque memoria digna uidebantur, perscribere, eo magis quod mihi a spe, metu, partibus rei publicae animus liber erat. Igitur de Catilinae coniuratione quam uerissume potero paucis absoluam; nam id facinus in primis ego memorabile existumo sceleris atque periculi nouitate. De cuius hominis moribus pauca prius explananda sunt quam initium narrandi faciam.

IV. Ora, assim que o meu espirito descansou de tantas penas $e$ trabalhos, e que me impus levar o resto da existência longe da politica, não resolvi consumir o belo ócio na apatia e na indolência, nem tão pouco tencionei passar a vida no amanho de uma terra ou na caça, ocupações servis; diversamente, voltando ao desígnio e à inclinação de que me arredara a ambição funesta, decidi escrever, em monografias completas, a história do povo romano, à proporção da lembrança que, em meu entender, cada um dos factos merecia, tanto mais que a minha alma estava, enfim, liberta de anseios, de temores, de partidarismos politicos. Vou, por isso, fazer sumariamente, e tanto fiel quanto possivel, o relato integral da conjuração de Catilina, facto que considero particularmente memorável pela novidade do crime e do perigo nacional. Cumpre-me dizer alguma coisa sobre o carácter do homem, antes de dar começo à narrativa. 


\section{HORÁCIO (65-8 a.C.): TRÊS TEMAS DE CULTURA}

\section{I - A linguagem}

In uerbis etiam tenuis cautusque serendis dixeris egregie, notum si callida uerbum reddiderit iunctura nouum. Si forte necesse est indiciis monstrare recentibus abdita rerum, et fingere cinctutis non exaudita Cethegis continget dabiturque licentia sumpta pudenter, et noua fictaque nuper habebunt uerba fidem, si Graeco fonte cadent parce detorta. Quid autem Caecilio Plautoque dabit Romanus, ademptum Vergilio Varioque? Ego cur, adquirere pauca si possum, inuideor, cum lingua Catonis et Enni sermonem patrium ditauerit et noua rerum nomina protulerit? Licuit semperque licebit

Sendo, além disso, delicados e prudentes no arranjo das palavras, exprimir-nos-emos com perfeição: uma ligação subtil poderá dar novidade a um vocábulo corrente. Se, porventura, precisarmos de exprimir com sinais novos ideias desconhecidas e de forjar palavras não ouvidas dos Cetegos que usavam cinto, teremos licença de fazê-lo, contanto que o façamos comedidamente; e as palavras novas e forjadas de pouco serão bem aceites, se forem importadas com discrição e derivadas da fonte grega. Que há-de o Romano dar a Cecílio e a Plouto, e tirar a Virgílio e a Vário? Porque é que me invejam, sendo eu capaz de granjear umas quantas palavras, quando a linguagem de Catão e de Énio enriqueceu o idioma pátrio e deu nomes novos às ideias? Foi e sempre 
signatum praesente nota producere nomen.

Vt siluae foliis pronos mutantur in annos,

prima cadunt, ita uerborum uetus interit aetas,

et iuuenum ritu florent modo nata uigentque.

Debemur morti nos nostraque. Siue receptus

terra Neptunus classes Aquilonibus arcet,

regis opus, sterilisue diu palus aptaque remis

uicinas urbes alit et graue sentit aratrum,

seu cursum mutauit iniquum frugibus amnis,

doctus iter melius, mortalia facta peribunt,

nedum sermonum stet honos et gratia uiuax.

Multa renascentur quae iam cecidere, cadentque

quae nunc sunt in honore uocabula, si uolet usus,

quem penes arbitrium est et ius et norma loquendi.

(De arte poetica, 46-72)

será lícito criar uma designação de cunho actual. Assim como os bosques mudam de folhas no decurso de cada ano, e são as primeiras que vão caindo, assim se extingue a geração antiga dos vocábulos, e, quais outros jovens, florescem e vicejam os há pouco nascidos.

Estamos sujeitos à morte, nós e tudo quanto é nosso. Pode Neptuno acolher-se à terra e furtar as armadas aos Aquilões, obra própria de rei; pode a lagoa, por largo tempo estéril e só afeita aos remos, sustentar as cidades vizinhas e sentir o peso do arado; pode o rio ter mudado o seu curso, nefasto às sementeiras, por haver aprendido melhor caminho; não importa: as obras humanas acabarão, e muito menos hão-de perdurar o lustro e a autoridade das palavras. Renascerão inúmeros termos que já morreram e morrerão os que andam actualmente em voga, se assim o quiser o uso que só por si formula, determina e regula as leis da linguagem. 


\section{Ideias fundamentais}

Horácio entende que a linguagem não pode ser descurada, para poder estar eficientemente à disposição da criação literária. Nas línguas, como na vida humana, como na própria vida das plantas, a inovação é uma necessidade permanente, sem a satisfação da qual não poderia haver desenvolvimento progressivo.

É certo que o talento de um artista pode dar efeitos novos às palavras correntes, saberá até rejuvenescê-las pelo simples emprego de ligações mais ou menos engenhosas. Mas é evidente que este processo, por muito habilmente que seja utilizado, não bastará para revitalizar o idioma. Circunscrever a expressão linguística apenas à herança do passado seria deplorável estreiteza de vistas e inevitável estagnação e decomposição da linguagem. É, portanto, indispensável reviver a linguagem sob pena de ela não ser caracteristicamente viva e verdadeiramente actual; e para a renovar não basta apenas criar palavras, é preciso saber criá-las com o puro sentido de actualidade. Força é, também, reconhecer e aceitar os destinos por vezes contraditórios que o uso dá aos vocábulos já existentes, visto que um morre, apesar de ter voga, e outros há que renascem, apesar de extintos.

\section{Ideias acessórias}

(i) Admitindo a criação de palavras, Horácio diz-nos também o que pensa sobre as condições e processos dessa criação. Em resumo, entende o seguinte:

a) que é lícito fazer corresponder a uma ideia nova, palavras novas;

b) que é recomendável a importação de vocábulos ao grego, atendendo à sua tradição;

c) que, todavia, a criação de palavras deve ser feita moderadamente. 
Mas não se suponha que, relativamente às importações ao grego, Horácio pensa em palavras mais ou menos literalmente reproduzidas da língua helénica (como, p. ex., musica, philosophia, rhetorica, etc.): as importações deste género não tinham a fama do uso antigo e o seu número era, até então, relativamente limitado. No que Horácio pensa é em palavras decalcadas em vocábulos gregos, quer por meio de correspondência de elementos, quer pela simples correspondência de sentido. E que assim é, sabêmo-lo, não apenas por uma informação de Quintiliano (VIII, 3, 33), mas também, ao que parece, pela palavra ficta 'forjadas' do v. 52 .

(ii) As alusões de Horácio a Virgílio, a Vário e a si próprio deixam ver que ele tomava "partido» pelos Modernos, sem tão-pouco desdenhar dos Antigos. A ênfase com que reconhece aos escritores contemporâneos o mesmo direito de criar palavras a que se tinham permitido Plauto, Catão, Énio, Cecílio, mostra bem o seu pendor para a defesa dos Modernos, defesa que ele abertamente faz na Epístola I do livro II, dirigida a Augusto, e que desenvolve com argumentos particularmente subtis, como este:

Quod si tam Graecis nouitas inuisa fuisset quam nobis, quid nunc esset uetus?...

(vv. 90-91)

«Ora se os Gregos houvessem detestado a novidade tanto como nós, que haveria agora de antigo?...»

\section{Alguns pormenores}

(i) A referência aos 'sinais novos' (indiciis ... recentibus: v. 49) com que hão-de exprimir-se os conceitos novos, as ideias ainda não expressas, denuncia leituras filosóficas que, na verdade, não faltam nunca ao Poeta; mas faz-nos também pensar numa confissão de Lucrécio no De rerum natura, I, vv. 136-139, a respeito dos conceitos filosóficos que era forçoso reproduzir por meio de neologismos, embora as dificuldades fossem inúmeras, dada a reconhecida desproporção entre a riqueza do pensamento grego e a pobreza ancestral da língua latina. 
(ii) Porquê, a referência a Vário ao lado de Virgílio?

Lúcio Vário não merece ser citado propriamente por ser um escritor de primeira grandeza, mas sim porque é um letrado de grande prestígio na época de Augusto e figura proeminente da mesma roda literária a que Horácio pertencia.

Houve, de facto, nessa época vários círculos literários importantes, como o de Mecenas, o de Asínio Polião e o de Marco Valério Messala.

Vário esteve mais ou menos ligado ao círculo de Mecenas, juntamente com Horácio, Virgílio, Quintílio Varo, Propércio, etc., e nele tomou parte em discussões sobre os problemas de literatura, que muito interessavam aos espíritos de então.

(iii) A comparação das palavras com a folhagem dos bosques não é inteiramente original. Já na poesia grega se encontram conceitos semelhantes, como é o caso daqueles versos da Ilíada VI, vv. 146-149, em que Homero compara o destino dos mortais com o destino das folhas, por um e outro serem efémeros:

«Tal como a geração das folhas, assim é também a dos homens. As folhas, umas deita-as o vento ao chão, e logo a floresta viçosa cria outras, quando surge a primavera. Assim nasce uma raça de homens, e outra cessa de existir.»

(Trad. de M. H. da Rocha Pereira, Hélade. Coimbra, 41982, p. 24)

No entanto, a composição horaciana possui tal colorido e viveza que pôde ficar na tradição literária e tornar-se quase proverbial. Vários são os imitadores nas literaturas modernas, podendo citar-se, por exemplo, um passo da Sátira II de Correia Garção:

Ao tempo estão sujeitas as palavras;

umas se fazem velhas, outras nascem:

assim vemos a fértil primavera

encher de folhas ao robusto tronco,

a quem despiu o inverno desabrido.

Mudam-se os tempos, mudam-se os costumes. 


\section{II - A epopeia}

Nec sic incipies, ut scriptor cyclicus olim:

«Fortunam Priami cantabo et nobile bellum».

Quid dignum tanto feret hic promissor hiatu?

Parturient montes, nascetur ridiculus mus.

Quanto rectius hic, qui nil molitur inepte:

«Dic mihi, Musa, uirum, captae post tempora Troiae

qui mores hominum multorum uidit et urbes».

Non fumum ex fulgore, sed ex fumo dare lucem

cogitat, ut speciosa dehinc miracula promat,

Antiphaten Scyllamque et cum Cyclope Charybdim.

$\mathrm{Nec}$ reditum Diomedis ab interitu Meleagri, nec gemino bellum Troianum orditur ab ouo; semper ad euentum festinat et in medias res non secus ac notas auditorem rapit, et quae desperat tractata nitescere posse relinquit, atque ita mentitur, sic ueris falsa remiscet, primo ne medium, medio ne discrepet imum.

(ibid., vv. 136-152)

E não irás começar assim, como outrora um poeta cíclico: «Eu cantarei a fortuna de Príamo e a guerra famosa». Que obra digna de tal abertura deitará o autor desta promessa? Os montes darão à luz, nascerá ridículo ratinho. Quanto mais a preceito não começará este, que nada faz a despropósito: "Musa, fala-me do varão, que depois da época da tomada de Tróia, viu costumes e cidades de tantos homens». Não visa tirar fumo de um clarão, mas de simples fumo tirar luz, para dai fazer sair brilhantes prodigios: Antifates e Cila e Caribdis e o Ciclope. E não principia a volta de Diomedes pela morte de Melagro, nem a guerra troiana pelos dois ovos; sempre se dá pressa no desenlace; leva o ouvinte para o meio da acção, como se ela fora conhecida; deixa de lado as matérias que não tem esperança de que possam brilhar; è são tais as suas fiç̧ões, tal a sua mistura de fábulas com verdades, que nem o princípio destoa do meio, nem o meio destoa do fim. 
COMENTÁRIO LITERÁRIO

\section{Ideias fundamentais}

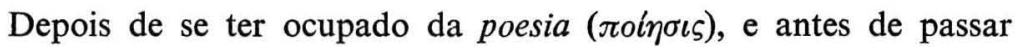
ao poeta ( $\pi \circ \imath \tau \eta \dot{\zeta} s)$, nos vv. 304 sqq., Horácio inicia neste passo a parte

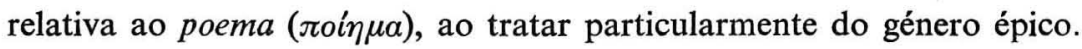

São duas as ideias fundamentais:

a) a matéria de uma epopeia deve ser apresentada com sobriedade;

b) essa matéria deve ser narrada por forma viva e harmoniosa.

Quanto à sobriedade na apresentação da matéria, ressalta bem o seu valor do contraste entre a Proposição de um poema cíclico, cujo nome Horácio não diz, e a Proposição da Odisseia que ele resume em dois versos. Além, um prelúdio enfático, ambicioso, que não condizia com a mediocridade do assunto; aqui, um intróito simples, sóbrio, em que a matéria do poema é colocada sob os auspícios da Musa, passando modestamente a segundo plano a figura do poeta.

O mérito desta última Proposição está em ser, evidentemente, o ponto de partida para um desenvolvimento natural e brilhante, um fumo que há-de mudar-se em luz, em vez de um clarão que há-de converter-se em fumo.

Quanto às características da narrativa, é preciso, antes de mais, que ela seja bem viva, e, por isso, convém dispensar os longos preâmbulos e todas as superfluidades: que o poeta vá direito ao centro da acção, como se esta já fosse conhecida do leitor - ou melhor, do ouvinte - , sem contudo se esquecer de que o poema se deve distinguir pela harmonia e homogeneidade das suas partes, graças a uma hábil mistura da realidade com a ficção.

É de notar que o preceito contido nas palavras in medias res... auditorem rapit ficou a constituir norma fundamental da epopeia clássica, cuja observância está bem patente em Virgílio, e que, por influên- 
cia da lição virgiliana, é classicamente seguida em Os Lusíadas. De facto, assim como a descrição da viagem de Eneias não começa propriamente em Tróia, mas já muito perto da Península Itálica, quando a frota troiana perdia de vista as costas da Sicília (c. I, vv. 34 sqq.) em direcção à terra que lhe fora prometida, assim também a narração da viagem do Gama não tem início na Praia do Restelo, mas já quando

\author{
cortava o mar a gente belicosa \\ já lá da banda do Austro e do Oriente, \\ entre a costa Etiópica e a famosa \\ ilha de São Lourenço...»
}

(c. I, est. 42 , vv. 3-6)

\title{
2. Ideias acessórias
}

Neste passo horaciano está implícita uma ideia acessória que completa a principal. Resume-se ela no seguinte: para Horácio o grande poeta épico é Homero, e os grandes modelos de poemas épicos são precisamente os Poemas Homéricos. Não há poeta cíclico que possa comparar-se ao autor da Ilíada e Odisseia, e não há poema cíclico que se compare a estes dois. Este conceito pode parecer supérfluo, atendendo ao prestígio tradicional e indiscutível de Homero, e levando em conta também os méritos precários e muito discutíveis daqueles poetas que se propuseram alongar e completar as matérias da Ilíada e da Odisseia, ora narrando os acontecimentos que precederam a cólera de Aquiles, esta cantada por Homero no início da Ilíada, ora descrevendo a destruição de Tróia e os regressos dos diversos

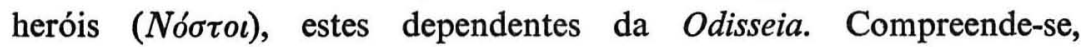
porém, que Horácio não deixa de inculcar aos seus leitores o primado da arte homérica, porque o seu intuito é recomendar, ou pelo menos sugerir, o valor dos grandes padrões do classicismo e orientar neste sentido o gosto literário. Demais, havia então, neste campo, não apenas espíritos hesitantes, como ainda prenúncios de reaç̧ão anticlássica que importava combater e evitar. 


\section{Alguns pormenores}

(i) O verso 139 baseia-se numa fábula que passou da literatura grega para a latina, e desta para as literaturas modernas. Tamanha foi a sua vulgarização, que já entre os Gregos ela se condensara num provérbio, sendo nesse tom proverbial que Horácio diz: parturient montes, nascetur ridiculus mus. Será neste mesmo tom proverbial que Boileau (L'Art Poétique, III, vv. 269-274) dirá mais tarde:

Que le début soit simple et n'ait rien d'affecté.

N'allez pas dès l'abord, sur Pégase monté,

crier à vos lecteurs, d'une voix de tonnerre:

«Je chante le vainqueur des vainqueurs de la terre.»

Que produira l'auteur après tous ces grands cris?

La montagne en travail enfante une souris. ${ }^{1}$

(ii) Antífates, Cila, Caríbdis e Polifemo constituem exemplos de ficções que Homero engenhosamente incrusta na matéria épica da Odisseia (vejam-se cc. IX, X e XII), sendo por isso que Horácio lhes faz referência.

(iii) Quando Horácio diz gemino ...ab ouo, faz alusão aos dois ovos de Leda, de um dos quais tinham nascido Clitemnestra e Helena, esta a causadora da Guerra de Tróia. 2

Nesta alusão subentende-se, naturalmente, um elogio da Ilíada, visto que este poema, em vez de começar a narrativa pela descrição absurda da ascendência mitológica de Helena, transporta imediatamente o ouvinte para o cenário bélico dos últimos meses da Guerra de Tróia.

1 Que o começo seja simples e sem nada de afectado.

Não vás desde logo, sobre Pégaso montado, clamar aos leitores, co'um tom tremebundo: «Eu canto o vencedor dos vencedores do mundo.» Que produzirá o autor após um tal espalhafato? A montanha a parir dará à luz um rato.

2 Vd, a história de Júpiter e Leda, na p. 145, e cap. V da p. 173. 


\section{III - $O$ teatro}

Ignotum tragicae genus inuenisse Camenae

dicitur et plaustris uexisse poemata Thespis

quae canerent agerentque peruncti faecibus ora.

Post hunc personae pallaeque repertor honestae

Aeschylus et modicis instrauit pulpita tignis

et docuit magnumque loqui nitique coturno.

Successit uetus his comoedia, non sine multa laude; sed in uitium libertas excidit et uim dignam lege regi; lex est accepta chorusque turpiter obticuit sublato iure nocendi.

Nil intemptatum nostri liquere poetae, 285 nec minimum meruere decus uestigia Graeca ausi deserere et celebrare domestica facta, uel qui praetextas uel qui docuere togatas.

Dizem que Téspis inventou o género desconhecido da Camena trágica e transportou, em carros, os poemas dramáticos, para que os actores os cantassem e representassem com o rosto besuntado de borras de vinho.

Depois dele, Ésquilo, inventor da máscara e do manto solene, estendeu tablados sobre simples barrotes e ensinou a falar em voz sonora e a firmar-se no conturno.

Sucedeu a estes a comédia antiga não sem grandes aplausos; mas a liberdade descambou em vicio e em violência, merecedora do travão da lei: aceitou-se a lei, e o coro passou pela vergonha de se calar, uma vez sem direito de fazer mal.

Os nossos poetas nada deixaram por tentar e não mereceram menor honra por ousarem afastar-se das pisadas gregas e celebrar os feitos nacionais, quer fizessem representar fábulas pretextas, quer togadas. 
$\mathrm{Nec}$ uirtute foret clarisue potentius armis quam lingua Latium, si non offenderet unum quemque poetarum limae labor et mora. Vos, o Pompilius sanguis, carmen reprehendite quod non multa dies et multa litura coercuit atque praesectum deciens non castigauit ad unguem.

(ibid., vv. 275-294)

O Lácio não seria mais poderoso pela virtude e pelas armas ilustres do que pelo idioma, se o labor da lima e o vagar necessário não fossem penosos a cada poeta. Vos, ó sangue de Pompílio, censurai o poema que não sofreu emendas de muitos dias e rasuras sem conta, que não foi muitas vezes castigado e brunido.

COMENTÁRIO LITERÁRIO

\section{Ideias fundamentais}

Desenvolve-se, em primeiro lugar, nestes versos a ideia de ter sido Téspis o inventor da tragédia e de se ter seguido a este autor uma evolução muito variada do teatro grego, quer sob o aspecto propriamente literário, quer sob o dos recursos cénicos. Assim, Ésquilo inventaria a máscara e o manto trágico, seria o primeiro a fazer armar tablados e daria à tragédia um estilo elevado, condizente com a sua grandeza. Depois, viria a comédia com uma fase inicial, caracterizada por excessos de liberdade crítica, e uma fase posterior, em que esses excessos seriam reprimidos.

Em segundo lugar, exprime-se a ideia de que os poetas latinos não só não deixaram por tentar nenhum dos géneros dramáticos, como até souberam, seguindo o exemplo dos Gregos, acolher nos seus dramas factos e figuras nacionais. Daí dois tipos de peças: a fabula 
praetexta, ou praetextata, que versava de forma mais solene, com todo o aparato trágico, a lenda ou a história de Roma, e que foi cultivada, entre outros, por Névio, Pacúvio, Ácio; e a fabula togata, que se ocupava, de forma cómica, de assuntos da vida romana, e que teve como cultores, além do citado Névio, os poetas Titínio e Afrânio.

Note-se que as designações praetexta, ou praetextata, e togata derivam dos nomes das vestes envergadas pelos actores, isto é, a toga praetexta e a toga simples, vestuário nacional romano.

Quanto à tragédia e comédia romanas de assunto grego, Horácio não thes faz qualquer referência. A primeira foi cultivada por Lívio Andronico e por Énio; a segunda, a que se dá o nome de fabula palliata, em virtude do manto grego ou pallium envergado pelos actores, foi cultivada por Plauto e por Terêncio. Estes não raro se serviram do processo da contaminatio, ou seja a condensação de duas ou mais peças gregas numa só peça latina, como sucedeu nos Adelfos de Terên-

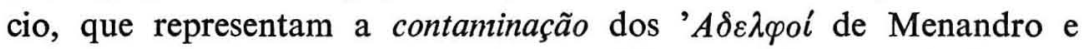
dos $\Sigma v v a \pi o \theta v \dot{\eta} \iota r o v \tau \varepsilon \varsigma$ de Dífilo, comédia que Plauto traduziu com o título de Commorientes.

No tocante aos factos gregos referidos antes, isto é, quanto ao que Horácio diz sobre a origem e evolução do teatro grego há várias observações a fazer:

(i) Quando Horácio alude à «acção dramática transportada em carros» (v. 276) e aos actores que neles seguiam «com os rostos besuntados de borras de vinho» (v. 277), incorre numa inexactidão. É que este facto diz respeito às origens da comédia, e não propriamente às peças de Téspis, apresentado aqui como inventor da «Camena trágica», isto é, da tragédia. Todavia, é de crer que o Poeta, neste como noutros casos, se fizesse eco de opinið̌es correntes no seu tempo.

(ii) As palavras successit uetus his comoedia (v. 281) reproduzem com precisão a realidade histórica: em primeiro lugar, porque entre Ésquilo e os primeiros comediógrafos não há, por assim dizer, intervalo; e em segundo lugar, porque a comédia, género com uma origem e evolução próprias, não é de modo algum desenvolvimento ou prolongamento da tragédia, como poderia à primeira vista depreender-se desta sucessão apresentada por Horácio: Téspis, Ésquilo, comédia 
antiga. No entanto, é possível que Horácio tenha escrito sob a ideia de que a plena florescência da tragédia foi realmente anterior ao período mais importante da comédia. E se assim pensou, teve razão.

(iii) Horácio manifesta neste passo a noção errónea que tem geralmente dos géneros poéticos. Considera Téspis como inventor da tragédia, da mesma forma que considera Arquíloco inventor da poesia iâmbica (v. 79) e tal como está convencido de que também a elegia teria tido o seu inventor, embora não saiba ao certo qual, visto que a este respeito "os gramáticos discutem e o processo está ainda pendente»: grammatici certant et adhuc sub iudice lis est (v. 78).

No caso da tragédia, como no caso da comédia ou de outro qualquer género literário, não pode actualmente manter-se a ideia de um simples inventor individual, de um criador a partir do nada, a quem a tradição apresenta como inventores; eles não foram mais, quase sempre, do que autores que, em certas épocas, pela força do seu génio e mercê da sua capacidade de condensar elementos artísticos dispersos, souberam dar expressão própria e individualidade definitiva a certos géneros literários. Mas o que é certo é que a Antiguidade via nesses autores verdadeiros inventores, verdadeiros criadores de géneros, e Horácio não podia, evidentemente, afastar-se da concepção antiga.

(iv) Apesar dos deslizes apontados, os vv. 275-294 da Arte Poética ficaram como uma síntese curiosa e expressiva da história do teatro greco-latino, pois, embora em esboço rápido, encontramos neles, expressos ou sugeridos, quase todos os vultos capitais e factos principais dessa história.

\section{Ideias acessórias}

Em complemento do que nos diz sobre o teatro romano; caracteristicamente nacional, Horácio afirma que o latim, isto é, a literatura latina, e mais propriamente a poesia, poderão competir em prestígio com a virtude e com os feitos das armas romanas, se ao poeta não 
faltarem o cuidado e o anseio de perfeição. Este conceito apresenta, evidentemente, algum exagero, sobretudo quando se pensa que o Poeta escreveu aqueles versos memoráveis da Epístola I, do livro II:

Graecia capta ferum uictorem cepit et artes intulit agresti Latio; sic horridus ille defluxit numerus Saturnius, et graue uirus munditiae pepulere; sed in longum tamem aeuum manserunt hodieque manent uestigia ruris.

(vv. 156-160)

«A Grécia conquistada conquistou o seu feroz vencedor e levou as artes ao rústico Lácio; assim caiu no esquecimento o grosseiro metro satúrnio, e a elegância expulsou a aspereza de um gosto rude. Contudo, mantiveram-se muito tempo e ainda hoje nos restam vestígios de rusticidade.»

Estas palavras nada mais fazem do que ecoar aqueloutras que, já antes, Cícero pronunciara publicamente ao defender o poeta Árquias (vide p. 340).

Contudo, Horácio, no seu íntimo, devia estar convencido de que a poesia romana nunca lograria alcançar a perfeição grega, quaisquer que fossem a aplicação e o esmero dos poetas latinos. Mas o seu exagero desculpa-se não só com o seu amor pátrio, mas também com a intenção didáctica da Arte Poética. A idealização de uma literatura latina, que equiparasse a grega, mercê da lima e da perseverança, serve para inculcar nos Pisões, a quem a obra era dirigida, o amor de uma arte séria, fortalecida pelo exercício, e o consequente desamor pela ligeireza e improvisão. É com o mesmo fim que o Poeta mais adiante dará a Lúcio Pisão um conselho célebre: nunca haja pressa em publicar o que porventura se tenha escrito; primeiro, é submeter a obra à apreciação de críticos de confiança, depois, é guardá-la anos a fio na gaveta. É que poder-se-á destruir em qualquer altura o que 
nunca se tiver publicado; uma palavra, uma vez lançada ao vento, não saberá voltar para trás (vide vv. 385-390).

É ainda com o mesmo desígnio que Horácio responderá a uma questão de palpitante interesse no seu tempo: «é o dom natural ou a arte que fazem os poemas dignos de louvor?» (v. 408). Pronunciando-se abertamente pela aliança dos dois valores, Horácio defende a conjugação harmoniosa do talento do poeta com a sua formação artística e a prática necessárias: «a meu ver, de nada vale o trabalho sem uma rica veia, ou o talento em estado bruto; ambos requerem o auxílio mútuo e conspiram em cordial união.» (vv. 409-411). É com estes mesmos conceitos, também, que Cícero deu início à defesa do poeta Árquias (vide p. 12): para o orador, como para o poeta, são imprescindíveis uma forte aliança do talento natural com a prática alcançada e a cultura adquirida (vide C. A. Louro FonseCA, Defesa de Árquias in Cícero. Lisboa, Verbo, 1974, pp. 178-179). Quer isto dizer que não existe arte poética, por mais genial que seja, que possa desprender-se da cultura e do exercício (vd. pp. 342-344).

\section{Alguns pormenores}

(i) Horácio, ao referir-se à comédia grega, alude genericamente, como já vimos, a duas fases: uma é chamada Comédia Antiga, aquela que se caracteriza principalmente pela sátira pessoal e política e que tem o seu mais celebrado representante em Aristófanes; a outra é toda a comédia posterior, em que «a lei foi aceite, e o coro passou pela vergonha de se calar, uma vez sem direito de fazer mal.» (vv. 283-284), e que acabou por se tornar em comédia de costumes. Contudo, importa observar o que Horácio não nos diz explicitamente: é que à Comédia Antiga não se segue propriamente um só período, mas dois, geralmente admitidos pelos historiadores da literatura grega. São eles o da Comédia Média e o da Comédia Nova.

A Comédia Média representa um período de transição entre a comédia de ataque pessoal e político, e a comédia de costumes, e teve como principais representantes Antífanes, Aléxis e, talvez, o próprio Aristófanes na sua comédia Pluto. A Comédia Nova está principalmente representada por Menandro. 
(ii) Poderá perguntar-se, a propósito da citação do poeta Ésquilo, no v. 279 , porque é que não são também nomeados os outros dois tragediógrafos mais representativos: Sófocles e Eurípides.

Em princípio, a explicação deste pormenor pode estar no facto de não ter havido, depois de Ésquilo, inovações fundamentais na tragédia. Além disso, há também a considerar que Horácio só quis dar aos Pisões uma brevíssima síntese da história do teatro grego. O nome de Ésquilo, pelo seu extraordinário prestígio, chegaria bem para resumir a longa galeria dos trágicos atenienses. Mas nunca Horácio iria além de Sófocles, mesmo que não citasse o nome de Ésquilo. É que a poesia de Eurípides, ao contrário da de Ésquilo e da de Sófocles, não podia constituir para Horácio um padrão de poesia clássica, por lhe faltar uma virtude classicamente essencial: o equilibrio estético. Ora o autor da Arte Poética, como bem clássico, não podia ser insensível a este desequilíbrio, que os antigos muito bem notaram e que explicará, em grande parte, a falta de êxito da tragédia euripidiana no seu tempo. Nesta mesma ordem de ideias, compreende-se também que Horácio, noutro lugar onde se refere à tragédia e em que cita vários nomes, igualmente deixe em silêncio o nome de Eurípides. 
(Página deixada propositadamente em branco) 
I. HEXÂMETRO: como o nome indica, é um verso de 6 pés.

a) HEX. DACTílico: os 4 primeiros pés podem ser dáctilos ( $-\cup \cup)$ ou espondeus (- -); o quinto pé é obrigatoriamente dáctilo; o sexto, espondeu ou troqueu (- - : note que a última sílaba de qualquer verso tem quantidade ancípite, isto é, tanto pode ser longa como breve):

$-x u-x u|-x v|-x|-u v|-x$

Exemplos:

Labitur uncta carina, uolat super impetus undas.

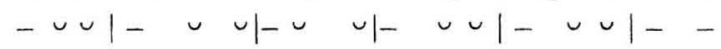

(Énio, Annales)

Percellunt magnas quercus, exciditur ilex.

$--1-\quad-1-\quad-1--1-v \cup \mid--$

(id., ibid.)

Musae quae pedibus magnum pulsatis Olympum.

$-\quad|-u v|-\quad-|-\quad-|-\cup u \mid-$

(id., ibid.)

N.B.: Para outros exemplos, vd. pp. 311, 313, 340, $384-385,389,393-394$ e 397.

b) HEX. ESPONDAICO: mais raro que o hexâmetro dactílico, apresenta, como única diferença, um espondeu no quinto pé:

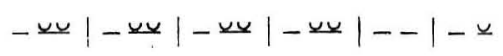

Exemplos:

Olli respondit rex Albai Longai

$--1--1--1--1--1--$

(Énio, Annales) 
Tene Thetis tenuit pulcherrima Nereine?

$-\sim v|-\cup u|--1-\cup \cup|--|--$

(Catulo, 64, v. 28)

II. DÍSTICO ELEGÍACO: constituído por um hexâmetro (geralmente dactílico) e um pentâmetro (também chamado elegíaco):

$-u|-u|-u|-u|-u \mid-v$

$-u|-u v|-||-u|-u v| x$

N.B.: O primeiro hemistíquio do pentâmetro é constituído por dois pés, dáctilos ou espondeus, e uma sílaba longa a que se segue uma pausa obrigatória (cesura); o segundo hemistíquio apresenta dois dáctilos não substituíveis e uma sílaba final ancípite (vd. supra, hexâmetro dactílico).

Exemplo:

Sed quamquam me nocte premunt uestigia diuum

$-\quad-1-\quad-|-u-u|-\quad-|-v u|-v$

lux autem canae Tethyi restituit

$--|-\quad-|-||-u v|-u v| v$

(Catulo, 66, vv. 69-70)

N.B.: Para outros exemplos, vd. Catulo, Carmina, 70, 72, 83 (p. 366), 92, 85, 87 (p. 368), 100 (p. 372).

III. HENDECASSÍLABO FALÉCIO: como o nome indica, é um verso de onze sílabas métricas:

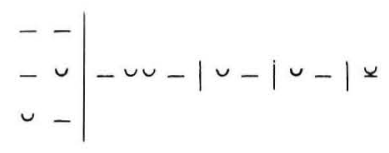

N.B.: O primeiro pé pode ser constituído por um espondeu ou um troqueu ou um iambo ( $\left.v_{-}\right)$; o segundo é formado por um coriambo (- $\left.\cup_{-}\right)$a que se seguem dois iambos e uma sílaba final ancípite (vd. supra, hexâmetro dactílico). 
Exemplos:

Passer, deliciae meae puellae

$--|-v u-| v-|v-|-$

(Catulo, 2, v. 1)

et acris solet incitare morsus

$u-|-u v-| u-\mid u-1-$

(id., ibid., v. 4)

N. B.: Para outros exemplos, vd. Catulo, Carmina, 49 (p. 238), 5 (p. 364), 58 (p. 368), 13 e 46 (p. 370),

IMPORTANTE:

1. Quando a uma palavra terminada por vogal se lhe segue uma outra começada igualmente por vogal ou $h$, a primeira dessas vogais elide-se (sinalefa).

2. Quando a uma palavra terminada por $m$ se lhe segue uma outra começada por vogal ou $h$, o $m$ (que tinha nesta posição uma pronúncia muito débil) cai e a primeira das vogais em contacto elide-se (ectlipse):

Exemplos:

multa quoque et bello passus, dum conderet urbem

$-\sim \cup \mid--1--1-\quad-1-u v 1-u$

- (Virgílio, Eneida, I, v. 5)

Lesbia formosa est, quae cum pulcherrima tota est,

$-u v 1--1$ - $-1--1-u v 1--$

tum omnibus una omnis subripuit ueneres.

$-v v|--1-| 1-v v|-v v|-$

(Catulo, 86, vv. 5-6)

Lugete, o Veneres Cupidinesque,

$--1-u v-1 \cup-\mid v-1 u$

et quantumest hominum uenustiorum.

$-\quad-1 \quad \sim \sim-1 \cup-|v-| v$

(id., 3, vv. 1-2) 
3. Uma vogal etimologicamente breve seguida de duas consoantes, a segunda das quais é uma líquida $(l, n$ ou $r$ ), tem quantidade ancípite (vd. p. 401, alínea $a$ ).

Assim, no hexâmetro seguinte, a sílaba -lu- (de uolucri e uolucris) é contada primeiramente como breve e depois como longa:

et primum similis uólucri; mox uera uolúcris.

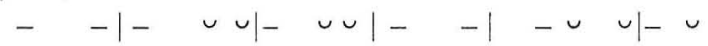

Outros exemplos:

Nimborum in patriam, loca feta furentibus Austris

(Virgílio, Eneida, I, v. 51)

Natum ante ora patris, patrem qui obtruncat ad aras

$\smile_{-1}^{-} \smile_{-} \cup\left|--1-\smile_{-1}-\cup \cup\right|--$

(id., ibid., II, v. 663)

Tum uitulus, bima curuans iam cornua fronte.

$-\sim u|-\quad-|-\quad-|-\quad-|-u v \mid-u$

(id., Geórgicas, IV, 299)

EXERCÍCIOS.

Escanda os seguintes hexâmetros dactílicos:

Albanique patres atque altae moenia Romae

(id., Eneida, I, v. 7)

Africus et uastos uoluunt ad littora fluctus.

(id., ibid., I, v. 86)

Ingemit, et duplices tendens ad sidera palmas

(id., ibid., I, v. 93)

Talia iactanti, stridens Aquilone procella

(id., ibid., I, v. 102)

Disiectam Aeneae toto uidt aequore classem

(id., ibid., I, v. 128)

Nec latuere doli fratrem Iunonis et irae

(id., ibid., I, v. 130)

Tum, pietate grauem ac meritis si forte uirum quem

(id., ibid., I, v. 151) 


\section{N D I C E}

Págs.

Prefácio da $1 .^{a}$ edição . . . . . . . . . . . . . . . . . . . . . . . . . . 3

Prefácio da $4 .^{a}$ edição . . . . . . . . . . . . . . . . . . . . . . . . 5

Agradecimento . . . . . . . . . . . . . . . . . . . . . . . . 6

\section{PAR TE}

Introdução: a pronúncia restaurada do latim . . . . . . . . . . . . . 9

Exercício de leitura . . . . . . . . . . . . . . . . . . . . . 12

Acentuação . . . . . . . . . . . . . . . . . . . . . . . . . . . . 13

Exercício de leitura: Imperium Romanum . . . . . . . . . 14

PRIMEIRA DECLINAÇÃO . . . . . . . . . . . . . . . . . . 14

Adjectivos no feminino . . . . . . . . . . . . 16

Função dos casos . . . . . . . . . . . . . . . . . . . . . . . . . 17

Exercícios . . . . . . . . . . . . . 18

Ordem das palavras na frase latina . . . . . . . . . . . . . . . . 22

Lusitania, patria nostra . . . . . . . . . . . . . 22

Vita rustica.................. . . . 23

COMPLEMENTOS DE LUGAR . . . . . . . . . . . . . . . . . 24

Vrbs Roma . . . . . . . . . . . . . . . 28

Recitação: Pastorela . . . . . . . . . . . . . . . 31

Verbo ESSE: pres. do ind. . . . . . . . . . . . . . . . . . . . . . 32

pret. imp. do ind. . . . . . . . . . . . . . . . . . . . 32

Exercícios de aplicação . . . . . . . . . . . . . . . 33 
Conjugação verbal: pres do ind. . . . . . . . . . . . . . . . . . . . 34

Paulae in uilla .................. . . . . 36

AGENTE DA PASSIVA . . . . . . . . . . . . . . . . . . . . . 38

Exercícios . . . . . . . . . . . . . . . . . . . . . 39

Exercícios sobre o acusativo . . . . . . . . . . . . . . . . . . . 41

Preposições de acusativo . . . . . . . . . . . . . . . . . 42

Exercícios sobre o ablativo . . . . . . . . . . . . . . . . . . . . . 44

Preposições de ablativo . . . . . . . . . . . . . . . . . 45

SEGUNDA DECLINAÇÃo . . . . . . . . . . . . . . . . . . . 46

Adjectivos da primeira classe . . . . . . . . . . . . . . . . 47

DECLINAÇÃo PRONOMINAL: I. Possessivos . . . . . . . . . . 54

Claudius Romam aduenit . . . . . . . . . . 54

Domus Romana . . . . . . . . . . . . . . 58

A família romana ............... 60

DECLINAÇÃO PRONOMINAL:

II. Demonstrativos . . . . . . . . . . . . . . . . . 64

III. Adjectivos pronominais . . . . . . . . . . . . . . . . . 67

Lucii nutrix fabulam mirabilem narrat .......... 67

ORAÇÕES INTERROGATIVAS DIRECTAS . . . . . . . . . . . . 69

. Conjugação verbal: pret. imp. do ind. . . . . . . . . . . . . . . . . 74

Recitação: Carpe diem . . . . . . . . . . . . 75

Lauatio inuita . . . . . . . . . . . 76

Como exprimir a posse . . . . . . . . . . . . . . . . . . . . 77

Exercícios . . . . . . . . . . . . . . . . . . . . . . . 8

Pullus ad margaritam ................. 82

CONCRETISMO E SEMÂNTICA . . . . . . . . . . . . . . . . . 83

Dei Romani ................. . . 86 
QUINTA DECLINAÇÃO . . . . . . . . . . . . . . . . 91

Exercícios . . . . . . . . . . . . . . . . . . . . . . . . . 92

Hebdomadae dierum nomina .............. 93

Conjugação verbal: fut. imperfeito . . . . . . . . . . . . . . . . . . 95

Exercícios . . . . . . . . . . . . . . . . . . . . 96

Recitação: Omnia uanitas . . . . . . . . . . . . . . . . . . . . . . 97

TERCEIRA DECLINAÇÃO: temas em consoante . . . . . . . . . . 98

De Ioue . . . . . . . . . . . . . . . . . . . 102

TERCEIRA DECLINAÇÃO (cont.): temas em -i ......... . . 103

De Iouis pueritia . . . . . . . . . . . . . . . 106

DECLINAÇÃo PRONOMINAL: IV. a) Pronome relativo; b) Pronome interrogativo; c) Pronomes indefinidos ... . . . . . 107

luppiter Saturnum e regno pellit . . . . . . . . . . . 111

TERCEIRA DECLINAÇÃO (cont.): neutros . . . . . . . . . . . . 112

Observações à terceira declinação. . . . . . . . . . . . . . . . 114

De aurea aetate . . . . . . . . . . . . . . . . 116

DECLINAÇÃo PRONOMINAL: V. Pronomes pessoais . . . . . . 118

Exercícios de revisão:

I. In foro . . . . . . . . . . . . . . . . . . . . . 119

II. Apud Antonium :

a) In atrio . . . . . . . . . . . . . . . . . . . 121

b) In tablino . . . . . . . . . . . . . . . . . 122

c) In triclinio . . . . . . . . . . . . . . . . . . . . 124

Versões para latim . . . . . . . . . . . . . . . . . . . . 128

Thermae: . . . . . . . . . . . . . . 131

I. In palaestra . . . . . . . . . . . . . . . . . . . . . . . 131

II. In apodyterio . . . . . . . . . . . . . . . . . . 132

Versão para latim . . . . . . . . . . . . . . . . . . . 135

In theatro . . . . . . . . . . . . 136

Versão para latim. . . . . . . . . . . . . . . . . . . 139 
Adjectivos da segunda classe

De mulieribus a Ioue amatis:

1. De Europae raptu . . . . . . . . . . . . . . . . . . . 144

2. De Alcmena, Herculis matre . . . . . . . . . . . . . . 144

3. De Ioue, in formam cycni mutato, et Leda . . . . . . . 145

Compostos de ESSE . . . . . . . . . . . . . . . . . . . . . . . . . . . . . 149

Sintaxe dos compostos de ESSE . . . . . . . . . . . . . . . . . . . 149

QUARTA DECLINAÇÃO . . . . . . . . . . . . . . . . . . . . . . . . 151

Recitação: In taberna quando sumus . . . . . . . . . . . . . . 153

Conjugação verbal: pret. perf. do ind. . . . . . . . . . . . . . . . . 154

De Ganymedis raptu:

1. Ganymedes, deorum pincerna . . . . . . . . . . . . 157

2. Iuno, zelotypa uxor . . . . . . . . . . . . . . . 157

Conjugação verbal: pret. m.-q.-perf. do ind. . . . . . . . . . . . . . . 160

ABLATIVO ABSOLUTO OU ORACIONAL . . . . . . . . . . . 162

Exercícios . . . . . . . . . . . . . . . . . . . . . . . . 163

A expressão casar com . . . . . . . . . . . . . . . . . . . . . . . . . 168

Exercícios . . . . . . . . . . . . . . . . . . . . . . . . 169

BELLVM TROIANVM AB OVO NARRATVR:

I - De Paride, Priami et Hecubae filio . . . . . . . . . . 171

II - Dc Pelei Thetidisque nuptiis ac Discordiae pomo . . . . 171

III - De Paridis iudicio . . . . . . . . . . . . . . . . . . 172

IV - De Paridis agnitione . . . . . . . . . . . . . . . 172

V - De Helenae, Menelai uxoris, raptu . . . . . . . . . . 173

VI - De Iphigenia . . . . . . . . . . . . . . . 173

Sintaxe de ESSE . . . . . . . . . . . . . . . . . . . . . . . . . . . . . . . . 180

Exercícios . . . . . . . . . . . . . . . . . . . . . . . . . . 182

GRAUS DOS ADJECTIVOS: comparativos . . . . . . . . . . . . 184

Exercícios de aplicação . . . . . . . . . . . . . . . . . . . . . . . . 186

Liberi, pulcherrima matris ornamenta . . . . . . . . . . . . . 190 
Conjugação verbal: fut. perfeito . . . . . . . . . . . . . . . . . . . . 191

Ficus de qua se suspendebant mulieres . . . . . . . . . . . . . 193

Conjugação verbal:

pres. do conjuntivo . . . . . . . . . . . . . . . . . . . . . . . . 194

pret. imp. do conjuntivo. . . . . . . . . . . . . . . . . 195

BELLVM TROIANVM AB OVO NARRATVR (cont.):

VII - De Graecorum dolo . . . . . . . . . . . . . . . 197

VIII - De Troianis deceptis . . . . . . . . . . . . . . 198

IX - De Laocoonte . . . . . . . . . . . . . . . . . . . 198

X - De Laocoontis filiorumque morte . . . . . . . . 199

Conjugação verbal:

pret. perf. do conjuntivo. . . . . . . . . . . . . . . . . . 204

pret. m.-q.-p. do conjuntivo . . . . . . . . . . . . . . . . 206

De Arria, matre animosa . . . . . . . . . . 208

Conjugação verbal:

imperativo presente . . . . . . . . . . . . . . . . . . . . 210

infinitivo presente. . . . . . . . . . . . . . . . 210

infinitivo perfeito . . . . . . . . . . . . . . . . . 211

ORAÇÖES INFINITIVAS . . . . . . . . . . . . . . . . . . . . 212

Exercícios . . . . . . . . . . . . . . . . . . 215

BELLVM TROIANVM AB OVO NARRATVR (cont.):

$\mathrm{XI}$ - Equus Troiam inuehitur . . . . . . . . . 220

XII - Troiae tandem Graeci! . . . . . . . . . . . . 221

XIII - Acneae somnium . . . . . . . . . . . 221

XIV - Troiae suprema dies . . . . . . . . . . . 222

GRAUS DOS ADJECTIVOS: superlativos . . . . . . . . . . 228

Como traduzir o superlativo absoluto. . . . . . . . . . . . . . 229

De uxore Socratis philosophi ................ 231

Advérbios de modo . . . . . . . . . . . . . . . . . . . . . . 232

A cultura e a religiosidade de Carlos Magno . . . . . . . . 232 
Conjugação verbal:

Pàds.

participio presente . . . . . . . . . . . . . . . . . . . . . . . 234

participio futuro . . . . . . . . . . . . . . . . . . . . . . . 234

infinitivo futuro activo . . . . . . . . . . . . . . . . . . . . 234

gerúndio. . . . . . . . . . . . . . . . . . . 236

A Cícero . . . . . . . . . . . . . . . . . . . . . . 238

CONJUGAÇÃo PERIFRÁSTICA (voz activa) . . . . . . . . . . . . . 239

Exercícios . . . . . . . . . . . . . . . 240

De auspiciis . . . . . . . . . . . . 242

GRAUS DOS ADJECTIVOS: casos particulares . . . . . . . 243

Apelles ad sutorem . . . . . . . . . . . 245

Conjugação verbal:

Supino em -u . . . . . . . . . . . . . . . . . . . . 247

infinitivo futuro passivo . . . . . . . . . . . . . . . 247

gerundivo . . . . . . . . . . . . . . . . . . 248

CONJUGAÇÃo PERIFRÁSTICA (voz passiva) . . . . . . . . . . . 252

Exercícios ................ . . 253

Euripidès, poēta sibi cōnscius artis suae. . . . . . . . 258

ORAÇÕES INFINITIVAS (cont.) . . . . . . . . . . . . . . 260

Ranae regem ab Ioue petentes . . . . . . . . . . . 261

Conjugação verbal:

I-posse . . . . . . . . . . . . . . . . 263

II-ferre. . . . . . . . . . . . . . . . . . . . . 264

III - ire . . . . . . . . . . . . . . . . . . . . . . . . . 268

IV -uelle; nolle; malle . . . . . . . . . . . . . . . . . 270

V-fieri . . . . . . . . . . . . . . . . 274

Polus ille tragoedus. . . . . . . . . . . . . . 275

ORAÇÕES INTERROGATIVAS INDIRECTAS . . . . . . . . 277

Exercícios . . . . . . . . . . . . 278

Numerais cardinais e ordinais . . . . . . . . . . . . . . . . . 280 
TROIANI IN ITALIA:

Págs.

I - Aeneas in Italiam appellit . . . . . . . . . 285

II - De Romuli Remique pueritia . . . . . . . . . . . . . 286

III - Romulus Romae conditor . . . . . . . . . . . 287

SEPTEM ROMANORVM REGES; PRIMI CONSVLES; DICTATVRA 291

I - Sabinarum raptus et Romuli apotheosis . . . . . . . 291

II - Numa Pompilius, Tullus Hostilius et Ancus Marcius . . . 292

III - Priscus Tarquinius et Seruius Tullius . . . . . . . 293

IV - Lucius Tarquinius Superbus . . . . . . . . . 295

V-Primi consules . . . . . . . . . . . . . 296

VI - T. Larcius, dictator primus . . . . . . . . . . . . 297

\section{I PAR T E}

SOMNIVM SEV MIRIFICA NAVIGATIO: . . . . . . . . . . . . 307

ANTELOQUTVM ..................... . . . 309

I — Vbi de Homero loquitur . . . . . . . . . . . . . . 309

II - De nauigationis apparatu . . . . . . . . . 310

III - Nauigationis initium . . . . . . . . . . . . 311

IV — De diabolo qui malam mulierem duxit uxorem . . . . 312

V - Terribili procella iactati . . . . . . . . . 313

VI - In insula Bacchi . . . . . . . . . . . . . . . . . . 314

VII - Nauis uolans . . . . . . . . . . . . . . . . 316

VIII - Viri uulturibus uehentes . . . . . . . . . . . 317

IX - Lunatícus, Selenitarum rex . . . . . . . . . . 318

X - De speculo mirabili . . . . . . . . . . . . . 319

$\mathrm{XI}$ - In terram reditus .............. . . 320

XII - Cetum immanem adspicimus . . . . . . . . . 320

XIII - Cetus uiros ipsa cum naue haurit . . . . . . . . . 321

XIV - Intus in ceto . . . . . . . . . . . . 322 
Págs.

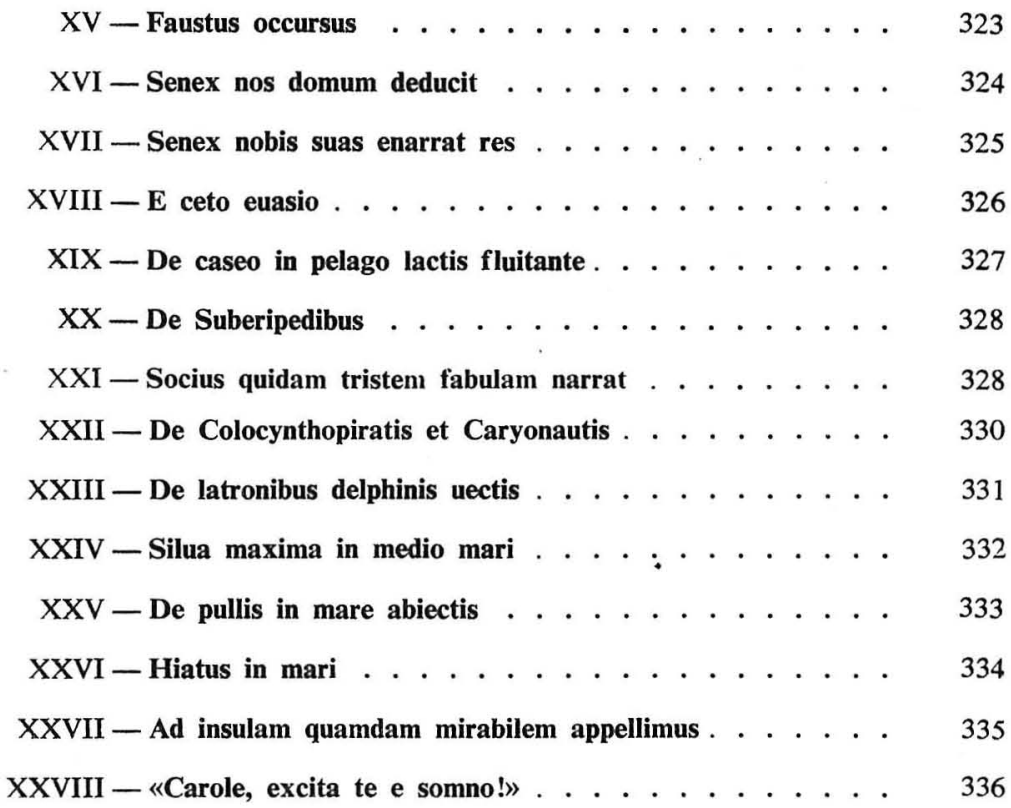

\section{I I PARTE}

CÍCERO: o elogio das letras e o conceito de glória

CATULO: breve antologia ................. . . 364

SALÚSTIO: um conceito de história . . . . . . . . . . . . . . . . 374

HORÁCIO: três temas de cultura:

I - A linguagem . . . . . . . . . . . . . . . 384

II - A epopeia . . . . . . . . . . . . . . . . . . . . . 389

III - O teatro . . . . . . . . . . . . . . . 393

NOÇÕES DE MÉTRICA LATINA . . . . . . . . . . . . . . . . 401

Índice . . . . . . . . . . . . . . 405 


\section{CENTRO DE ESTUdOS CLÁSSICOS E HUMANÍSTICOS}

FACULDADE DE LETRAS DE COIMBRA

Textos clássicos

1. Plauto, Anfitrião. Introdução, versão do latim e notas de Carlos Alberto LOURO FonseCA. 1978. 3. edição, 1988.

2. Plauto, $O$ Gorgulho. Introdução, versão do latim e notas de Walter DE Mederros. 1978. 3.^ edição, 1991.

3. ARISTÓfanes, As mulheres que celebram as Tesmofórias. Introdução. versão do grego e notas de MARIA de Fátima de Sousa E SiLVA. 1978. 2." edição, 1988.

4. Sófocles, Filoctetes. Introdução, versão do grego e notas de José RiBeiro FERREIRA. 1979. 2.a edição, 1988.

5. Sófocles, Rei Édipo. Introdução, versão do grego e notas de MARIA do Céu Zambujo Fialho. 1979. 2. a edição, 1986.

6. Eurf́pides, Hipólito. Introdução, versão do grego e notas de Bernardina de Sousa Oliverra. 1979.

7. Platão, Lísis. Introdução, versão do grego e notas de Francisco dE Oliverra. 1980.

8. Plauto, $O$ soldado fanfarrão. Introdução, versão do latim e notas de Carlos Alberto Louro Fonseca. 1980. 2.a edição, 1987.

9. Aristófanes, Os Acarnenses. Introdução, versão do grego e notas de Maria de FÁtima de Sousa e Silva. 1980. 2.a edição, 1988.

10. Plauto, Epídico. Introdução, versão do latim e notas de WALTER DE MedeIros. 1980. 2.a edição, 1988.

11. Aristófanes, Pluto. Introdução, versão do grego e notas de Américo da Costa Ramalho. 1982. 2." edição, 1989.

12. Platão, Cármides. Introdução, versão do grego e notas de Francisco DE OLIVEIRA. 1981. 2. a edição, 1988.

13. EuRf́pIDEs, Orestes. Introdução, versão do grego e notas de AugusTa Fernanda de Oliveira e Silva. 1982.

14. TerÊnCio, Os dois irmãos. Introdução, versão do latim e notas de WALter DE MedeIros. 1983. 2.8 edição, 1988.

15. Platão, Fédon. Introdução, versão do grego e notas de Maria Teresa SChIAPPA DE AZEVEDo. 1983.

16. Plauto, Os dois Menecmos. Introdução, versão do latim e notas de Carlos Alberto louro Fonseca. 1983. 2.a edição, 1989.

17. Aristófanes, A Paz. Introdução, versão do grego e notas de Maria DE FÁtrma de Sousa E Silva. 1984. 2.a edição, 1989.

18. SófoCles, As Traquinias. Introdução, versão do grego e notas de MARIA do Céu Zambujo Fialho. 1984. 2."a edição, 1989. 
19. Sófocles, Antigona. Introdução, versão do grego e notas de MARIA Helena da Rocha Pereira. 1984. 2. edição, 1987. 3.a edição, 1992.

20. Platão, Apologia de Sócrates. Críton. Introdução, versão do grego e notas de Manuel de Oliveira Pulquério. 1984. 2.a edição, 1990.

21. Platão, Hipias Maior. Introdução, versão do grego e notas de Maria Teresa Schiappa de Azevedo. 1985. 2. a edição, 1989.

22. Plauto, A comédia da marmita. Introdução, versão do latim e notas de WAlter de Medeiros. 1985. 2.a edição, 1989.

23. AviENo, Orla maritima. Introdução, versão do latim e notas de José RIBEIro Ferreira. 1985. 2.a edição, 1992.

24. ARISTófanes, Os Cavaleiros. Introdução, versão do grego e notas de MARIA de Fátima de Sousa e Silva. 1985. 2.a edição, 1991.

25. ÉsQuilo, Agamémnon. Introdução, versão do grego e notas de MANUEL de Oltveira Pulquério. 1985.

26. TerênCIO, A sogra. Introdução, versão do latim e notas de WALTER DE Medeiros. 1987.

27. Platão, Laques. Introdução, versão do grego e notas de Francisco DE Oliveira. 1987.

28. ARISTófanes, As mulheres no Parlamento. Introdução, versão do grego e notas de Maria de Fátima de Sousa e Silva. 1988.

29. Terêncio, A moça que veio de Andros. Introdução, versão do latim e notas de Walter de Medeiros. 1988.

30. Menandro, $O$ díscolo. Introdução, versão do grego e notas de Maria de Fátima de Sousa e Silva. 1989.

31. LuCiano, Diálogo dos mortos. Introdução, versão do grego e notas de Américo da Costa Ramalho. 1989.

32. Platão, Hípias Menor. Introdução, versão do grego e notas de Maria Teresa Schiappa de Azevedo. 1990.

33. EuRípIDEs, Medeia. Introdução, versão do grego e notas de MARIA Helena da Rocha Pereira. 1991.

34. Ésquilo, Persas. Introdução, versão do grego e notas de MANUEL de Oliveira Pulquério. 1992. 
Textos do Humanismo Renascentista em Portugal

1. Carlos Ascenso ANDré, Diogo Pires-Antologia poética. Introdução, tradução, comentário e notas. 1983.

2. AMÉRICo DA Costa Ramalho, Latim renascentista em Portugal. Introdução, selecção, versão do latim, comentário e notas. 1985.

3. Isaltina das Dores Figueiredo Martins, Bibliografia do Humanismo em Portugal no século XVI. 1986.

4. Sebastião Tavares de Pinho, Lopo Serrão e o seu poema "Da velhice». Estudo introdutório, texto latino e aparato crítico, tradução e notas. 1987.

5. Virginia Soares Pereira, André de Resende-Carta a Bartolomeu de Quevedo. Introdução, texto latino, versão e notas. 1988.

6. Américo da Costa Ramalho, Para a história do Humanismo em Portugal - I. 1988.

7. Albino de Almeida Matos, A Oração de Sapiência de Hilário Moreira. 1990.

8. Mario Santoro, Amato Lusitano ed Ancona. 1990.

9. Belmiro Fernandes Pereira, As Orações de Obediência de Aquiles Estaço. 1991.

10. Carlos Ascenso André, Um Judeu no Desterro, Diogo Pires e a memória de Portugal. 1992.

Estudos de Cultura Clássica

1. Manuel de Oliveira Pulquério, Problemática da tragédia sofocliana. 21987.

2. Maria de Fátima Sousa e Silva, Critica do teatro na comédia antiga. 1987.

3. José Ribeiro Ferreira, $O$ drama de Filoctetes. 1989.

4. Carlos Morais, Expectativa e movimento no "Filoctetes". 1991.

5. Francisco de Oliveira, Les Idées Politiques et Morales de Pline l'Ancien. 1992.

6. Maria do Céu Zambujo Fialho, Luz e Trevas no Teatro de Sófocles. 1992. 


\section{INSTITUTO DE ESTUDOS CLÁSSICOS \\ FACULDADE DE LETRAS DE COIMBRA}

A. Costa Ramalho e J. Castro Nunes - Catálogo dos manuscritos da Biblioteca-Geral da Universidade de Coimbra, relativos à Antiguidade Clássica. 1945.

Jorge Alves Osório - M.• João Fernandes - A Oração sobre a Fama da Universidade (1548). Prefácio, introdução, tradução e notas. 1967.

ana Paula Quintela F. Sottomayor-Ésquilo: As Suplicantes. Introdução, tradução do grego e notas. 1968.

Cataldo Parísio Sículo - Martinho Verdadeiro Salomão. Prólogo, tradução e notas de Dulce DA C. Vieira. Introdução e revisão de Américo DA Costa RAMALHO. 1974.

M. Helena da Rocha Pereira - Poesia grega arcaica. 1980.

M. Helena da Rocha Pereira - Hélade. Antologia da cultura grega. 4..$^{3}$ edição, 1982.

M. Helena da Rocha Pereira - Romana. Antologia da cultura romana. 21986.

Francisco de Oliveira - Ideias morais e politicas em Plínio o Antigo. 1986.

Carlos Alberto Louro Fonseca - Sic itur in Vrbem. Iniciaşão ao latim. 61991.

Carlos Alberto louro Fonseca - Iniciação ao grego. 21987.

\section{CENTRO DE ESTUDOS CLÁSSICOS E HUMANÍSTICOS}

FACULDADE DE LETRAS DE COIMBRA

J. Geraldes Freire - A versão latina por Pascásio de Dume dos «Apophthegmata Patrum». 2 vols. 1971.

J. RibeIro Ferreira - Euripides: Andrómaca. Introdução, tradução do grego e notas. 1971.

J. Geraldes FreIRE - Commonitiones Sanctorum Patrum. Uma nova coleç̧ão de apotegmas. Estudo filológico. Texto crítico. 1974.

Cataldo Parísio Sículo - Duas orações. Prólogo, tradução e notas de MARIA MARGARIDA BRANDÃo Gomes DA Silva. Introdução e revisão de Américo da Costa Ramalho. 1974.

C. A. Pais De AlmeidA-Eurípides: Ifigénia em Aulide. Introdução e tradução do grego. 1974.

M. SANtos Alves - Euripides: As Fenícias. Introdução, tradução do grego e notas. 1975.

M. DE FÁtima de Sousa E Silva - Menandro: $O$ discolo. Introdução, tradução do grego e notas. 1976.

Nair de Nazaré Castro Soares - Diogo de Teive - Tragédia do Príncipe João, 1977.

Américo DA Costa RAMALHo - Estudos camonianos. 21980. 
(Página deixada propositadamente em branco) 
SÉRIE ENSINO

IMPRENSA DA UNIVERSIDADE DE COIMBRA

COIMBRA UNIVERSITY PRESS

2012

- $\mathrm{U}$

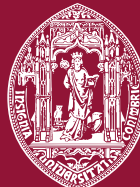

C •

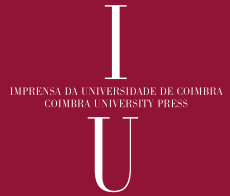

